Nevada

Environmental

Restoration

Project

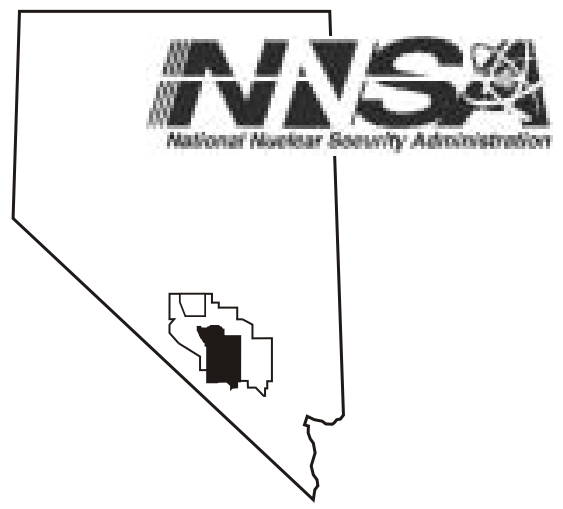

Closure Report for Corrective

Action Unit 262: Area 25 Septic

Systems and Underground

Discharge Point, Nevada Test Site, Nevada

Controlled Copy No.:

Revision: 1

July 2003

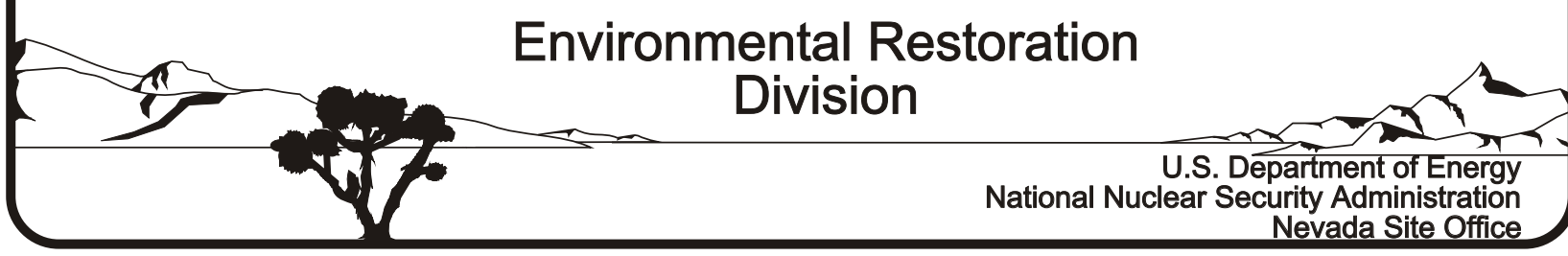




\section{DISCLAIMER STATEMENT}

Reference herein to any specific commercial product, process, or service by trade name, trademark, manufacturer, or otherwise, does not necessarily constitute or imply its endorsement, recommendation, or favoring by the U.S. Government or any agency thereof or its contractors or subcontractors.

\section{AVAILABILITY STATEMENT}

Available for sale to the public from-

U.S. Department of Commerce

National Technical Information Service

5285 Port Royal Road

Springfield, VA 22161-0002

Telephone: 800.553 .6847

Fax: 703.605.6900

E-mail: orders@ntis.gov

Online ordering: http://www.ntis.gov/ordering.htm

Available electronically at http://www.osti.gov/bridge

Available for a processing fee to U.S. Department of Energy and its contractors, in paper, from-

U.S. Department of Energy

Office of Scientific and Technical Information

P.O. Box 62

Oak Ridge, TN 37831-0062

Telephone: 865.576 .8401

Fax: 865.576.5728

E-mail: reports@adonis.osti.gov 


\title{
CLOSURE REPORT \\ FOR CORRECTIVE ACTION UNIT 262: \\ AREA 25 SEPTIC SYSTEMS \\ AND \\ UNDERGROUND DISCHARGE POINT, \\ NEVADA TEST SITE, NEVADA
}

\author{
Prepared for: \\ U.S. Department of Energy \\ National Nuclear Security Administration \\ Nevada Site Office \\ Work Performed Under Contract No. DE-AC 08-96NV11718
}

Controlled Copy No.

Revision: 1

July 2003 
THIS PAGE INTENTIONALLY LEFT BLANK 


\section{CLOSURE REPORT FOR CORRECTIVE ACTION UNIT 262: AREA 25 SEPTIC SYSTEMS AND UNDERGROUND DISCHARGE POINT, NEVADA TEST SITE, NEVADA}

Approved by: SIGNATURE APPROVED

Janet Appenzeller-Wing, Project Manager Industrial Sites Project

Approved by: SIGNATURE APPROVED

Runore C. Wycoff, Director

Environmental Restoration Division
Date: $7 / 3 / 2003$

Date: $\underline{7 / 3 / 2003}$ 
THIS PAGE INTENTIONALLY LEFT BLANK 


\section{TABLE OF CONTENTS}

ACRONYMS AND ABBREVIATIONS $\ldots \ldots \ldots \ldots \ldots \ldots \ldots \ldots \ldots \ldots \ldots$ ix

EXECUTIVE SUMMARY $\ldots \ldots \ldots \ldots \ldots \ldots \ldots \ldots \ldots \ldots \ldots \ldots \ldots \ldots \ldots \ldots$

$1.0 \quad$ INTRODUCTION $\ldots \ldots \ldots \ldots \ldots \ldots \ldots \ldots \ldots \ldots \ldots \ldots \ldots \ldots \ldots \ldots \ldots$

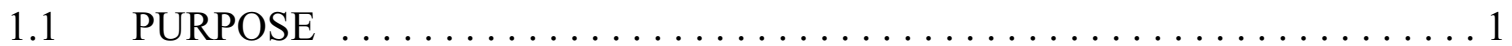

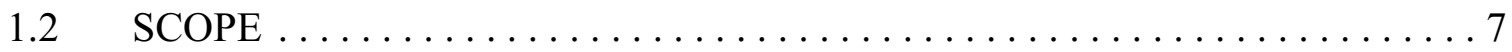

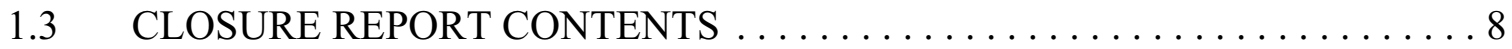

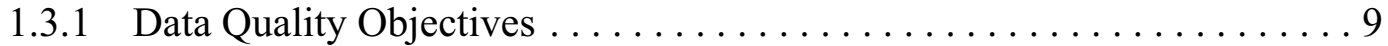

2.0 CLOSURE ACTIVITIES $\ldots \ldots \ldots \ldots \ldots \ldots \ldots \ldots \ldots \ldots \ldots \ldots \ldots \ldots \ldots \ldots$

2.1 DESCRIPTION OF CORRECTIVE ACTION ACTIVITIES . . . . . . . . 11

2.1 .1 Preplanning and Site Preparation . . . . . . . . . . . . . . . . 11

2.1.2 CAS 25-02-06, Underground Storage Tank . . . . . . . . . . . . 11

2.1.3 CAS 25-04-06, Septic Systems A and B . . . . . . . . . . . 12

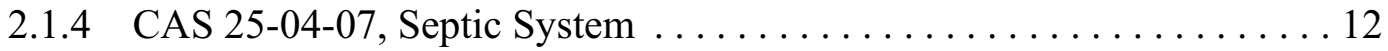

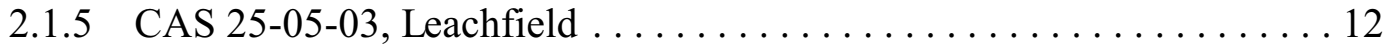

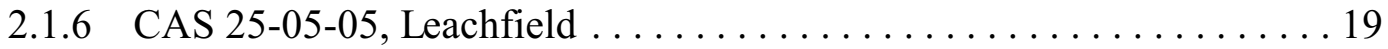

2.1.7 CAS 25-05-06, Leachfield ...................... 21

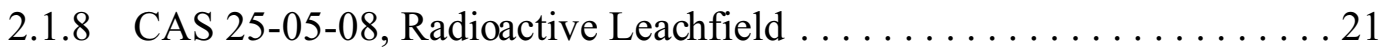

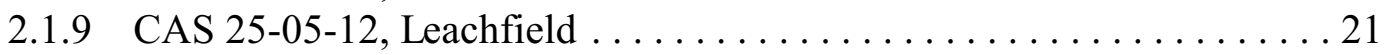

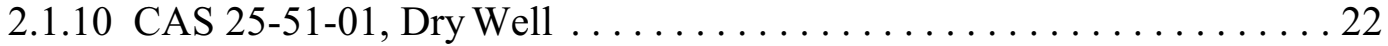

2.2 DEVIATIONS FROM CORRECTIVE ACTION PLAN AS APPROVED . . . 22

2.3 CORRECTIVE ACTION SCHEDULE AS COMPLETED . . . . . . . . 23

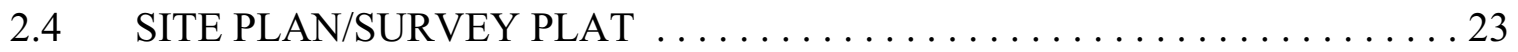

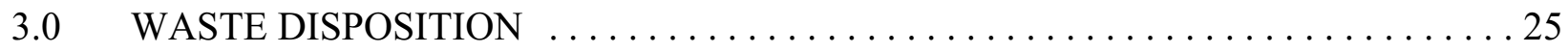

4.0 CLOSURE VERIFICATION RESULTS $\ldots \ldots \ldots \ldots \ldots \ldots \ldots \ldots \ldots \ldots \ldots \ldots$

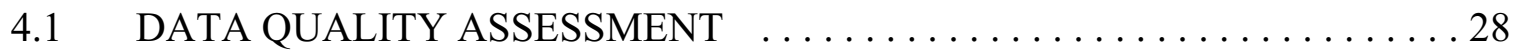

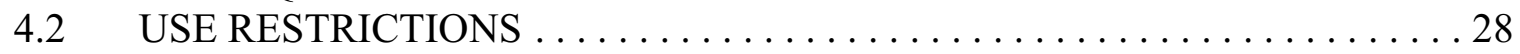

4.2.1 CAS 25-02-06, Underground Storage Tank Use Restriction . . . . . . . . 28

4.2.2 CAS 25-05-03, Leachfield Use Restriction . . . . . . . . . . . . . . . . . 29

4.2.3 CAS 25-05-06, Leachfield Use Restriction . . . . . . . . . . . . . 29

4.2.4 CAS 25-05-08, Radioactive Leachfield . . . . . . . . . . . . . . . 29

5.0 CONCLUSIONS AND RECOMMENDATIONS $\ldots \ldots \ldots \ldots \ldots \ldots \ldots \ldots \ldots \ldots$

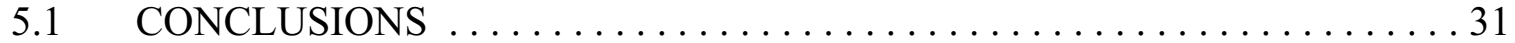

5.2 POST-CLOSURE MONITORING REQUIREMENTS $\ldots \ldots \ldots \ldots \ldots \ldots \ldots . \ldots \ldots$

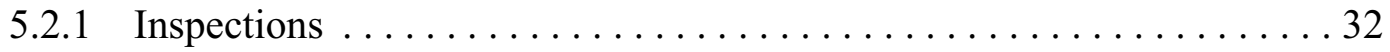

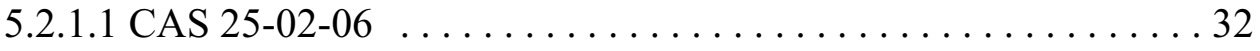

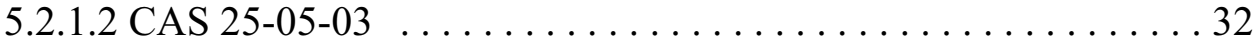

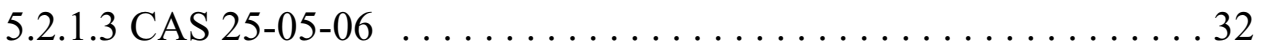

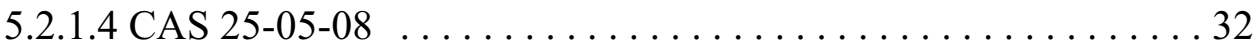

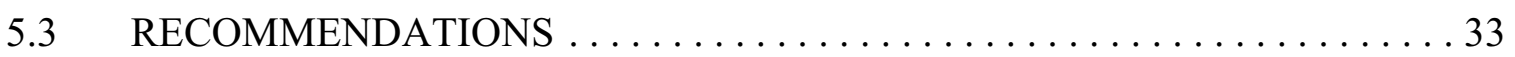




\section{TABLE OF CONTENTS (continued)}

6.0 REFERENCES 35

\section{FIGURES}

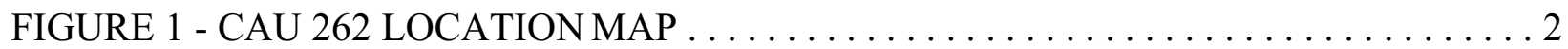

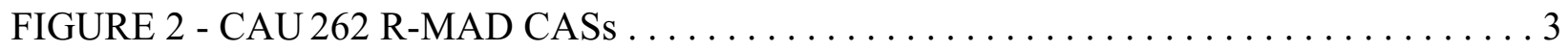

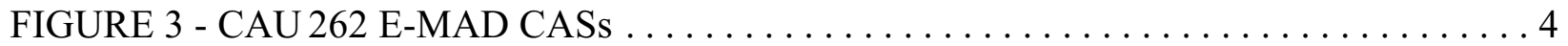

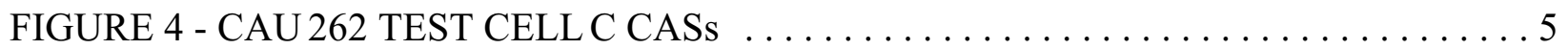

\section{TABLES}

TABLE 1 - WASTE CHARACTERIZATION SAMPLE RESULTS $\ldots \ldots \ldots \ldots \ldots \ldots$

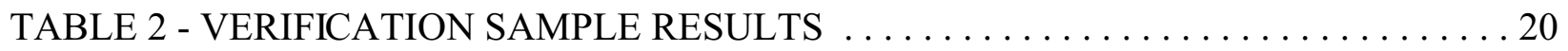

TABLE 3 - CORRECTIVE ACTION SCHEDULE AS COMPLETED ............... 24

TABLE 4 - WASTE GENERATED DURING CAU 262 CLOSURE ACTIVITIES . . . . . . . . 26

\section{APPENDICES}

APPENDIX A: DATA QUALITY OBJECTIVES FOR CAU 262

APPENDIX B: SAMPLE ANALYTICAL RESULTS

APPENDIX C: SOIL COMPACTION TEST RESULTS

APPENDIX D: RADIOLOGICAL SURVEY REPORTS

APPENDIX E: WASTE DISPOSITION DOCUMENTATION

APPENDIX F: “AS-BUILT DRAWINGS

APPENDIX G: USE RESTRICTION DOCUMENTATION

APPENDIX H: SITE CLOSURE PHOTOGRAPHS 


\section{TABLE OF CONTENTS (continued)}

APPENDIX I: APPROVED RECORDS OF TECHNICAL CHANGE

APPENDIX J: “A THROUGH K EVALUATION

APPENDIX K: NEVADA DIVISION OF ENVIRONMENTAL PROTECTION DOCUMENT REVIEW SHEET

DISTRIBUTION LIST 
CLOSURE RE PORT - CAU 262

Section: $\mathrm{T}$ able of Contents

Revision : 1

Date: July 2003

THIS PAGE INTENTIONALLY LEFT BLANK 


\section{ACRONYMS AND ABBREVIATIONS}

$\mathrm{BN}$

Bechtel Nevada

CADD Corrective Action Decision Document

CAIP Corrective Action Investigation Plan

CAP Corrective Action Plan

CAS(s) Corrective Action Site(s)

CAU Corrective Action Unit

COC Contaminant(s) of Concern

CR Closure Report

DOE/NV U.S. Department of Energy, Nevada Operations Office

DQO Data Quality Objective

E-MAD Engine Maintenance, Assembly, and Disassembly

EPA U.S. Environmental Protection Agency

$\mathrm{ft} \quad$ foot(feet)

FFACO Federal Facility Agreement and Consent Order

in inch(es)

kgs kilograms

lbs pounds

m meter(s)

$\mathrm{m}^{3} \quad$ cubic meter

MDA Minimum Detectable Activity

MDC Minimum Detectable Concentration

$\mathrm{mg} / \mathrm{kg} \quad$ milligram(s) per kilogram

$\mathrm{mg} / \mathrm{L} \quad$ milligrams(s) per liter

MTL Materials Testing Laboratory

NAC Nevada Administrative Code

NDEP Nevada Division of Environmental Protection

NNSA/NSO U.S. Department of Energy, National Nuclear Security Administration Nevada Site Office

NNSA/NV U.S. Department of Energy, National Nuclear Security Administration Nevada Operations Office

NTS Nevada Test Site

PCBs Polychlorinated biphenyls

$\mathrm{pCi} / \mathrm{g} \quad$ picoCuries per gram

$\mathrm{pCi} / \mathrm{L} \quad$ picoCuries per liter

QA/QC quality assurance/quality control 


\section{ACRONYMS AND ABBREVIATIONS (continued)}

R-MAD Reactor Maintenance, Assembly, and Disassembly

SWO Solid Waste Operations

TCLP VOC Toxicity Characteristic Leaching Procedure Volatile Organic Compounds

TPH Total Petroleum Hydrocarbons

$\mu \mathrm{g} / \mathrm{L} \quad$ micrograms per liter

$\mathrm{yd}^{3} \quad$ cubic yard(s) 
Corrective Action Unit (CAU) 262 consists of nine Corrective Action Sites (CAS) located in Area 25 of the Nevada Test Site (NTS). The NTS is located approximately 105 kilometers (65 miles) northwest of Las Vegas, Nevada. CAU 262 is listed in the Federal Facility Agreement and Consent Order (FFACO, 1996) and consists of the following CASs:

CAS 25-02-06, Underground Storage tank

CAS 25-04-06, Septic Systems A and B

CAS 25-04-07, Septic System

CAS 25-05-03, Leachfield

CAS 25-05-05, Leachfield

CAS 25-05-06, Leachfield

CAS 25-05-08, Radioactive Leachfield

CAS 25-05-12, Leachfield

CAS 25-51-01, Dry Well

CAU 262 was closed in accordance with the FFACO and the Nevada Division of Environmental Protection-approved Corrective Action Plan for Corrective Action Unit 262: Area 25 Septic Systems and Underground Discharge Point, Nevada Test Site, Nevada (U.S. Department of Energy, National Nuclear Security Administration Nevada Operations Office, 2002a). CAU 262 was closed by implementing the following corrective actions:

Four CASs were closed in place with administrative controls.

CAS 25-02-06 is a septic tank which contains Total Petroleum Hydrocarbons (TPH), polychlorinated biphenyls (PCBs), and sanitary waste. This site was closed in place by solidifying the tank contents and backfilling the tank with grout. A use restriction was implemented to control inadvertent intrusion or exposure to the tank contents.

CAS 25-05-03 is a leachfield which contains underground radiological constituents. This site was closed in place by constructing a 0.6 meter $(\mathrm{m})$ ( 2 feet [ft]) thick soil cap over the leachfield footprint. Leachfield monitoring tubes were cut off at ground level and filled with grout. The distribution box and a diversion drum were filled with grout. The subsurface vaults and valve boxes were backfilled with clean fill. The existing chain link fence was repaired and a use restriction was implemented. Permanent warning signs were installed on the fence listing use restriction and point of contact information. As a best management practice, the two washes that transect the leachfield were graded and backfilled with rip rap to limit erosion potential. The upgradient portion of the wash was modified by construction of a diversion channel of native soil and rip rap to redirect flow away from the leachfield cap.

CAS 25-05-06 is a leachfield which contains underground radiological constituents. The site was closed in place. The existing wire fence was replaced by a $2.1 \mathrm{~m}(7 \mathrm{ft})$ high chain link security fence to restrict site access. The distribution box was filled with grout. Leachfield monitoring tubes were cut off at ground level and filled with grout. Permanent warning signs were installed on the fence listing use restriction and point of contact information. 
CAS 25-05-08 is a leachfield which contains underground radiological constituents and was closed in place by constructing a $0.6-1.2 \mathrm{~m}(2-4 \mathrm{ft})$ thick soil cap over the leachfield footprint. Leachfield monitoring tubes were cut off at ground level and filled with grout. The leachfield distribution box was also filled with grout. Erosion protection was installed on the downgradient face of the soil cap. A $2.1 \mathrm{~m}$ (7 ft) chain link security fence was installed around the leachfield perimeter to restrict site access. Permanent warning signs were installed on the fence listing use restriction and point of contact information.

Four CASs were clean closed.

CAS 25-04-06 Systems A and B are septic systems that contained only sanitary waste. System A was closed by filling the empty septic tank, distribution box, and access points (manholes) with grout. System B was closed by pumping, solidifying, and disposing the tank contents. The septic tank, distribution box, and access points were filled with grout.

CAS 25-04-07 is a septic system in which the septic tank contained only sanitary waste. This site was clean closed by filling the dry, empty septic tank and distribution box with grout.

CAS 25-05 05 is a septic tank that contained TPH-impacted liquid and sludge. The site was clean closed by removing and disposing the tank contents. The tank was steam cleaned and verification samples of the rinseate were collected. The tank, distribution box, and all access points were filled with grout.

CAS 25-05-12 is a septic tank that contained TPH-impacted liquid and sludge. The site was clean closed by removing and disposing the tank contents. The tank was steam cleaned and verification samples of the rinseate were collected. The tank, distribution box, and all access points were filled with grout.

One CAS was closed by taking no further action

CAS 25-51-01 is an underground discharge point designed to receive sanitary waste. Characterization activities determined no contaminants of concern above action levels present; therefore, this site was closed by taking no further action. 


\subsection{INTRODUCTION}

This Closure Report (CR) documents the activities undertaken to close Corrective Action Unit (CAU) 262: Area 25 Septic Systems and Underground Discharge Point, in accordance with the Federal Facility Agreement and Consent Order (FFACO) of 1996. Site closure was performed in accordance with the Nevada Division of Environmental Protection (NDEP)-approved Corrective Action Plan (CAP) for CAU 262 (U.S. Department of Energy, National Nuclear Security Administration Nevada Operations Office [NNSA/NV, 2002a]). CAU 262 is located at the Nevada Test Site (NTS) approximately 105 kilometers (65 miles) northwest of Las Vegas, Nevada (see Figure 1). CAU 262 consists of the following nine Corrective Action Sites (CASs) located in Area 25 of the NTS (see Figures 2 through 4):

CAS 25-02-06, Underground Storage tank

CAS 25-04-06, Septic Systems A and B

CAS 25-04-07, Septic System

CAS 25-05-03, Leachfield

CAS 25-05-05, Leachfield

CAS 25-05-06, Leachfield

CAS 25-05-08, Radioactive Leachfield

CAS 25-05-12, Leachfield

CAS 25-51-01, Dry Well

Copies of the analytical results for the site verification samples are included in Appendix B. Copies of the CAU Use Restriction Information forms are included in Appendix G.

\subsection{PURPOSE}

The purpose of this CR is to document that the closure of CAU 262 complied with all of the closure requirements detailed in the NDEP-approved CAP (NNSA/NV, 2002a) and to provide data confirming the clean closure. CAU 262 was investigated and closed using the FFACO complex process. Details of the investigation activities are documented in the CAU 262 Corrective Action Investigation Plan (CAIP) (U.S. Department of Energy, Nevada Operations Office)[DOE/NV, 2000]). Results of the investigation activities are presented in the Corrective Action Decision Document (CADD) for CAU 262 (NNSA/NV, 2001).

CAS 25-02-06 is a septic system that received sanitary effluent from Building 3900 at the Engine Maintenance, Assembly, and Disassembly (E-MAD) facility. The leachfield contains no contaminants of concern (COC) above action levels. The septic tank contains sanitary waste, Total Petroleum Hydrocarbons (TPH), and polychlorinated biphenyls (PCBs) above action levels. This site was closed in place by solidifying the septic tank contents and filling the remaining void space with grout. Access points were also filled with grout. Use restrictions were implemented to restrict access into the tank. 


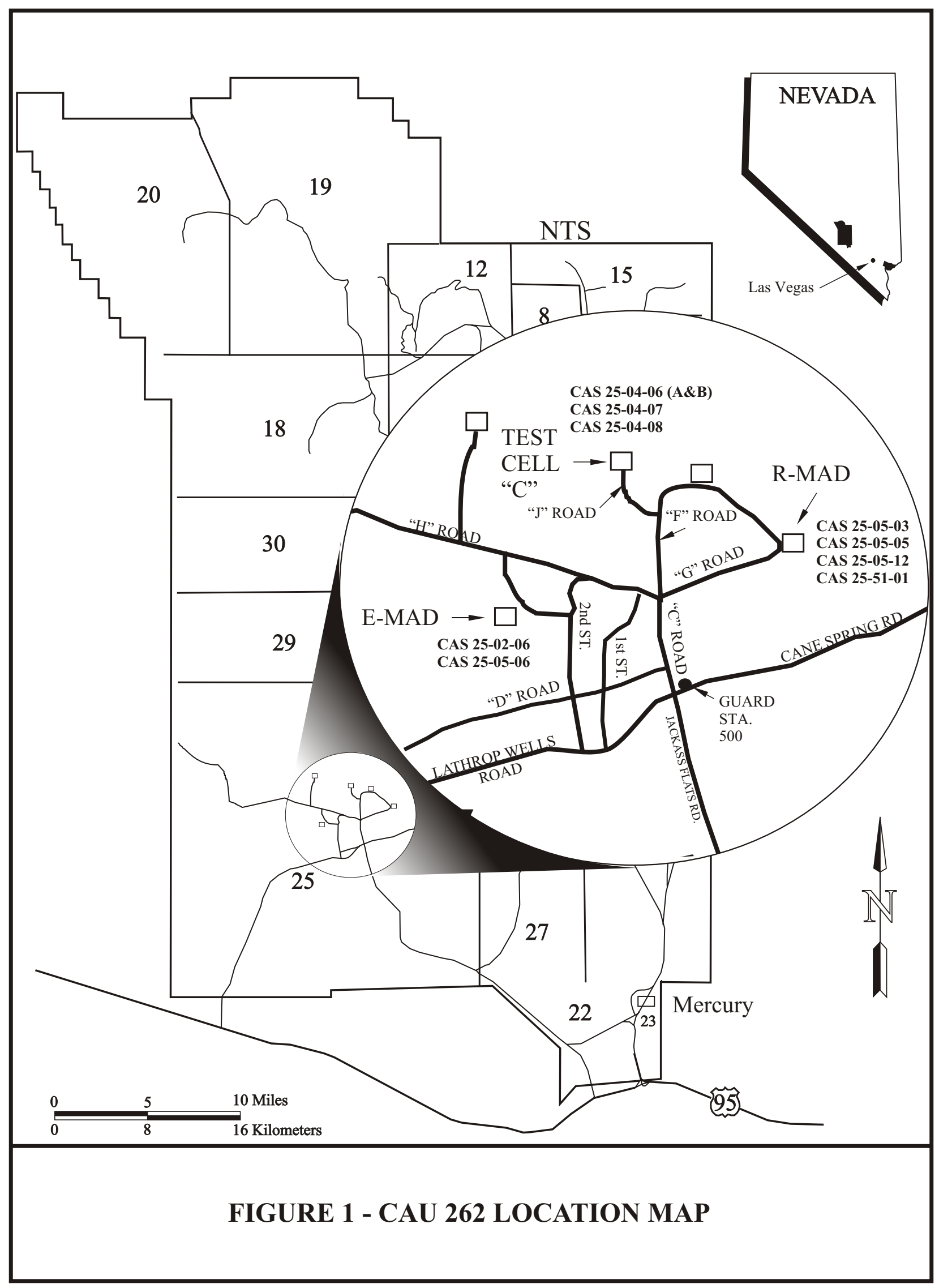



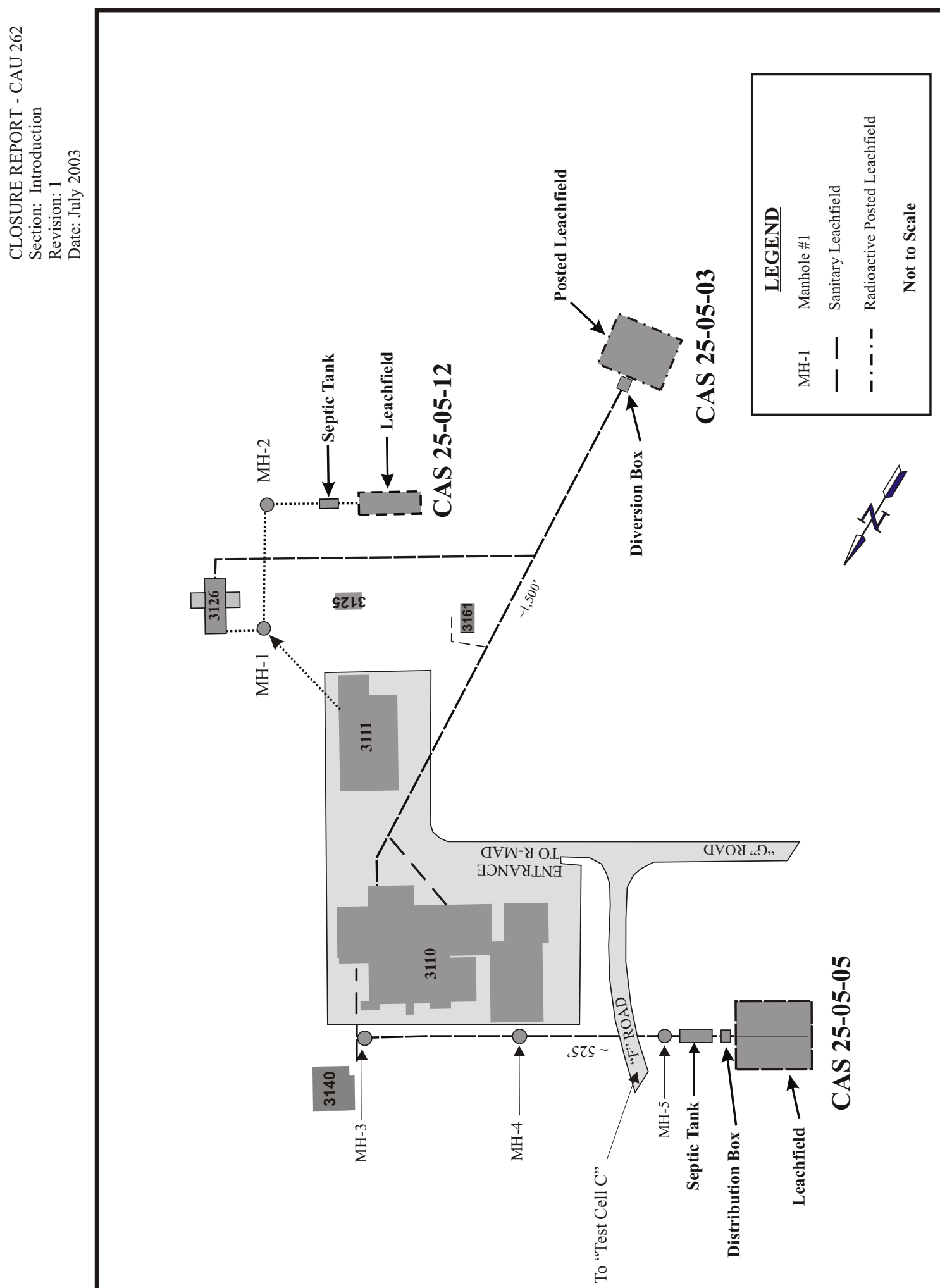


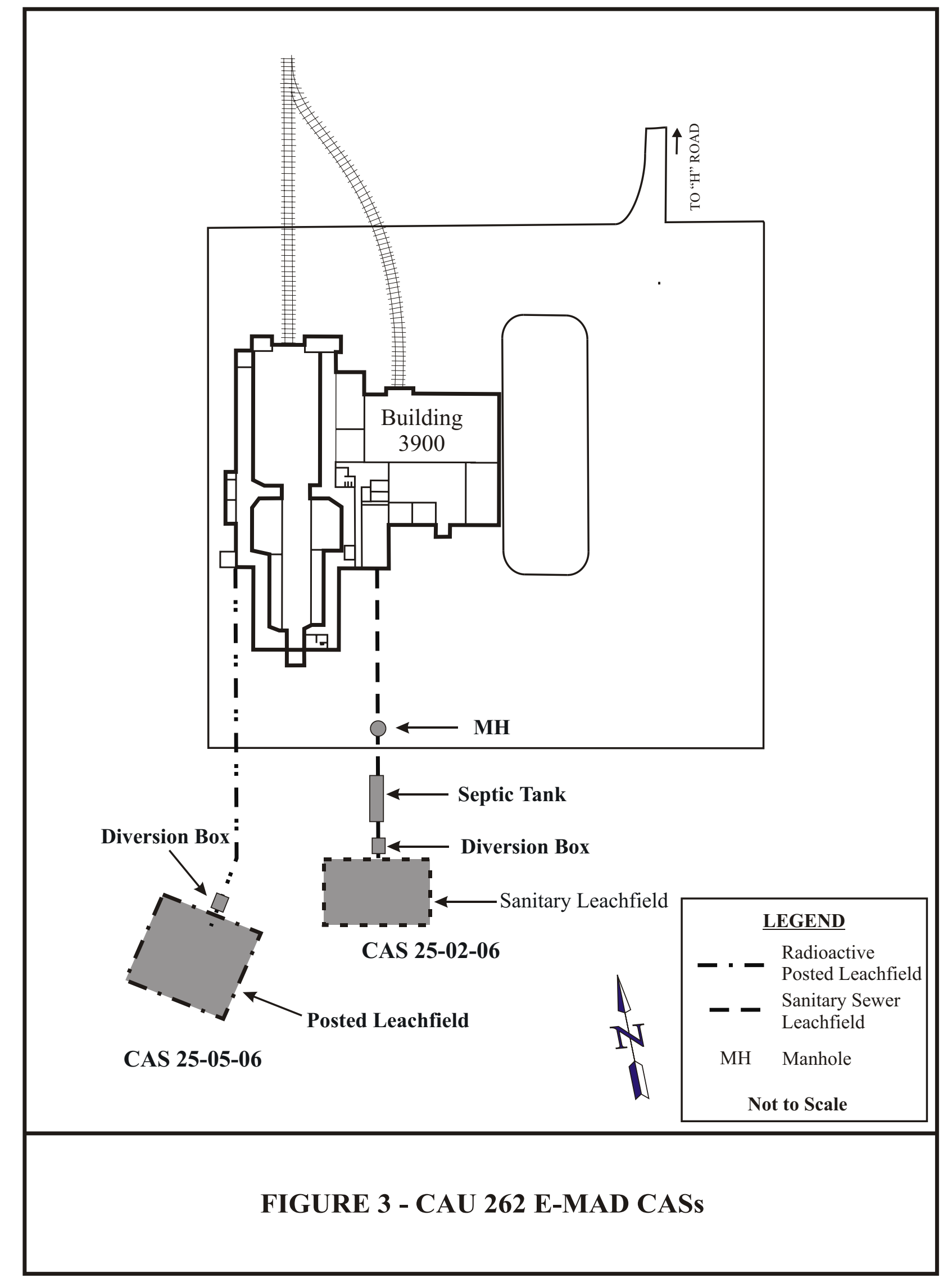




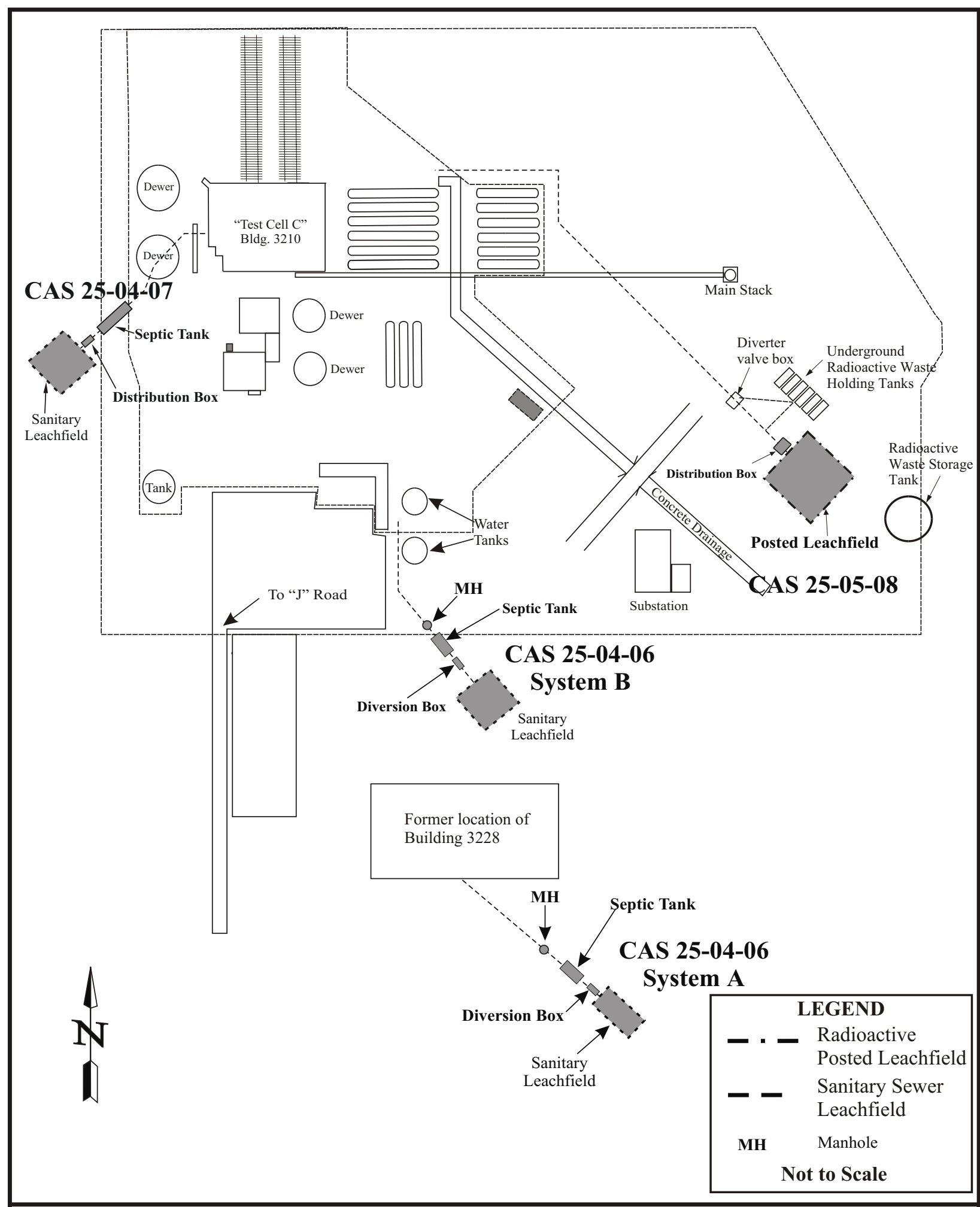

FIGURE 4 - CAU 262 TEST CELL C CASs 
CAS 25-04-06 consists of two septic systems (A and B) which received sanitary effluent from Buildings 3228 and 3220, respectively at the Test Cell C facility. Results of characterization activities presented in the CADD for CAU 262 indicated the septic tanks and leachfields contained no COC, only sanitary waste (NNSA/NV, 2001). System A septic tank contained no liquid or sludge and was clean closed by filling the septic tank, distribution box, and upstream manhole with grout. System B was clean closed by removing and disposing the septic tank contents and filling the tank, distribution box, and upstream manhole with grout.

CAS 25-04-07 is a septic system which received sanitary effluent from Building 3210 at the Test Cell C facility. Characterization results indicated the septic tank and leachfield contained only sanitary waste (NNSA/NV, 2001). However, during closure activities the septic tank and distribution box were found to contain no liquid or sludge and was clean closed by filling with grout.

CAS 25-05-03 is a leachfield that received radioactive effluent from the Reactor-Maintenance, Assembly, and Disassembly (R-MAD) facility. The leachfield contains underground radiologic al COC (NNS A/NV, 2001). The leachfield was closed in place by installing a 0.6 meter $(\mathrm{m})$ ( 2 feet [ft]) thick cap over the leachfield. The cap was constructed of clean native soil in three $0.2 \mathrm{~m}$ (8 inch [in.]) thick lifts. Each lift was compacted to 90 percent of maximum density. Prior to installing the cap, all monitoring tubes were cut off at ground level and filled with grout. The distribution box and a diversion drum were filled with grout. Two valve boxes located within the leachfield were backfilled with clean fill. As a best management practice to control potential erosion, existing surface washes were graded and backfilled with rip-rap. A rip-rap lined channel was constructed along the upgradient side of the leachfield to divert overland flow away from the leachfield cap. The existing chain link security fence was repaired and permanent warning signs were affixed to the fence. A Use Restriction was implemented to restrict intrusive activity into or beneath the site.

CAS 25-05-05 is a septic tank that received sanitary effluent from Buildings 3110 and 3140 at the R-MAD facility. The tank contained TPH above the Nevada state action level of 100 milligrams per kilogram (mg/kg) [Nevada Administrative Code (NAC), 2002a], and sanitary waste (NNSA/NV, 2001). The tank was clean closed by removing, solidifying, and disposing the tank contents. The tank was pressure washed/steam cleaned and the rinseate was sampled to verify that no COC remained in the tank. The tank, distribution box and access points were filled with grout.

CAS 25-05-06 is a leachfield that received radioactive effluent from the E-MAD facility and contains underground radiological COC (NNSA/NV, 2001). The leachfield was closed in place

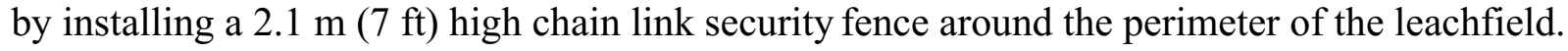
Monitoring tubes within the leachfield were cut off at ground level and filled with grout. The existing fence was removed and disposed. Permanent warning signs were affixed to the new fence and a Use Restriction was implemented to restrict intrusive activity into the leachfield. 
CAS 25-05-08 is a leachfield that received radioactive effluent from Building 3210 at the Test Cell C facility. The site was closed in place by installing a 0.6-1.2 m (2-4 ft) thick cap over the leachfield. The cap was constructed of clean native soil in six $0.2 \mathrm{~m}(8 \mathrm{in}$.) thick lifts. Each lift was compacted to 90 percent of maximum density. Prior to installing the cap, all monitoring tubes were cut off at the surface and filled with grout. The buried distribution box was exposed and filled with grout. The existing fence was removed and disposed and a new $2.1 \mathrm{~m}(7 \mathrm{ft})$ high chain link security fence was installed around the perimeter of the leachfield. As a best management practice to control potential erosion, a cellular confinement system filled with aggregate was installed on the downgradient south face of the cap. Permanent warning signs were affixed to the new fence and a Use Restriction was implemented to restrict intrusive activity into or beneath the site.

CAS 25-05-12 is a septic tank that received sanitary effluent from Buildings 3111 and 3126 at the R-MAD facility. The tank contained TPH above the state action level of $100 \mathrm{mg} / \mathrm{kg}$ (NAC, 2002a), and sanitary waste (NNSA/NV, 2001). The tank was clean closed by removing, solidifying, and disposing the tank contents. The tank was pressure washed/steam cleaned and the rinseate was sampled to verify that no COC remained in the tank. The tank, distribution box, and access points were filled with grout.

CAS 25-51-01 is an underground discharge point that received sanitary waste from Building 3125 at the R-MAD facility. Characterization indicated this CAS contained no COC (NNSA/NV, 2001) and was therefore closed by taking no further action.

\subsection{SCOPE}

The closure strategy for CAU 262 was specified in the NDEP-approved CAP for CAU 262 (NNSA/NV, 2002a). The nine CASs in CAU 262 were closed as follows:

CAS 25-02-06, Underground Storage tank - Closed in place with administrative controls CAS 25-04-06, Septic Systems A and B - Clean closed

CAS 25-04-07, Septic System - Clean closed

CAS 25-05-03, Leachfield - Closed in place with administrative controls

CAS 25-05-05, Leachfield - Clean closed

CAS 25-05-06, Leachfield - Closed in place with administrative controls

CAS 25-05-08, Radioactive Leachfield - Closed in place with administrative controls

CAS 25-05-12, Leachfield - Clean closed

CAS 25-51-01, Dry Well - No further action

CASs 25-05-05 and 25-05-12 were the only CASs requiring verification data. The tank contents were removed, the tanks were rinsed, and the rinseate sampled to verify that all waste above the TPH action level was removed. The tanks were then filled with grout. CASs 25-04-06 and 2504-07 did not contain COC above action levels and were closed by removing the sanitary waste as applicable and filling the tanks with grout. CAS 25-51-01 was closed by taking no further action. All other CASs were closed in place. 


\subsection{CLOSURE REPORT CONTENTS}

This CR is divided into the following sections:

Section 1.0 - Introduction

Section 2.0 - Closure Activities

Section 3.0 - Waste Disposition

Section 4.0 - Closure Verification Results

Section 5.0 - Conclusions and Recommendations

Section 6.0 - References

Appendix A - Data Quality Objectives

Appendix B - Sample Analytical Results

Appendix C - Soil Compaction Test Results

Appendix D - Radiological Survey Reports

Appendix E - Waste Disposition Documentation

Appendix F - "As-Built Drawings

Appendix G - Use Restriction Documentation

Appendix H - Site Closure Photographs

Appendix I - Approved Records of Technical Change

Appendix J - “A Through K Evaluation

Distribution List

The following standard FFACO CR appendices are not included in this CR because they do not apply to closure of CAU 262.

Closure Certification - Not applicable.

Modifications to the Post-Closure Plan - Not applicable. 
This report was developed using information and guidance from the following documents:

Corrective Action Plan for Corrective Action Unit 262: Area 25 Septic Systems and Underground Discharge Point, Nevada Test Site, Nevada (NNSA/NV, 2002a).

Field Management Plan for Corrective Action Unit 262: Area 25 Septic Systems and Underground Discharge Point, Nevada Test Site, Nevada. (Bechtel Nevada [BN], 2001a).

Site-Specific Health and Safety Plan for Corrective Action Unit 262: Area 25 Septic Systems and Underground Discharge Point, Nevada Test Site, Nevada (BN, 2001b).

Nevada Environmental Restoration Project, Industrial Sites Quality Assurance Project Plan, Nevada Test Site, Nevada, Revision 3 (NNSA/NV, 2002b).

\subsubsection{Data Quality Objectives}

The data quality objectives (DQOs) used for closure of CAU 262 were presented in Appendix A of the CAIP (DOE/NV, 2000), and are included as Appendix A of this report.

The general conceptual model as presented in the CAIP (DOE/NV, 2000) was applied to all the CASs in CAU 262 and assumed that any subsurface contamination was the result of both designed and accidental releases. The potential contamination would be restricted to those areas immediately beneath and adjacent to the system components. The extent of the potential contamination was dependent upon such variables as release volume, system design, geologic conditions, and nature of contaminants.

CAU 262 characterization activities determined that actual site conditions were in agreement with the conceptual model. This information is presented in the CADD (NNSA/NV, 2001). Closure activities also indicated the conceptual model was accurate.

Details of the DQO assessment are included in Section 4.1 of this report. 
CLOSURE RE PORT - CAU 262

Section: Introduction

Revision : 1

Date: July 2003

THIS PAGE INTENTIONALLY LEFT BLANK 


\subsection{CLOSURE ACTIVITIES}

This section details the specific corrective action activities completed during the closure of CAU 262: Area 25 Septic Systems and Underground Discharge Point. Copies of the analytical data reports for all verification samples are included in Appendix B.

\subsection{DESCRIPTION OF CORRECTIVE ACTION ACTIVITIES}

\subsubsection{Preplanning and Site Preparation}

Closure of CAU 262 was completed using the NDEP-approved CAP (NNSA/NV, 2002a). Prior to beginning site closure activities, the following pre-field activities were completed:

Preparation of National Environmental Policy Act documentation (checklist).

Preparation of the Field Management Plan for Corrective Action Unit 262: Area 25 Septic Systems and Underground Discharge Point, Nevada Test Site, Nevada, (BN, 2001a).

Preparation of the Site-Specific Health and Safety Plan for Closure Activities at Corrective Action Unit 262: Nevada Test Site, Nevada, (BN, 2001b).

Preparation of a U.S. Department of Energy, National Nuclear Security Administration Nevada Site Office (NNSA/NSO) Real Estate/Operations Permit.

Preparation of required $\mathrm{BN}$ work permits.

Preparation of $\mathrm{BN}$ work control packages

Preparation of engineering design specifications

The following is the scope of the closure actions implemented for CAU 262. Closure activities occurred from December 2002-April 2003.

\subsubsection{CAS 25-02-06, Underground Storage Tank}

This CAS was closed by closure in place with administrative controls. The tank contents were solidified by mixing with dry Portland Type II cement. Approximately 14 cubic meters $\left(\mathrm{m}^{3}\right)$ (18.5 cubic yards $\left[\mathrm{yd}^{3}\right]$ ) of cement were used to solidify the tank contents. The remaining void spaces were filled with concrete. Approximately $42 \mathrm{~m}^{3}\left(55 \mathrm{yd}^{3}\right)$ of concrete were used to fill the tank, distribution box, and one upstream access point (manhole). A Use Restriction was implemented and signs were posted on " $\mathrm{T}$ posts to restrict access to the tank. 


\subsubsection{CAS 25-04-06, Septic Systems A and B}

This CAS was closed by clean closure. The Septic System A tank was exposed using a backhoe. The tank was metal and extremely rusted. The top of the tank was removed with the backhoe. Visual observation showed the tank to be dry. Excavating to the tank bottom also showed the tank to be dry with no evidence of sludge. The distribution box and manhole were also found to be dry. The septic tank, distribution box, and manhole were completely filled with approximately $6 \mathrm{~m}^{3}\left(8 \mathrm{yd}^{3}\right)$ of grout. The excavation was then backfilled with clean soil.

Septic System B was closed by removing the sanitary liquid from the tank. The liquid was pumped from the tank using a vacuum truck. The tank was rinsed and the rinseate was also removed using a vacuum truck. The liquid was then pumped into a lined basin and solidified with clean soil. The septic tank, distribution box, and manhole were then filled with grout. Approximately $7 \mathrm{~m}^{3}\left(9 \mathrm{yd}^{3}\right)$ of grout was required to fill these structures. The solidified tank contents were disposed of in the NTS Area 23 Sanitary Landfill. Approximately $37 \mathrm{~m}^{3}\left(48 \mathrm{yd}^{3}\right)$ of waste was disposed. Per the request of BN Solid Waste Operations (SWO), the waste was sampled prior to disposal. The samples were analyzed for gross alpha/beta and gamma spectroscopy. The results indicated that the waste met landfill requirements for radiological constituents. The sample results are presented in Table 1 and the analytical data is included in Appendix B.

\subsubsection{CAS 25-04-07, Septic System}

This CAS was closed by clean closure. Access to the septic tank was achieved by removing part of a concrete slab that covered most of the tank. The tank was visually inspected and found to be empty and dry. Characterization results indicated that the tank contained only sanitary liquid. Since no liquid was present in the tank, closure was achieved by filling the septic tank and distribution box with grout. Approximately $5 \mathrm{~m}^{3}\left(7 \mathrm{yd}^{3}\right)$ of grout was used to completely fill the tank and distribution box. Clean soil was used to backfill the area to surface grade.

\subsubsection{CAS 25-05-03, Leachfield}

This CAS was closed by closure in place with administrative controls. A minimum $0.6 \mathrm{~m}$ (2 ft) thick soil cap was constructed over the leachfield footprint. The cap was constructed of three 0.2 $\mathrm{m}$ (8 in) lifts of clean, native soil. Each lift was compacted to at least 90 percent of the maximum density of the fill material. A minimum of four compaction tests were done per complete lift. Supplemental lifts (additional lifts required to compensate for variations in the leachfield topography) required a minimum of one compaction test. The compaction tests were conducted in the field by BN Material Testing Laboratory (MTL) personnel. The test results are included in Appendix C. The existing chain link security fence was retained and repaired where nece ssary.

Prior to installing the soil cover, all the leachfield monitoring tubes were cut off at ground level and filled with grout. The cut tubes were found not to be radiologically impacted and were disposed in the NTS Area 9 Construction Landfill. The radiological survey reports are included in Appendix D and Waste Disposition Records are presented in Appendix E. 
TABLE 1 - WASTE CHARACTERIZATION SAMPLE RESULTS

\begin{tabular}{|c|c|c|c|}
\hline PARAMETER & SAMPLE ID & $\begin{array}{l}\text { RESULT } \\
(\mathrm{mg} / \mathrm{kg})^{\mathrm{a}}\end{array}$ & $\begin{array}{l}\text { REPORTING LIMIT } \\
(\mathbf{m g} / \mathrm{kg})^{\mathrm{a}}\end{array}$ \\
\hline \multicolumn{4}{|c|}{ CAS 25-05-05 } \\
\hline $\mathrm{TPH}^{\mathrm{b}}$ Diesel & 250505-Waste-1 & $<60$ & 60 \\
\hline TPH Gasoline & 250505-Waste-1 & 100 & 60 \\
\hline TPH Oil & 250505-Waste-1 & 390 & 150 \\
\hline TPH Total & 250505-Waste-1 & 490 & 60 \\
\hline TPH Diesel & 250512-Waste-1 & 1100 & 60 \\
\hline TPH Gasoline & 250512-Waste-1 & 83 & 60 \\
\hline TPH Oil & 250512-Waste-1 & $<150$ & 150 \\
\hline TPH Total & 250512-Waste-1 & 1200 & 60 \\
\hline $\begin{array}{l}\text { PARAMETER } \\
\text { (TCLP VOC) }^{\mathrm{c}}\end{array}$ & SAMPLE ID & $\operatorname{RESULT}(\mathrm{mg} / \mathrm{L})^{\mathrm{d}}$ & $\begin{array}{l}\text { REPORTING LIMIT } \\
(\mathrm{mg} / \mathrm{L})^{\mathrm{d}}\end{array}$ \\
\hline Benzene & 250505-Waste-1 & $<0.10$ & 0.10 \\
\hline Carbon Tetrachloride & 250505-Waste-1 & $<0.10$ & 0.10 \\
\hline Chlorobenzene & 250505-Waste-1 & $<0.10$ & 0.10 \\
\hline Chloroform & 250505-Waste-1 & $<0.10$ & 0.10 \\
\hline 1,4-Dichlorobenzene & 250505-Waste-1 & $<0.10$ & 0.10 \\
\hline 1,1-Dicholroethene & 250505-Waste-1 & $<0.10$ & 0.10 \\
\hline 1,2-Dichloroethane & 250505-Waste-1 & $<0.10$ & 0.10 \\
\hline Methyl ethyl ketone & 250505-Waste-1 & $<0.50$ & 0.50 \\
\hline Tetrachloroethene & 250505-Waste-1 & $<0.10$ & 0.10 \\
\hline Trichloroethene & 250505-Waste-1 & $<0.10$ & 0.10 \\
\hline Vinyl chloride & 250505-Waste-1 & $<0.10$ & 0.10 \\
\hline 1,1,1-Trichloroethane & 250505-Waste-1 & $<0.10$ & 0.10 \\
\hline Toluene & 250505-Waste-1 & $<0.10$ & 0.10 \\
\hline Ethylbenzene & 250505-Waste-1 & $<0.10$ & 0.10 \\
\hline Total Xylenes & 250505-Waste-1 & $<0.20$ & 0.20 \\
\hline
\end{tabular}


TABLE 1 - WASTE CHARACTERIZATION SAMPLE RESULTS (Continued)

\begin{tabular}{|c|c|c|c|}
\hline PARAMETER & SAMPLE ID & $\operatorname{RESULT}(p C i / L)^{e}$ & $\operatorname{MDC}^{f}(p C i / L)^{e}$ \\
\hline Gross Alpha & 250505-Waste-1 & $1.12 \mathrm{E}+03$ & $2.98 \mathrm{E}+02$ \\
\hline Gross Beta & 250505-Waste-1 & $2.87 \mathrm{E}+03$ & $3.65 \mathrm{E}+02$ \\
\hline PARAMETER & SAMPLE ID & $\operatorname{RESULT}(\mathrm{pCi} / \mathrm{g})^{\mathrm{g}}$ & $\operatorname{MDC}^{\mathrm{f}}(\mathrm{pCi} / \mathrm{g})^{\mathrm{g}}$ \\
\hline Gross Alpha & 250505-Waste-2 & $3.60 \mathrm{E}+00$ & $6.47 \mathrm{E}-01$ \\
\hline Gross Beta & 250505-Waste-2 & $3.96 \mathrm{E}+00$ & $9.46 \mathrm{E}-01$ \\
\hline \multicolumn{4}{|c|}{ CAS 25-04-06 } \\
\hline Gross Alpha & 250406B-Waste-1 & $4.59 \mathrm{E}+00$ & $3.53 \mathrm{E}-01$ \\
\hline Gross Beta & 250406B-Waste- 1 & $4.55 \mathrm{E}+00$ & $6.73 \mathrm{E}-01$ \\
\hline \multicolumn{4}{|c|}{ CAS 25-05-12 } \\
\hline Gross Alpha & 250512-Waste-1 & $1.22 \mathrm{E}+00$ & $3.18 \mathrm{E}-01$ \\
\hline Gross Beta & 250512-Waste-1 & $1.72 \mathrm{E}+00$ & 4.70E-01 \\
\hline Gross Alpha & 250512-Waste-2 & $4.79 \mathrm{E}+00$ & $1.12 \mathrm{E}+00$ \\
\hline Gross Beta & 250512-Waste-2 & $3.73 \mathrm{E}+00$ & $1.77 \mathrm{E}+00$ \\
\hline $\begin{array}{l}\text { PARAMETER } \\
\text { (GAMMA } \\
\text { SPECTROSCOPY) }\end{array}$ & SAMPLE ID & 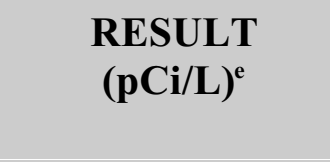 & $\operatorname{MDC}^{f}(p C i / L)^{e}$ \\
\hline \multicolumn{4}{|c|}{ CAS 25-05-05 } \\
\hline Actinium-228 & 250505-Waste-1 & $3.05 \mathrm{E}+01$ & $3.35 \mathrm{E}+01$ \\
\hline Americium- 241 & 250505-Waste-1 & $-2.92 \mathrm{E}+00$ & $9.84 \mathrm{E}+00$ \\
\hline Cerium-144 & 250505-Waste-1 & $-1.88 \mathrm{E}+01$ & $3.38 \mathrm{E}+01$ \\
\hline Cobalt-60 & 250505-Waste-1 & $-1.40 \mathrm{E}+00$ & $1.02 \mathrm{E}+01$ \\
\hline Cesium-134 & 250505-Waste-1 & $6.36 \mathrm{E}-01$ & $8.77 \mathrm{E}+00$ \\
\hline Cesium-137 & 250505-Waste-1 & $1.12 \mathrm{E}+02$ & $8.52 \mathrm{E}+00$ \\
\hline Europium-152 & 250505-Waste-1 & $-8.09 \mathrm{E}+00$ & $5.26 \mathrm{E}+01$ \\
\hline Europium-154 & 250505-Waste-1 & $5.50 \mathrm{E}+00$ & $4.94 \mathrm{E}+01$ \\
\hline Europium-155 & 250505-Waste-1 & $-2.84 \mathrm{E}+00$ & $1.60 \mathrm{E}+01$ \\
\hline Potassium-40 & 250505-Waste-1 & $2.96 \mathrm{E}+02$ & $1.61 \mathrm{E}+02$ \\
\hline
\end{tabular}




\section{TABLE 1 - WASTE CHARACTERIZATION SAMPLE RESULTS (Continued)}

\begin{tabular}{|c|c|c|c|}
\hline $\begin{array}{c}\text { PARAMETER } \\
\text { (GAMMA } \\
\text { SPECTROSCOPY) }\end{array}$ & SAMPLE ID & $\begin{array}{l}\text { RESULT } \\
(\mathbf{p C i} / \mathbf{L})^{\mathrm{e}}\end{array}$ & $\operatorname{MDC}^{f}(p C i / L)^{e}$ \\
\hline Lead-212 & 250505-Waste-1 & $3.12 \mathrm{E}+01$ & $1.47 \mathrm{E}+01$ \\
\hline Promethium-144 & 250505-Waste-1 & $3.97 \mathrm{E}+00$ & $8.45 \mathrm{E}+00$ \\
\hline Promethium-146 & 250505-Waste-1 & $-2.23 \mathrm{E}+00$ & $1.08 \mathrm{E}+01$ \\
\hline Ruthenium-106 & 250505-Waste- 1 & $-1.97 \mathrm{E}+01$ & $8.14 \mathrm{E}+01$ \\
\hline Antimony-125 & 250505-Waste-1 & $2.64 \mathrm{E}+00$ & $2.21 \mathrm{E}+01$ \\
\hline Thorium-234 & 250505-Waste-1 & $8.65 \mathrm{E}+01$ & $1.09 \mathrm{E}+02$ \\
\hline Uranium-235 & 250505-Waste- 1 & $3.16 \mathrm{E}+00$ & $4.23 \mathrm{E}+01$ \\
\hline Yttrium-88 & 250505-Waste-1 & $4.37 \mathrm{E}+00$ & $8.59 \mathrm{E}+00$ \\
\hline \multicolumn{2}{|l|}{$\begin{array}{c}\text { PARAMETER } \\
\text { (GAMMA } \\
\text { SPECTROSCOPY) }\end{array}$} & $\operatorname{RESULT}(p \mathrm{Ci} / \mathrm{g})^{\mathrm{g}}$ & $\operatorname{MDC}^{f}(p C i / g)^{g}$ \\
\hline Actinium-228 & 250505-Waste-2 & $1.05 \mathrm{E}+00$ & $7.58 \mathrm{E}-01$ \\
\hline Americium- 241 & 250505-Waste-2 & $3.28 \mathrm{E}-01$ & $1.13 \mathrm{E}+00$ \\
\hline Cerium-144 & 250505-Waste-2 & $-2.02 \mathrm{E}-02$ & $6.64 \mathrm{E}-01$ \\
\hline Cobalt-60 & 250505-Waste-2 & $-7.97 \mathrm{E}-02$ & $2.57 \mathrm{E}-01$ \\
\hline Cesium-134 & 250505-Waste-2 & $6.85 \mathrm{E}-03$ & $1.68 \mathrm{E}-01$ \\
\hline Cesium-137 & 250505-Waste-2 & $3.36 \mathrm{E}-02$ & $1.64 \mathrm{E}-01$ \\
\hline Europium-152 & 250505-Waste-2 & $5.22 \mathrm{E}-01$ & $5.68 \mathrm{E}-01$ \\
\hline Europium-154 & 250505-Waste-2 & $-1.13 \mathrm{E}-01$ & $9.39 \mathrm{E}-01$ \\
\hline Europium-155 & 250505-Waste-2 & $2.32 \mathrm{E}-01$ & $3.97 \mathrm{E}-01$ \\
\hline Potassium-40 & 250505-Waste- 2 & $2.19 \mathrm{E}+01$ & $1.97 \mathrm{E}+00$ \\
\hline Lead-212 & 250505-Waste-2 & $1.19 \mathrm{E}+00$ & $3.12 \mathrm{E}-01$ \\
\hline Promethium-144 & 250505-Waste-2 & $-7.66 \mathrm{E}-03$ & $1.80 \mathrm{E}-01$ \\
\hline Promethium-146 & 250505-Waste-2 & $7.53 \mathrm{E}-02$ & $1.91 \mathrm{E}-01$ \\
\hline Ruthenium-106 & 250505-Waste-2 & $-2.81 \mathrm{E}-01$ & $1.65 \mathrm{E}+00$ \\
\hline
\end{tabular}




\section{TABLE 1 - WASTE CHARACTERIZATION SAMPLE RESULTS (Continued)}

\begin{tabular}{|c|c|c|c|}
\hline $\begin{array}{l}\text { PARAMETER } \\
\text { (GAMMA } \\
\text { SPECTROSCOPY) }\end{array}$ & SAMPLE ID & $\operatorname{RESULT}(p \mathrm{Ci} / \mathrm{g})^{\mathrm{g}}$ & $\operatorname{MDC}^{f}(p C i / g)^{g}$ \\
\hline Antimony-125 & 250505-Waste-2 & $3.06 \mathrm{E}-02$ & $4.26 \mathrm{E}-01$ \\
\hline Thorium-234 & 250505-Waste-2 & $2.31 \mathrm{E}+00$ & $2.79 \mathrm{E}+00$ \\
\hline Uranium-235 & 250505-Waste-2 & $2.36 \mathrm{E}-01$ & $6.59 \mathrm{E}-01$ \\
\hline Yttrium-88 & 250505-Waste-2 & $3.90 \mathrm{E}-02$ & $1.71 \mathrm{E}-01$ \\
\hline \multicolumn{4}{|c|}{ CAS 25-04-06 } \\
\hline Actinium-228 & 250406B-Waste-1 & $1.96 \mathrm{E}+00$ & $1.11 \mathrm{E}+00$ \\
\hline Americium-241 & 250406B-Waste-1 & $5.01 \mathrm{E}-01$ & $1.17 \mathrm{E}+00$ \\
\hline Cerium-144 & 250406B-Waste-1 & $1.12 \mathrm{E}-01$ & $9.43 \mathrm{E}-01$ \\
\hline Cobalt- 60 & 250406B-Waste-1 & $-8.34 \mathrm{E}-02$ & $3.08 \mathrm{E}-01$ \\
\hline Cesium-134 & 250406B-Waste-1 & $1.10 \mathrm{E}-02$ & $2.09 \mathrm{E}-01$ \\
\hline Cesium-137 & 250406B-Waste-1 & $-5.63 \mathrm{E}-02$ & $2.65 \mathrm{E}-01$ \\
\hline Europium-152 & 250406B-Waste-1 & $-3.50 \mathrm{E}-01$ & $1.36 \mathrm{E}+00$ \\
\hline Europium-154 & 250406B-Waste-1 & $6.87 \mathrm{E}-01$ & $1.21 \mathrm{E}+00$ \\
\hline Europium-155 & 250406B-Waste-1 & $3.90 \mathrm{E}-01$ & $5.10 \mathrm{E}-01$ \\
\hline Potassium-40 & 250406B-Waste-1 & $3.23 \mathrm{E}+01$ & $3.36 \mathrm{E}+00$ \\
\hline Lead-212 & 250406B-Waste-1 & $1.81 \mathrm{E}+00$ & $3.26 \mathrm{E}-01$ \\
\hline Promethium-144 & 250406B-Waste-1 & $1.13 \mathrm{E}-01$ & $2.25 \mathrm{E}-01$ \\
\hline Promethium-146 & 250406B-Waste-1 & $1.34 \mathrm{E}-02$ & $2.84 \mathrm{E}-01$ \\
\hline Ruthenium-106 & 250406B-Waste-1 & $-7.52 \mathrm{E}-01$ & $2.53 \mathrm{E}+00$ \\
\hline Antimony-125 & 250406B-Waste-1 & $0.00 \mathrm{E}+00$ & $4.96 \mathrm{E}-01$ \\
\hline Thorium-234 & 250406B-Waste-1 & $-1.56 \mathrm{E}-01$ & $3.63 \mathrm{E}+00$ \\
\hline Uranium-235 & 250406B-Waste-1 & $1.04 \mathrm{E}-04$ & $1.02 \mathrm{E}+00$ \\
\hline Yttrium-88 & 250406B-Waste-1 & $-1.83 \mathrm{E}-02$ & 2.92E-01 \\
\hline
\end{tabular}


TABLE 1 - WASTE CHARACTERIZATION SAMPLE RESULTS (Continued)

\begin{tabular}{|c|c|c|c|}
\hline $\begin{array}{c}\text { PARAMETER } \\
\text { (GAMMA } \\
\text { SPECTROSCOPY) }\end{array}$ & SAMPLE ID & $\operatorname{RESULT}(\mathrm{pCi} / \mathrm{g})^{\mathrm{g}}$ & $\operatorname{MDC}^{\mathrm{f}}(\mathbf{p C i} / \mathrm{g})^{\mathrm{g}}$ \\
\hline \multicolumn{4}{|c|}{ CAS 25-05-12 } \\
\hline Actinium-228 & 250512-Waste-1 & $8.09 \mathrm{E}-02$ & $4.26 \mathrm{E}-01$ \\
\hline Americium- 241 & 250512-Waste-1 & $5.20 \mathrm{E}-02$ & $1.34 \mathrm{E}-01$ \\
\hline Cerium-144 & 250512-Waste-1 & $1.19 \mathrm{E}-01$ & $3.38 \mathrm{E}-01$ \\
\hline Cobalt-60 & 250512-Waste-1 & $3.42 \mathrm{E}-02$ & $9.57 \mathrm{E}-02$ \\
\hline Cesium-134 & 250512-Waste-1 & $-1.12 \mathrm{E}-02$ & $1.13 \mathrm{E}-01$ \\
\hline Cesium-137 & 250512-Waste-1 & $1.13 \mathrm{E}+00$ & $1.24 \mathrm{E}-01$ \\
\hline Europium-152 & 250512-Waste-1 & $1.08 \mathrm{E}-01$ & $5.00 \mathrm{E}-01$ \\
\hline Europium-154 & 250512-Waste-1 & $-4.68 \mathrm{E}-02$ & 7.03E-01 \\
\hline Europium-155 & 250512-Waste-1 & $7.05 \mathrm{E}-02$ & $1.96 \mathrm{E}-01$ \\
\hline Potassium-40 & 250512-Waste-1 & $7.02 \mathrm{E}-01$ & $1.65 \mathrm{E}+00$ \\
\hline Lead-212 & 250512-Waste-1 & $8.39 \mathrm{E}-02$ & $1.70 \mathrm{E}-01$ \\
\hline Promethium-144 & 250512-Waste-1 & $-3.77 \mathrm{E}-02$ & $1.26 \mathrm{E}-01$ \\
\hline Promethium-146 & 250512-Waste-1 & 4.92E-02 & $1.51 \mathrm{E}-01$ \\
\hline Ruthenium-106 & 250512-Waste-1 & $3.45 \mathrm{E}-01$ & $9.59 \mathrm{E}-01$ \\
\hline Antimony-125 & 250512-Waste-1 & $9.27 \mathrm{E}-02$ & $2.92 \mathrm{E}-01$ \\
\hline Thorium-234 & 250512-Waste-1 & $1.98 \mathrm{E}-01$ & $9.87 \mathrm{E}-01$ \\
\hline Uranium-235 & 250512-Waste-1 & $1.38 \mathrm{E}-01$ & $4.48 \mathrm{E}-01$ \\
\hline Yttrium-88 & 250512-Waste-1 & $-1.21 \mathrm{E}-02$ & $1.14 \mathrm{E}-01$ \\
\hline Actinium-228 & 250512-Waste-2 & $1.31 \mathrm{E}+00$ & $6.64 \mathrm{E}-01$ \\
\hline Americium- 241 & 250512-Waste-2 & $-3.34 \mathrm{E}-01$ & $5.44 \mathrm{E}-01$ \\
\hline Cerium-144 & 250512-Waste-2 & $2.07 \mathrm{E}-01$ & $5.89 \mathrm{E}-01$ \\
\hline Cobalt-60 & 250512-Waste-2 & $-3.35 \mathrm{E}-02$ & $1.53 \mathrm{E}-01$ \\
\hline Cesium-134 & 250512-Waste-2 & $-1.01 \mathrm{E}-01$ & $2.19 \mathrm{E}-01$ \\
\hline Cesium-137 & 250512-Waste-2 & $2.13 \mathrm{E}-01$ & $1.42 \mathrm{E}-01$ \\
\hline
\end{tabular}


TABLE 1 - WASTE CHARACTERIZATION SAMPLE RESULTS (Continued)

\begin{tabular}{|c|c|c|c|}
\hline $\begin{array}{l}\text { PARAMETER } \\
\text { (GAMMA } \\
\text { SPECTROSCOPY) }\end{array}$ & SAMPLE ID & $\operatorname{RESULT}(\mathrm{pCi} / \mathrm{g})^{\mathrm{g}}$ & $\operatorname{MDC}^{f}(p C i / g)^{g}$ \\
\hline Europium-152 & 250512-Waste-2 & $-1.91 \mathrm{E}-01$ & $8.11 \mathrm{E}-01$ \\
\hline Europium-154 & 250512-Waste-2 & $-8.14 \mathrm{E}-02$ & $8.62 \mathrm{E}-01$ \\
\hline Europium-155 & 250512-Waste-2 & $9.49 \mathrm{E}-02$ & $3.57 \mathrm{E}-01$ \\
\hline Potassium-40 & 250512-Waste-2 & $2.61 \mathrm{E}+01$ & $2.42 \mathrm{E}+00$ \\
\hline Lead-212 & 250512-Waste-2 & $1.26 \mathrm{E}+00$ & $2.51 \mathrm{E}-01$ \\
\hline Promethium-144 & 250512-Waste-2 & $1.07 \mathrm{E}-02$ & $1.44 \mathrm{E}-01$ \\
\hline Promethium-146 & 250512-Waste-2 & $6.35 \mathrm{E}-02$ & $1.40 \mathrm{E}-01$ \\
\hline Ruthenium-106 & 250512-Waste-2 & $-4.97 \mathrm{E}-01$ & $1.35 \mathrm{E}+00$ \\
\hline Antimony-125 & 250512-Waste-2 & $-8.62 \mathrm{E}-02$ & $3.23 \mathrm{E}-01$ \\
\hline Thorium-234 & 250512-Waste-2 & $6.17 \mathrm{E}-01$ & $1.67 \mathrm{E}+00$ \\
\hline Uranium-235 & 250512-Waste-2 & 4.69E-02 & $6.39 \mathrm{E}-01$ \\
\hline Yttrium-88 & 250512-Waste-2 & $-7.28 \mathrm{E}-02$ & $1.81 \mathrm{E}-01$ \\
\hline \multicolumn{4}{|c|}{$\begin{array}{l}\text { a } \mathrm{mg} / \mathrm{kg} \text { - milligrams per kilogram } \\
\text { b TPH - Total Petroleum Hydrocarbons } \\
{ }^{\mathrm{c}} \text { TCLP VOC - Toxicity Characteristic Leaching Procedure Volatile Organic Compounds (EPA, 1996) } \\
{ }^{\mathrm{m}} \mathrm{mg} / \mathrm{L}-\text { milligrams per liter } \\
\mathrm{e} \mathrm{pCi} / \mathrm{L}-\text { picoCuries per liter } \\
{ }^{\mathrm{f}} \mathrm{MDC} \text { - Minimum Detectable Concentration } \\
{ }^{\mathrm{p}} \mathrm{pCi} / \mathrm{g} \text { - picoCuries per gram }\end{array}$} \\
\hline
\end{tabular}


The distribution box and a diversion drum were also filled with approximately $4.5 \mathrm{~m}^{3}\left(6 \mathrm{yd}^{3}\right)$ of grout. Two valve boxes and three subsurface vaults within the leachfield were backfilled with clean fill.

To limit erosion of the surface cap, existing surface washes on the southwest and northeast sides of the leachfield were graded and backfilled with geotextile fabric, graded sand, and a minimum of $0.3 \mathrm{~m}(1 \mathrm{ft})$ of rip rap. A rip-rap lined channel was constructed along the north upgradient side of the leachfield to divert overland flow away from the leachfield cap. As-built drawings of the site are presented in Appendix F. A Use Restriction was implemented to restrict intrusive activity into or beneath the site and warning signs were posted on all four sides of the fence. Use Restriction information is presented in Appendix G.

\subsubsection{CAS 25-05-05, Leachfield}

This site consists of a septic tank and was closed by clean closure. Prior to closure activities, waste characterization samples of the tank contents were collected to verify the COC present. The samples were analyzed for TPH full scan, Toxicity Characteristic Leaching Procedure volatile organic compounds (U.S. Environmental Protection Agency [EPA], 1996), gross alpha/beta, and gamma emitting radionuclides. The results indicated that the waste contained TPH above the action level (NAC, 2002a) (see Table 1). Analytical data is presented in Appendix B.

The tank was clean closed by removing, solidifying, and disposing of the tank contents. The contents were pumped out of the tank into a lined basin and solidified with clean soil. When pumping became ineffective due to the viscosity of the sludge, the top of the tank was exposed and opened and the sludge was solidified in place with clean soil. The solidified waste was removed from the tank using appropriate heavy equipment and placed in the lined basin. The tank was pressure washed/steam cleaned to remove any remaining residue in the tank. The final rinseate was sampled to verify that no COC remained in the tank. The rinseate was analyzed for TPH full scan and gross alpha/beta. The results indicated that no COC above action levels remained in the tank (see Table 2). Rinseate remaining in the tank was solidified in place with clean soil and the remaining void space was filled with grout. The excavation was then backfilled with clean fill. In addition, the distribution box and three manholes were also filled with grout. Approximately $25 \mathrm{~m}^{3}\left(33 \mathrm{yd}^{3}\right)$ of grout was used to fill these structures.

The solidified tank contents were disposed in the NTS Area 6 Hydrocarbon Landfill. Approximately $122 \mathrm{~m}^{3}\left(160 \mathrm{yd}^{3}\right)$ of waste was disposed. Per the request of BN SWO, the waste was sampled prior to disposal. The samples were analyzed for gross alpha/beta and gamma emitting radionuclides. The results indicated that the waste met landfill requirements for radiological constituents. The sample results are presented in Table 1 and the analytical data is included in Appendix B. 
TABLE 2 - VERIFICATION SAMPLE RESULTS

\begin{tabular}{|c|c|c|c|}
\hline PARAMETER & SAMPLE ID & $\operatorname{RESULT}(\mu \mathrm{g} / \mathrm{L})^{\mathrm{a}}$ & $\begin{array}{l}\text { REPORTING LIMIT } \\
(\mu \mathrm{g} / \mathrm{L})^{\mathrm{a}}\end{array}$ \\
\hline \multicolumn{4}{|c|}{ CAS 25-05-05 } \\
\hline $\mathrm{TPH}^{\mathrm{b}}$ Diesel & 250505-V1 & 340 & 300 \\
\hline TPH Gasoline & $250505-\mathrm{V} 1$ & $<30$ & 30 \\
\hline TPH Oil & 250505-V1 & 590 & 300 \\
\hline \multicolumn{4}{|c|}{ CAS 25-05-12 } \\
\hline TPH Diesel & 250512-V1 & 300 & 300 \\
\hline TPH Gasoline & 250512-V1 & $<30$ & 30 \\
\hline TPH Oil & 250512-V1 & 340 & 300 \\
\hline TPH Diesel & $250512-V 2^{\mathrm{c}}$ & 300 & 300 \\
\hline TPH Gasoline & 250512-V2 & $<30$ & 30 \\
\hline TPH Oil & 250512-V2 & 300 & 300 \\
\hline PARAMETER & SAMPLE ID & $\begin{array}{l}\text { RESULT } \\
(\mathrm{pCi} / \mathrm{L})^{\mathrm{d}}\end{array}$ & $\operatorname{MDA}^{\mathrm{e}}(\mathbf{p C i} / \mathbf{L})^{\mathrm{d}}$ \\
\hline \multicolumn{4}{|c|}{ CAS 25-05-05 } \\
\hline Gross alpha & 250505-V1 & 3.30 & 3.78 \\
\hline Gross beta & 250505-V1 & 5.42 & 1.50 \\
\hline
\end{tabular}

${ }^{a} \mu \mathrm{g} / \mathrm{L}$ - micrograms per liter

${ }^{\mathrm{b}} \mathrm{TPH}$ - Total Petroleum Hydrocarbons

${ }^{c}$ duplicate of 250512-V1

${ }^{\mathrm{d}} \mathrm{pCi} / \mathrm{L}$ - picoCuries per liter

${ }^{\mathrm{e}}$ MDA - Minimum Detectable Activity 


\subsubsection{CAS 25-05-06, Leachfield}

This CAS is comprised of a leachfield that contains underground radiological $\mathrm{COC}(\mathrm{NNSA} / \mathrm{NV}, 2001)$. The leachfield was closed by closure in place with administrative controls. Closure activities began with filling the distribution box with approximately $7.5 \mathrm{~m}^{3}\left(10 \mathrm{yd}^{3}\right)$ of grout. The leachfield monitoring tubes were cut off at ground level and filled with grout.

The cut tubes were found not to be radiologically impacted and were disposed in the NTS Area 9 Construction Landfill. The radiological survey reports are included in Appendix D and Waste Disposition Records are presented in Appendix E. After the tubes were cut and filled a $2.1 \mathrm{~m} \mathrm{(7}$ $\mathrm{ft}$ ) high chain link security fence was installed around the perimeter of the leachfield. The existing fence was removed and disposed in the NTS Area 9 Construction Landfill. A Use Restriction was implemented to restrict intrusive activity into or beneath the leachfield site and warning signs posted on all four sides of the fence. Use Restriction information is presented in Appendix G.

\subsubsection{CAS 25-05-08, Radioactive Leachfield}

This CAS was closed by closure in place with administrative controls. A 0.6-1.2 $\mathrm{m}(2-4 \mathrm{ft})$ thick soil cap was constructed over the leachfield footprint. The cap was constructed of six $0.2 \mathrm{~m}$ (8 in.) lifts of clean, native soil. Each lift was compacted to at least 90 percent of the maximum density of the fill material. A minimum of four compaction tests were done per lift. Supplemental lifts required a minimum of one compaction test. The compaction tests were conducted in the field by BN MTL personnel and the results are included in Appendix C.

Prior to installing the soil cap, all the leachfield monitoring tubes were cut off at ground level and filled with grout. The cut tubes were found to be radiologically impacted and were copackaged with the CAU 113 waste stream for disposal as low level waste. This was done with the approval of BN Waste Generator Services. The radiological survey reports are presented in Appendix D and Waste Disposition Records are presented in Appendix E.

The buried distribution box was exposed and filled with approximately $4 \mathrm{~m}^{3}\left(5 \mathrm{yd}^{3}\right)$ of grout. The distribution box excavation was backfilled prior to installing the leachfield cap.

To protect the downgradient southern face of the cap from erosion, a cellular confinement system was installed along the downgradient face of the cap. The cells were anchored to the cap with "J hooks and then filled with graded aggregate. After the soil cap was completed, a

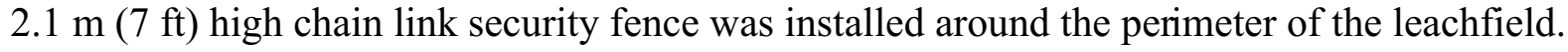
The existing rope fence was removed and disposed in the NTS Area 9 Construction Landfill. As-built drawings for the cover and fence are presented in Appendix F. A Use Restriction was implemented to restrict intrusive activity into or beneath the site and warning signs were posted on all four sides of the fence. Use restriction information is presented in Appendix G.

\subsubsection{CAS 25-05-12, Leachfield}

This site consists of a septic tank and was closed by clean closure. Prior to closure activities, 
waste characterization samples of the tank contents were collected to verify the COC present. The samples were analyzed for TPH full scan, gross alpha/beta, and gamma emitting radionuclides. The results indicated that the waste contained TPH above the action level (NAC, 2002a) (see Table 1). Analytical data is presented in Appendix B.

The tank was clean closed by removing, solidifying, and disposing of the tank contents. The contents were pumped out of the tank into a lined basin and solidified with clean soil. When pumping became ineffective due to the viscosity of the sludge, the top of the tank was exposed and opened, and the sludge was solidified in place with clean soil. The solidified waste was removed from the tank and placed in the lined basin using appropriate heavy equipment. The tank was pressure washed/steam cleaned to remove any remaining residue in the tank. The final rinseate was sampled to verify that no COC remained in the tank. The rinseate was analyzed for TPH full scan. The results indicated no COC above action levels remained in the tank (see Table 2). Rinseate remaining in the tank was solidified in place with clean soil and the remaining void space was filled with grout. The excavation was then backfilled with clean fill. In addition, two system manholes were also filled with grout. Approximately $20 \mathrm{~m}^{3}\left(26 \mathrm{yd}^{3}\right)$ of grout was used to fill the septic tank and two manholes.

The solidified tank contents were disposed in the NTS Area 6 Hydrocarbon Landfill. Approximately $111 \mathrm{~m}^{3}\left(145 \mathrm{yd}^{3}\right)$ of waste was disposed. Per the request of BN SWO, the waste was sampled prior to disposal. The samples were analyzed for gross alpha/beta and gamma emitting radionuclides. The results indicated that the waste met landfill requirements for radiological constituents. The sample results are presented in Table 1 and the analytical data is included in Appendix B.

\subsubsection{CAS 25-51-01, Dry Well}

No COC were identified for this CAS (NNSA/NV, 2001); therefore, this CAS was closed by taking no further action.

\subsection{DEVIATIONS FROM CORRECTIVE ACTION PLAN AS APPROVED}

The NDEP-approved CAP (NNSA/NV, 2002a) was modified before and during field activities to adjust to unexpected conditions and simplify activities. The following deviations occurred from the approved scope of work as presented in the NDEP-approved CAP (NNSA/NV, 2002a). Approved Records of Technical Change are included in Appendix I.

CAS 25-02-06, Underground Storage Tank:

The CAP calls for the removal of the tank lid to allow access. It was determined in the field that the tank was constructed in place and no removable lid was present. Access to the tank interior was sufficient through the existing four manholes. Because no lid was removed, there was no need to construct a reinforced concrete pad over the tank footprint. 
CAS 25-04-06, Septic System B

The tank contents were to be pumped out of the tank and into the NTS Area 23 Sewage Treatment Facility. Because of BN SWO concerns of depositing excess liquid/sediment into the sewage lagoon, the tank contents were pumped into a lined basin and solidified with clean soil. The solidified material was then disposed in the NTS Area 23 Sanitary Landfill.

CAS 25-04-06, Septic System A and CAS 25-04-07, Septic System

The contents of these septic tanks were to be removed and disposed. It was determined in the field that no liquid or sludge were present in either tank; therefore, the tanks were closed by filling with concrete.

CAS 25-05-03, Leachfield

The CAP indicated that the existing security fence around the leachfield was to be replaced. A pre-field inspection determined that the fence was in good condition and replacement was not necessary. Only minor repairs were required for the fence to meet specifications.

CAS 25-05-05, Leachfield and CAS 25-05-12, Leachfield

Because of the configuration of the septic tanks, it was not possible to mix and remove the tank contents by pumping as specified in the CAP. Therefore the tank tops were opened and the contents were solidified in place with clean fill and then removed using appropriate equipment. The tanks were then pressure washed/steam cleaned. The final rinse water was sampled from the tank rather than pumped out into drums for sampling. When sample results indicated that no COC above action levels remained in the tanks, the remaining rinse water was solidified in place with clean fill material. The remaining void spaces were then filled with concrete.

\subsection{CORRECTIVE ACTION SCHEDULE AS COMPLETED}

The corrective action field activities began in December 2002 and were completed in April 2003. Details of the closure field activities schedule are provided in Table 3.

\subsection{SITE PLAN/SURVEY PLAT}

CAS 25-02-06, 25-05-03, 25-05-06, and 25-05-08 were closed in place with administrative controls (i.e., Use Restrictions). Figures listing the site coordinates for the Use Restrictions are provided in Appendix G. Engineered construction was required for CAS 25-05-03 and 25-05-08. As-built drawings of these CASs are provided in Appendix F. 

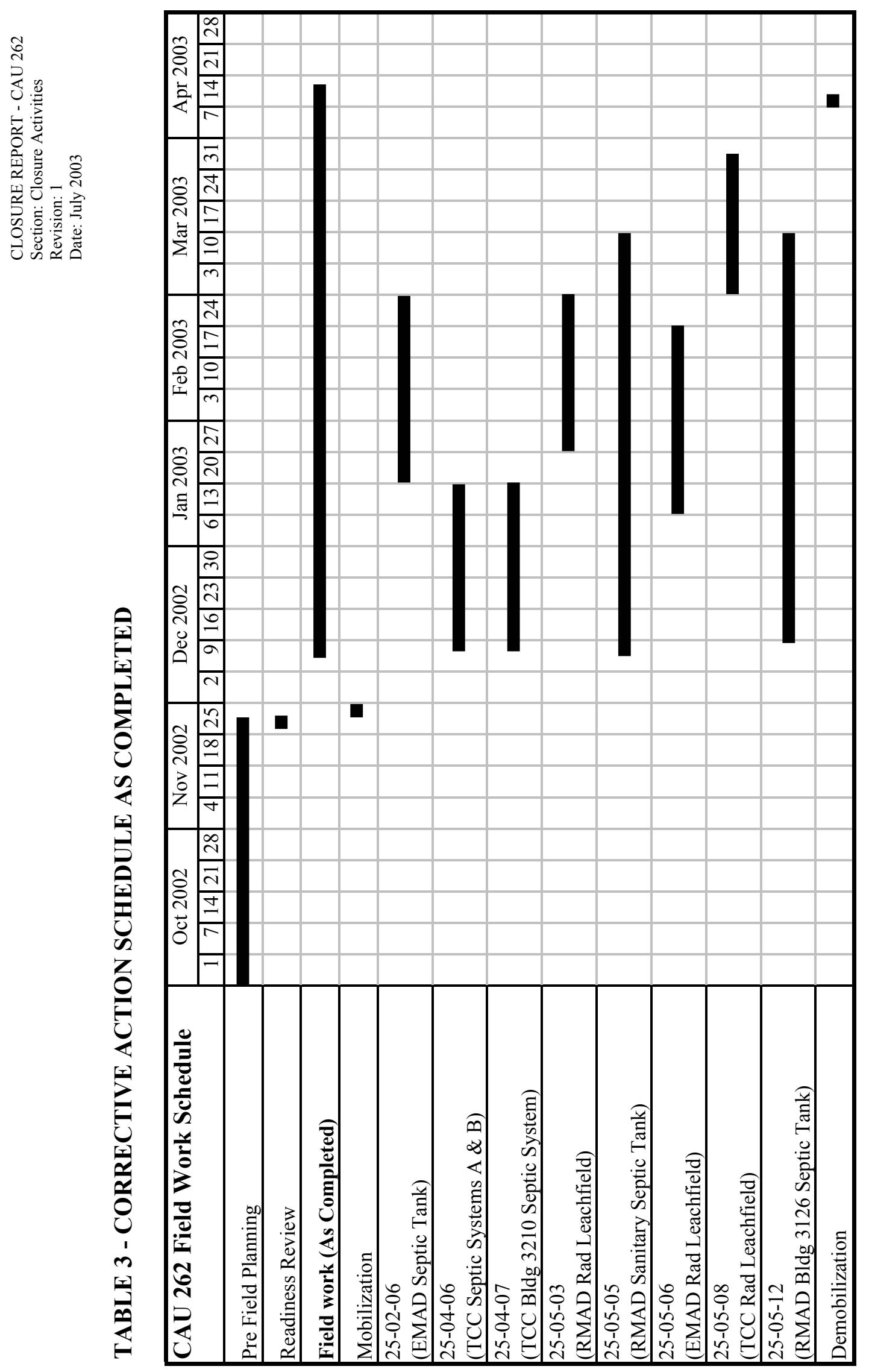


\subsection{WASTE DISPOSITION}

The following types of waste were produced at CAU 262 during closure activities: hydrocarbonimpacted soil and debris, radiologically-impacted pipe, sanitary waste, and construction debris. All waste was managed in accord ance with state and federal regulations, DOE orders, and BN procedures.

During closure activities at CAS 25-05-05, approximately $145 \mathrm{~m}^{3}\left(190 \mathrm{yd}^{3}\right)$ of TPH-impacted soil and debris was removed from the site. This is equivalent to approximately 207,541 kilograms (kgs) $(457,550$ pounds [lbs]) of waste. All of the waste removed from the site was transported and disposed of at the NTS Area 6 Hydrocarbon Landfill and included the solidified septic tank contents, debris, and the solidification basin liner. Waste documentation is provided in Appendix E.

During closure activities at CAS 25-05-12, approximately $111 \mathrm{~m}^{3}\left(145 \mathrm{yd}^{3}\right)$ of TPH-impacted soil and debris was removed from the site. This is equivalent to approximately $143,589 \mathrm{kgs}$ $(316,560 \mathrm{lbs})$ of waste. All of the waste removed from the site was transported and disposed of at the NTS Area 6 Hydrocarbon Landfill and included the solidified septic tank contents, debris, and the solidification basin liner. Waste documentation is provided in Appendix E.

CAS 25-04-06 closure generated approximately $37 \mathrm{~m}^{3}\left(48 \mathrm{yd}^{3}\right)$ of sanitary waste. This is equivalent to approximately $48,367 \mathrm{kgs}(106,630 \mathrm{lbs})$ of waste. The waste was disposed in the NTS Area 23 Sanitary Landfill and included solidified septic tank contents and the solidification basin liner. Waste documentation is provided in Appendix E.

Closure of CAS 25-05-08 generated radiologically-impacted waste. The waste was the leachfield monitoring tubes that were cut off at ground level prior to installing the soil cover. Six $0.6 \mathrm{~m}(2 \mathrm{ft})$ sections of pipe were disposed of. Waste also included hot line trash. Approximately $0.11 \mathrm{~m}^{3}\left(0.15 \mathrm{yd}^{3}\right)$ of waste was generated. This is equivalent to approximately $22.5 \mathrm{kgs}(50 \mathrm{lbs})$ of waste. The cut tubes and hot line trash was co-packaged with the CAU 113 waste stream for disposal as low level radioactive waste. This was done with the approval of BN Waste Generator Services. Waste documentation is provided in Appendix E.

Closure activities at all the CASs generated various miscellaneous construction debris including existing leachfield fence, scrap wood, metal debris, and vegetation. All debris was radiologically surveyed prior to disposal. All debris was found to be free of radiological contamination and was disposed in the NTS Area 9 Construction landfill. Salvageable material such as T-posts were saved for reuse.

A description of the type and quantity of waste generated during CAU 262 closure activities is provided in Table 4. Waste disposition records are included in Appendix E. 
TABLE 4 - WASTE GENERATED DURING CAU 262 CLOSURE ACTIVITIES

\begin{tabular}{|c|c|c|}
\hline WASTE TYPE & $\begin{array}{l}\text { APPROX. WASTE } \\
\text { QUANTITY (mass) }\end{array}$ & $\begin{array}{c}\text { APPROX. WASTE } \\
\text { QUANTITY (volume) }\end{array}$ \\
\hline \multicolumn{3}{|c|}{ CAS 25-05-05 } \\
\hline Petroleum Hydrocarbon & $\begin{array}{l}207,541 \mathrm{kgs}^{\mathrm{a}} \\
\left(457,550 \mathrm{lbs}^{\mathrm{b}}\right)\end{array}$ & $\begin{array}{l}145 \mathrm{~m}^{3 \mathrm{c}} \\
\left(190 \mathrm{yd}^{3}\right)^{\mathrm{d}}\end{array}$ \\
\hline \multicolumn{3}{|c|}{ CAS 25-05-12 } \\
\hline Petroleum Hydrocarbon & $\begin{array}{l}143,589 \mathrm{kgs} \\
(316,560 \mathrm{lbs})\end{array}$ & $\begin{array}{l}111 \mathrm{~m}^{3} \\
\left(145 \mathrm{yd}^{3}\right)\end{array}$ \\
\hline \multicolumn{3}{|c|}{ CAS 25-04-06 } \\
\hline Sanitary & $\begin{array}{l}48,367 \mathrm{kgs} \\
(106,630 \mathrm{lbs})\end{array}$ & $\begin{array}{l}37 \mathrm{~m}^{3} \\
\left(48 \mathrm{yd}^{3}\right)\end{array}$ \\
\hline \multicolumn{3}{|c|}{ CAS 25-05-08 } \\
\hline Low-level Radioactive & $\begin{array}{l}22.5 \mathrm{kgs} \\
(50 \mathrm{lbs})\end{array}$ & $\begin{array}{l}0.11 \mathrm{~m}^{3} \\
\left(0.15 \mathrm{yd}^{3}\right)\end{array}$ \\
\hline \multicolumn{3}{|c|}{ All CASs } \\
\hline Construction Debris & $\begin{array}{l}31,470 \mathrm{kgs} \\
(69,380 \mathrm{lbs})\end{array}$ & $\begin{array}{l}37 \mathrm{~m}^{3} \\
\left(48 \mathrm{yd}^{3}\right)\end{array}$ \\
\hline
\end{tabular}

\footnotetext{
${ }^{a} \mathrm{kgs}$ - kilograms

${ }^{\mathrm{b}}$ lbs - pounds

${ }^{c} \mathrm{~m}^{3}$ - cubic meters

${ }^{\mathrm{d}} \mathrm{yd}^{3}$ - cubic yards
} 


\subsection{CLOSURE VERIFICATION RESULTS}

CAU 262 closure was verified by:

CAS 25-02-06: Closure was accomplished by filling the septic tank, distribution box, and manhole with grout. Because this CAS was closed by closure in place with administrative controls, no verification samples were required.

CAS 25-05-06: Closure in place with administrative controls was completed by

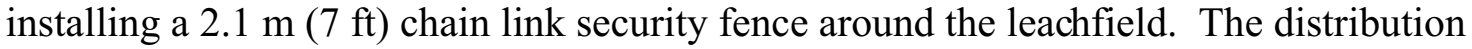
box and monitoring tubes were filled with grout.

CAS 25-05-05: A verification sample of the final rinse water was collected from the septic tank. The sample was analyzed for TPH full scan and gross alpha/beta emitting radionuclides. Verification sample results showed no COC present in the tank above regulatory limits. Sample results are shown in Table 2 and the laboratory data packages are presented in Appendix B. Closure was completed by filling the septic tank, distribution box, and three manholes with grout.

CAS 25-05-12: A verification sample of the final rinse water was collected from the septic tank. The sample was analyzed for TPH full scan. Verification sample results showed no COC present in the tank above regulatory limits. Sample results are shown in Table 2 and the laboratory data packages are presented in Appendix B. Closure was completed by filling the septic tank and two manholes with grout.

CAS 25-04-06 System B: Closure was accomplished by removing and disposing the tank contents. Because the contents were sanitary waste only, no verification samples were required. The septic tank, distribution box, and manhole were filled with grout.

CAS 25-04-06 System A: Because no contents were present in the tank, closure was achieved by filling the septic tank, distribution box, and manhole with grout.

CAS 25-04-07: Because no contents were present in the tank, closure was achieved by filling the septic tank, distribution box, and manhole with grout.

CAS 25-05-03 and 25-05-08: Construction of the soil covers and erosion control structures as designed were verified by As-built drawings. (Appendix F).

CAS 25-51-01: No COC were identified for this CAS (NNSA/NV, 2001); therefore, this CAS was closed by taking no further action.

All verification samples were collected with disposable polyethylene dippers and placed in appropriately labeled sample containers secured with custody seals. All samples were labeled with a unique sample number, placed on ice in coolers, and transported under chain-of-custody to an off-site laboratory. All samples were analyzed for TPH full scan. 
During collection of all verification samples, standard quality assurance/quality control (QA/QC) samples were also collected; e.g., one field duplicate per 20 samples submitted blind to the analytical laboratory for analysis. Also, the analytical laboratory followed standard QA/QC procedures during sample analysis. This included matrix spike/matrix spike duplicate and spiked surrogate percent recovery analysis (Appendix B).

\subsection{DATA QUALITY ASSESSMENT}

CAU 262 closure activities were performed to the criteria specified in the NDEP-approved CAP (NNSA/NV, 2002a) and CADD (NNSA/NV, 2001). The approved correction action alternatives as implemented did not result in any deviations with the conceptual model as presented in the CAIP (DOE/NV, 2000) and included in Appendix A of this report.

The closure in place with administrative controls alternative included constructing engineered soil covers and filling septic tanks with grout. No verification data were required, therefore, agreement with the conceptual model was determined by the results of characterization activities (NNSA/NV, 2001).

Clean closure of the septic tanks at CAS 25-05-05 and 25-05-12 required removal of the tank contents. Verification samples were required at these CASs because the septic tanks contained COC above action levels. Verification samples were limited to the tank interiors and not the surrounding soil. However, during removal of the tank contents, visual inspections did not indicate any cracks, holes, or other structural defects. This qualitative data coincides with data gathered during characterization, which indicated no contamination in the soil caused by a septic tank breach.

\subsection{USE RESTRICTIONS}

Use restrictions have been implemented at the following four CASs: 25-02-06, 25-05-03, 25-05-06, and 25-05-08. CASs 25-04-06, 25-04-07, 25-05-05, and 25-05-12 have been cleanclosed; use of the areas associated with these sites is unrestricted. CAS 25-51-01 was closed by taking no further action; future use of this area is unrestricted. Use Restriction information is provided in Appendix G.

A risk assessment for the following four CASs was made based on the "A through $\mathrm{K}$ evaluation as presented in NAC Section 445A.227 (NAC, 2002b). The results of the "A through K evaluation are found in the CADD (NNSA/NV, 2001) and are included in Appendix J of this report.

\subsubsection{CAS 25-02-06, Underground Storage Tank Use Restriction}

COC associated with this CAS are confined within the septic tank; therefore, the use restriction was implemented as the boundaries of the tank itself. Two Use Restriction warning signs were erected in the area as specified in the CAP (NNSA/NV, 2002a). 
The Use Restriction Information form and a figure showing the location of the corner points for the area at CAS 25-02-06 are contained in Appendix G.

\subsubsection{CAS 25-05-03, Leachfield Use Restriction}

This site contains underground radioactive material. Closure activities included the installation

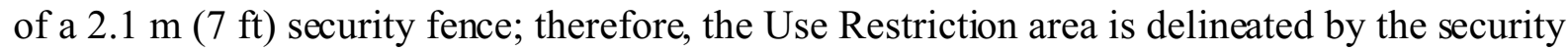
fence. Survey located the four corner fence posts bounding the leachfield. The Use Restriction Information form and figure showing the location of the corner points for CAS 25-05-03 is contained in Appendix G.

\subsubsection{CAS 25-05-06, Leachfield Use Restriction}

This site contains underground radioactive material. Closure activities included the installation

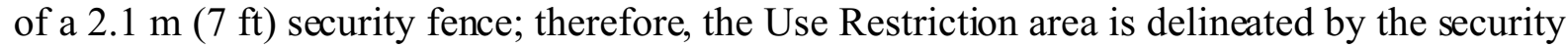
fence. Survey located the four corner fence posts bounding the leachfield. The Use Restriction Information form and figure showing the location of the corner points for CAS 25-05-06 is contained in Appendix G.

\subsubsection{CAS 25-05-08, Radioactive Leachfield}

This site contains underground radioactive material. Closure activities included the installation

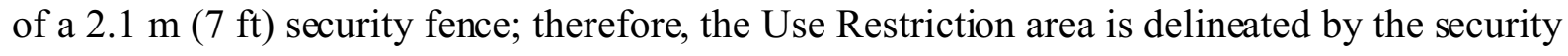
fence. Survey located the corner fence posts bounding the leachfield. The Use Restriction Information form and figure showing the location of the corner points for CAS 25-05-08 is contained in Appendix G. 
CLOSURE RE PORT - CAU 262

Section: Closure Verification

Revision : 1

Date: July 2003

THIS PAGE INTENTIONALLY LEFT BLANK 


\subsection{CONCLUSIONS AND RECOMMENDATIONS}

\subsection{CONCLUSIONS}

The following site closure activities were performed at CAU 262 and are documented in this CR.

CAS 25-02-06 was closed in place by solidifying the septic tank contents and filling the remaining void space with grout. Access points were also filled with grout. A use restriction was implemented to restrict access into the tank.

CAS 25-04-06 consists of two septic systems (A and B). System A septic tank contained no liquid or sludge and was clean closed by filling the septic tank, distribution box, and upstream manhole with grout. System B was clean closed by removing and disposing the septic tank contents, and the tank, distribution box, and upstream manhole were filled with grout.

CAS 25-04-07 septic tank and distribution box contained no liquid or sludge and was clean closed by filling with grout.

CAS 25-05-03 is a leachfield which was closed in place with administrative controls by installing a $0.6 \mathrm{~m}(2 \mathrm{ft})$ thick soil cap over the leachfield. As a best management practice to control potential erosion, existing surface washes were graded and backfilled with rip rap. A riprap lined channel was constructed along the upgradient side of the leachfield to divert overland flow away from the leachfield cap. The existing chain link fence was repaired and permanent warning signs were affixed to the fence. A use restriction was implemented to restrict intrusive activity into or beneath the site.

CAS 25-05-05 septic tank was clean closed by removing, solidifying, and disposing the tank contents. The tank was pressure washed/steam cleaned and the rinseate was sampled to verify that no COC remained in the tank. The tank, distribution box, and access points were filled with grout and the excavation was backfilled with clean fill material.

CAS 25-05-06 is a leachfield that was closed in place with administrative controls by installing a

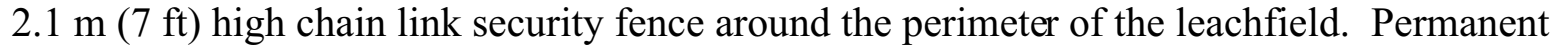
warning signs were affixed to the fence and a Use Restriction was implemented to restrict intrusive activity into the leachfield.

CAS 25-05-08 is a leachfield that was closed in place with administrative controls installing a $1.2 \mathrm{~m}(4 \mathrm{ft})$ thick soil cap over the leachfield. The existing fence was removed and disposed and

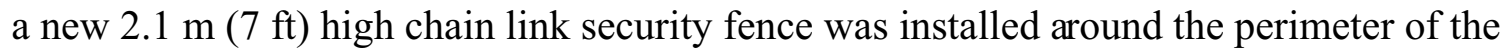
leachfield. As a best management practice to control potential erosion, a cellular confinement system filled with aggregate was installed on the downgradient face of the cap. Permanent warning signs were affixed to the new fence and a use restriction was implemented to restrict intrusive activity into or beneath the site. 
CAS 25-05-12 septic tank was clean closed by removing, solidifying, and disposing the tank contents. The tank was pressure washed/steam cleaned and the rinseate was sampled to verify that no COC remained in the tank. The tank, distribution box and access points were filled with grout and the excavation was backfilled with clean fill material.

CAS 25-51-01 is an underground discharge point that was closed by taking no further action.

\subsection{POST-CLOSURE MONITORING REQUIREMENTS}

Details of the CAU 262 post-closure monitoring plan are provided below:

\subsubsection{Inspections}

\subsubsection{CAS 25-02-06}

The inspection will be performed on an annual basis and will consist of visual observations to verify that the proper signs are in place and readable, and that the use restriction is maintained. If any maintenance and repair requirements are identified, funding will be requested and the repairs scheduled. Any repairs will be documented in writing at the time of repair.

\subsubsection{CAS 25-05-03}

The inspection will be performed on an annual basis and will consist of visual observations to verify that the fence is in good condition, proper signs are in place and readable, the soil cover is intact, and the use restriction is maintained. If any maintenance and repair requirements are identified, funding will be requested and the repairs scheduled. Any repairs will be documented in writing at the time of repair.

\subsubsection{CAS 25-05-06}

The inspection will be performed on an annual basis and will consist of visual observations to verify that the fence is in good condition, proper signs are in place and readable, and the use restriction is maintained. If any maintenance and repair requirements are identified, funding will be requested and the repairs scheduled. Any repairs will be documented in writing at the time of repair.

\subsubsection{CAS 25-05-08}

The inspection will be performed on an annual basis and will consist of visual observations to verify that the fence is in good condition, proper signs are in place and readable, the soil cover is intact, and the use restriction is maintained. If any maintenance and repair requirements are identified, funding will be requested and the repairs scheduled. Any repairs will be documented in writing at the time of repair. 
The post-closure inspections will consist of detailed inspections of the fence, soil covers as applicable, and postings. Inspection results will be documented in a single annual letter report. The letter report will include a discussion of observations and provide a record of maintenance activities. A copy of each annual letter report will be submitted to the NDEP.

The proposed date for the first post-closure inspection is May 2004 and the proposed due date for the post-closure monitoring report is approximately one year after the NDEP approves the final CAU $262 \mathrm{CR}$.

\subsection{RECOMMENDATIONS}

Based on completion of site closure activities as documented by this $\mathrm{CR}$, it is requested that a Notice of Completion be provided by the NDEP for CAU 262. Upon closure approval, CAU 262 will be promoted from Appendix III to Appendix IV of the FFACO (1996), "Closed Corrective Action Units. 
CLOSURE RE PORT - CAU 262

Section: Conclusions \& Recom.

Revision : 1

Date: July 2003

THIS PAGE INTENTIONALLY LEFT BLANK 


\subsection{REFERENCES}

BN, see Bechtel Nevada.

Bechtel Nevada, 2001a. Field Management Plan for Corrective Action Unit 262: Area 25 Septic Systems and Underground Discharge Point, Nevada Test Site, Nevada, Las Vegas, NV.

Bechtel Nevada, 2001b. Site-Specific Health and Safety Plan for Corrective Action Unit 262: Area 25 Septic Systems and Underground Discharge Point, Nevada Test Site, Nevada, Las Vegas, NV.

DOE/NV, see U.S. Department of Energy, Nevada Operations Office.

EPA, see U.S. Environmental Protection Agency

FFACO, see Federal Facility Agreement and Consent Order.

Federal Facility Agreement and Consent Order of 1996 (as amended). Agreed to by the State of Nevada, U.S. Department of Energy, and U.S. Department of Defense.

NAC, see Nevada Administrative Code.

Nevada Administrative Code. 2002a. Section 445A.2272, "Contamination of Soil: Establishment of Action Levels. Carson City, NV.

Nevada Administrative Code. 2002b. Section 445A.227, "Contamination of Soil: Order by Director for Corrective Action; Factors to be Considered in Determining Whether Corrective Action is Required. Carson City, NV.

NNSA/NV, see U.S. Department of Energy, National Nuclear Security Administration Nevada Operations Office

U.S. Department of Energy, National Nuclear Security Administration Nevada Operations Office, 2002a. Corrective Action Plan for Corrective Action Unit 262: Area 25 Septic Systems and Underground Discharge Point, Nevada Test Site, Nevada; Revision 0, DOE/NV--824, Las Vegas, NV.

U.S. Department of Energy, National Nuclear Security Administration Nevada Operations Office Nevada Operations Office, 2002b. Nevada Environmental Restoration Project, Industrial Sites Quality Assurance Project Plan, Nevada Test Site, Nevada, DOE/NV-372-Rev. 3, Las Vegas, NV.

U.S. Department of Energy, National Nuclear Security Administration Nevada Operations Office Nevada Operations Office, 2001. Corrective Action Decision Document for Corrective Action Unit 262: Area 25 Septic Systems and Underground Discharge Point, Nevada Test Site, Nevada; Revision 1, DOE/NV--744, Las Vegas, NV. 
CLOSURE RE PORT - CAU 262

Section: References

Revision : 1

Date: July 2003

U.S. Department of Energy, Nevada Operations Office, 2000. Corrective Action Investigation Plan for Corrective Action Unit 262: Area 25 Septic Systems and Underground Discharge Point, Nevada Test Site, Nevada; Revision 0, DOE/NV 629, Las Vegas, NV.

U.S. Environmental Protection Agency. 1996. Test Methods for Evaluating Solid Waste, Physical/Chemical Methods, EPA Publication SW-846, Third Edition. Washington, D.C. 


\section{APPENDIX A}

\section{DATA QUALITY OBJECTIVES FOR CAU 262*}

* As presented and published in the approved Corrective Action Investigation Plan for Corrective Action Unit 262: Area 25 Septic Systems and Underground Discharge Point, Nevada Test Site, Nevada, July 2000, DOE/NV--629, Rev. 0. Las Vegas, NV. 
CLOSURE RE PORT - CAU 262

Section: Appendix A

Revision : 1

Date: July 2003

THIS PAGE INTENTIONALLY LEFT BLANK 


\begin{tabular}{ll} 
ACRONYMS AND ABBREVIATIONS \\
\hline bgs & Below ground surface \\
BMEC & Burns \& McDonnell Engineering Company \\
BN & Bechtel Nevada \\
CADD & Corrective Action Decision Document \\
CAIP & Corrective Action Investigation Plan \\
CAS & Corrective Action Site(s) \\
CAU & Corrective Action Unit(s) \\
COPC & Contaminant(s) of potential concern \\
CR & Closure Report \\
CV & Coefficient of variation \\
DoD & U.S. Department of Defense \\
DOE & U.S. Department of Energy \\
DOE/NV & U.S. Department of Energy, Nevada Operation Office \\
DQO & Data Quality Objective(s) \\
E-MAD & Engine-Maintenance Assembly and Disassembly \\
EPA & U.S. Environmental Protection Agency \\
r $_{\mathrm{r}}$ & percent error \\
FFACO & Federal Facility Agreement and Consent Order \\
FSL & Field-screening levels \\
ft & Foot (feet) \\
FMBF & Flatow, More, Bryan and Fairburn \\
in. & Inch(es) \\
IT & International Technology Corporation \\
LASL & Los Alamos Scientific Laboratory \\
NAC & Nevada Administrative Code \\
NDEP & Nevada Division of Environmental Protection \\
NRDS & Nuclear Rocket Development Station \\
NTS & Nevada Test Site \\
PAL & Preliminary action level(s) \\
PCB & Polychlorinated biphenyl(s) \\
ppm & parts per million \\
PRG & Preliminary Remediation Goal(s) \\
QA/QC & Quality assurance/quality control \\
RCRA & Resource Conservation and Recovery Act \\
REECo & Reynolds Electrical \& Engineering Co., Inc. \\
R-MAD & Reactor-Maintenance Assembly and Disassembly \\
SAIC & Science Application International Corporation \\
SVOC & Semivolatile organic compound(s) \\
TCC & Test Cell C \\
TPH & Total petroleum hydrocarbons \\
UDP & Underground Discharge Point \\
VEC & Vitro Engineering Company \\
VOC & Volatile organic compound(s) \\
&
\end{tabular}


CLOSURE RE PORT - CAU 262

Section: Appendix A

Revision : 1

Date: July 2003

THIS PAGE INTENTIONALLY LEFT BLANK 


\section{A.1.0 Introduction}

\section{A.1.1 Problem Statement}

Potentially hazardous and radioactive wastes were discharged to several leachfields and an UDP in Area 25 addressed as CAU 262, Area 25 Septic Systems and UDP. Corrective Action Sites at the R-MAD, TCC, and E-MAD facilities are included. The four CASs associated with the R-MAD facility are 25-05-03 (Radioactive Leachfield), 25-05-05 (Leachfield), 25-05-12 (Leachfield), and 25-51-01 (Dry Well). The three CASs associated with the Test Cell C facility are 25-04-06 (Septic Systems A and B), 25-04-07 (Septic System), and 25-05-08 (Radioactive Leachfield). The two CASs associated with the E-MAD facility are 25-02-06 (Underground Storage Tank) and 25-05-06 (Leachfield). Existing information about the nature and extent of contamination is insufficient to evaluate and select preferred corrective actions for these sites.

These leachfield systems will be investigated based on DQOs developed by representatives of NDEP and DOE/NV. This investigation will determine if COPCs are present and if concentrations in soils underlying the leachfields and surrounding the leachfield system components exceed regulatory levels. If COPCs are detected, the lateral and vertical extent of contamination will be determined. This investigation will focus on collection of data adequate to close the site under NDEP, RCRA, and DOE requirements.

\section{A.1.2 DQO Kickoff Meeting}

Table A.1-1 lists the participants present at the FFACO-required DQO Kickoff Meeting and any subsequent meetings. The goal of the DQO process is to establish the quantity and quality of environmental data required to support corrective action decisions for the CAU. The process ensures that the information collected will provide sufficient and reliable information to identify, evaluate, and technically defend the chosen corrective action. Unless otherwise required by the results of this DQO and stated in the CAIP, this investigation will adhere to the Industrial Sites Quality Assurance Project Plan (DOE/NV, 1996) and the Work Plan for Leachfield Corrective Action Units: Nevada Test Site and Tonopah Test Range, Nevada (DOE/NV, 1998b), hereafter referred to as the Leachfield Work Plan. 
Table A.1-1

DQO Kickoff Meeting Participants

\begin{tabular}{|c|c|c|c|}
\hline \multirow[b]{2}{*}{ Proposed Participants } & \multirow[b]{2}{*}{ Affiliation } & \multicolumn{2}{|c|}{ Meeting Date } \\
\hline & & $\begin{array}{c}\text { Kickoff Meeting } \\
2 / 1 / 00\end{array}$ & $\begin{array}{c}\text { Pipe Characterization } \\
\text { Meeting }^{\mathrm{a}} \\
3 / 28 / 00\end{array}$ \\
\hline Lydia Coleman & SAIC & $\sqrt{ }$ & \\
\hline Sabine Curtis & DOE/NV & $\sqrt{ }$ & $\sqrt{ }$ \\
\hline Bruce Dionne & IT & $\sqrt{ }$ & \\
\hline Cindy Dutro & IT & $\sqrt{ }$ & \\
\hline Thomas Fitzmaurice & $\mathrm{BN}$ & $\sqrt{ }$ & \\
\hline Dennis Gustafson & $\mathrm{BN}$ & $\sqrt{ }$ & \\
\hline Juliana Herrington & SAIC & $\sqrt{ }$ & \\
\hline Syl Hersh & IT & $\sqrt{ }$ & \\
\hline Mark Holmes & IT & $\sqrt{ }$ & \\
\hline Mike McKinnon & NDEP & $\sqrt{ }$ & $\sqrt{ }$ \\
\hline Jason Moore & SAIC & $\sqrt{ }$ & \\
\hline Charles Orchard & SAIC & $\sqrt{ }$ & \\
\hline Barbara Quinn & $\mathrm{BN}$ & $\sqrt{ }$ & \\
\hline Greg Rabb & NDEP & & $\sqrt{ }$ \\
\hline Milinka Watson-Garrett & IT & $\sqrt{ }$ & \\
\hline Jeanne Wightman & MACTEC & $\sqrt{ }$ & \\
\hline Dustin Wilson & SAIC & $\sqrt{ }$ & $\sqrt{ }$ \\
\hline John Wong & NDEP & $\sqrt{ }$ & \\
\hline
\end{tabular}

${ }^{\mathrm{a}}$ The pipe characterization meeting was conducted to establish Data Quality Objectives for the limited characterization of collection system piping. The results of this meeting have been integrated into this document.

BN - Bechtel Nevada

DOE/NV - U.S. Department of Energy, Nevada Operations Office

IT - IT Corporation

NDEP - Nevada Division of Environmental Protection

SAIC - Science Applications International Corporation 


\section{A.2.0 Conceptual Model}

The CAU 262 Leachfields and UDP received various combinations of sanitary effluent, process effluent and radioactive effluent primarily from operations conducted within associated Area 25 facilities. Dates of leachfield activity are variable and poorly constrained, but the Area 25 facilities were most active between 1959 and 1973. All of the leachfields addressed by CAU 262 are currently inactive or abandoned but some leachfields may still receive effluent from passive generation (i.e., open pad drains, floor drains, and equipment drains).

Within this document, "effluent" is generally applied to all liquid waste disposed of in leachfield systems without regard to toxic, hazardous, or radioactive properties. Effluent discharged to the CAU 262 leachfields is considered potentially contaminated with various constituents but the probabilities of actual contamination are highly variable. "Sanitary effluent" is considered equivalent to domestic sewage and potentially toxic, "process effluent" is considered potentially hazardous and "radioactive effluent" is considered potentially radioactive and hazardous. The three leachfields in CASs 25-05-03, 25-05-06, and 25-05-08 are posted as underground radiological materials areas. "Posted Leachfields" are considered radioactively contaminated.

For each leachfield system, effluent was discharged from source buildings and routed through the collection system to a septic tank and/or distribution box. Subsequent discharge to the leachfield via distribution lines allowed effluent to percolate into the underlying soil for disposal. Effluent contaminants were transported by relatively large volumes of water. This conceptual model is consistent with the general conceptual model for leachfield CAUs provided in Section 3.1 of the Leachfield Work Plan.

An outline of CAU-specific and CAS-specific elements of the conceptual model for CAU 262 is provided in Table A.2-1 and Table A.2-2. 


\section{Table A.2-1 \\ General CAU 262 Conceptual Model \\ (Page 1 of 2)}

\begin{tabular}{|c|c|c|}
\hline $\begin{array}{c}\text { Conceptual Model } \\
\text { Element }\end{array}$ & Assumptions & Source \\
\hline \multirow{3}{*}{$\begin{array}{l}\text { System dynamics, } \\
\text { waste inventories, } \\
\text { release information }\end{array}$} & $\begin{array}{l}\text { Infiltration and concentration of contaminants in the form } \\
\text { of liquid waste into the soil directly below the distribution } \\
\text { pipes and within the leachfields may have occurred. }\end{array}$ & $\begin{array}{l}\text { Knowledge of similar sites, } \\
\text { Leachfield Work Plan } \\
\text { (DOE/NV, 1998b) }\end{array}$ \\
\hline & $\begin{array}{l}\text { Groundwater contamination is unlikely due to } \\
\text { environmental conditions at the sites, such as an arid } \\
\text { climate, low permeabilities, and depth to groundwater }\end{array}$ & $\begin{array}{l}\text { Knowledge of similar sites, } \\
\text { Leachfield Work Plan } \\
\text { (DOE/NV, 1998b) }\end{array}$ \\
\hline & $\begin{array}{l}\text { Driving forces restricted to infiltration of limited } \\
\text { precipitation subsequent to cessation of facility } \\
\text { operations and redirection of generated effluent to } \\
\text { alternative disposal systems. }\end{array}$ & $\begin{array}{l}\text { Knowledge of similar sites, } \\
\text { Leachfield Work Plan } \\
\text { (DOE/NV, 1998b) }\end{array}$ \\
\hline \multirow{2}{*}{$\begin{array}{l}\text { Lateral extent of } \\
\text { potential contaminants }\end{array}$} & Subsurface effects limited by low mobility of constituents. & $\begin{array}{l}\text { Process knowledge and } \\
\text { similar site investigations } \\
\text { (i.e., CAUs } 261 / 266 / 500 \\
\text { [DOE/NV, 1999; } 2000 a \text { a, } \\
2000 \text { b]) }\end{array}$ \\
\hline & $\begin{array}{l}\text { The potential lateral migration of contaminants is } \\
\text { unknown, but if migration has occurred, it will likely be } \\
\text { confined within the boundaries of the leachfield. }\end{array}$ & $\begin{array}{l}\text { Process knowledge and } \\
\text { similar site investigations } \\
\text { (i.e., CAUs } 261 / 266 / 500 \\
\text { [DOE/NV, 1999; 2000a; } \\
2000 \text { b]) }\end{array}$ \\
\hline $\begin{array}{l}\text { Vertical extent of } \\
\text { potential contaminants }\end{array}$ & $\begin{array}{l}\text { The vertical extent of potential contamination is unknown, } \\
\text { but if present, will be primarily adjacent to and below the } \\
\text { distribution lines. Potential contamination is probably } \\
\text { concentrated at the native soil/leachfield material } \\
\text { interface. Vertical extent should be limited by low } \\
\text { mobility of COPCs and limited driving force. }\end{array}$ & $\begin{array}{l}\text { Process knowledge and } \\
\text { similar site investigations } \\
\text { (i.e., CAUs } 261 / 266 / 500 \\
\text { [DOE/NV, 1999; } 2000 a \text {, } \\
\text { 2000b]) }\end{array}$ \\
\hline $\begin{array}{l}\text { Physical and practical } \\
\text { constraints }\end{array}$ & $\begin{array}{l}\text { Radiological control access requirements to posted areas } \\
\text { surrounding posted leachfields (CASs } 25-05-03,-08 \text {, and } \\
\text {-06). Current posting of these leachfields is "Underground } \\
\text { Radioactive Materials Area." } \\
\text { Additional constraints include Yucca Mountain Project } \\
\text { activities; activities of other Area } 25 \text { users (i.e., DoD) } \\
\text { nearby utilities; facility constrains including fencing, } \\
\text { buildings, and concrete pads; adverse weather } \\
\text { conditions; restricted access; heavy equipment and } \\
\text { resource availability; health and safety concerns; } \\
\text { approval of the CAIP. }\end{array}$ & Site knowledge; site visits \\
\hline
\end{tabular}




\section{Table A.2-1 \\ General CAU 262 Conceptual Model}

(Page 2 of 2)

\begin{tabular}{|c|c|c|}
\hline $\begin{array}{c}\text { Conceptual Model } \\
\text { Element }\end{array}$ & Assumptions & Source \\
\hline Future use & $\begin{array}{l}\text { Leachfield systems are contained within restricted use } \\
\text { zones classified as either "Research Test and } \\
\text { Experiment Zone" or "Yucca Mountain Site } \\
\text { Characterization Zone". } \\
\text { The Research Test and Experiment Zone is designated } \\
\text { for small-scale research and development projects and } \\
\text { demonstrations; pilot projects; outdoor tests; and } \\
\text { experiments for development, quality assurance, or } \\
\text { reliability of material and equipment under controlled } \\
\text { conditions. This includes compatible nondefense } \\
\text { research, development and testing projects and } \\
\text { activities. } \\
\text { CASs 25-02-06 and 25-05-06 are contained within the } \\
\text { zone designated for Yucca Mountain Site } \\
\text { Characterization. }\end{array}$ & $\begin{array}{l}\text { Record of Decision Land Use } \\
\text { Zones as defined in NTS } \\
\text { Resource Management Plan, } \\
\text { (DOE/NV, 1998a) }\end{array}$ \\
\hline Potential exposures & $\begin{array}{l}\text { Ingestion, inhalation, external exposure to radiation, or } \\
\text { dermal contact (absorption) of COPCs in the soil due to } \\
\text { exposure during investigation. }\end{array}$ & Process knowledge \\
\hline Waste management & $\begin{array}{l}\text { Waste will be evaluated against characteristic criteria } \\
\text { unless contrary information is discovered during the } \\
\text { investigation. } \\
\text { The following constituents will be considered listed if } \\
\text { identified in samples associated with CAS 25-05-03: } \\
\text { Carbon tetrachloride, Trichloroethylene, 1,1,1- } \\
\text { Trichloroethane, 1,1,2-Tricloro-1,2,2-triflouroethane, and } \\
\text { Tetrachloroethylene. }\end{array}$ & Process knowledge \\
\hline
\end{tabular}


Table A.2-2

CAS-Specific CAU 262 Conceptual Model

(Page 1 of 9 )

\begin{tabular}{|c|c|c|}
\hline $\begin{array}{l}\text { Conceptual Model } \\
\text { Element }\end{array}$ & Assumptions & Source \\
\hline \multicolumn{3}{|c|}{ CAS Facility Association: R-MAD } \\
\hline \multicolumn{3}{|c|}{ CAS 25-05-03 } \\
\hline $\begin{array}{l}\text { System dynamics, } \\
\text { waste inventories, } \\
\text { release information }\end{array}$ & $\begin{array}{l}\text { Radioactive effluent generated within Buildings } 3110 \text {, } \\
3126,3161 \text {, and a radiochemistry trailer was discharged } \\
\text { to this leachfield. The leachfield is located south of the } \\
\text { R-MAD facility and is composed of two distribution } \\
\text { manifolds supplied by a diversion box. Twenty-five } 100-\mathrm{ft} \\
\text { long distribution lines are connected to each distribution } \\
\text { manifold on } 8 \text {-ft centers. The distribution lines are } 6 \text {-in. } \\
\text { diameter open joint tiles installed in an 18-in. wide by } \\
\text { 18-in. high gravel-filled trench and are approximately } 1 \mathrm{ft} \\
\text { bgs. }\end{array}$ & $\begin{array}{l}\text { Engineering drawings } \\
\text { including 25-R-MAD-C1 } \\
\text { (REECo, 1983b), and } \\
3102-S W-6.1 \text { Sheet } 8 \\
\text { (BMEC, 1959) }\end{array}$ \\
\hline \multirow{4}{*}{ Source location } & $\begin{array}{l}\text { Sources within Building 3110: Darkroom sink, drain } \\
\text { trench, hatch frame drain line, laboratory sink, open } \\
\text { drains, floor drains, and showers. }\end{array}$ & \multirow{4}{*}{ Engineering drawings } \\
\hline & $\begin{array}{l}\text { Sources within Building 3126: Acid drains, service sinks, } \\
\text { floor sink, and decontamination sink with filter hood and } \\
\text { exhaust fan. }\end{array}$ & \\
\hline & $\begin{array}{l}\text { Sources within Building } 3161 \text { : Chemistry sink, floor drain, } \\
\text { safety shower, and sink. }\end{array}$ & \\
\hline & Sources within radiochemistry trailer: Unknown. & \\
\hline \multirow[b]{2}{*}{$\begin{array}{l}\text { Contaminants of } \\
\text { Potential Concern }\end{array}$} & $\begin{array}{l}\text { Process and radioactive effluent associated with } \\
\text { assembly, maintenance, and disassembly of nuclear } \\
\text { reactors tested at the NRDS. Additional work after } \\
\text { termination of NRDS program may also have contributed } \\
\text { effluent to this leachfield. }\end{array}$ & \multirow[b]{2}{*}{ Process knowledge } \\
\hline & $\begin{array}{l}\text { Building } 3110 \text { potentially hazardous COPCs identified } \\
\text { during preliminary assessment include: Ethyl alcohol, } \\
\text { ethanol, Freon, PCBs, trichloroethene, and } \\
\text { trichloroethylene. } \\
\text { Radiological COPCs include: Barium-137 m, } \\
\text { cesium-137, cobalt-60, europium-152, niobium-94, } \\
\text { plutonium-239/240, radium-226, strontium-90, } \\
\text { uranium-234, uranium-235, and uranium-238. }\end{array}$ & \\
\hline
\end{tabular}


Table A.2-2

CAS-Specific CAU 262 Conceptual Model

(Page 2 of 9 )

\begin{tabular}{|c|c|c|}
\hline $\begin{array}{l}\text { Conceptual Model } \\
\text { Element }\end{array}$ & Assumptions & Source \\
\hline \multirow{3}{*}{$\begin{array}{l}\text { Contaminants of } \\
\text { Potential Concern }\end{array}$} & $\begin{array}{l}\text { Building } 3126 \text { potentially hazardous COPCs identified } \\
\text { during preliminary assessment include: Carbon } \\
\text { tetrachloride, dilute acid, powdered citric acid in water, } \\
\text { trichloroethene, TPH and unidentified RCRA metals, } \\
\text { VOCs, and SVOCs. } \\
\text { Radiological COPCs include: Barium-137 m, } \\
\text { cesium-137, plutonium isotopes, strontium-90, depleted } \\
\text { uranium, uranium-234, and yttrium-90. }\end{array}$ & \multirow{3}{*}{ Process knowledge } \\
\hline & $\begin{array}{l}\text { Building } 3161 \text { potentially hazardous COPCs identified } \\
\text { during preliminary assessment include: Fuming nitric } \\
\text { acid, perchloric acid, sulfuric acid, and mercury. } \\
\text { Radiological COPCs include: Barium-137m, cesium-137, } \\
\text { cobalt-60, niobium-94, plutonium-239/240, uranium-234, } \\
\text { uranium 238, and yttrium-90. }\end{array}$ & \\
\hline & $\begin{array}{l}\text { COPCs associated with the radiochemistry trailer are } \\
\text { unknown, but potentially hazardous and radioactive. }\end{array}$ & \\
\hline \multicolumn{3}{|c|}{ CAS 25-05-05 } \\
\hline $\begin{array}{l}\text { System dynamics, } \\
\text { waste inventories, } \\
\text { release information }\end{array}$ & $\begin{array}{l}\text { Sanitary and process effluent generated within Buildings } \\
3110 \text { and } 3140 \text { was discharged to this leachfield. The } \\
\text { leachfield is located west of the R-MAD facility and is } \\
\text { composed of two distribution manifolds supplied by a } \\
\text { septic tank and diversion box. Fifteen } 100 \text {-ft long } \\
\text { distribution lines are connected to each distribution } \\
\text { manifold on } 8 \text {-ft centers. The distribution lines are } 6 \text {-in. } \\
\text { diameter open joint tiles installed in an 18-in. wide by } 12- \\
\text { to } 18 \text {-in. high gravel-filled trench and are approximately } \\
1 \mathrm{ft} \text { bgs. }\end{array}$ & $\begin{array}{l}\text { Engineering drawings } \\
\text { including 25-R-MAD-C1 } \\
\text { (REECo, 1983b), 3102-SW- } \\
7.1 \text { (BMEC, 1957a), and } \\
3102-S W-8.1 \text { (BMEC, 1957b) }\end{array}$ \\
\hline \multirow[t]{2}{*}{ Source location } & $\begin{array}{l}\text { Sources within Building 3110: Emergency showers, } \\
\text { equipment drains, floor drains, hoist well drain, laboratory } \\
\text { sinks, service sinks, sinks, toilets, and urinal. }\end{array}$ & \multirow[t]{2}{*}{ Engineering drawings } \\
\hline & $\begin{array}{l}\text { Sources within Building 3140: Floor drains, toilet, sink, } \\
\text { and service sink. }\end{array}$ & \\
\hline
\end{tabular}


Table A.2-2

CAS-Specific CAU 262 Conceptual Model

(Page 3 of 9)

\begin{tabular}{|c|c|c|}
\hline $\begin{array}{c}\text { Conceptual Model } \\
\text { Element }\end{array}$ & Assumptions & Source \\
\hline \multirow{3}{*}{$\begin{array}{l}\text { Contaminants of } \\
\text { Potential Concern }\end{array}$} & $\begin{array}{l}\text { Contaminants associated with sanitary effluent produced } \\
\text { by activities conducted within Buildings } 3110 \text { and } 3140 \text {. } \\
\text { Potential contamination was most likely produced by use } \\
\text { of floor drains within the source buildings. }\end{array}$ & \multirow{3}{*}{ Process knowledge } \\
\hline & $\begin{array}{l}\text { Building } 3110 \text { potentially hazardous COPCs identified } \\
\text { during preliminary assessment include: chemicals and } \\
\text { degreasers. } \\
\text { No specific radiological COPCs were identified. } \\
\text { Significant contribution of radiological contaminants } \\
\text { unlikely, but possible. }\end{array}$ & \\
\hline & $\begin{array}{l}\text { Building } 3140 \text { potentially hazardous COPCs identified } \\
\text { during preliminary assessment include material related to } \\
\text { paint shop activities (i.e., paints, solvents, and } \\
\text { lubricants). } \\
\text { No specific radiological COPCs were identified. } \\
\text { Significant contribution of radiological contaminants } \\
\text { unlikely, but possible. }\end{array}$ & \\
\hline \multicolumn{3}{|c|}{ CAS 25-05-12 } \\
\hline $\begin{array}{l}\text { System dynamics, } \\
\text { waste inventories, } \\
\text { release information }\end{array}$ & $\begin{array}{l}\text { Sanitary effluent generated within Buildings } 3111 \text { and } \\
3126 \text { was discharged to this leachfield. The leachfield is } \\
\text { located in the south-southeast area of the R-MAD facility } \\
\text { and is composed of two distribution manifolds supplied } \\
\text { by a septic tank. Three, } 80 \text {-ft long distribution lines are } \\
\text { connected to each distribution manifold on } 6 \text {-ft centers. } \\
\text { The distribution lines are } 4 \text {-in. diameter perforated VCP } \\
\text { installed in a } 5 \text {-ft wide by } 2 \text {-ft high gravel-filled trench and } \\
\text { are approximately } 1.7 \mathrm{ft} \text { bgs. }\end{array}$ & $\begin{array}{l}\text { Engineering drawings } \\
\text { including 25-R-MAD-C1 } \\
\text { (REECo, 1983b) and FMBF-2 } \\
\text { (FMBF, 1962) }\end{array}$ \\
\hline \multirow[t]{2}{*}{ Source location } & $\begin{array}{l}\text { Sources within Building } 3111 \text { : Deluge shower, drinking } \\
\text { fountain, floor sinks, sinks, service sink, toilets, and } \\
\text { urinal. }\end{array}$ & \multirow[t]{2}{*}{ Engineering drawings } \\
\hline & $\begin{array}{l}\text { Sources within Building 3126: Floor sinks, service sinks, } \\
\text { shower, sink, toilet, and urinal. }\end{array}$ & \\
\hline
\end{tabular}


Table A.2-2

CAS-Specific CAU 262 Conceptual Model

(Page 4 of 9)

\begin{tabular}{|c|c|c|}
\hline $\begin{array}{l}\text { Conceptual Model } \\
\text { Element }\end{array}$ & Assumptions & Source \\
\hline \multirow{3}{*}{$\begin{array}{l}\text { Contaminants of } \\
\text { Potential Concern }\end{array}$} & $\begin{array}{l}\text { Contaminants associated with sanitary effluent produced } \\
\text { by activities conducted within Buildings } 3111 \text { and } 3126 \text {. } \\
\text { Potential contamination was most likely produced by use } \\
\text { of floor drains/sinks within the source buildings. }\end{array}$ & \multirow{3}{*}{ Process knowledge } \\
\hline & $\begin{array}{l}\text { Building } 3111 \text { potentially hazardous COPCs identified } \\
\text { during preliminary assessment include: solvents and } \\
\text { degreasers. } \\
\text { No specific radiological COPCs were identified. } \\
\text { Significant contribution of radiological contaminants } \\
\text { unlikely, but possible. }\end{array}$ & \\
\hline & $\begin{array}{l}\text { Building } 3126 \text { potentially hazardous COPCs identified } \\
\text { during preliminary assessment include: Freon, dilute } \\
\text { acid, Tide washing soap, Turco cleaner, powdered citric } \\
\text { acid in water, alcohol, and trichloroethene. } \\
\text { Radiological COPCs include: Barium-137m, cesium-137, } \\
\text { plutonium, strontium-90, depleted uranium, uranium-234, } \\
\text { uranium, and yttrium-90. } \\
\text { Based on sources, it is unlikely that potentially hazardous } \\
\text { or radioactive COPCs were discharged to this leachfield. }\end{array}$ & \\
\hline \multicolumn{3}{|c|}{ CAS 25-51-01 } \\
\hline \multirow{2}{*}{$\begin{array}{l}\text { System dynamics, } \\
\text { waste inventories, } \\
\text { release information }\end{array}$} & $\begin{array}{l}\text { Sanitary effluent generated within Building } 3125 \text { was } \\
\text { discharged to this UDP. The UDP is located in the } \\
\text { southeast area of the R-MAD facility and is composed of } \\
\text { a gravel sump supplied by a discharge line. The UDP is } \\
\text { a 5-ft diameter by 5-ft deep gravel dry well. }\end{array}$ & $\begin{array}{l}\text { Engineering drawings } \\
\text { including 25-R-MAD-C1 } \\
\text { (REECo, 1983b) }\end{array}$ \\
\hline & $\begin{array}{l}\text { In addition to the UDP, this CAS includes a potential } \\
\text { leachfield identified only by surface expression (grading } \\
\text { with small berms to prevent run-on) and inconclusive } \\
\text { geophysics. }\end{array}$ & $\begin{array}{l}\text { Site visits, (IT 1999a), } \\
\text { Geophysics (IT, 1999b) }\end{array}$ \\
\hline \multirow{2}{*}{ Source location } & $\begin{array}{l}\text { Sources within Building } 3125 \text { : Floor drains. A service } \\
\text { sink may have been added to the system. }\end{array}$ & \multirow{2}{*}{ Engineering drawings } \\
\hline & $\begin{array}{l}\text { No sources have been identified for the potential } \\
\text { leachfield. }\end{array}$ & \\
\hline
\end{tabular}


Table A.2-2

CAS-Specific CAU 262 Conceptual Model

(Page 5 of 9 )

\begin{tabular}{|c|c|c|}
\hline $\begin{array}{l}\text { Conceptual Model } \\
\text { Element }\end{array}$ & Assumptions & Source \\
\hline \multirow[t]{2}{*}{$\begin{array}{l}\text { Contaminants of } \\
\text { Potential Concern }\end{array}$} & $\begin{array}{l}\text { Contribution of potentially hazardous effluent from } \\
\text { Building } 3125 \text { unlikely, but possible. Fluids associated } \\
\text { with maintenance of the Beetle vehicle may have been } \\
\text { discharged to the floor drains. } \\
\text { No specific radiological COPCs were identified. } \\
\text { Significant contribution of radiological contaminants } \\
\text { unlikely, but possible. Beetle vehicle was exposed to } \\
\text { radioactive source but is assumed not to have been } \\
\text { contaminated or to have been decontaminated prior to its } \\
\text { return to Building } 3125 \text {. }\end{array}$ & \multirow[t]{2}{*}{ Process knowledge } \\
\hline & $\begin{array}{l}\text { No specific potentially hazardous COPCs were identified } \\
\text { for the potential leachfield as no source has been } \\
\text { determined. Significant contribution of radiological } \\
\text { contaminants unlikely, but possible. } \\
\text { No specific radiological COPCs were identified. } \\
\text { Significant contribution of radiological contaminants } \\
\text { unlikely, but possible. }\end{array}$ & \\
\hline \multicolumn{3}{|c|}{ CAS Facility Association: Test Cell C } \\
\hline \multicolumn{3}{|c|}{ CAS 25-05-08 } \\
\hline $\begin{array}{l}\text { System dynamics, } \\
\text { waste inventories, } \\
\text { release information }\end{array}$ & $\begin{array}{l}\text { Radioactive effluent generated within Building } 3210 \text { was } \\
\text { discharged to this leachfield. The leachfield is located } \\
\text { south of the Test Cell C facility and is composed of two } \\
\text { distribution manifolds supplied by a diversion box. } \\
\text { Fifteen, } 60 \text {-ft long distribution lines are connected to each } \\
\text { distribution manifold on } 2 \text {-ft centers. The distribution } \\
\text { lines are } 6 \text {-in. diameter perforated VCP installed in an } 2 \text {-ft } \\
\text { wide by } 2 \text {-ft high gravel-filled trench and are } \\
\text { approximately } 5 \mathrm{ft} \text { bgs. }\end{array}$ & $\begin{array}{l}\text { Engineering drawings } \\
\text { including 25-TC-C-C1 } \\
\text { (REECo, 1984), 3222-PD- } \\
201 \text { (LASL, 1969a), and } \\
\text { 3222-PD-202 (LASL, 1969b) }\end{array}$ \\
\hline \multirow[b]{2}{*}{ Source location } & $\begin{array}{l}\text { The leachfield was apparently installed to receive } \\
\text { radioactive effluent generated by decontamination } \\
\text { activities at Test Cell C. }\end{array}$ & $\begin{array}{c}\text { Engineering drawing } \\
\text { 3222-PD-201 (LASL, 1969a) }\end{array}$ \\
\hline & $\begin{array}{l}\text { The collection system was modified to incorporate the } \\
\text { leachfield into the Nuclear Furnace exhaust scrubbing } \\
\text { system. Radioactive material produced by reactor tests } \\
\text { was removed from associated exhaust using a water and } \\
\text { filter system. The water was disposed of in this } \\
\text { leachfield. }\end{array}$ & $\begin{array}{c}\text { Engineering drawing } \\
\text { 25-TC-C-C1 (REECo, 1984), } \\
\text { LASL, } 1973\end{array}$ \\
\hline
\end{tabular}


Table A.2-2

CAS-Specific CAU 262 Conceptual Model

(Page 6 of 9 )

\begin{tabular}{|c|c|c|}
\hline $\begin{array}{l}\text { Conceptual Model } \\
\text { Element }\end{array}$ & Assumptions & Source \\
\hline & $\begin{array}{l}\text { Potentially hazardous and radioactive effluent associated } \\
\text { with Test Cell } \mathrm{C} \text { decontamination and Nuclear Furnace } \\
\text { exhaust scrubbing was discharged to this leachfield. }\end{array}$ & \\
\hline $\begin{array}{l}\text { Contaminants of } \\
\text { Potential Concern }\end{array}$ & $\begin{array}{l}\text { No potentially hazardous COPCs were identified during } \\
\text { preliminary assessment. Potentially hazardous COPCs } \\
\text { may be present based on process knowledge of Test } \\
\text { Cell C activities. } \\
\text { Radiological COPCs include: Antimony-125, cadmium- } \\
\text { 109, cesium-137, europium-155, potassium-40, radium- } \\
226 \text {, thorium-228, and thorium-232. }\end{array}$ & Process knowledge \\
\hline \multicolumn{3}{|c|}{ CAS 25-04-06 } \\
\hline \multirow{2}{*}{$\begin{array}{l}\text { System dynamics, } \\
\text { waste inventories, } \\
\text { release information }\end{array}$} & $\begin{array}{l}\text { Sanitary effluent generated within Building } 3228 \text { was } \\
\text { discharged to Leachfield A. The leachfield is located } \\
\text { south of the Test Cell C facility. The leachfield design is } \\
\text { poorly constrained, but a septic tank and distribution box } \\
\text { are present. Approximately six distribution lines within a } \\
270 \text { square ft area are shown on facility drawings. }\end{array}$ & \multirow{2}{*}{$\begin{array}{l}\text { Engineering drawing } \\
\text { 25-TC-C-C1 (REECo, 1984) }\end{array}$} \\
\hline & $\begin{array}{l}\text { Sanitary effluent generated within Building } 3220 \text { was } \\
\text { discharged to Leachfield B. The leachfield is located } \\
\text { south of the Test Cell C facility. The leachfield design is } \\
\text { poorly constrained, but a septic tank and distribution box } \\
\text { are present. Approximately } 6 \text { distribution lines within a } \\
2,115 \text { square ft area are shown on facility drawings. }\end{array}$ & \\
\hline \multirow[b]{2}{*}{ Source location } & $\begin{array}{l}\text { Sources within Building 3228: Water closets, urinals, } \\
\text { floor drains, clean-out drain, and wash fountain. }\end{array}$ & \multirow[b]{2}{*}{ Engineering drawings } \\
\hline & $\begin{array}{l}\text { Sources within Building } 3220 \text { : Equipment drains, floor } \\
\text { drain, sink with peg board, acid sink with fume hood, sink } \\
\text { drain. }\end{array}$ & \\
\hline
\end{tabular}


Table A.2-2

CAS-Specific CAU 262 Conceptual Model

(Page 7 of 9)

\begin{tabular}{|c|c|c|}
\hline $\begin{array}{l}\text { Conceptual Model } \\
\text { Element }\end{array}$ & Assumptions & Source \\
\hline \multirow{3}{*}{$\begin{array}{l}\text { Contaminants of } \\
\text { Potential Concern }\end{array}$} & $\begin{array}{l}\text { Contaminants associated with effluent produced by } \\
\text { activities conducted within Buildings } 3228 \text { and } 3220 \text {. } \\
\text { Potential contamination was most likely produced by use } \\
\text { of floor drains within the source buildings or the acid sink } \\
\text { in Building } 3220 \text {. }\end{array}$ & \multirow{3}{*}{ Process knowledge } \\
\hline & $\begin{array}{l}\text { Building } 3228 \text { potentially hazardous COPCs identified } \\
\text { during preliminary assessment include: } \\
\text { 1,2-dichlorethene, trichloroethene, 1,4-dichlorobenzene, } \\
\text { 4-methylphenol, tetrachloroethylene, oil. } \\
\text { Radiological COPCs include: Actinium-228, bismuth-212, } \\
\text { bismuth-214, cesium-137, europium-152, lead-212, } \\
\text { potassium-40, plutonium-238, plutonium-239, } \\
\text { radium-226, strontium-90, thallium-208, thorium-228, } \\
\text { thorium-232, and tritium. }\end{array}$ & \\
\hline & $\begin{array}{l}\text { No potentially hazardous COPCs for Building } 3220 \text { were } \\
\text { identified during preliminary assessment. Potentially } \\
\text { hazardous COPCs may be present based on process } \\
\text { knowledge. } \\
\text { Radiological COPCs include: Potassium-40, plutonium- } \\
238 \text {, plutonium-239, radium-226, thorium-228, thorium- } \\
232 \text {, and tritium. }\end{array}$ & \\
\hline \multicolumn{3}{|c|}{ CAS 25-04-07 } \\
\hline $\begin{array}{l}\text { System dynamics, } \\
\text { waste inventories, } \\
\text { release information }\end{array}$ & $\begin{array}{l}\text { Sanitary effluent generated within Building } 3210 \text { was } \\
\text { discharged to this leachfield. The leachfield is located } \\
\text { west of the Test Cell C facility. The leachfield design is } \\
\text { poorly constrained, but a septic tank and distribution box } \\
\text { are present. Approximately } 8 \text { distribution lines within an } \\
1,800 \text { square ft area are shown on facility drawings. }\end{array}$ & $\begin{array}{l}\text { Engineering drawings } \\
\text { including 25-TC-C-C1 } \\
\quad \text { (REECo, 1984) }\end{array}$ \\
\hline Source location & $\begin{array}{l}\text { Sources within Building 3210: Water closet, urinal, hand } \\
\text { sink, and floor drain. }\end{array}$ & Engineering drawings \\
\hline \multirow{2}{*}{$\begin{array}{l}\text { Contaminants of } \\
\text { Potential Concern }\end{array}$} & $\begin{array}{l}\text { Contaminants associated with sanitary effluent produced } \\
\text { by activities conducted within Building } 3210 \text {. Potential } \\
\text { contamination may have been produced by use of floor } \\
\text { drains within the source building. }\end{array}$ & \multirow[b]{2}{*}{ Process knowledge } \\
\hline & $\begin{array}{l}\text { Building } 3210 \text { potentially hazardous COPCs identified } \\
\text { during preliminary assessment include } \\
\text { tetrachloroethylene. } \\
\text { Radiological COPCs include europium-152 detected in a } \\
\text { background soil sample associated with leachfield } \\
\text { sampling. }\end{array}$ & \\
\hline
\end{tabular}


Table A.2-2

CAS-Specific CAU 262 Conceptual Model

(Page 8 of 9)

\begin{tabular}{|c|c|c|}
\hline $\begin{array}{l}\text { Conceptual Model } \\
\text { Element }\end{array}$ & Assumptions & Source \\
\hline \multicolumn{3}{|c|}{ CAS Facility Association: E-MAD } \\
\hline \multicolumn{3}{|c|}{ CAS 25-05-06 } \\
\hline $\begin{array}{l}\text { System dynamics, } \\
\text { waste inventories, } \\
\text { release information }\end{array}$ & $\begin{array}{l}\text { Radioactive effluent generated within Building } 3900 \text {, a } \\
\text { metallurgical trailer, and at the train decontamination } \\
\text { area and Building } 3900 \text { process effluent was discharged } \\
\text { to this leachfield. The leachfield is located south of the } \\
\text { E-MAD facility and is composed of two distribution } \\
\text { manifolds supplied by a diversion box. Twenty-four } \\
\text { approximately } 70 \text {-ft long distribution lines are connected } \\
\text { to each distribution manifold on } 8 \text {-ft centers. The } \\
\text { distribution lines are } 6 \text {-in. diameter open joint tiles } \\
\text { installed in an } 24 \text {-in. wide by } 18 \text {-in. high gravel-filled } \\
\text { trench and are approximately } 6 \mathrm{ft} \text { bgs. }\end{array}$ & $\begin{array}{l}\text { Engineering drawings } \\
\text { including 25-E-MAD-C1.1 } \\
\text { (REECo, 1983a) and } \\
\text { 1425-C-403 (VEC, 1963) }\end{array}$ \\
\hline \multirow{5}{*}{ Source location } & $\begin{array}{l}\text { Sources of radioactive effluent within Building 3900: All } \\
\text { shielded area floors including hot bay and hot cells. }\end{array}$ & \multirow{5}{*}{ Engineering drawings } \\
\hline & $\begin{array}{l}\text { Sources of process effluent within Building } 3900 \text { : } \\
\text { Operating gallery floor, maintenance and machine shop, } \\
\text { instrument shop, "cold" change room, boiler room, and } \\
\text { cold bay. }\end{array}$ & \\
\hline & $\begin{array}{l}\text { The heating, ventilation, and air conditioning stacks are } \\
\text { an additional radioactive effluent source. }\end{array}$ & \\
\hline & $\begin{array}{l}\text { The Metallurgical Trailer is an additional process and } \\
\text { radioactive effluent source. }\end{array}$ & \\
\hline & $\begin{array}{l}\text { The Train Decontamination Area is an additional process } \\
\text { and radioactive effluent source. }\end{array}$ & \\
\hline \multirow{3}{*}{$\begin{array}{l}\text { Contaminants of } \\
\text { Potential Concern }\end{array}$} & $\begin{array}{l}\text { Potentially hazardous and radioactive effluent associated } \\
\text { with assembly, maintenance, and disassembly of nuclear } \\
\text { reactors and rocket engines tested at the NRDS. } \\
\text { Additional work after termination of NRDS program may } \\
\text { also have contributed effluent to this leachfield. }\end{array}$ & \multirow{3}{*}{ Process knowledge } \\
\hline & $\begin{array}{l}\text { E-MAD facility potentially hazardous COPCs identified } \\
\text { during preliminary assessment include: Solvents and } \\
\text { degreasers, metallurgical process waste, and process } \\
\text { water stabilization additives (i.e., ethylene glycol). } \\
\text { Radiological COPCs include: Cesium-137, cobalt-60, } \\
\text { plutonium-239/240, strontium-90, uranium-235, } \\
\text { uranium-238. }\end{array}$ & \\
\hline & $\begin{array}{l}\text { COPCs associated with the metallurgical trailer are } \\
\text { unknown, but potentially hazardous and radioactive. }\end{array}$ & \\
\hline
\end{tabular}


Table A.2-2

CAS-Specific CAU 262 Conceptual Model

(Page 9 of 9 )

\begin{tabular}{|c|c|c|}
\hline $\begin{array}{l}\text { Conceptual Model } \\
\text { Element }\end{array}$ & Assumptions & Source \\
\hline \multicolumn{3}{|c|}{ CAS 25-02-06 } \\
\hline $\begin{array}{l}\text { System dynamics, } \\
\text { waste inventories, } \\
\text { release information }\end{array}$ & $\begin{array}{l}\text { Sanitary effluent generated within Buildings } 3900 \text { was } \\
\text { discharged to this leachfield. The leachfield is located } \\
\text { south of the E-MAD facility and is composed of two } \\
\text { distribution manifolds supplied by a septic tank and } \\
\text { diversion box. Fifteen, } 100 \text {-ft long distribution lines are } \\
\text { connected to each distribution manifold on } 8 \text {-ft centers. } \\
\text { The distribution lines are } 6 \text {-in. diameter open joint tiles } \\
\text { installed in an } 18 \text {-in. wide by } 12-\text { to } 18 \text {-in. high gravel- } \\
\text { filled trench and are approximately } 1 \mathrm{ft} \text { bgs. }\end{array}$ & $\begin{array}{l}\text { Engineering drawings } \\
\text { including 25-E-MAD-C1.1 } \\
\text { (REECo, 1983a) and } \\
\text { 1425-C-8 (VEC, 1965) }\end{array}$ \\
\hline \multirow[t]{2}{*}{ Source location } & $\begin{array}{l}\text { Sources within Building 3900: Restrooms, janitor rooms, } \\
\text { water closets, sinks, showers, drinking fountains, and } \\
\text { floor drains. }\end{array}$ & \multirow[t]{2}{*}{ Engineering drawings } \\
\hline & $\begin{array}{l}\text { Note that the hot change room restrooms drained to this } \\
\text { leachfield. }\end{array}$ & \\
\hline \multirow{2}{*}{$\begin{array}{l}\text { Contaminants of } \\
\text { Potential Concern }\end{array}$} & $\begin{array}{l}\text { No previous sampling results have been identified for this } \\
\text { leachfield system. }\end{array}$ & \multirow{2}{*}{ Process knowledge } \\
\hline & $\begin{array}{l}\text { Significant contribution of radiological or potentially } \\
\text { hazardous contaminants unlikely, but possible. }\end{array}$ & \\
\hline
\end{tabular}




\section{A.3.0 Potential Contaminants}

Additional information on the COPCs for CAU 262, including PALs and quality assurance/ quality control (QA/QC) requirements are provided in Section 3.0 of either the Leachfield Work Plan or the CAIP.

Previous sampling efforts and process knowledge identify the following potential contaminants:

- $\quad$ Radioactive and Chemical COPCs - These leachfields serviced buildings that were used for a variety of reactor testing and support activities. Activities within these buildings that likely contributed chemical effluents to one or more of the leachfields include film processing, decontamination/degreasing, radiochemistry, and reactor assembly and disassembly. In general, the contaminants that may be present are associated with organic solvents, hydrocarbons, paint, film processing agents, and activation and fission products.

- Previous sampling activities at the R-MAD posted leachfield identified significant concentrations of cesium-137 and cobalt-60. High beta/gamma activity was identified at the "pit/sump/drum."

- Previous sampling activities at the Test Cell $\mathrm{C}$ leachfields identified significant concentrations of cesium-137 at the posted leachfield; low concentrations of hydrocarbons and PCBs at CAS 25-04-07; a low concentration of gasoline-range TPH at Septic System B; and a high concentration of oil-range TPH and low concentrations of VOCs, SVOCs, and PCBs at Septic System A.

- Previous sampling activities associated with the E-MAD posted leachfield identified SVOCs, diesel-range TPH, RCRA metals, PCBs, gamma-emitting radionuclides, plutonium, uranium, and strontium at CAU 135. Previous sampling activities at the E-MAD posted leachfield identified gamma emitting radionuclides within the typical range of background.

Samples submitted for laboratory analysis will be analyzed for the following chemical COPCs to determine if potentially hazardous or hydrocarbon materials are present:

- VOCs

- SVOCs

- RCRA metals (arsenic, barium, cadmium, chromium, lead, mercury, selenium, and silver)

- TPH (diesel-range organics)

- PCBs (CASs 25-04-07 and 25-05-06) 
At least 25 percent (100 percent for CASs 25-05-03, 25-05-06, and 25-05-08) of samples submitted for laboratory analysis will be analyzed for the following COPCs to determine if radioactive materials are present:

- Gamma-emitting radionuclides

- Isotopic uranium

- Isotopic plutonium

- Strontium-90

All laboratory analyses will be conducted according to Table 3-1 of the Leachfield Work Plan or as specified in the CAIP. 


\section{A.4.0 Decisions and Inputs}

\section{A.4.1 Decisions}

Decisions to be resolved by the investigation include:

- Determine if COPCs are present at the sites.

- Determine if COPC concentrations exceed FSLs.

- Determine if COPC concentrations exceed PALs.

- Determine the nature and extent of contamination with enough certainty to develop and evaluate a range of potential corrective actions, including closure in place and clean closure.

\section{A.4.2 Inputs and Strategy}

Inputs to the decisions include those elements of information used to support the decisions in addressing the identified problem. A list of information inputs, existing data, identified data gaps, and brief strategies are discussed in Table A.4-1. 

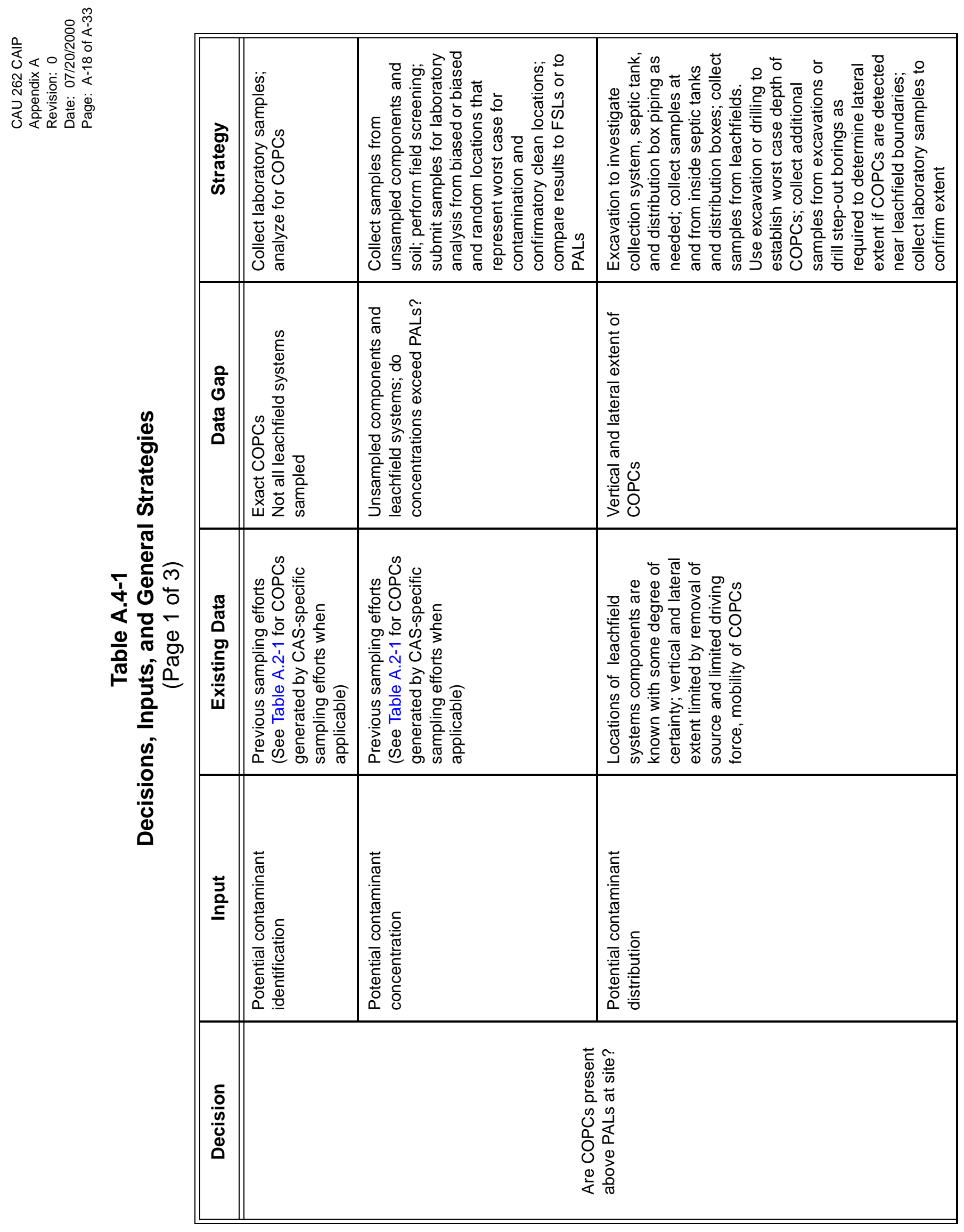

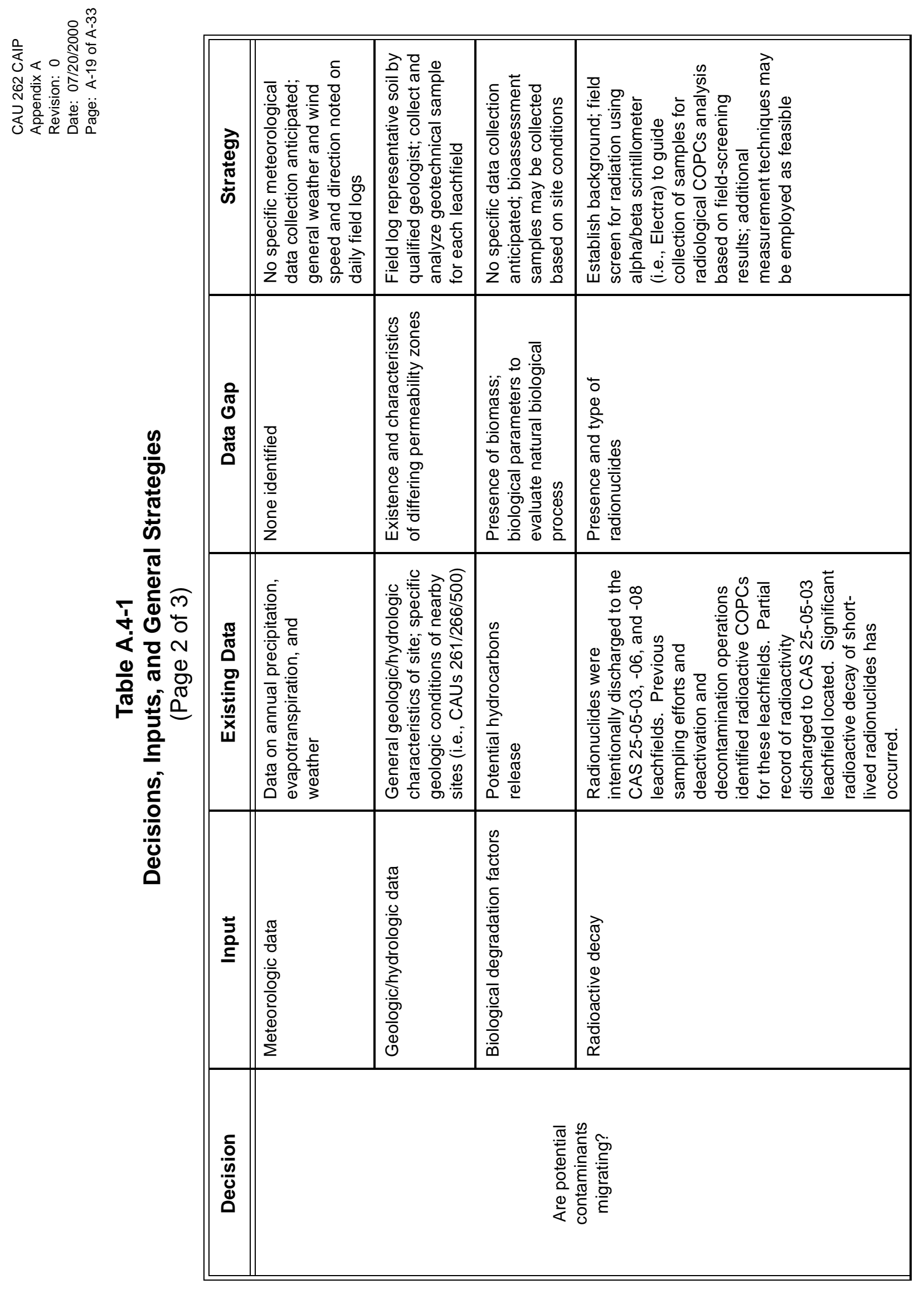

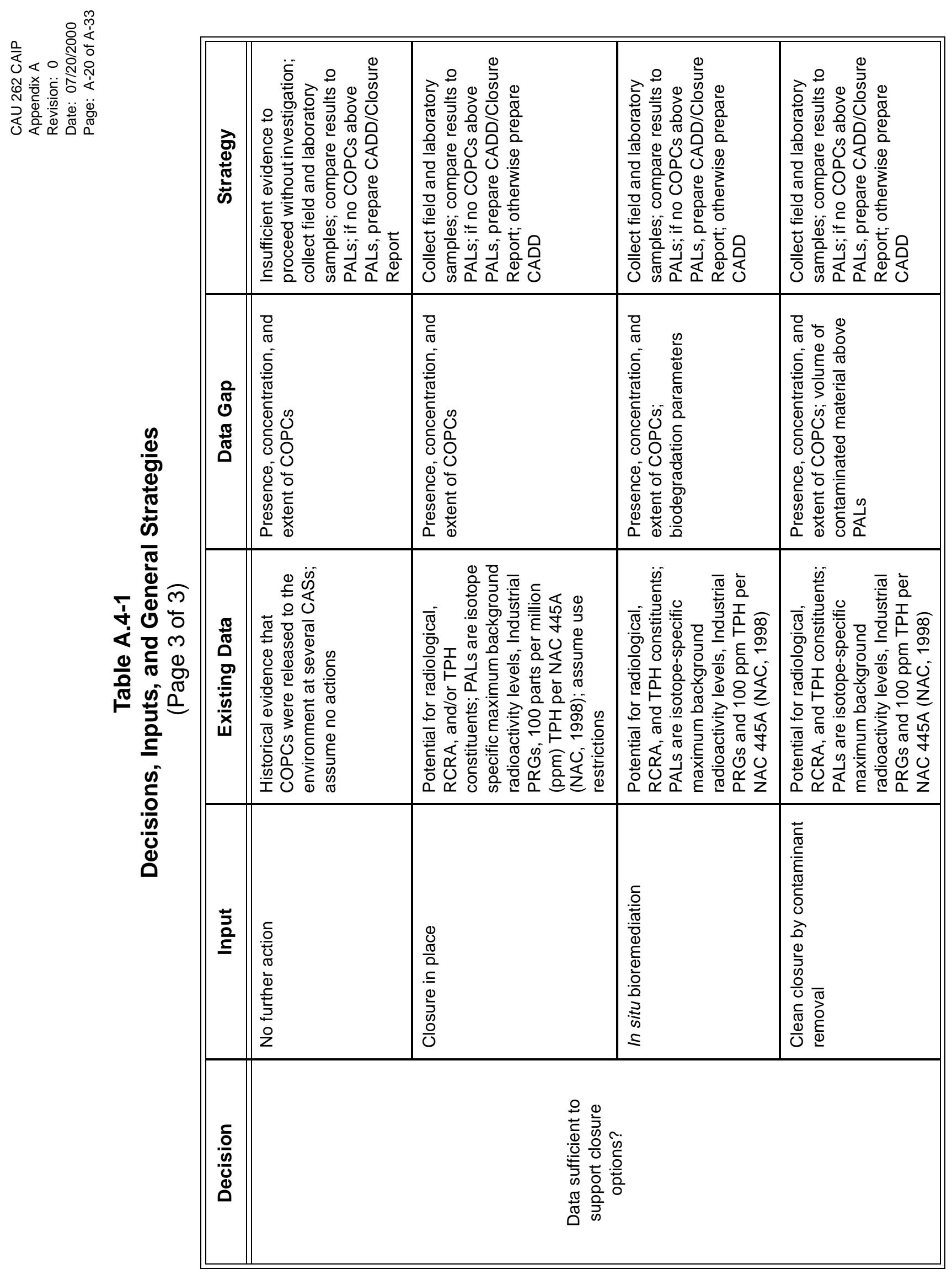


\section{A.5.0 Investigation Strategy}

The CAU 262 Leachfields will be investigated using the basic technical approach provided in the Leachfield Work Plan with site-specific modifications as required.

All soil and sediment/sludge samples will be field screened for VOCs and radioactivity. Samples will be analyzed according to Section A.3.0. Samples will be collected from septic tanks and distribution structures (if appropriate, accessible, and adequate material is present) and from soil underlying the leachrock/native soil interface. Contents of previously sampled septic tanks will not be collected if previous sample results are adequate for waste management requirements. Contrary to the leachfield work plan, integrity samples will be collected from proximal and distal end soil at the base of septic tanks and from the distal end soil at the base of distribution structures.

The CAS-specific investigation strategy is dependent on the COPCs and the leachfield design. Complex leachfields with a high likelihood of radiological contamination will be investigated using an initial phase of in situ radiation measurement followed by biased and random sample collection using drilling. Complex leachfields that are not expected to contain significant radiological contamination will be investigated by biased and random sampling using excavation. Simple leachfields will be investigated by biased sampling using excavation. Drilling may be used to augment excavation throughout the investigation if required to determine the maximum vertical extent of potential contamination. This sampling strategy will ensure that contamination in the soil has been adequately located, identified, and quantified.

\section{A.5.1 Sampling at Radiologically Posted Leachfields}

Based on preliminary assessment, the leachfields addressed by CASs 25-05-03, 25-05-06, and 25-05-08 may contain significant radiological contamination. The radioactivity of soil to be sampled may be determined using in situ radiation measurements if feasible. Sample collection from these leachfields is contingent upon the radioactivity of the soil to be sampled. Samples that are too radioactive to practically handle, transport, or submit for analysis may not be collected. 
The total number of samples submitted for off-site quantitative analysis may be significantly reduced based on these considerations.

Drilling will be the primary sampling method. Biased and random sampling will be conducted during the field investigation to assess the extent of COPCs and determine if COPC concentrations exceed PALs for the site.

Boreholes will be located based on system dynamics and statistical analysis. Biased boreholes will be drilled at the initial discharge points in the two proximal distribution lines, the area between the distribution manifold ends, the four corners, and center of each leachfield. Additional boreholes will be located at the center of each half of the leachfields. Due to the extreme slope of the CAS 25-05-06 leachfield, four of the biased borehole locations will be at different locations. For this leachfield, boreholes will be drilled at the initial discharge points in the two distribution lines approximately at the proximal end of the distal one-third of the leachfield and the center of the distal two-thirds of each half of the leachfield. Additional locations will be selected randomly within the area of the leachfield to ensure adequate sampling locations have been considered. The number of random locations are addressed in Section A.7.0.

\section{A.5.2 Sampling at R-MAD and E-MAD Complex Sanitary Leachfields}

Excavation will be the primary sampling method for leachfields in CASs 25-05-05 and 25-05-06. Biased and random sampling will be conducted during the field investigation to assess the extent of COPCs and determine if COPC concentrations exceed PALs for the site. Drilling will be conducted if excavation sampling fails to determine the maximum vertical extent of potential contamination.

Excavations will be located based on system dynamics and statistical analysis. Biased excavations will be located at the initial discharge points in the two proximal distribution lines, the area between the distribution manifold ends, the four corners and center of each leachfield. Additional excavations will be located at the center of each half of the leachfields. Additional locations will be selected randomly within the area of the leachfield to ensure adequate sampling locations have been considered. The number of random locations are addressed in Section A.7.0. 


\section{A.5.3 Sampling at Remaining Leachfields and UDP}

Samples will be collected from the leachfields addressed by CASs 25-04-06, 25-04-07, 25-05-12, and 25-51-01 according to the Leachfield Work Plan using excavation. A biased and random sampling approach, as described in Section A.5.2, may be required if more distribution lines than expected are located (see Section A.6.0). Drilling will be conducted if excavation sampling fails to determine the maximum vertical extent of potential contamination.

A leachfield and UDP are addressed by CAS 25-51-01. It is unlikely that the leachfield addressed by CAS 25-51-01 exists. This potential leachfield will be investigated by excavating a single trench across a graded area with small berms and perpendicular to the lineations identified by an inconclusive geophysical survey. If distribution lines are located, samples will be collected using continued excavation or drilling depending on field-screening results. The UDP will be investigated by drilling a borehole at the center of the feature and collecting soil samples beginning at the native soil/leachrock interface. Three stepout borings will be drilled in a roughly triangular pattern approximately $15 \mathrm{ft}$ from the UDP if FSLs are exceeded.

\section{A.5.4 Limited Collection System Pipe Inspections}

The collection systems will be inspected using one of four CAS-specific strategies:

- Portions of the posted leachfield collection systems will be inspected using a video survey and in situ radiation measurements as described in Section 4.1.1.4 of the Leachfield Work Plan. The in situ radiation measurements are designed to determine if the pipes meet freerelease criteria.

- A portion of the CAS 25-04-07 collection system will be inspected using a video survey. Access to most of the collection system piping is limited by extensive concrete cover and no attempt will be made to collect sediment samples from the pipes. Contamination associated with the sampled leachfield system components will be attributed to the sediment within the collection system if significant sediment is present in the piping.

- The CAS 25-04-06 collection systems will be excavated at a point between the source buildings and the leachfields. System A will be inspected at the nominal midpoint of the collection system piping and System B will be inspected adjacent to (outside) the Test Cell $\mathrm{C}$ security fence. If sediment is present at the inspection locations, it will be sampled and analyzed for the chemical and radiological parameters provided in Section A.3.0. 
- The remaining collection systems will be inspected via manholes. If manholes cannot be located, the investigation strategy will be consistent with that used for CAS 25-04-06. If sediment is present at the inspection locations, it will be sampled and analyzed for the chemical and radiological parameters provided in Section A.3.0.

\section{A.5.5 Additional Sampling}

Bioassessment samples may be collected according to the Leachfield Work Plan at the Site Supervisor's discretion. Need for bioassessment samples will be based on the nature of contamination established during the field investigation (i.e., extensive VOC contamination).

At least one geotechnical sample will be collected from soil underlying the leachfields according to Section 3.2.1 of the Leachfield Work Plan. Additional samples may be collected at the discretion of the Site Supervisor. Geotechnical samples will be analyzed using the methods in Table 3-2 of the Leachfield Work Plan to measure the following parameters:

- Initial moisture content

- Dry bulk density

- Calculated porosity

- Moisture retention characteristics

- Particle size distribution

- Saturated and unsaturated hydraulic conductivity 


\section{A.6.0 Decision Rules}

The following decision rules will be used to guide the investigation and subsequent data evaluation for CAU 262:

- If, in the course of the investigation, either of the following occur, then the investigation will be halted and rescoped as necessary:

- The conceptual model fails to such a degree that rescoping is required.

- Sufficient data are collected to support evaluation of corrective actions.

- If field screening indicates no COPCs above FSLs, then a sample at the next prescribed subsurface location will be field screened. If no COPCs are indicated, a confirmatory laboratory sample will be submitted.

- If field screening indicates the presence of COPCs above FSLs, then the investigation will continue to determine extent of COPCs a sample with field-screening results below FSLs is obtained for laboratory submittal. Sample depth may be limited by maximum practicable excavation or drilling depth. A sample will also be submitted for laboratory analysis from the subsurface interval that represents the worst-case, field-screening result and at the discretion of the Site Supervisor. Some worst-case samples may not be submitted due to transportation or laboratory limitations. Additional samples may be required for waste management purposes.

- If laboratory results indicate the presence of contaminants of concern above PALs, then a CADD will be prepared. Potential corrective actions may be CAS-specific.

- If no COPCs are identified above PALs, then a CADD/Closure Report will be prepared according to the outline agreed upon by NDEP and DOE/NV. This type of CADD incorporates the elements of the regular CADD and the corrective action plan and serves as the closure report for the site. Recommendations of no further action may be CAS-specific.

Table A.6-1 provides additional decision points and rules. 

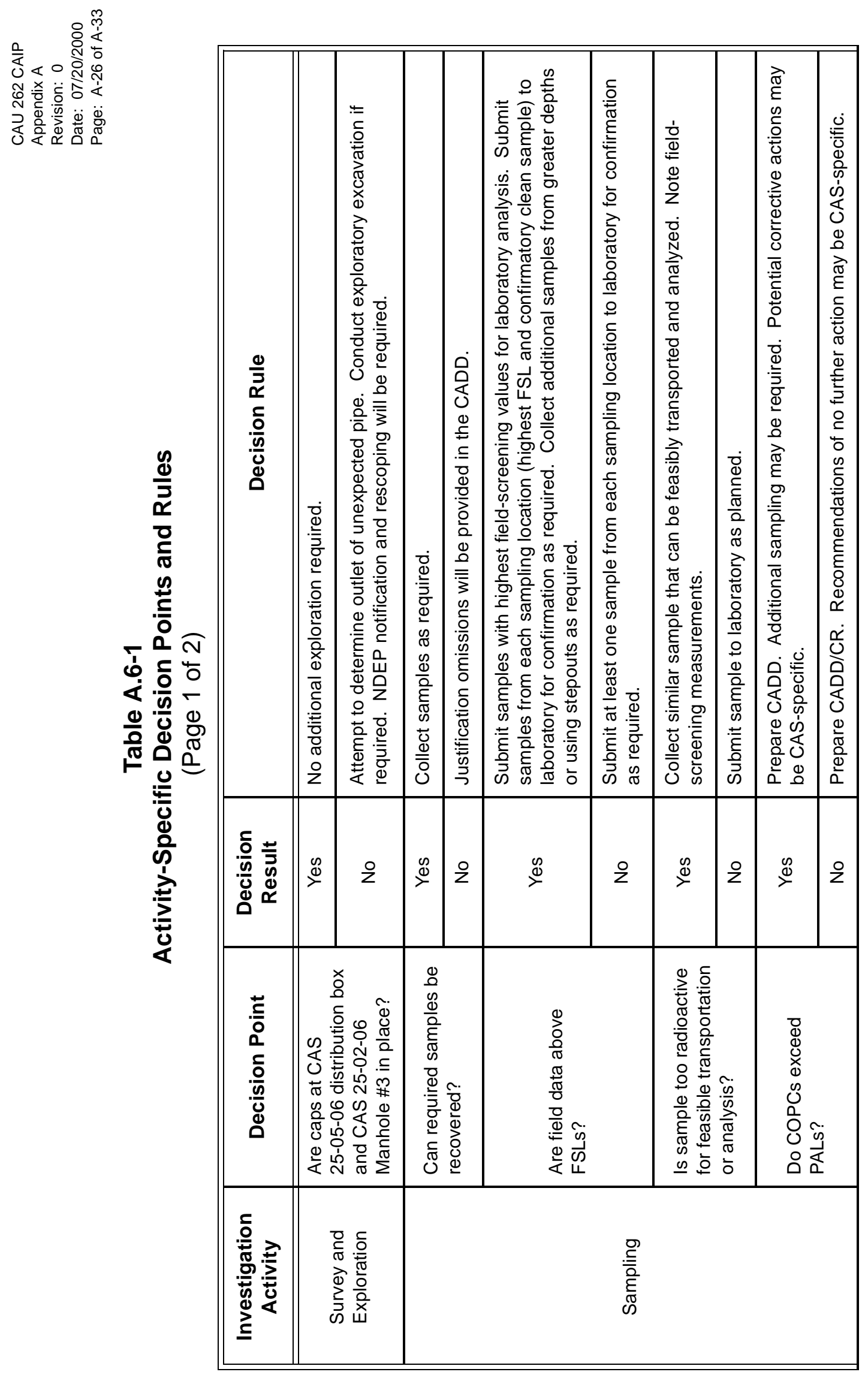

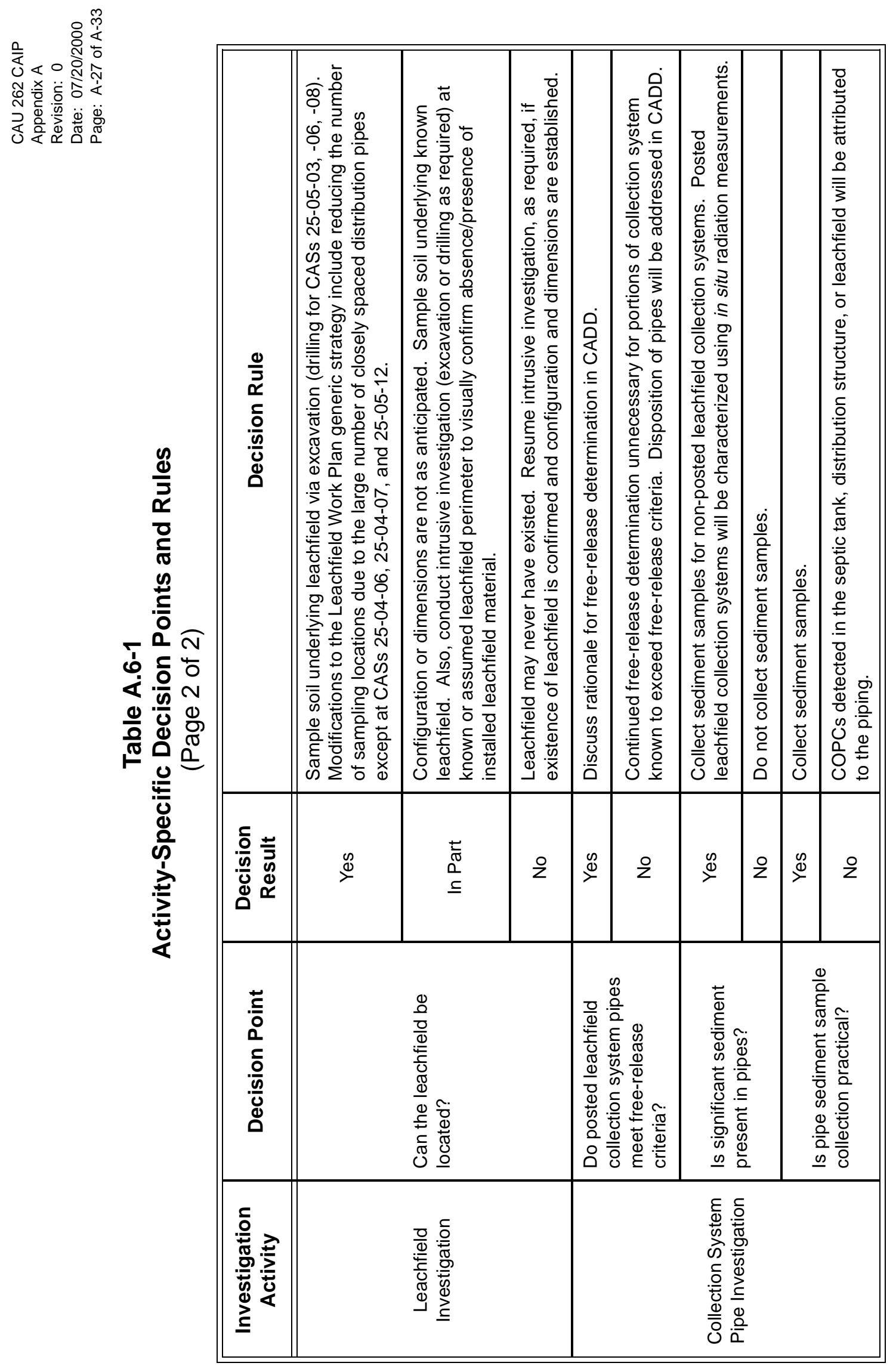


\section{A.7.0 Decision Error}

As described in Section A.5.0, biased or a combination of random and biased sampling strategy will be employed for CAU 262 leachfields. Biased sampling is appropriate because the system component locations are known, will be located through exploratory surveys, or can be reasonably assumed. Random sampling will also be conducted for leachfields with large numbers of distribution lines to reduce redundant sampling results while maximizing confidence that the leachfields have been adequately investigated.

Table A.6-1 describes actions if specific component locations cannot be identified.

\section{A.7.1 Biased Sampling Strategies}

The biased sampling strategies either require samples associated with all distribution lines or target the worst-case contamination by concentrating leachfield system sampling at points with highest potential for contamination. Biased sampling ensures that the extent of the contamination has been adequately located and identified. At least one sample with field-screening results below FSLs will be obtained from the predetermined sampling locations to define the lower limit of the impact (if any) on soils produced by effluent disposal. Field-screening results will be confirmed by off-site laboratory analysis of these samples.

\section{A.7.2 Random Sampling Strategy}

Systematic random sampling will be employed for investigation of the several leachfields addressed by CAU 262 (see Section A.5.0). This approach will ensure coverage of the potentially contaminated areas at leachfields where soil samples are not directly associated with each distribution pipe. The number of samples required to characterize the sites to a predetermined level of confidence will be calculated using Equation 8 from Chapter 9 of SW-846 (EPA, 1996), with a confidence level and acceptable sampling error agreed to by the DOE/NV and the NDEP. 
Equation 8 from Chapter 9 of SW-846 gives the number of samples required to determine the mean value of a given parameter to within a specified percent error, $e_{r}$, with a confidence limit of 90 percent, using an analytical method with a specified coefficient of variation (CV), as:

$\mathrm{n}=\left(\mathrm{t}_{0.90, \mathrm{n}-1} \frac{\mathrm{CV}}{\mathrm{e}_{\mathrm{r}}}\right)^{2}$

where " $\mathrm{t}$ " is the one-tailed 90 percent Student's " $t$ " value for the appropriate number of degrees of freedom (n-1).

The $\mathrm{CV}$ in the above equation refers to the variability of the specific parameter in the medium being sampled. Its value cannot be determined until sufficient samples from the site have been analyzed. However, in the absence of data regarding the soil variability of the COPCs at CAU 262, some assumptions must be made:

- The variability of the analytical method may be used as a first approximation of the variability of the contaminant distribution in the soil. This is probably a reasonable assumption for chemical contaminants, which are likely to have been deposited from a solution, thus leading to a somewhat uniform distribution.

- Table A.7-1 shows the average CVs for several chemical methods, as determined from the individual procedures in SW-846. Pesticides and PCBs are included, although neither of these are COPCs at CAU262.

- For radiological contaminants, higher average CVs should be considered. Radiological contaminants are typically particulate in nature and are thus likely to be less uniformly distributed in the medium under investigation, leading to high variability.

For CAU 262, a CV of 50 percent will be assumed. This figure represents a compromise between the very high CVs of the pesticides and the extremely low CVs of the VOCs and SVOCs. It is an acceptable starting point for the purposes of Equation 8. 
Table A.7-1

Average Coefficients of Variation

\begin{tabular}{|c|c|c|}
\hline SW-846 Method & Parameter Measured & $\%$ CV \\
\hline \hline $6010 \mathrm{~B}$ & Metals & 21.3 \\
\hline $7470 \mathrm{~A} / 7471 \mathrm{~A}$ & Mercury & 69.5 \\
\hline $8260 \mathrm{~B}$ & VOCs & 7.5 \\
\hline $8270 \mathrm{C}$ & SVOCs & 9.1 \\
\hline $8081 \mathrm{~A}$ & Pesticides & 70.1 \\
\hline 8082 & PCBs & 29.7 \\
\hline
\end{tabular}

A relative error of 10 to 20 percent from the true mean at a confidence limit of 90 percent is considered acceptable for planned removal and remedial response studies (EPA, 1989). A relative error of 15 percent will be specified for this site. Substituting the appropriate values for " $t$ " (Taylor, 1990), CV (50 percent) and $\mathrm{e}_{\mathrm{r}}$ (15 percent) into this equation and iterating the equation several times gives $\mathrm{n}=20$. Twenty random sample locations will be sampled in addition to nine biased sample locations. 


\section{A.8.0 References}

BMEC, see Burns \& McDonnell Engineering Company.

Burns \& McDonnell Engineering Company. 1957a. Engineering Drawing

Number 3102-SW-7.1, "MAD Building Septic Tank Details.” Kansas City, MO.

Burns \& McDonnell Engineering Company. 1957b. Engineering Drawing

Number 3102-SW-8.1, "MAD Building Sanitary Disposal Field Details.” Kansas City, MO.

Burns \& McDonnell Engineering Company. 1959. Engineering Drawing Number 3102-SW-6.1,

"MAD Building Process Disposal Field Details." Kansas City, MO.

DOE/NV, see U.S. Department of Energy, Nevada Operations Office.

EPA, see U.S. Environmental Protection Agency.

FMBF, see Flatow, Moore, Bryan and Fairburn.

Flatow, Moore, Bryan, and Fairburn. 1962. Engineering Drawing Number FMBF-2, "Hot Storage and Decontamination." Albuquerque, NM.

IT, see IT Corporation.

IT Corporation. 1999a. Field Activity Daily Logs for CAU 135 Corrective Action Investigation Las Vegas, NV.

IT Corporation. 1999b. Fourth Quarter 1999 Surface Geophysical Survey Report, Potential Corrective Action Sites, Area 25 RMAD Vicinity at the Nevada Test Site, Nye County, Nevada. Prepared by Science Applications International Corporation. Middletown, PA.

LASL, see Los Alamos Scientific Laboratory.

Los Alamos Scientific Laboratory. 1969a. Engineering Drawing Number 3222-PD-201, "Test Cell 'C' Radioactive Waste Disposal Field Plan.” Los Alamos, NM.

Los Alamos Scientific Laboratory. 1969b. Engineering Drawing Number 3222-PD-202, "Test Cell 'C' Radioactive Waste Disposal Field Profile and Details." Los Alamos, NM.

Los Alamos Scientific Laboratory. 1973. Nuclear Furnace-1 Test Report, LA-5189-MS. Los Alamos, NM. 
NAC, see Nevada Administrative Code.

Nevada Administrative Code. 1998. NAC 445A, "Water Controls." Carson City, NV: Nevada Division of Environmental Protection.

REECo, see Reynolds Electrical \& Engineering Co., Inc.

Reynolds Electrical \& Engineering Co., Inc. 1983a. Engineering Drawing Number 25-E-MAD-C1.1, "Existing Water \& Sewer Layout, E-MAD Facility." Las Vegas, NV.

Reynolds Electrical \& Engineering Co. Inc. 1983b. Engineering Drawing Number 25-R-MAD-C1, "Existing Water \& Sewer Layout, R-MAD Facility." Las Vegas, NV.

Reynolds Electrical \& Engineering Co., Inc. 1984. Engineering Drawing Number 25-TC-C-C1, "Existing Water \& Sewer Layout, Test Cell 'C'." Las Vegas, NV.

Taylor, J.K. 1990. Statistical Techniques for Data Analysis. Chelsea, MI:

Lewis Publishers, Inc.

U.S. Department of Energy, Nevada Operations Office. 1996. Industrial Sites Quality Assurance Project Plan, Nevada Test Site, Nevada, Rev. 1, DOE/NV--372. Las Vegas, NV.

U.S. Department of Energy, Nevada Operations Office. 1998a. Nevada Test Site Resource Management Plan, DOE/NV--518. Las Vegas, NV.

U.S. Department of Energy, Nevada Operations Office. 1998b. Work Plan for Leachfield Corrective Action Units: Nevada Test Site and Tonopah Test Range, Nevada, Rev.1, DOE/NV--514. Las Vegas, NV.

U.S. Department of Energy, Nevada Operations Office. 1999. Corrective Action Decision Document for Corrective Action Unit 261: Area 25 Test Cell A Leachfield System, Nevada Test Site, Nevada, DOE/NV--583. Las Vegas, NV.

U.S. Department of Energy, Nevada Operations Office. 2000a. Corrective Action Decision Document/Closure Report for Corrective Action Unit 266: Area 25 Building 3124 Leachfield, Nevada Test Site, Nevada, DOE/NV--577. Las Vegas, NV.

U.S. Department of Energy, Nevada Operations Office. 2000b. Corrective Action Decision Document/Closure Report for Corrective Action Unit 500: Test Cell A Septic System, Nevada Test Site, Nevada, DOE/NV--575. Las Vegas, NV. 
U.S. Environmental Protection Agency. 1989. Soil Sampling Quality Assurance User's Guide, Second Edition, EPA/600/8-89/046. Washington, DC.

U.S. Environmental Protection Agency. 1996. Test Methods for Evaluating Solid Waste, Physical/Chemical Methods, SW-846, Third Edition, CD ROM, PB97-501928GEI (CD ROM includes revisions to 1986, 1992, and 1994). Washington, DC.

VEC, see Vitro Engineering Company.

Vitro Engineering Company. 1963. As-Built Engineering Drawing Number 1425-C-403 titled, "N.R.D.S. E-MAD Facility - Phase II, Civil Works, R.W.D. Profile - Diversion Box and Details," 8 November. Mercury, NV: Archives and Records Center.

Vitro Engineering Company. 1965. Engineering Drawing Number 1425-C-8, "N.R.D.S. E-MAD Facility Sanitary Septic Tank Plans, Section and Details.” New York, NY. 
CLOSURE RE PORT - CAU 262

Section: Appendix A

Revision : 1

Date: July 2003

THIS PAGE INTENTIONALLY LEFT BLANK 


\section{APPENDIX B}

\section{SAMPLE ANALYTICAL RESULTS}


CLOSURE RE PORT - CAU 262

Section: Appendix B

Revision : 1

Date: July 2003

THIS PAGE INTENTIONALLY LEFT BLANK 
Ted Redding

Bechtel Nevada

P.O. Box 98521 , M/S NTS273

Las Vegas, NV 89193-8521

TEL: 702-295-7220

RE Project: CAU 262

Order No.: L0210354

Dear Ted Redding:

NEL Laboratories, Las Vegas received 3 samples on 10/22/02 for the analyses presented in the following report.

There were no problems with the analyses and all data for associated QC met EPA or laboratory specifications unless noted in the Case Narrative.

If you have any questions regarding these tests results, please feel free to call.

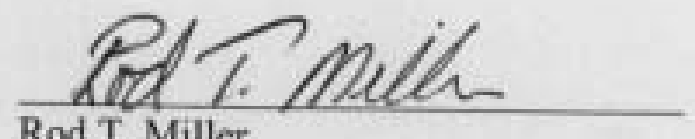

Rod T, Miller

Laboratory Director

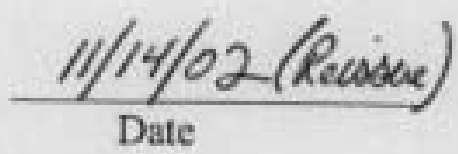

Certifications:

$\begin{array}{ll}\text { Arizona } & \text { AZ0518 } \\ \text { California } & 2002 \\ \text { Idaho } & \text { Certified } \\ \text { Montana } & \text { Certified } \\ \text { Nevada } & \text { NV052 } \\ \text { New Mexico } & \text { Certified }\end{array}$


CLOSURE RE PORT - CAU 262

Section: Appendix B

Revision : 1

Date: July 2003

\section{THIS PAGE INTENTIONALLY LEFT BLANK}


NEL Laboratories, Las Vegas

CLIENT: Bechtel Nevada

Project: CAU 262

Lab Order: L0210354
Date: $14-\mathrm{Nov}-02$

\section{CASE NARRATIVE}

Attached are the analytical results for samples in support of the above referenced project.

The samples submitted for this project were not sampled by NEL. Should you have any questions or comments, please feel free to contact our Client Services Department.

Analytical Comments:

TPH Analysis:

F1: Hydrocarbon pattern atypical of gasoline.

F3: Hydrocarbon pattern atypical of diesel.

S6: Surrogate recovery was below laboratory and method limits. Reextraction and reanalysis confirm low recovery caused by matrix effects.

At the request of the client, samples 250505-waste-1 and 250512-waste-1 were reextracted and reanalyzed for TPH analysis in order to achieve a lower reporting limit. 
CLOSURE RE PORT - CAU 262

Section: Appendix B

Revision : 1

Date: July 2003

\section{THIS PAGE INTENTIONALLY LEFT BLANK}




\section{Bechtel Nevada}

\section{DATA VALIDATION COVER SHEET}

\section{Section I}

MEF Number:

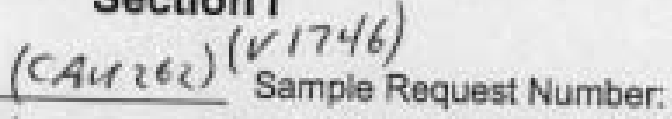

Contract Laboratory: NEL C.porefories Organization: BN ER

Validation Procedure/Instruction, including revision number: $01-2151.30\}$ The. 1

Analysis Requested (check all that apply):

1 Volatile Organics

Semi Volatile Organics

(D) TH ORO)

Inorganics

$\square$ Organochlorine Pesticides/Polychlorinated Biphenals (PCBs)

$\square$ Radiochemistry

1. Chain-of-Custody Form

\section{Section II}

2. $\square$ Case Narrative

3. Sample Results Forms

4. $\square$ Field Forms

5. Uuality Control Forms

Identify any samples that are missing:

Comments/Problems: (include information about requests for further information submitted to the contract

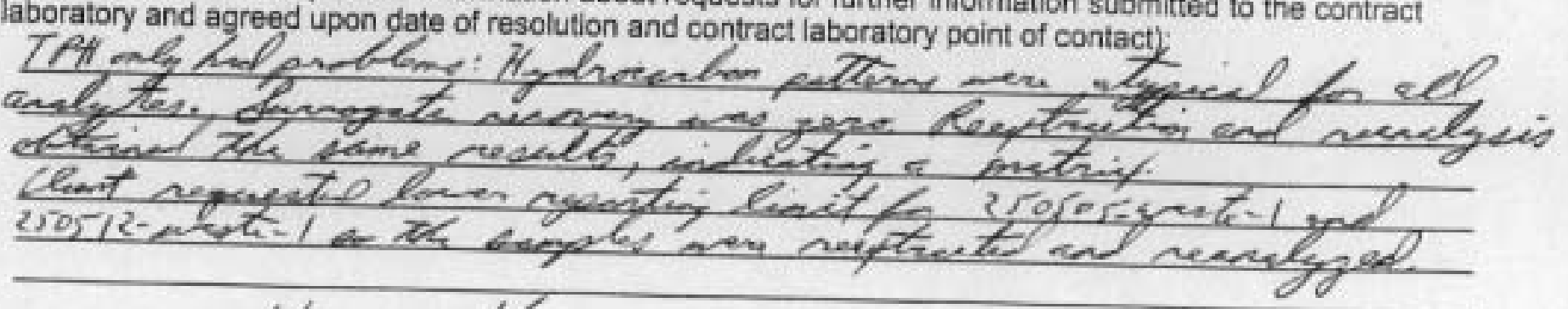

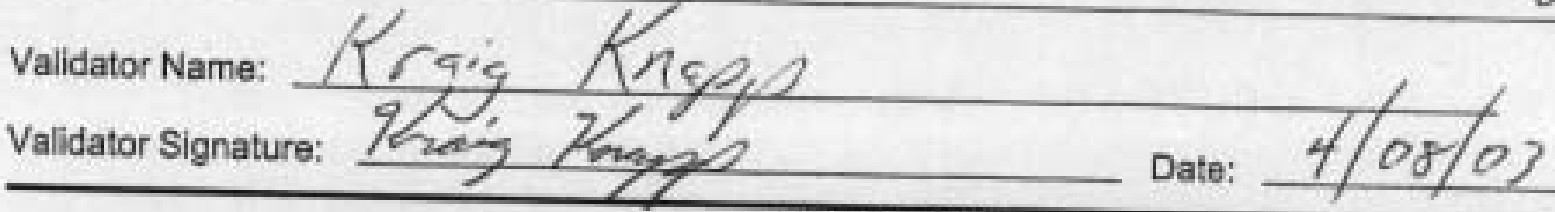




\section{DATA VALIDATION CHECKLIST}

Analyses Reviewed:

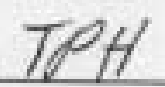

Date: $4 / 8 / 03$

\section{DATA REVIEW}

1. Requested analyses were performed on all samples.

2. Samples were extracted, prepared, and analyzed within holding times.

3. Cooler temperature was recorded upon receipt.

4. Proper preservation / $\mathrm{pH}$ was used for each matrix and analysis.

5. The laboratory sample identification corresponds to the client sample identification.

6. Background checks were performed at the proper frequency and were acceptable.

7. efficiency checks were performed at the proper frequency and were acceptable.

8. Method blanks were analyzed and were acceptable.

9. All MDAs were less than the RDLs.

10. LCSs were analyzed at the proper frequency and recoveries were acceptable.

11. MS were analyzed at the proper frequency and recoveries were acceptable.

12. Lab duplicates were analyzed the proper frequency and RPDs were acceptable.

13. QC batches correspond clearly with analytical batches.

14. Sample activity/concentration units are reported accurately.

15. Dilutions were properly noted and calculated.

16. Sample detection limits were properly adjusted for dilutions.

17. Detection limits meet project requirements.

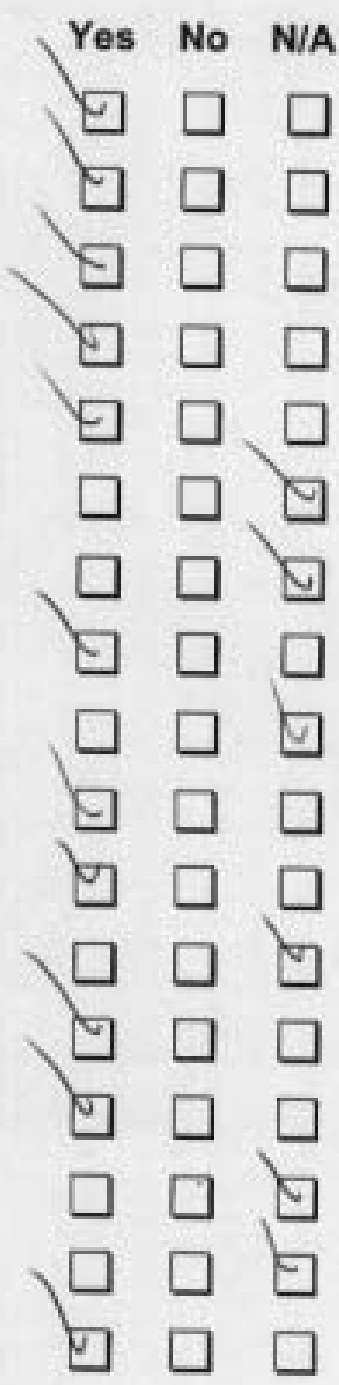

\section{QUALIFIERS}

\section{QC Result}

Preparation Blank:

Qualifier

Lab Control Sample:

Matrix Spike:

Duplicate Sample:

Validator Name

Signature:

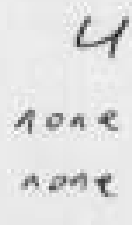

none
Associated Sample Results

250505 -wotel, 250512-warte-

(1)

(1)

$*$

'

") 
Bechtel Nevada

DATA VALIDATION CHECKLIST

Analyses Reviewed: DATA REVIEW

1. Requested analyses were performed on all samples.

2. Samples were extracted, prepared, and analyzed within holding times.

3. Cooler temperature was recorded upon receipt.

4. Proper preservation / pH was used for each matrix and analysis.

5. The laboratory sample identification corresponds to the client sample identification.

6. Background checks were performed at the proper frequency and were acceptable.

7. efficiency checks were performed at the proper frequency and were acceptable.

8. Method blanks were analyzed and were acceptable.

9. All MOAs were less than the RDLs.

10. LOSs were analyzed at the proper frequency and recoveries were acceptable.

11. MS were analyzed at the proper frequency and recoveries were acceptable.

12. Lab duplicates were analyzed the proper frequency and RDs were acceptable.

13. QC batches correspond clearly with analytical batches.

14. Sample activity/concentration units are reported accurately.

15. Dilutions were properly noted and calculated.

16. Sample detection limits were properly adjusted for dilutions.

17. Detection limits meet project requirements.

QUALIFIERS

QC Result

Preparation Blank:

Lab Control Sample:

Matrix Spike:

Duplicate Sample:
Date:

$4 / 8 / 03$

Yes oㅡ

Yes No NA 


\section{Bechtel Nevada \\ DATA CONFIDENCE STATEMENT}

MEF Number: CAU26L SDE $\sim 1746$ Analyses: VOC, TPH

$\triangle$ Field and QAVC sample data have been generated in accordance with method requirements andwithing quality control. Requirements of the SOW have been met. Comments: Voy axalyi

QA/OC problems were encountered during analysis of the samples. Usability is not
affected, data are acceptable.

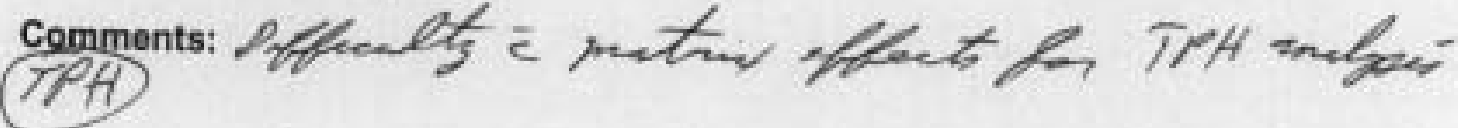

Significant QAVQC problems were encountered during analysis of the samples.

Data for the following samples is rejected:

Summary:

Validator Name: Kraig Ralidator Signature: Kasis Res

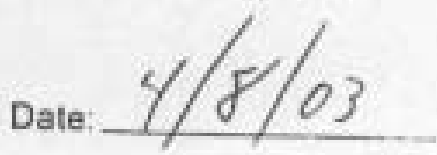




\section{TIER I REVIEW}

\section{GENERAL INFORMATION}

1. Project Name and/or Sample Delivery Group (SDG): $V / 746$

2. Date Samples taken: $10 / 21 / 02$

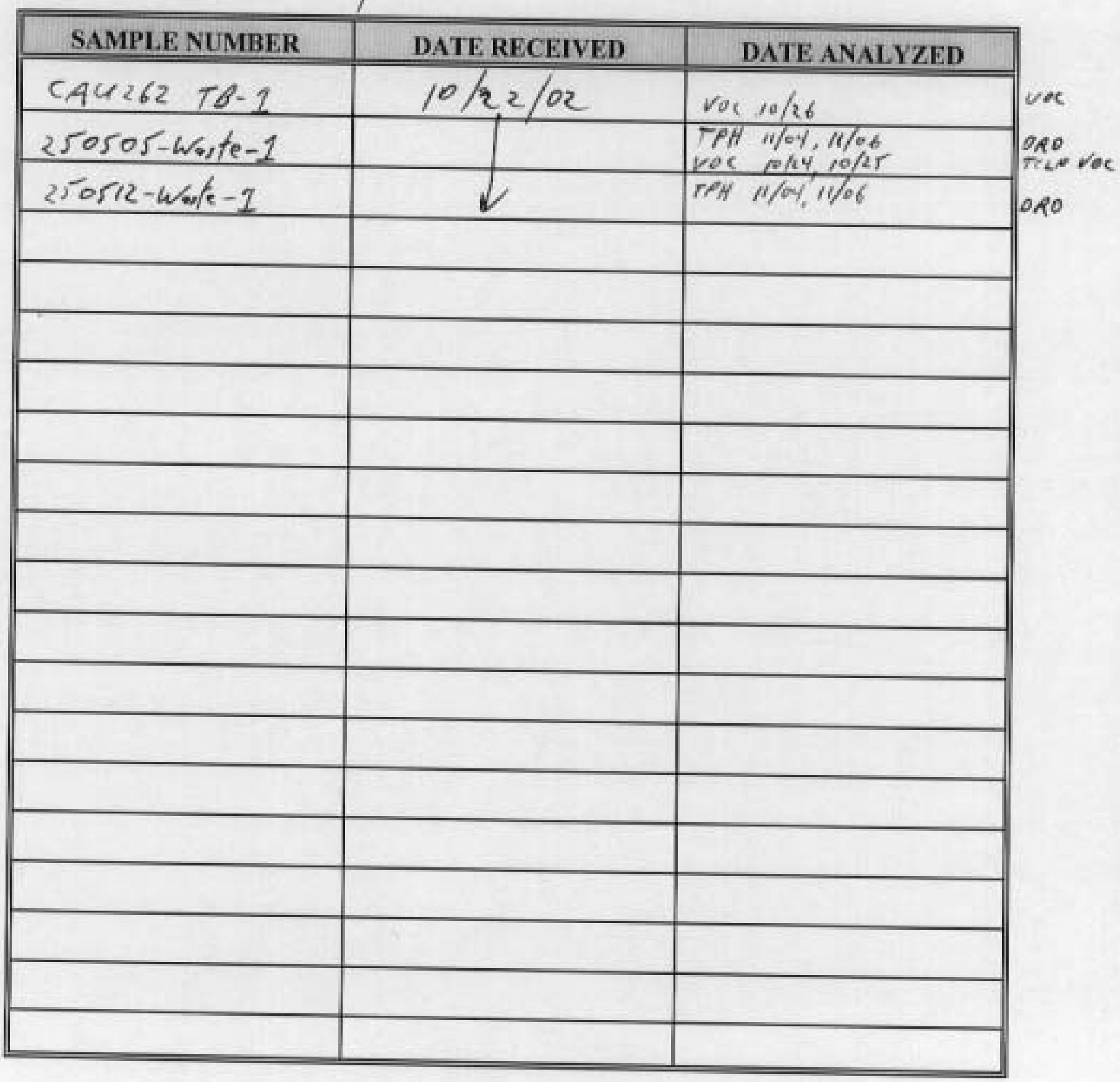




\section{TCLP VOLATILE ORGANIC COMPOUNDS (VOCs)}

\begin{tabular}{|c|c|c|c|c|c||}
\hline PARAMETER & $\begin{array}{c}\text { EXTRACTION } \\
\text { HOLD TIME }\end{array}$ & $\begin{array}{c}\text { ANALYSIS } \\
\text { HOLD TIME }\end{array}$ & $\begin{array}{c}\text { DAYS } \\
\text { HELD }\end{array}$ & $\begin{array}{c}\text { PASS } \\
\text { Y/N }\end{array}$ & $\begin{array}{c}\text { SAMPLES } \\
\text { NOT PASSING }\end{array}$ \\
\hline \hline $\begin{array}{c}\text { TCLP VOCs } \\
\text { EPA Method 8260 }\end{array}$ & Liquids - 7 days & NA & 5 & $Y$ & \\
\hline $\begin{array}{c}\text { TCLP VOCs } \\
\text { EPA Method 8260 }\end{array}$ & NA & Liquids - 40 days & & & \\
\hline Comments: & & & \\
\hline
\end{tabular}

Were extractions done within the hold time limit? \Yes $\square$ No

Were analyses run within the hold time limit?
A. TCLP VOCs reported as: $\square \mathrm{mg} / \mathrm{L}$ or 1 ug/L (liquids) Other:
B. Hits above detection level found in laboratory blank (LB), reagent blank surrogate (RBS), field blank (FB), rinse blank (RB), or other QA samples? Yes No If yes, explain:

C. Did laboratory report indicate any problems? 4 Yes $\mathrm{aNo}$
If 'yes,' explain: Only fer TPH, Ret

D. Were other VOC results reported besides TCLP VOC target compounds? $\square$ Yes 


\section{TOTAL PETROLEUM HYDROCARBONS (TPH)}

\begin{tabular}{|c|c|c|c|c|c|}
\hline PARAMETER & $\begin{array}{l}\text { EXTRACTION } \\
\text { HOLD TIME } \\
\end{array}$ & $\begin{array}{c}\text { ANALYSIS } \\
\text { HOLD TIME } \\
\end{array}$ & $\begin{array}{l}\text { DAYS } \\
\text { HELD } \\
\end{array}$ & $\begin{array}{l}\text { PASS } \\
\mathrm{Y} / \mathrm{N} \\
\end{array}$ & $\begin{array}{c}\text { SAMPLES } \\
\text { NOT PASSING } \\
\end{array}$ \\
\hline $\begin{array}{c}\text { Total TPH } \\
\text { EPA Method } \\
8015 \mathrm{M} \text { or } \\
8015 \mathrm{~B}\end{array}$ & $\begin{array}{l}\text { Liquids - } 14 \text { days } \\
\text { Soils - } 14 \text { days } \\
\text { Oil - } 14 \text { days }\end{array}$ & NA & 14 & & \\
\hline $\begin{array}{c}\text { Total TPH } \\
\text { EPA Method } \\
8015 \mathrm{M} \text { or } \\
8015 \mathrm{~B}\end{array}$ & NA & $\begin{array}{c}\text { Liquids - } 40 \\
\text { days } \\
\text { Soils - } 40 \text { days } \\
\text { Oil - } 40 \text { days }\end{array}$ & 2 & & \\
\hline Comments: & & & & & \\
\hline
\end{tabular}

Was TPH digestion done within the hold time limit? ØYes $\square$ No

Were analyses run within the hold time limit? $\square$ Yes $\square$ No

A. TPH reported as: $\$ \mathrm{mg} / \mathrm{Kg}$ or $\square \mathrm{ug} / \mathrm{Kg}$ Other:

B. Hits above detection level found in LB, RBS, FB, RB, or other QA samples?
If 'yes,' explain:

C. Did laboratory report indicate any problems? $\triangle$ Yes $\square$ No

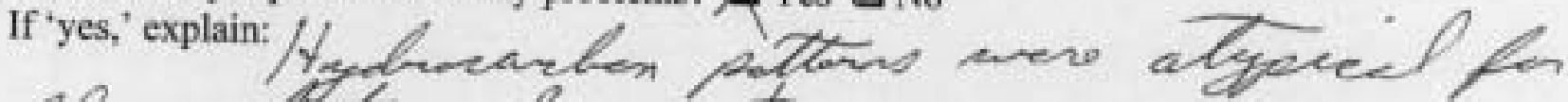

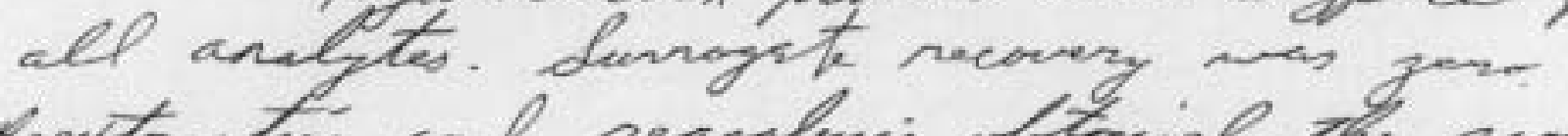

Rexptration and reanalyses whowed the cane result, viduiting a rualup.

leint reguetas lewes

$250512-405 t e \cdot 1$ a

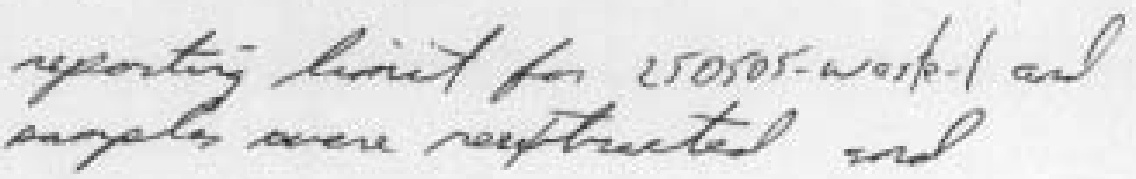
reaselyzed. 


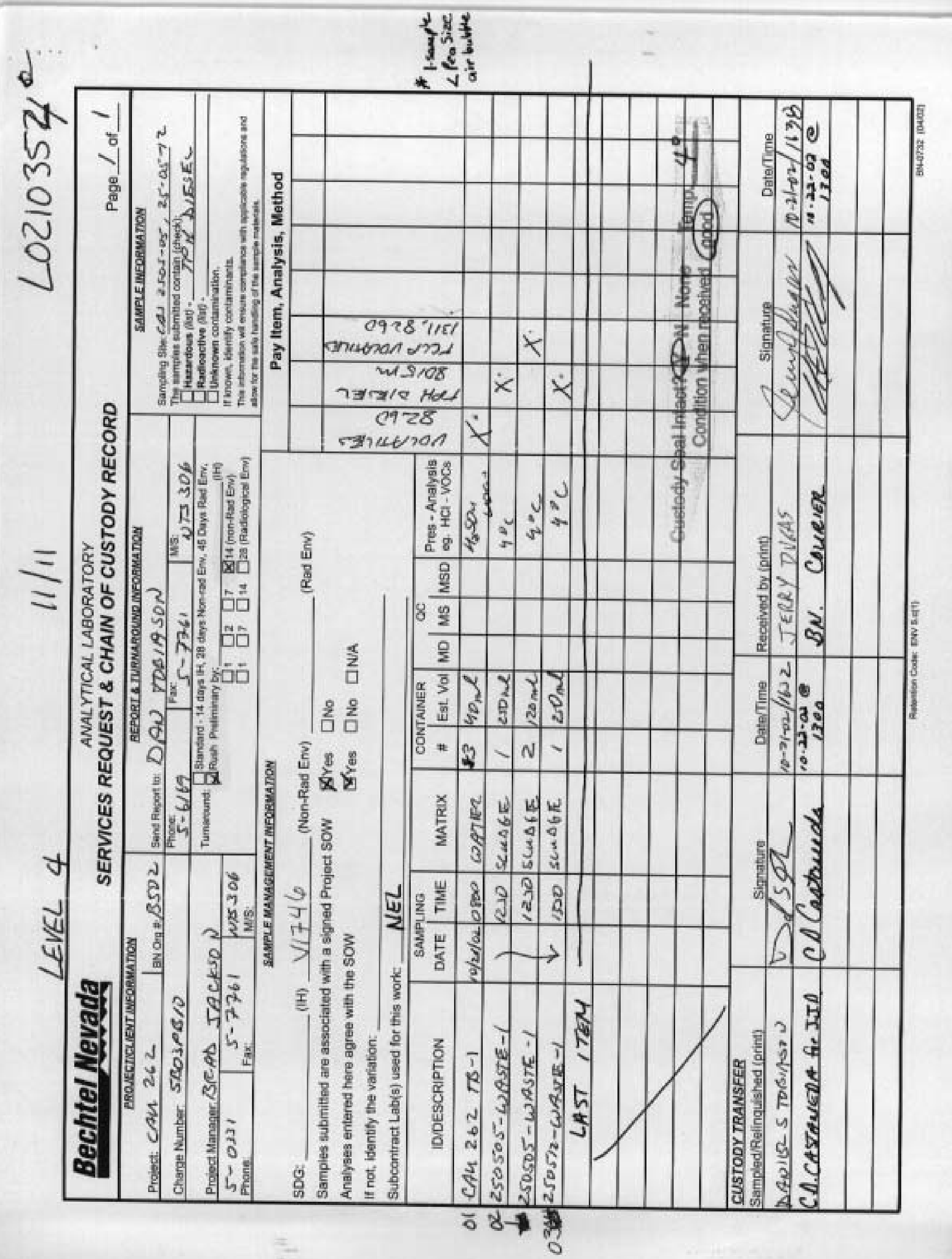


CLIENT: Bechtel Nevada

PROJECT ID: CAU 262

PROJECT \#: $\quad$ B502

MATRIX:
CLIENT ID:

CAU 262 TB-1

DATE SAMPLED: $10 / 21 / 02$

NEL SAMPLE ID: L0210354-001A

\section{Parameter}

1,1,1,2-Tetrachlorocthane

1,1,1-Trichkroethane

1,1,2.2-Tetrachloevethare

1,1,2-Trichloroethane

1,1-Dichloroethane

1.1-Dichloroethene

1.1-Dichloroppropene

1.2.3-Tricklarobenzene

1.2,3-Trichloropropane

1,2,4-Tnichlorobenacne

1.2,4-Trimethylbenzene

1.2-Dibromo-3-chloropropane

1.2-Dibromocthane

1,2-Dichlorobenzene

1,2-Dichlorvecthane

1.2-Dichloropropane

1,3,5-Trimethylhenzene

1.3-Dichlorobenzene

1,3-Dichloropropane

1,4-Dichlomberime

2,2-Dichloropropane

2-Butanome

2-Chlocuethyl vingl ether

2-Chloruteluene

2.Hekanone

4.Chlorobeluese

4-Methyl-2-pentanone

Acetone

Benzene

Bromobenzene

Bromochloromethane

Bromodichloroencthane

Bromoform

Bromoenethane

Carbon disulfide

Cartoen ictrachlaride

Chlorobenzene

Chloroethane

Chlaroform

Chlarenethane

cis-1,2-Dichlorosthene

cis-13-Dichloropropene

Cyclohexane

Dibromochlarontethane

ND - Not Detected at the Repenting Limi

DF - Delution Factor
Reporting

\section{Result Units}

ND we/L

ND $\mu \mathrm{EL}$

ND $\mu E L$

ND $\mu g L$

ND $\mu D^{\prime} \mathrm{L}$

ND $\mu q L$

ND $\mu \mathrm{g} /$

ND Hel.

ND HeL

ND $u{ }^{\prime} L$

ND $\mu 21$

ND $w 2 L$

ND $\mu p / L$

ND $\mu g /$ L

ND $\mu g L$ L

ND $\mu g / L$

ND $\mu \mathrm{g} / \mathrm{L}$

ND $\mu g / 1$

ND $\mu g \tau$

ND $\mu E L$

ND $H E L$

ND $\mu z L$

ND $n g L$

ND $\mu \mathrm{g} / \mathrm{L}$

ND $\mu \mathrm{g} L$.

ND $\mu z L$

ND $u d L$

ND $y^{\prime} L$

ND $a \mathrm{~L}$

ND $\mu \nu L$

ND $\mu g / \mathrm{L}$

ND $\mu q t$

ND $\mu g / L$

ND HgL

ND $\mu \mathrm{g}$ L.

ND $\mu \geqslant l$.

ND $\mu / 1$

ND $\mu g L$

ND agi.

ND $\mu \mathrm{gL}$

ND $\mu E L$

ND $\mu z^{\prime} L$

ND $\mu g$ L.
ND $\mu E L$ L

Date: 14-Nov-02

\begin{tabular}{|c|c|c|c|c|c|}
\hline Limit & DF & Method & Prep Date & Analyzed & Analyst \\
\hline 5.0 & 1 & $5 W 82600$ & & $10 / 20102$ & DRM-LV \\
\hline 50 & 1 & SWK260B & & 1026002 & DRM.LV \\
\hline 50 & 1 & $5 W 1260 B$ & & 1026002 & DRM-LV \\
\hline 50 & 1 & $5 W 8260 \mathrm{~B}$ & & 1002602 & DRM-LY \\
\hline 5.0 & 1 & $5 W 8260 B$ & & $10: 26102$ & DRM-LV \\
\hline 5.0 & 1 & SW8260A & + & 102602 & DRM-LV \\
\hline 5.0 & 1 & $5 W 82608$ & & $10 / 2602$ & DRM-LV \\
\hline 50 & 1 & sws260日 & & 102602 & DRM-LV \\
\hline 50 & 1 & $5 W 82600$ & & $10 / 2602$ & DRM-LV \\
\hline 50 & 1 & sw8200B & & 102602 & DRM-LV \\
\hline 5.0 & 1 & SWB260A & & 1026,02 & DRM-LV \\
\hline 5.0 & 1 & SW8260B & & 102002 & DRM-LV \\
\hline 5.0 & 1 & SWR260B & & 1026002 & DRM-LV \\
\hline 50 & 1 & SWR2tob & & $10 / 2602$ & DRM-LV \\
\hline 5.0 & 1 & SWr260B & & $10 / 2602$ & DRM-LV \\
\hline 50 & 1 & $5 W 8260 B$ & & $10 / 2602$ & DRMALV \\
\hline 5.0 & I & SW82609 & & 1026102 & DRM-LV \\
\hline 5.0 & 1 & SWR2600 & & $10 / 26,02$ & DRMAV \\
\hline 5.0 & 1 & SWR260日 & & $10 / 2602$ & DRM-LV \\
\hline 50 & 1 & $5 W 8260 B$ & & 10260102 & DRM-LV \\
\hline 5.0 & 1 & SW8260B & & 1026002 & DRM-LY \\
\hline 23 & 1 & SW8260B & & $10 / 2602$ & DRM-LV \\
\hline 5.0 & 1 & SW82608 & & 102602 & DRM-LV \\
\hline 50 & 1 & $5 W 82608$ & & 1026002 & DRM-LV \\
\hline 25 & 1 & $5 W 8260 B$ & & $10 / 26012$ & DRM.LV \\
\hline 50 & 1 & SW8260B & & 102602 & DRM-LV \\
\hline 25 & 1 & SW82609 & & 102602 & DRM-LV \\
\hline 25 & 1 & SW82608 & & 102602 & DRM-LV \\
\hline 5.0 & 1 & SW82608 & & 102002 & DRM-LV \\
\hline 5.0 & 1 & SWs260B & & $10 \times 2602$ & DRM-LV \\
\hline 50 & 1 & SW8260B & & 1026602 & DRM-LV \\
\hline 5.0 & 1 & SW8260B & & 102602 & DRM-LV \\
\hline 5.0 & 1 & $5 W 82600$ & & 102602 & DRMAL \\
\hline 5.0 & 1 & SW8260日 & & 1026002 & DRM-LV \\
\hline 5,0 & 1 & SWr260B & & 102602 & DRM-LV \\
\hline 50 & 1 & SWร260B & & 102602 & DRM-EV \\
\hline 5.0 & 1 & SW8260B & & 102602 & DRM-LV \\
\hline 5.0 & 1 & SW82608 & & 102602 & DRM-L.Y \\
\hline 5.0 & 1 & SWR2608 & & 102602 & DRRM-LV \\
\hline 5.0 & 1 & SWR260日 & & 1026002 & DRM-LV \\
\hline 5.0 & 1 & 5w82608 & & 1026002 & DRM-LV \\
\hline 50 & 1 & SW8260B & & $10 / 2602$ & DRM-LV \\
\hline 5.0 & 1 & SW82601 & & $10 / 26702$ & DRM-LV \\
\hline 5.0 & 1 & SW8260B & & 1026102 & DRM-LV \\
\hline
\end{tabular}

B - Analye detected in the associaled Method Blank

S. Splke Recovery outside acceped tecovery limits

E. Valse above quantitation range 
CLIENT: Bechtel Nevada

PROJECT ID: CAU 262

PROJECT \#: $\quad$ B502

MATRIX: AQUEOUS
CliENT ID: $\quad$ CAU 262 TB-1

DATE SAMPLED: $10 / 21 / 02$

NEL. SAMPLE ID! L0210354-001A

\section{Parameter}

Dibromemethane

Dichlorodifluonomethane

Dirsopropyl ether (DIPE)

Ethyl t-butyl ether (ETBE)

Eihylbenzene

Hexachlerobutadiens

Herane

lodomethane

Isopropylbenzene

m,p-Xylene

Methyl Houlyl ether (MTBE)

Methylene chloride

n-Butylbenzerie

n-Propylbenutre

Naphithalene

a-Xyleme

p-lsopropyholuene

sec-flutylbenarene

Styrene

I-Amyl methyl ether (TAME)

1.Butyl aleohol (TBA)

tert-Butylbenaene

Temachlowocthene

Toluene

Total THM

trand-1,2-Dichlorocthene

trans-1,3-Dichluropropene

Trichlorocthene

Trichloroflucromethane

Vimyl acctate

Vinyt chloride

Surrt 4-Bremofleorobenzene

Surr Dibromofluoremethane

Sarr: Toleene-ds

\begin{tabular}{|c|c|c|c|c|}
\hline Result & Units & Limit & DF & Method \\
\hline ND & $\mu g$ 'L & 5.0 & 1 & SWY2608 \\
\hline ND & $\mu g /$ & 5.0 & 1 & SW82600 \\
\hline ND & $\mu \mathrm{e} t$ & 5.0 & 1 & SWK260日 \\
\hline ND & $\mu E \mathrm{~L}$ & so & 1 & SW8260B \\
\hline ND & $H E L$ & 50 & 1 & SW8260B \\
\hline ND & $\mu \% \mathrm{~L}$ & 5.0 & 1 & sw8ze0B \\
\hline ND & $\mu g / L$ & 5.0 & t & $5 W 82608$ \\
\hline ND & $\mathrm{HBL}$. & 5.0 & 1 & SW8260B \\
\hline ND & $\mid \omega E L$ & so & 1 & sW8260日 \\
\hline ND & $M g L$ & 10 & 1 & $5 W 8260 B$ \\
\hline ND & $M z^{\prime} L$ & 50 & 1 & SW8260B \\
\hline ND & $\mu \mathrm{g} / \mathrm{L}$ & 5.0 & 1 & SWB260B \\
\hline ND & $\mathrm{Net}$ & 5.0 & 1 & SW82600 \\
\hline ND & $\mu \mathrm{el}$ & 5.0 & 1 & 5พк260日 \\
\hline ND & uel & 10 & 1 & sw8260B \\
\hline ND & $\mu g /$ & 5.0 & 1 & Sw8260B \\
\hline ND & $\mu g / 2$ & 50 & 1 & SW8260B \\
\hline ND & $\mu \mathrm{gL}$ & 5.0 & 1 & SW82608 \\
\hline ND & HeL 2 & 5.0 & 1 & sw82608 \\
\hline ND & $\mathrm{kg} / \mathrm{L}$ & 5.0 & 1 & SWR2600 \\
\hline ND & $\mu E L$ & 50 & 1 & SWs260B \\
\hline ND & $\mu E \mathrm{~L}$. & 50 & 1 & 5W8260B \\
\hline $\mathrm{ND}$ & HeL & 5.0 & 1 & sw8200B \\
\hline ND & 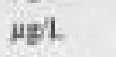 & 5.0 & 1 & 5W8260B \\
\hline ND & AgI. & 5.0 & 1 & 5W82608 \\
\hline ND & Het. & 5.0 & 1 & 5WB260日 \\
\hline ND & uger. & 5.0 & 1 & sw8260日 \\
\hline $\mathrm{ND}$ & $\mu \mathrm{gt}$ & 50 & 1 & 5W8260B \\
\hline ND & $\mu g / L$ & 50 & 1 & SWa260B \\
\hline ND & $\mu g /$ & 5.0 & 1 & SW82601 \\
\hline ND & $\mu \mathrm{g} L$ & 5,0 & $t$ & SWE260日 \\
\hline 86.1 & ЖHEC & 71.7 .120 & 1 & 5W82608 \\
\hline 90.2 & \%REC & $802-106$ & 1 & sw8260B \\
\hline 993 & \%REC & $75.5-101$ & 1 & SW826oB \\
\hline
\end{tabular}

\section{Prep Date}

Analvzed

$10 / 26 / 02$

$10 / 26,02$

102602

102602

102602

102602

$10 / 2602$

102602

102602

102602

$10 / 2602$

102602

1026102

10/26:02

$10 / 2602$

$10 \times 2602$

$10 / 2602$

1026102

102602

$10 / 2602$

102602

10/2602

102602

10/2602

$10 / 2602$

102602

102602

$10 / 2602$

102602

102602

1026,02

$10 / 2602$

102602

10/26:02
Analyst

DRM-LV

DRM-LV

DRM-LV

DRM-LV

DRM-LV

DRM-LV

DRM-LY

DRM-LV

DRM-IV

DRM-L.V

DRM-LV

DRM-LV

DRM-LV

DRM-LV

DRM-LV

DRM-LV

DRM-LV

DRM-L.

DAR-LV

DRM-LV

DEM-LV

DRM-LV

DRM-LV

DRM-LV

DRM-LV

DRM-LV

DRM-LV

DRM-LV

DRM-LV

DRM-LY

DAM-LV

DEM.LV

DRM.LV

DRM-LV
ND - Not Detected at the Reporning Limin

DF - Diletian Factor
B + Analye detected in the associated Method Blank

S - Spike Recovery oubide acceped recovay limits

E- Value above quantitation tange 


$\begin{array}{llll}\text { CLIENT: } & \text { Bechtel Nevada } & \text { CLIENT ID: } & \text { 250505-Waste-1 } \\ \text { PROJECT ID: } & \text { CAU } 262 & \text { DATE SAMPLED: } 1021 / 02 \\ \text { PROJECT H: } & \text { B502 } & \text { NEL SAMPLE ID: L0210354-002A } \\ \text { MATRIX: } & \text { SLUDGE } & \end{array}$

Parameter
Diesel Range Organics (C12-C22)
Gasoline Range Organics (CS-C12)
Oil Range Organies (C22-C34)
Total Petroleum Hydrocarbons
Surr: a-Octacosane

\begin{tabular}{|c|c|}
\hline Result & $\underline{\text { Units }}$ \\
\hline ND & $m Q K_{z}$ \\
\hline 100 & $\operatorname{meg} / K_{2}$ \\
\hline 390 & $\mathrm{me} / \mathrm{Kg}$ \\
\hline 490 & $\mathrm{~m} \equiv / \mathrm{Kg}$ \\
\hline 34.0 & *REC \\
\hline
\end{tabular}

\section{Reporting}

Limit

60

60

150

60

$55-130$

\section{DF}

I

1 SWe015lixt

1 SWEOISExt

1 SWrolsExt

1 SWrotstat

I SWgotsEx

\begin{tabular}{l} 
Prep Date \\
\hline 11,0402 \\
110402 \\
110402 \\
$11 / 04 / 02$ \\
$11 / 04 / 02$
\end{tabular}

Analyzed

$11 / 0602$

$11 / 0602$

$11 / 0602$

110602

$11106 \mathrm{n} 2$
Analyst

COP-LV COP.LY copuly COPLV COP-LY
ND - Not Detected at the Reperting Limit DF - Dilation Factor

Date: 14-Now-02
B - Analyte detested in the associated Methed Blank

S-Spike Recovery outside acceptrd recovery limits

E- Value above qantitation range 


\begin{tabular}{|c|c|c|}
\hline CLIENT: & Bechtel Nevada & 250505-Waste-1 \\
\hline PRO.JECT ID: & CAU 262 & DATE SAMPLED: $10 / 21 / 02$ \\
\hline PROJECT \#: & B502 & NEL SAMPLE ID: L0210354-002B \\
\hline MATRIX: & SLUDGE & \\
\hline
\end{tabular}

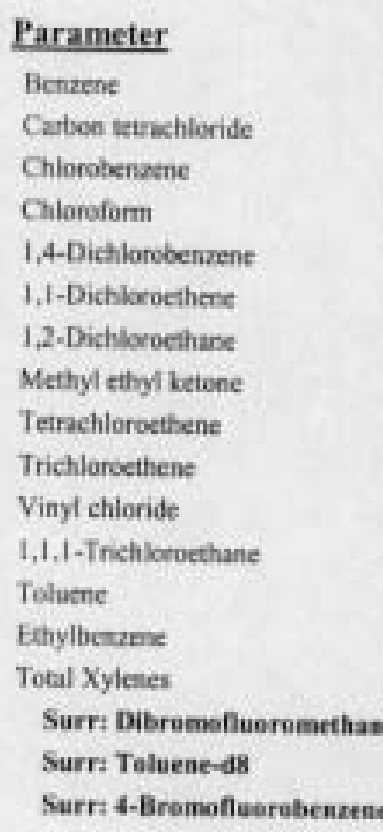

\begin{tabular}{|c|c|}
\hline Result & Units \\
\hline $\mathrm{ND}$ & mgl. \\
\hline ND & $\mathrm{mgl}$ \\
\hline ND & mel. \\
\hline ND & ngt. \\
\hline ND & $\mathrm{mgl}$ \\
\hline ND & $\mathrm{mg} / \mathrm{L}$ \\
\hline ND & $\mathrm{mg} / \mathrm{L}$ \\
\hline ND & $\mathrm{mgl}$. \\
\hline ND & $\mathrm{mg} / \mathrm{L}$ \\
\hline ND & $m e t$ \\
\hline ND & $\mathrm{mgl}$ \\
\hline ND & mgl \\
\hline ND & $\mathrm{mg} / \mathrm{L}$ \\
\hline ND & $\mathrm{mg} / \mathrm{L}$ \\
\hline ND & $m g / L$ \\
\hline 87.6 & ЖREC \\
\hline 99.6 & FREC \\
\hline 82.0 & AREC \\
\hline
\end{tabular}

\section{Reporting}

\section{Limit}

0.10

0.10

0.10

0.10

0.10

0.10

0.10

0.50

0.10

0.10

0.10

0.10

6.10

0.10

0.20

$74-3-132$

81. $3-138$

$58.4-154$

\begin{tabular}{ll} 
DF & Method \\
\hline 20 & TCLP 8260 \\
20 & TCLP 8260 \\
20 & TCLP 8260 \\
20 & TCLP 8260 \\
20 & TCLP 8260 \\
20 & TCLP 8260 \\
20 & TCLP 8260 \\
20 & TCLP 8260 \\
20 & TCLP 8260 \\
20 & TCLP 8260 \\
20 & TCLP 8260 \\
20 & TCLP 8260 \\
20 & TCLP 8260 \\
20 & TCLP 8260 \\
20 & TCLP 8260 \\
20 & TCLP 8260 \\
20 & TCLP 8260 \\
20 & TCLP 8260
\end{tabular}

Prep Date

$10 / 2402$

$10 / 2402$

1024,02

$10 / 24 / 02$

102402

102402

102402

10/24n2

102402

$10 / 2402$

1024,02

$10 / 24 / 02$

1012402

1002402

1024002

1024,02

10/24:02

$10 / 24 / 02$

\begin{tabular}{|c|}
\hline Analvzed \\
\hline 1025502 \\
\hline $10 / 25: 02$ \\
\hline $10 / 25.02$ \\
\hline $10 / 25 / 02$ \\
\hline $10 / 25 / 02$ \\
\hline 102502 \\
\hline $1025 \times 12$ \\
\hline $1025: 02$ \\
\hline 1025,02 \\
\hline $10 / 25 i 02$ \\
\hline 1025102 \\
\hline $10 \sqrt{25} 102$ \\
\hline 10/25/02 \\
\hline $10 / 25,02$ \\
\hline $10 / 25,02$ \\
\hline $10 / 25 / 02$ \\
\hline $10 / 25 i 02$ \\
\hline $10 / 25 / 02$ \\
\hline
\end{tabular}

Analyst

DRM-LV

DRM-LV

DEM-LV

DRM-LV

DRM.LV

DRM-L.V

DRM-LV

DHM-LV

DRM-LV

DRM-LV

DRM-LV

DRM-LV

DRM-LV

DRM-LV

DRM-LV

DRM-LV

DRM-LV

DRM-LV
ND - Not Detected at the Reporting Limit

DF - Dilution Factor

Date: I 4-Now-02
B-Analyte detceted in the aseociated Methad Blank

S. Spike Recovery outside aecepted recovery limits

E. Value above quantitation range 


\begin{tabular}{|c|c|c|c|}
\hline CLIENT: & Bechtel Nevada & CLIENT ID: & 250512-Waste-1 \\
\hline PROJECT ID: & CAU 262 & DATE SAMPLED: & $10 / 21 / 02$ \\
\hline PROJECT A: & B502 & NEL SAMPLE ID: & L0210354-003A \\
\hline MATRIX: & SLUDGE & & \\
\hline
\end{tabular}

\begin{tabular}{|c|c|c|c|c|c|c|c|c|c|}
\hline Parameter & $\underline{\text { Result }}$ & $\underline{\text { Units }}$ & & $\begin{array}{l}\text { Reporting } \\
\text { Limit }\end{array}$ & $\underline{D F}$ & Method & Prep Date & Analyzed & Analyst \\
\hline Diesel Rasge Organies (C12-C22) & 1100 & $\mathrm{me} / \mathrm{Ke}$ & F3 & $\omega$ & 1 & SW9015Ext & $11 / 0402$ & $11 / 06102$ & COP.LV \\
\hline Gasoline Range Orzanies (Ca-C12) & 83 & $\mathbf{m g} / \mathrm{K}_{\mathrm{g}}$ & F1 & 60 & 1 & SWY015Ext & $11 / 0402$ & 110602 & COP-LV \\
\hline Oll Range Organics (C22-C34) & ND & $m g / K_{g}$ & & 150 & 1 & SWYDISEAt & $11 / 0402$ & 110602 & COP-LV \\
\hline Total Petraleam Hydrocarbons & 1200 & $\mathbf{m g} / \mathbf{K}_{\mathrm{t}}$ & & 60 & 1 & SWROLSEXI & $11 / 0402$ & 1110602 & COP-LV \\
\hline Surr: 1-Oktacosane & 62.1 & \%REC & & 55.130 & 1 & 5W8015Ext & 11,0402 & 110602 & COP.LV \\
\hline
\end{tabular}


CLOSURE RE PORT - CAU 262

Section: Appendix B

Revision : 1

Date: July 2003

\section{THIS PAGE INTENTIONALLY LEFT BLANK}


225 Commerce Drive $\bullet$ Fort Collins, CO $80524 \bullet(800)$ 443-1511 $\bullet(970)$ 490-1511 $\bullet$ FAX (970) 490-1522

November 15, 2002

Mr. Ted Redding

Bechtel Nevada

US DOE Zone 1, Bldg. 652

Rm. 2, M/S NTS273

Mercury, NV 89023

RE: Paragon Workorder: 02-10-144

Client Project Name: CAU 262

Client Project Number: V1747

Dear Mr. Redding:

One liquid and sludge sample was received from Bechtel Nevada on October 25, 2002

The sample was scheduled for the following analyses

Gross Alpha/Beta

Gamma Spectroscopy-liquid

pages 1-243

Gamma Spectroscopy-sludge

pages 1-104

pages $1-96$

The results for these analyses are contained in the enclosed reports.

Thank you for your confidence in Paragon Analytics, Inc. Should you have any questions, please call.

Sincerely,

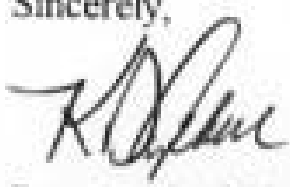

Paragon Analytics, Inc.

Ken Campbell

Project Manager

KDC/hc

Enclosure: Report 


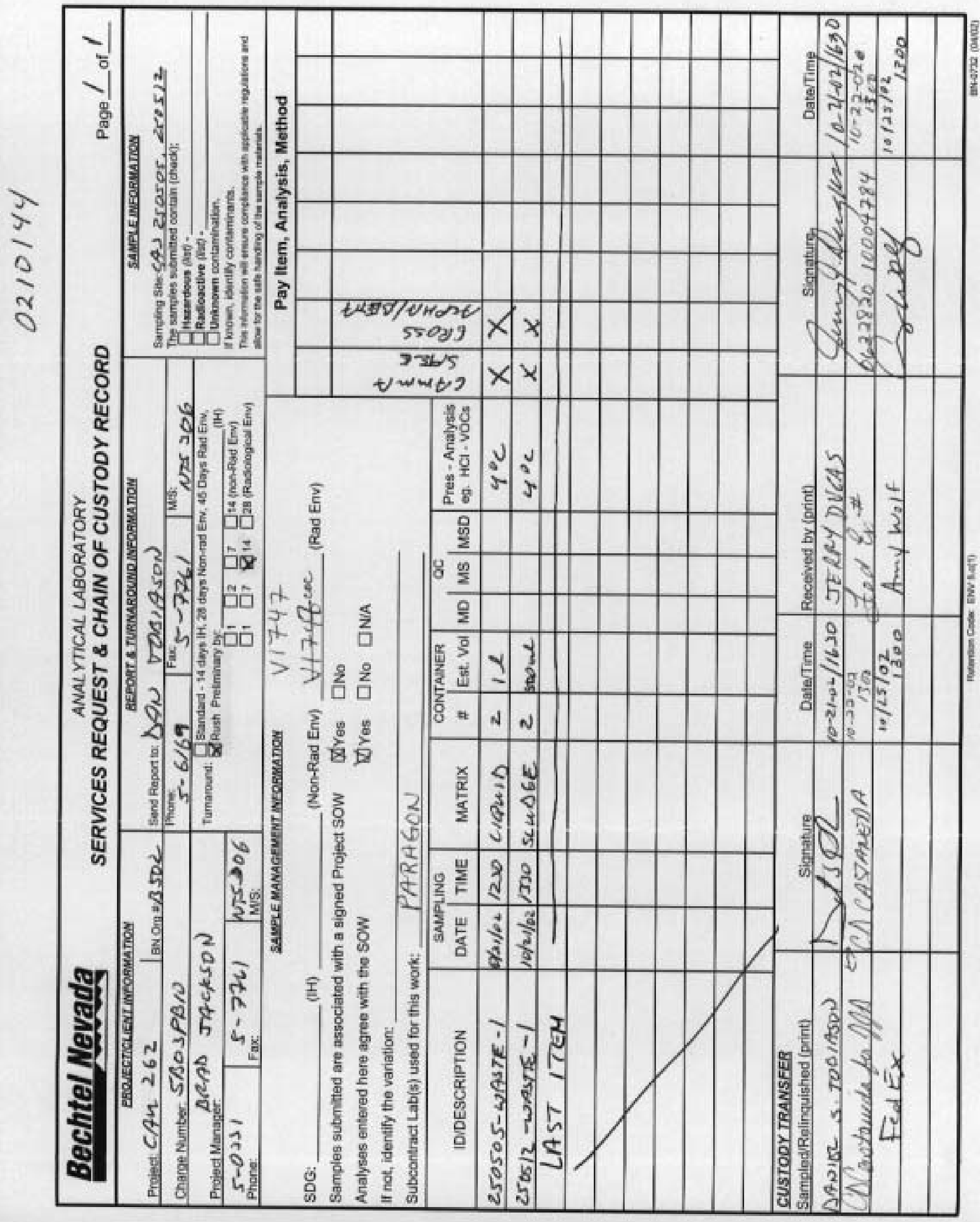




\section{Paragon Analytics, Inc. Radiochemistry Case Narrative Gross Alpha/Beta}

\section{Bechtel Nevada \\ CAU 262 / V1747 \\ PAI WO 0210144}

1. This report consists of one liquid sample and sludge sample received by Paragon on 10/25/02.

2. Sample 250505-WASTE-1 (PAI ID 0210144-1) was received with a pH of 7. Due to the high levels of suspended solids, acidification was not attempted prior to analyses. Please refer to QASS 246103.

3. These samples were prepared according to Paragon Analytics, Inc, procedure PAI SOP702R15.

4. The samples were analyzed for gross alpha and beta activity by gas flow proportional counting according to Paragon Analytics, Inc, procedure PAI SOP724R7. The analyses were completed on $11 / 08 / 02$. Gross alpha results are referenced to ${ }^{241} \mathrm{Am}$. Gross beta results are referenced to ${ }^{90} \mathrm{Sr} / \mathrm{Y}$.

5. The analysis results for the sludge sample are reported on a dry weight basis in units of pCi/gram.

6. The analysis results for the liquid sample are reported in units of $\mathrm{pCi} / \mathrm{L}$. The sample was not filtered prior to analysis.

7. The sludge sample was flamed, as prescribed in EPA Methods 900.0 and 9310 for samples which demonstrate hygroscopicity. This could reduce the beta activity if the samples contained ${ }^{137} \mathrm{Cs}$, or other beta emitters, that may be volatile under the conditions associated with flaming.

8. Following an extended count the requested MDC for gross alpha/beta for sample 250505WASTE-1 and its duplicate (PAI ID 0210144-1 and -1-D1) were not achieved due to the presence of elevated levels of dissolved / suspended solids native to the sample. The requested method limits the amount of sample solids residue taken for analysis to 5 $\mathrm{mg} / \mathrm{cm}^{2}$. These samples are identified with an " $\mathrm{M}$ " flag on the Gross AlphaBeta Raw Data Report, which can be found in Section 4, "Raw Data" of this report. The reported gross alpha/beta activity for theses samples exceeds the achicved MDC. 
9. Due to current software limitations, the DER determinations in this report were calculated using the 2 sigma TPU. The SOW indicates that the 1 sigma TPU be used in the DER determination. However, the requested DER limit of less than 3 at the 1 sigma level (which is equivalent to 1.5 at the 2 sigma level) was achieved. Data quality is not affected.

10. No further anomalous situations were noted during the preparation and analysis of these samples. All remaining quality control criteria were met.

The data contained in the following report have been reviewed and approved by the personnel listed below. In addition, Paragon Analytics, Inc. certifies that the analyses reported herein are true, complete and correct within the limits of the methods employed.
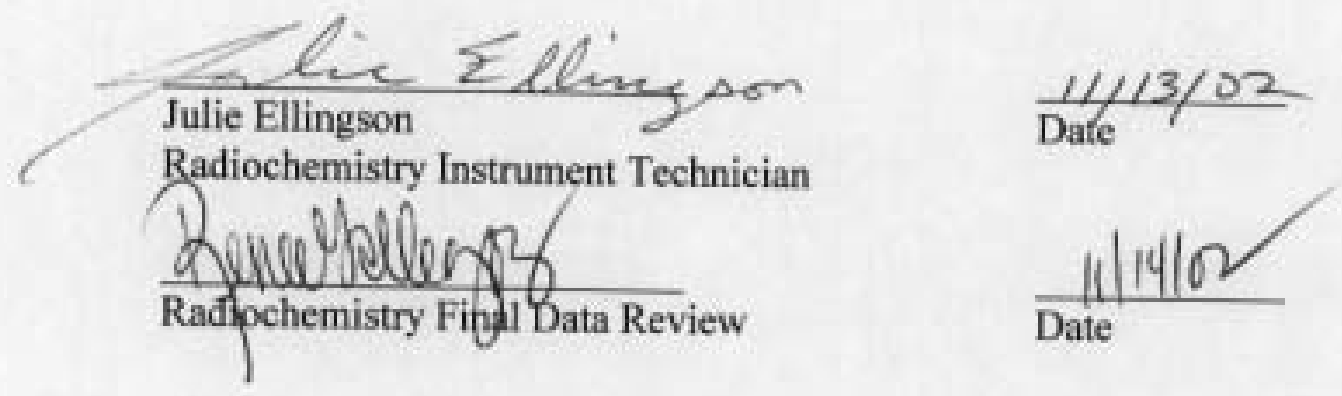


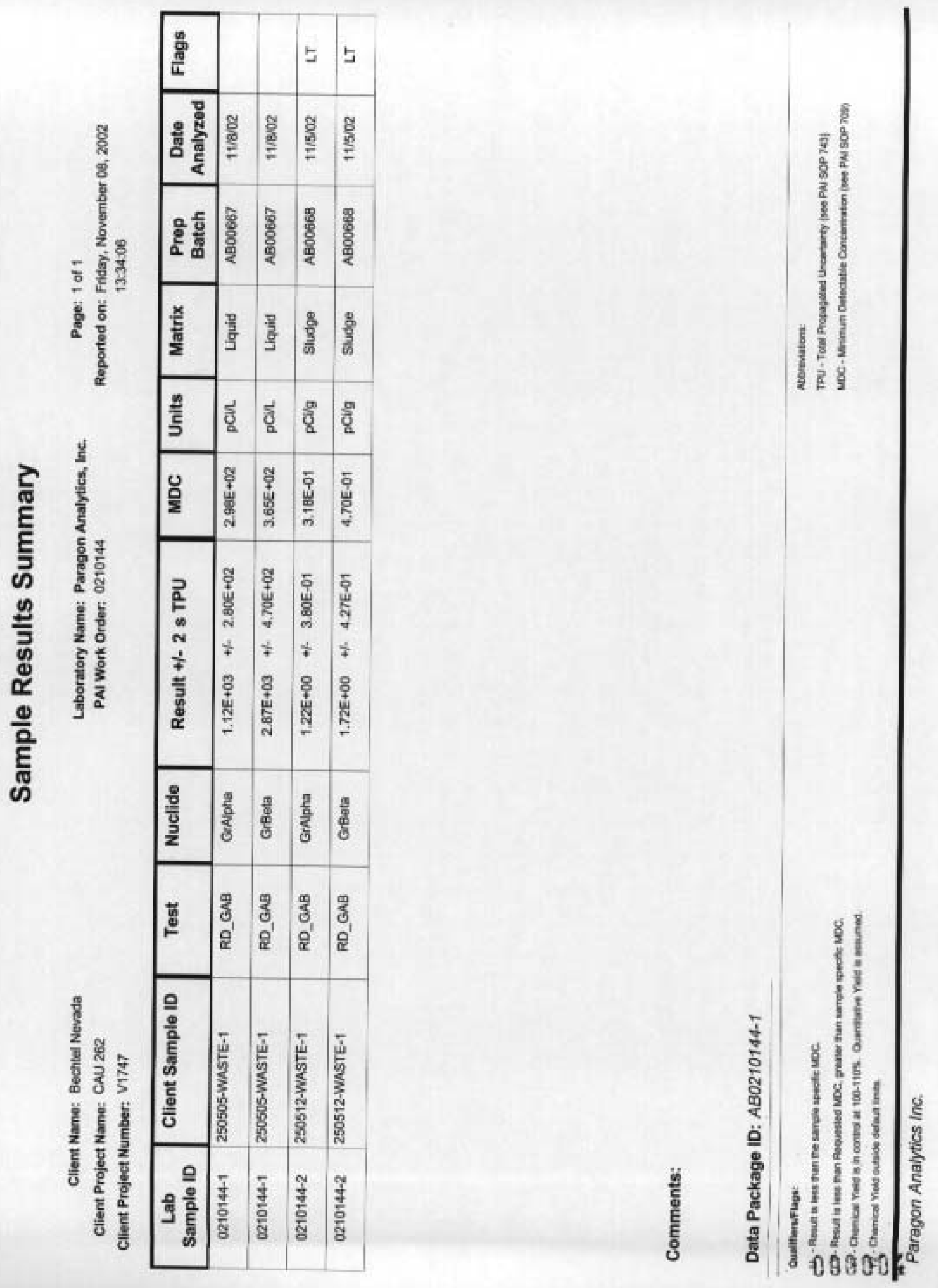




\section{Paragon Analytics, Inc. Radiochemistry Case Narrative Gamma Spectroscopy}

\section{Bechtel Nevada \\ CAU 262 / V1747}

Paragon Work Order 0210144

1. This report consists of analysis results for one sludge sample received by Paragon on $10 / 25 / 02$. The analysis results for this sample are reported on an 'as received' basis in units of $\mathrm{pCi} / \mathrm{gram}$.

2. This sample was prepared according to Paragon Analytics, Inc, procedure PAI SOP739R5.

3. The sample was analyzed for the presence of gamma emitting radionuclides according to Paragon Analytics, Inc. procedure PAI SOP713R7. The analyses were completed on 10/29/02.

4. The sample was analyzed using Seeker Version 2.2, which is a product of Vertechs Software Solutions, Inc.

5. Sample volumes were insufficient to allow preparation of a duplicate. A duplicate analysis of sample 250512-WASTE-1 (PAI ID 0210144-2) was performed in lieu of a preparation duplicate.

6. Due to current software limitations, the DER determinations in this report were calculated using the 2 sigma TPU. The SOW indicates that the 1 sigma TPU be used in the DER determination. However, the requested DER limit of less than 3 at the 1 sigma level (which is equivalent to 1.5 at the 2 sigma level) was achieved. Data quality is not affected.

7. The efficiencies used in the activity calculations for these samples were obtained using a NIST traceable mixed gamma source spiked into $500 \mathrm{~g}$ of sand. Due to differences between the calibration standard and the samples, the analytical results may be biased.

8. There are cases where the magnitude of the negative activity is greater than the 2 sigma TPU. The analyst's review of the data does not indicate a problem with the instrument data or the subsequent reporting systems. The data quality is not believed to be affected and the results are submitted without qualification. Under typical conditions, where background level sample data is normally distributed and analyzed by paired observations, this event is likely to occur at least $2.5 \%$ of the time.

9. No problems were encountered with either the client samples or the associated quality control samples. All quality control criteria were met. 
The data contained in the following report have been reviewed and approved by the personnel listed below. In addition, Paragon Analytics, Inc, certifies that the analyses reported herein are true, complete and correct within the limits of the methods employed.
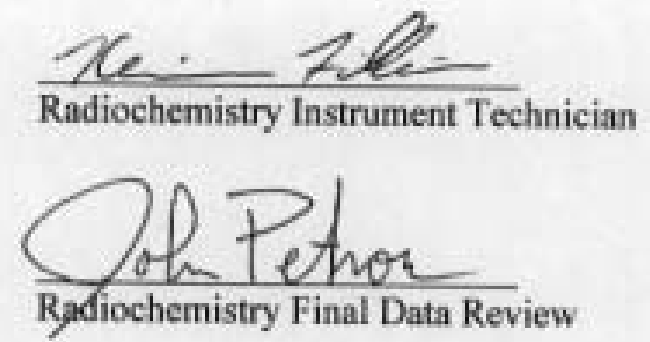

$$
11-8-02
$$

Date

$\frac{11 / 8102}{110}$ 


\section{Gamma Spectroscopy Results}

\section{Method PAI 713R7}

\section{Sample Results}

Client Name: Bechtel Nevada

Client Project Name: CAU 262

Client Project Number: V1747
Page: 1 of 2

Reported on: Thursday, November 07, 2002

$15 \times 42.40$

Laboratory Name: Paragon Analytics, Inc.

PAI Work Order: 0210144
Field 10:250505-WASTE-1

Lab ID:0210144-1
Sample Matrix: Liquid

Date Prepared: 29-Oct-02

Prep SOP: PAI $730 R 5$

Prep Batch: GS01753
Date Collected: 21-Oct-02

Date Analyzed: 30-Oct-02

Analytical SOP: PAI 713R7

Spectrum Code: 021146007A
Final Aliquot: $1.000 \mathrm{~L}$

Report Basis: As Received

Count Time (min.): 300

Library: GAM-A-001.U

\begin{tabular}{|c|c|c|c|c|}
\hline Target Nuclide & Result + +1 - 2 TPU & MDC & $\begin{array}{c}\text { Reporting } \\
\text { Units }\end{array}$ & Lab Qualifier \\
\hline Ac- 228 & $3.05 E+01+i-2.21 E+01$ & 3.35E+01 & pCin & $u$ \\
\hline Am-241 & $-2.92 E+00+i=5.64 E+00$ & $9.84 E+00$ & pCin. & $\mathrm{u}$ \\
\hline $\mathrm{Ce}-144$ & $-1.88 E+01+/-1.92 E+01$ & $3.38 E+01$ & pCin & $u$ \\
\hline Co-60 & $-1.40 E+00+/-5.53 E+00$ & $1.02 E+01$ & pCiL & $u$ \\
\hline C5-134 & $6.36 E-01+\%-5.11 E+00$ & $8.77 \mathrm{E}+\infty$ & pCir. & $u$ \\
\hline Cs-137 & $1.12 E+02+1-2.13 E+01$ & $8.52 E+\infty 0$ & $\mathrm{pCu}$ & \\
\hline Eu-152 & $+8.09 E+D 0+1-2.84 E+01$ & $5.26 E+01$ & $\mathrm{pCil}$ & $\mathrm{U}$ \\
\hline Eu-154 & $5.50 E+00+\div-2.83 E+01$ & $4.94 E+01$ & $\mathrm{pCUL}$ & U \\
\hline Eu-155 & $-2.84 \mathrm{E}+00+9.23 \mathrm{E}+00$ & $1.60 E+01$ & pCil & $\mathbf{u}$ \\
\hline$K-40$ & $2.96 \mathrm{E}+02+1-1.21 \mathrm{E}+02$ & $1.61 \mathrm{E}+02$ & pCill & \\
\hline $\mathrm{Pb}-212$ & $3.12 E+01+1-1.10 E+01$ & $1.47 E+01$ & pCiL & \\
\hline$P m-144$ & $3.97 E+00+5.17 E+00$ & 8.45E+00 & DCIL & $u$ \\
\hline$P m=146$ & $-2.23 E+00+6.6 .12 E+00$ & $1.08 E+01$ & peirl & $U$ \\
\hline Ru-106 & $-1.97 E+01+4-4.55 E+01$ & 8. $14 E+01$ & pCir & $u$ \\
\hline$S b-125$ & $2.64 \mathrm{E}+00+f-1.30 \mathrm{E}+01$ & $2.21 E+01$ & $\mathrm{pCIh}$ & $u$ \\
\hline Th-234 & 8.65E+01 */- 6.84E+01 & $1,09 E+02$ & $\mathrm{pCl}$ & $U$ \\
\hline U.235 & $3.16 E+00+i-2.51 E+01$ & $4.23 \mathrm{E}+01$ & pCil & U \\
\hline$Y-98$ & $4.37 E+60+\%-5.30 E+00$ & $8.59 E+00$ & pCil & u \\
\hline
\end{tabular}

Data Package ID: GSW0210144-1 


\section{Gamma Spectroscopy Results}

\section{Method PAI 713R7}

\section{Sample Results}

Client Name: Bechitel Nevada

Client Project Name: CAU 262

Client Project Number: V1747
Page: 2 of 2

Reported on: Thursday, Nowember 07, 2002 15:42:40

Laboratery Name: Paragon Analytics, Inc. PAI Work Order: 0210144
Field ID:250505-WASTE-1

Lab ID:0210144-1
Sample Matrix: Liquid

Date Prepared: 29-0ct-02

Prep SOP: PAI 739R5

Prep Batch: GS01753
Date Collected: 21-Oct-02

Date Analyzed: 30-0ct-02

Analytical SOP: PAI 713R7

Spectrum Code: 021146007A
Final Aliquot: $1.000 \mathrm{~L}$

Report Basis: Aa Received Count Time (min.): 300

Library: GAN-A-COLLI

\begin{tabular}{|c|c|c|c|c|}
\hline Target Nuclide & Result $+1-2$ s TPU & MDC & $\begin{array}{c}\text { Reporting } \\
\text { Units }\end{array}$ & Lab Qualifier \\
\hline
\end{tabular}

\section{Comments:}

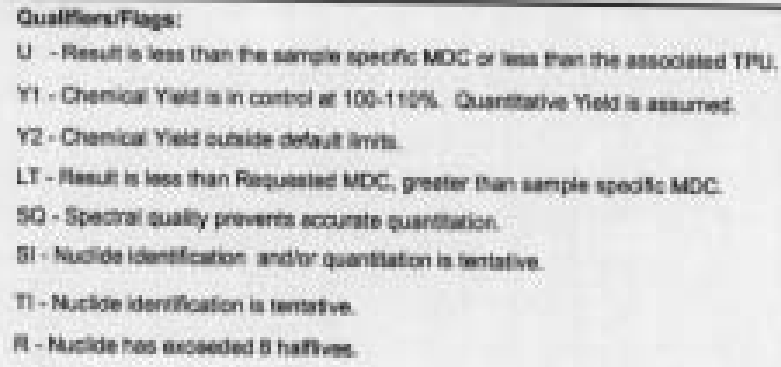

\section{Atbeviaser:}

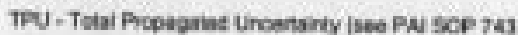

MOC - Mrinum Detectabie Concerbaten (ses PN SOp rov) 


\section{Gamma Spectroscopy Results}

\section{Method PAI 713R7}

\section{Sample Results}

Client Name: Bechtel Nevada

Client Project Name: CAU 262

Client Project Number: V1747
Page: 1 of 2

Reported on: Friday, Nowember 08, 2002 00:11:21

Laboratory Name: Paragon Analytics, Inc.

PAl Work Order: 0210144
Field ID:250512-WASTE-1

Lab ID:0210144-2
Sample Matrix: Sludge

Date Prepared: 29-0ct-02

Prep SOP: PAI 73aR5

Prep Batch: GS01754
Date Collected: 21-0ct-02

Date Analyzed: 29-Oct-02

Analytical SOP: PAI 713R7

Spectrum Code: 021141D07A
Final Aliquot: $347.1 \mathrm{~g}$

Report Basis: As Received Count Time (min.): 30

Library: GAM-AOOHLI

\begin{tabular}{|c|c|c|c|c|}
\hline Target Nuclide & Result +/- 2 s TPU & MDC & $\begin{array}{c}\text { Reporting } \\
\text { Units }\end{array}$ & Lab Quallifier \\
\hline$A c-228$ & $8.90 \mathrm{E}-02+1-2.34 \mathrm{E}-01$ & 4.26E-01 & $\mathrm{pClig}$ & $u$ \\
\hline $\mathrm{Am}=241$ & $5.20 \mathrm{E}-02+8.04 \mathrm{E}-02$ & $1.34 \mathrm{E}-01$ & pCing & $u$ \\
\hline Ce-144 & $1.19 E-01 * 2.00 E-01$ & $3.38 \mathrm{E}-01$ & $\mathrm{pClg}$ & $u$ \\
\hline $\mathrm{C}_{0}-60$ & $3.42 E-02+5.61 E-02$ & 9.57E-02 & $\mathrm{pClig}$ & $u$ \\
\hline Cs-134 & $-1.12 \mathrm{E}-02+i-5.71 \mathrm{E}-02$ & 1.13E-01 & $\mathrm{pClg}$ & $u$ \\
\hline Cs-137 & $1.13 E+00+1-2.65 E-01$ & $1.24 E-01$ & pCig & \\
\hline Eu-152 & $1.08 E-01+1-2.64 E-01$ & 5.00E-01 & pCilg & U \\
\hline Eu-154 & $-4.68 \mathrm{E}-02+3-3.38 \mathrm{E}-01$ & 7.03E-01 & pCing & $u$ \\
\hline Eu-155 & $7.05 E-02+1.17 \mathrm{E}-01$ & $1.96 E-01$ & pCing & $u$ \\
\hline$K-40$ & $7.02 E-01+1-9.98 E-01$ & $1.65 E+00$ & $\mathrm{pCi} / \mathrm{g}$ & $u$ \\
\hline $\mathrm{Pb}-212$ & 8. $39 \mathrm{E}-02++1.05 \mathrm{E}-01$ & $1.70 E-01$ & $p C \mathrm{Cing}$ & $\mathrm{u}$ \\
\hline Pm-144 & $3.77 \mathrm{E}-02 * 5.93 \mathrm{E}-02$ & 1.26E-01 & $\mathrm{pClig}$ & $u$ \\
\hline Pm-146 & $4.92 \mathrm{E}-02 * 8.88 \mathrm{E}-02$ & $1,51 E-01$ & $\mathrm{pCl} g$ & $u$ \\
\hline$R u-106$ & $3.45 \mathrm{E}-01+1.5 .66 \mathrm{E}-01$ & $9.59 E-01$ & $\mathrm{pCl} / \mathrm{g}$ & $u$ \\
\hline$S b-125$ & $9.27 \mathrm{E}-02+1-1.72 \mathrm{E}-01$ & $2.92 \mathrm{E}-01$ & $\mathrm{PCl}_{\mathrm{g}}$ & $\mathrm{u}$ \\
\hline Th-234 & 1. $.98 E-01+6.5 .69 E-01$ & $9.87 \mathrm{E}-01$ & $\mathrm{pCV}_{\mathrm{g}}$ & $u$ \\
\hline U.235 & $1.38 \mathrm{E}-01+2.64 \mathrm{E}-01$ & $4.4 \mathrm{aE}-01$ & pCVig & $u$ \\
\hline$Y=88$ & $-1.21 E-02+1-5.13 E-02$ & $1.14 E-01$ & $\mathrm{pClg}$ & $u$ \\
\hline
\end{tabular}

Data Package ID: GSS0210144-1 


\section{Gamma Spectroscopy Results}

\section{Method PAI 713R7}

\section{Sample Results}

Client Name: Bechtel Nevada

Client Project Name: CAU 262

Client Project Number: V1747
Page: 2 of 2

Reported on: Friday, November 08, 2002

$09: 11: 21$

Laboratory Name: Paragon Analytics, inc.

PAl Work Order: 0210144

Field ID:250512-WASTE-1
Lab ID:0210144-2

Sample Matrix: Sludge

Date Prepared: 29-0ct-02

Prep SOP: PAI $739 R 5$

Prep Batch: GS01754
Date Collected: 21-Oct-02

Date Analyzed: 29-0ct-02

Analytical SOP: PAI 713R7

Spectrum Code: 021141D07A
Final Aliquot: $347.1 \mathrm{~g}$

Report Basis: As Received

Count Time (min.) 30

Library: GAM-A-001บ

\begin{tabular}{|c|c|c|c|c|}
\hline Target Nuclide & Result $+1-2$ s TPU & MDC & $\begin{array}{c}\text { Reporting } \\
\text { Units }\end{array}$ & Lab Qualifier \\
\hline
\end{tabular}

\section{Comments:}

\section{Qvaliensfage:}

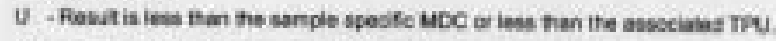

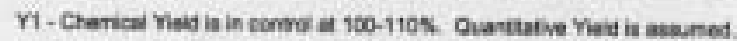

r2-Charical ned outside defaut ima.

IT - Rasit s less than flequesad MDC, oreater hen aanpla specks MOC.

30-9ectral quaby sreverts actarate duavitufion.

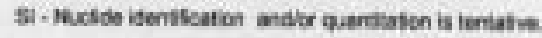

7)- Nudide idertficoson is temaine.

R- Meride has exceedec s hafhes.
Abbreiations:

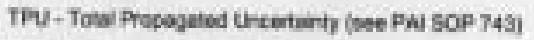

MDC - Minmum Oneciatie Concentration (see PAI 50P 709 ) 


\section{Analytical Report}

HONVIE LAGORTORY INC.

Client: BECHTEL-NEVADA V1898

LVL \#: 0302L786

W.O. \#: 60052-001-001-0001-00

Date Received: 02-20-2003

\section{DIESEL RANGE ORGANICS}

Three (3) water samples were collected on 02-18-2003.

The samples and their associated QC samples were extracted on 02-21-2003 and analyzed according to Lionville Laboratory OPs on 02-25-2003. The extraction procedure was based on method 3520 and the extracts were analyzed based on method 8015B for Diesel Range Petroleum Hydrocarbons.

1. All results presented in this report are derived from samples that met LvLI's sample acceptance policy.

2. The required holding time for extraction and analysis has been met.

3. The method blank was below the reporting limits for all target compounds.

4. All surrogate recoveries were within acceptance criteria.

5. The blank spike recovery was within acceptance criteria.

6. The matrix spike recoveries were within EPA QC limits.

7. All initial calibrations associated with this data set were within acceptance criteria.

8. All continuing calibration standards analyzed prior to sample extracts were within acceptance criteria.

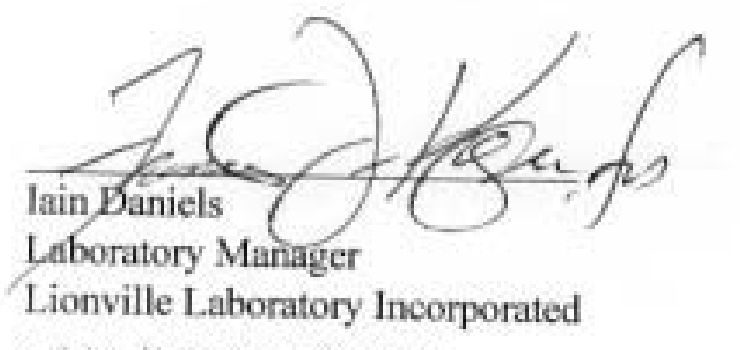

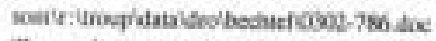

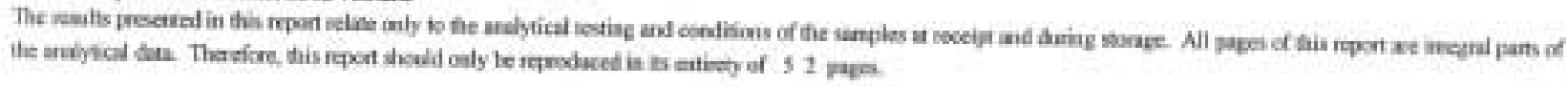




\section{GLOSSARY OF DIESEL RANGE ORGANICS DATA}

\section{DATA QUALIFIERS}

$\mathbf{U}=$ Indicates that the compound was analyzed for but not detected. The minimum detection limit for the sample (not the method detection limit) is reported with the $\mathrm{U}$ (e.g., 10U).

J = Indicates an estimated value. This flag is used in cases where a target analyte is detected at a level less than the lower quantification level. If the limit of quantification is $10 \mathrm{ug} / \mathrm{L}$ and a concentration of $3 \mathrm{ug} / \mathrm{L}$ is calculated, it is reported as $3 J$.

B = This flag is used when the analyte is found in the associated blank as well as in the sample. It indicates possible/probable blank contamination.

$\mathbf{E}=$ Indicates that the compound was detected beyond the calibration range and was subsequently analyzed at a dilution.

I $=$ Interference.

\section{ABBREVIATIONS}

BS = Indicates blank spike in which reagent grade water is spiked with the CLP matrix spiking solutions and carried through all the steps in the method. Spike recoveries are reported.

BSD $=$ Indicates blank spike duplicate.

MS = Indicates matrix spike.

MSD = Indicates matrix spike duplicate.

DL = Indicates that recoveries were not obtained because the extract had to be diluted for analysis.

NA $=$ Not Applicable.

DF = Dilution Factor.

NR = Not Required.

SP $\quad=$ Indicates Spiked Compound. 


\section{GLOSSARY OF DIESEL RANGE ORGANICS DATA}

D = This flag identifies all compounds identified in an analysis at a secondary dilution factor.

C = This flag applies to a compound that has been confirmed by GCMS. 


\section{Bechtel Nevada}

\section{DATA VALIDATION COVER SHEET}

\section{Section I}

MEF Number: CA4 262 SDG V1898 Sample Request Number:

Contract Laboratory: Lianville Lob Ine. Organization:

BN ER

Validation Procedure/nstruction, including revision number:

Analysis Requested (check all that apply):

$\square$ Volatile Organics

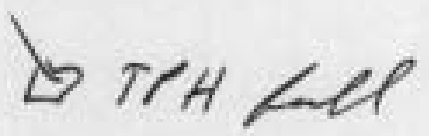

Semi Volatile Organics

$\square$ Inorganics

$\square$ Organochlorine Pesticides/Polychlorinated Biphenals (PCBs)

$\square$ Radiochemistry

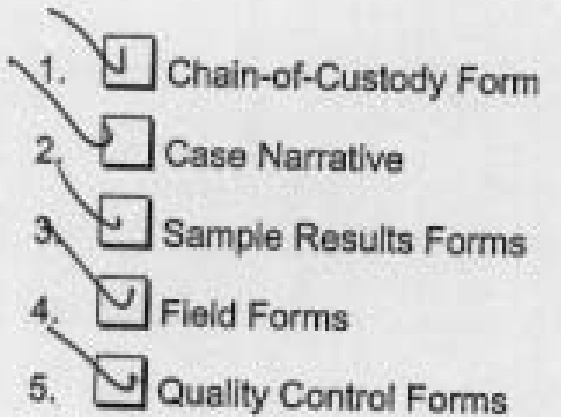

\section{Section II}

Identify any samples that are missing:

Comments/Problems: (include information about requests for further information submitted to the contract laboratory and agreed upon date of resolution and contract laboratory point of contact):

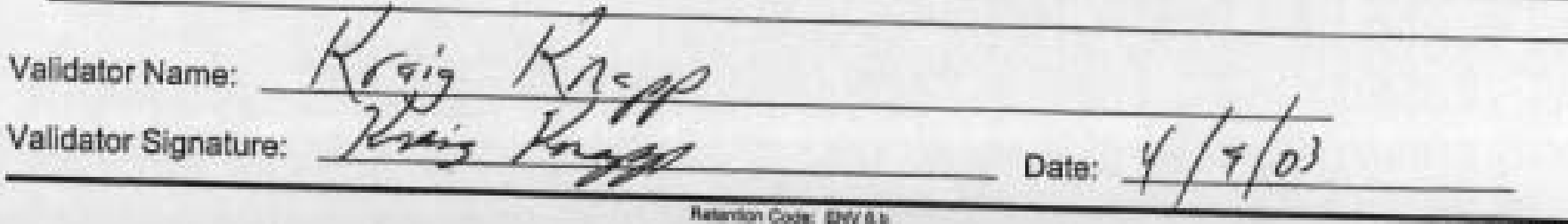




\section{DATA VALIDATION CHECKLIST}

\section{Analyses Reviewed: $T P H(G R O)$}

Date: $4 / 9 / 03$

\section{DATA REVIEW}

1. Requested analyses were performed on all samples.

2. Samples were extracted, prepared, and analyzed within holding times.

3. Cooler temperature was recorded upon receipt.

4. Proper preservation / $\mathrm{pH}$ was used for each matrix and analysis.

5. The laboratory sample identification corresponds to the client sample identification.

6. Background checks were performed at the proper frequency and were acceptable.

7. efficiency checks were performed at the proper frequency and were acceptable.

8. Method blanks were analyzed and were acceptable.

9. All MDAs were less than the RDLs.

10. LCSs were analyzed at the proper frequency and recoveries were acceptable.

11. MS were analyzed at the proper frequency and recoveries were acceptable.

12. Lab duplicates were analyzed the proper frequency and RPDs were acceptable.

13. QC batches correspond clearly with analytical batches.

14. Sample activity/concentration units are reported accurately.

15. Dilutions were properly noted and calculated.

16. Sample detection limits were properly adjusted for dilutions.

17. Detection limits meet project requirements.
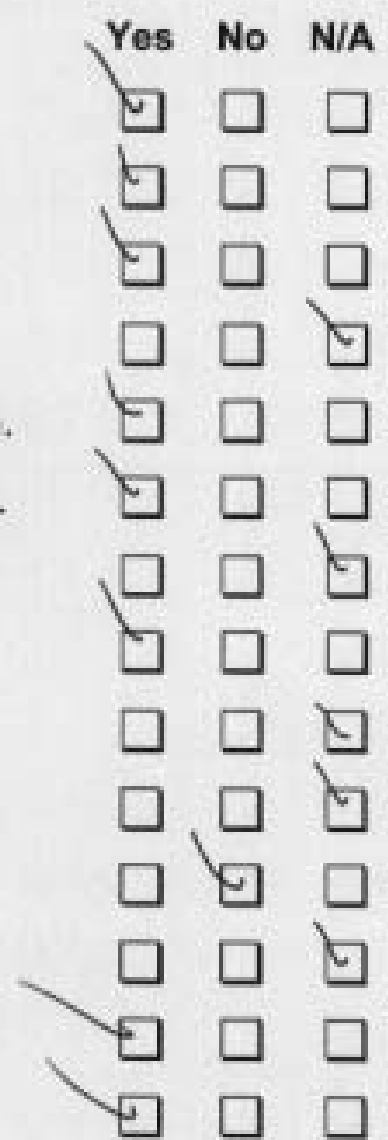

\section{QUALIFIERS}

\section{QC Result}

Preparation Blank:

Leb-Control Sample:

Matrix Spike:
Qualifier

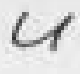

Duplicate Sample:

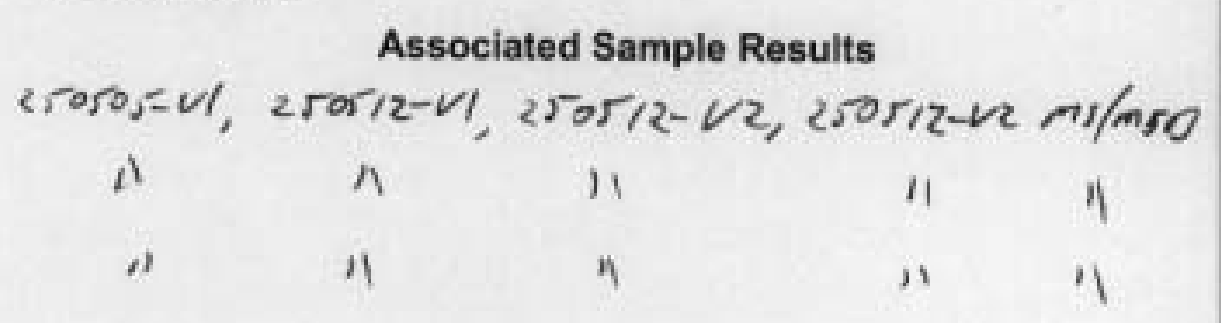

Associated Sample Results

Validator Name: $/$ reig Knsp

Signature:

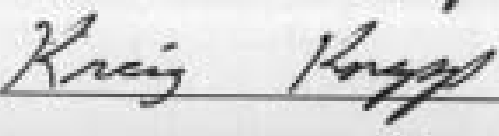

Date:

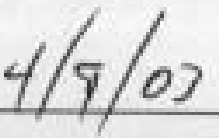




\section{DATA VALIDATION CHECKLIST}

Analyses Reviewed: TPH (ORO)

Date: $4 / 9 / 03$

\section{DATA REVIEW}

1. Requested analyses were performed on all samples.

2. Samples were extracted, prepared, and analyzed within holding times.

3. Cooler temperature was recorded upon receipt.

4. Proper preservation / $\mathrm{pH}$ was used for each matrix and analysis.

5. The laboratory sample identification corresponds to the client sample identification.

6. Background checks were performed at the proper frequency and were acceptable.

7. efficiency checks were performed at the proper frequency and were acceptable.

8. Method blanks were analyzed and were acceptable.

9. All MDAs were less than the RDLs.

10. LCSs were analyzed at the proper frequency and recoveries were acceptable.

11. MS were analyzed at the proper frequency and recoveries were acceptable.

12. Lab duplicates were analyzed the proper frequency and RPDs were acceptable.

13. QC batches correspond clearly with analytical batches.

14. Sample activity/concentration units are reported accurately.

15. Dilutions were properly noted and calculated.

16. Sample detection limits were properly adjusted for dilutions.

17. Detection limits meet project requirements.

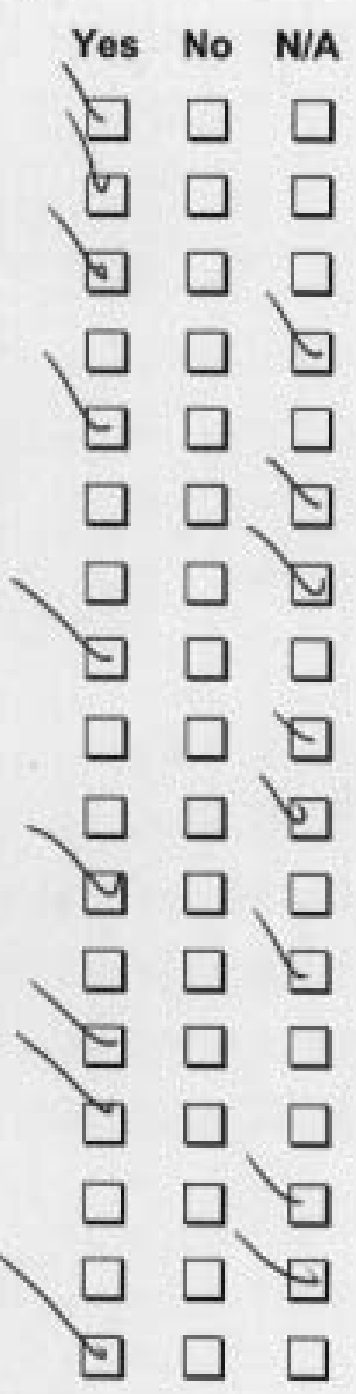

\section{QUALIFIERS}

\section{QC Result}

Preparation Blank:

Lab Gentrol-Sample:
Qualifier

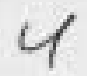

xre
Associated Sample Results

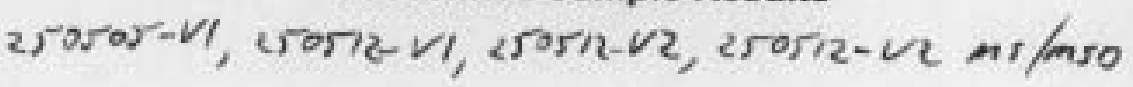

Matrix Spike:

$\leadsto$

II

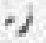

Dupticate Sample:

validator Name: Kroig

Signature:

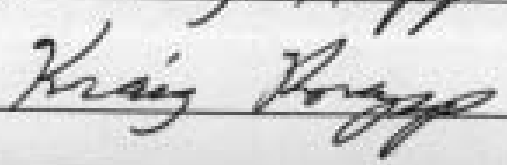

Date:

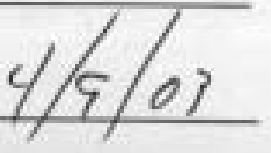




\section{Bechtel Nevada}

\section{DATA CONFIDENCE STATEMENT}

\section{J0G 11898 \\ MEF Number: $\mathrm{CAC} 262$ Analyses:

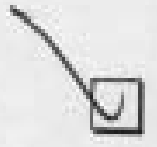 \\ Field and QAVC sample data have been generated in accordance with method requirements and within quality control. Requirements of the SOW have been met. \\ Comments: $\cap R O$}

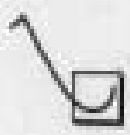

QAVC problems were encountered during analysis of the samples. Usability is not
affected, data are acceptable.

Comments: $\rightarrow$ PO

Significant QAVC problems were encountered during analysis of the samples.

Data for the following samples is rejected:

Summary:
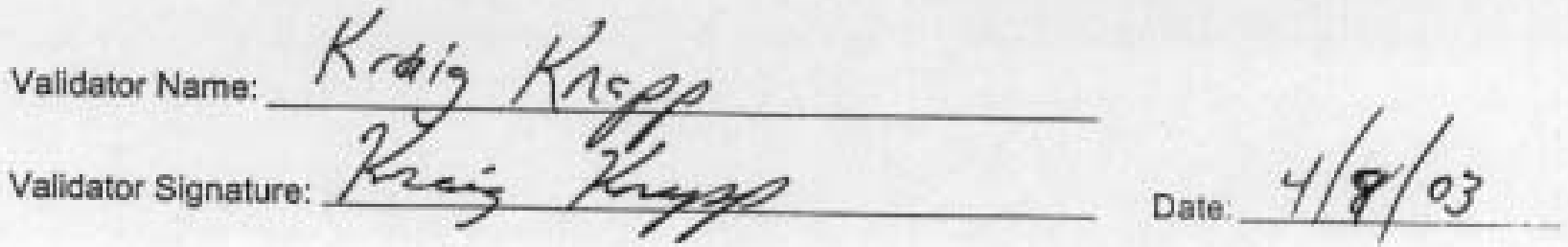
TIER I REVIEW

GENERAL INFORMATION

1. Project Name and/or Sample Delivery Group (SDG): $V / 898$

2. Date Samples taken:

$2 / 18 / 03$

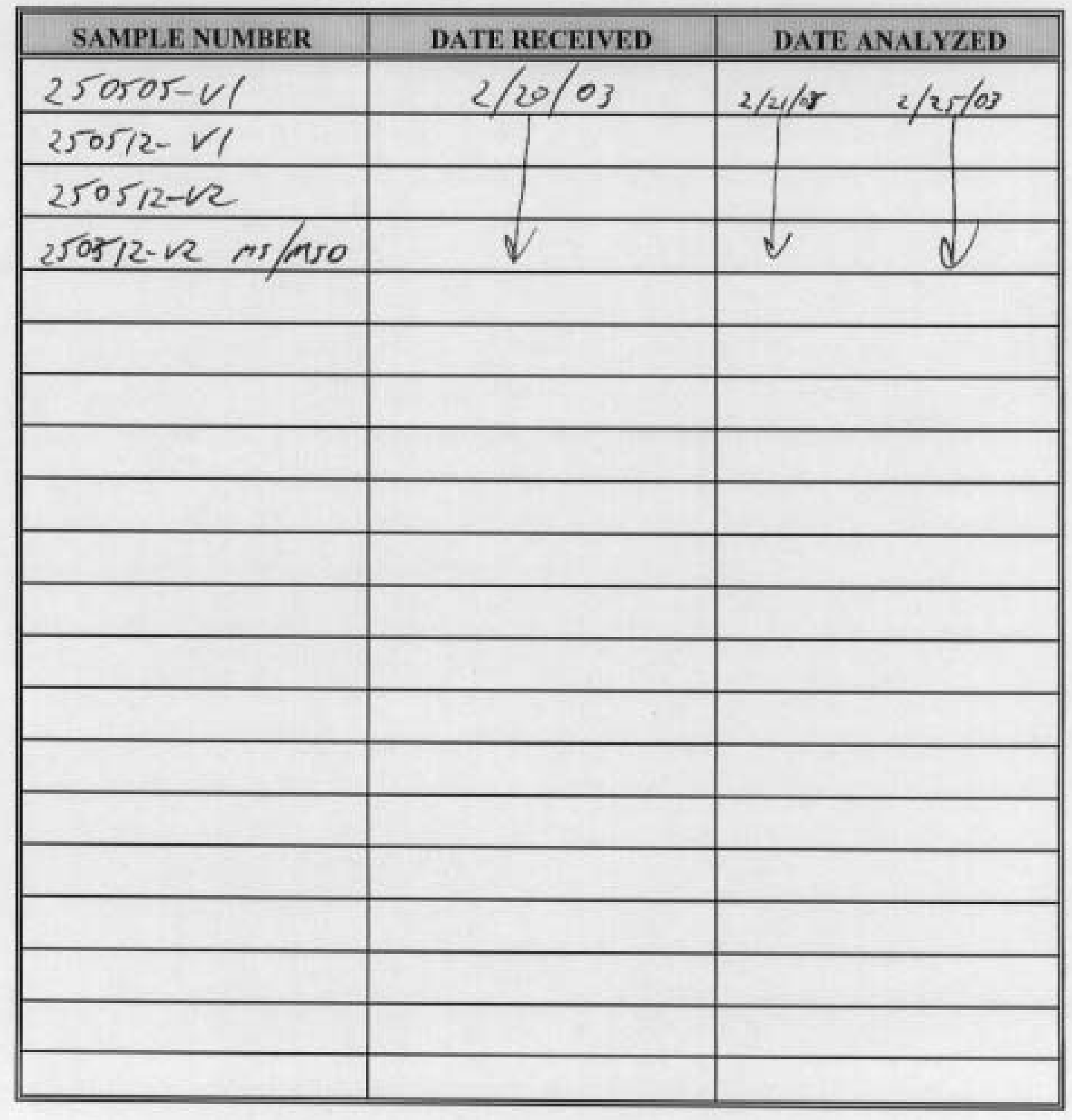


3. Date of Review: $4 / 9 / 03$

4. Chain of Custody (COC):

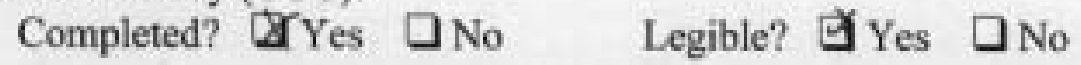

5 . Is a cover letter/case narrative attached? $\square$ Yes $\square$ No

If 'yes,' has it been reviewed for significant problems? $\triangle$ Yes $\square$ No $\square$ NA

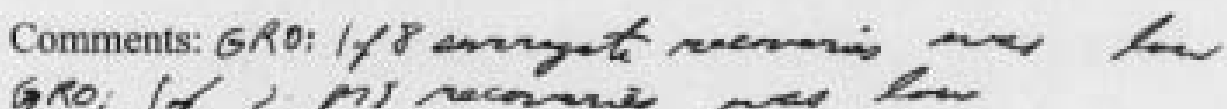

6. Analyses requested (Attach COC, Sample Request Form, and lab data packet to this review):

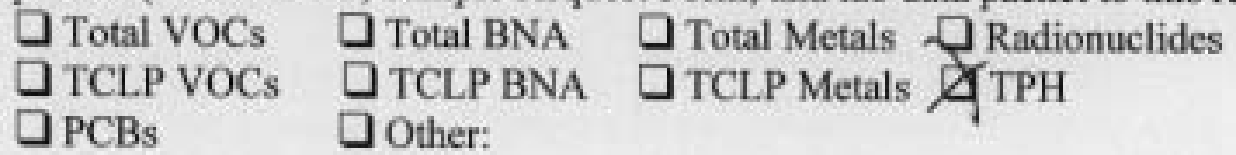

7. Were all requested analyses performed on all samples? $\searrow$ Yes $\square$ No

8. Temperature on cooler: $4{ }^{\circ} \mathrm{C}$ (parameters: $4^{\circ} \mathrm{C} \pm 2^{\circ}$ ) or $\square$ NA

10. Refer to Table 1. Was the proper preservation used? $\square$ Yes $\square$ No If 'no,' then explain: 
TOTAL PETROLEUM HYDROCARBONS (TPH)

\begin{tabular}{|c|c|c|c|c|c|}
\hline PARAMETER & $\begin{array}{l}\text { EXTRACTION } \\
\text { HOLD TIME } \\
\end{array}$ & $\begin{array}{c}\text { ANALYSIS } \\
\text { HOLD TIME } \\
\end{array}$ & $\begin{array}{l}\text { DAYS } \\
\text { HELD } \\
\end{array}$ & $\begin{array}{c}\text { PASS } \\
\text { Y/N } \\
\end{array}$ & $\begin{array}{c}\text { SAMPLES } \\
\text { NOT PASSING }\end{array}$ \\
\hline $\begin{array}{l}\text { Total TPH } \\
\text { EPA Method } \\
8015 \mathrm{M} \text { or } \\
8015 \mathrm{~B}\end{array}$ & $\begin{array}{l}\text { Liquids }-14 \text { days } \\
\text { Soils }-14 \text { days } \\
\text { Oil }-14 \text { days }\end{array}$ & NA & & & \\
\hline $\begin{array}{l}\text { Total TPH } \\
\text { EPA Method } \\
8015 \mathrm{M} \text { or } \\
8015 \mathrm{~B}\end{array}$ & NA & $\begin{array}{l}\text { Liquids - } 40 \\
\text { days } \\
\text { Soils - } 40 \text { days } \\
\text { Oil - } 40 \text { days }\end{array}$ & & & \\
\hline Comments: & & & & & \\
\hline
\end{tabular}

Was TPH digestion done within the hold time limit? $\square$ Yes $\square$ No

Were analyses run within the hold time limit? $\square$ Yes $\square$ No

A. TPH reported as: $\square \mathrm{mg} / \mathrm{Kg}$ or $\square \mathrm{ug} / \mathrm{Kg}$ Other: $\mu \mathrm{g} / \mathrm{C}$

B. Hits above detection level found in LB, RBS, FB, RB, or other QA samples? $\square$ Yes $\square$ No If 'yes,' explain:

C. Did laboratory report indicate any problems? $\square$ Yes $\square$ No If 'yes,' explain:

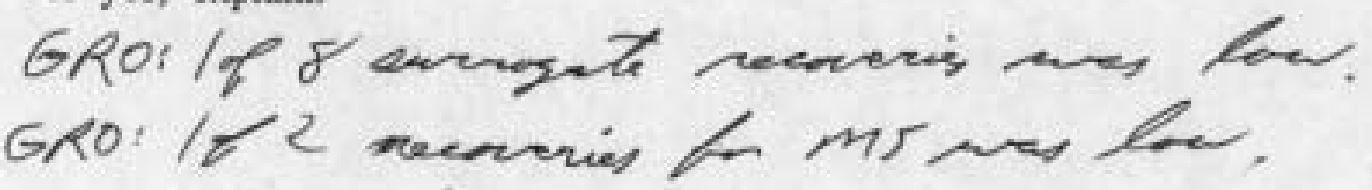




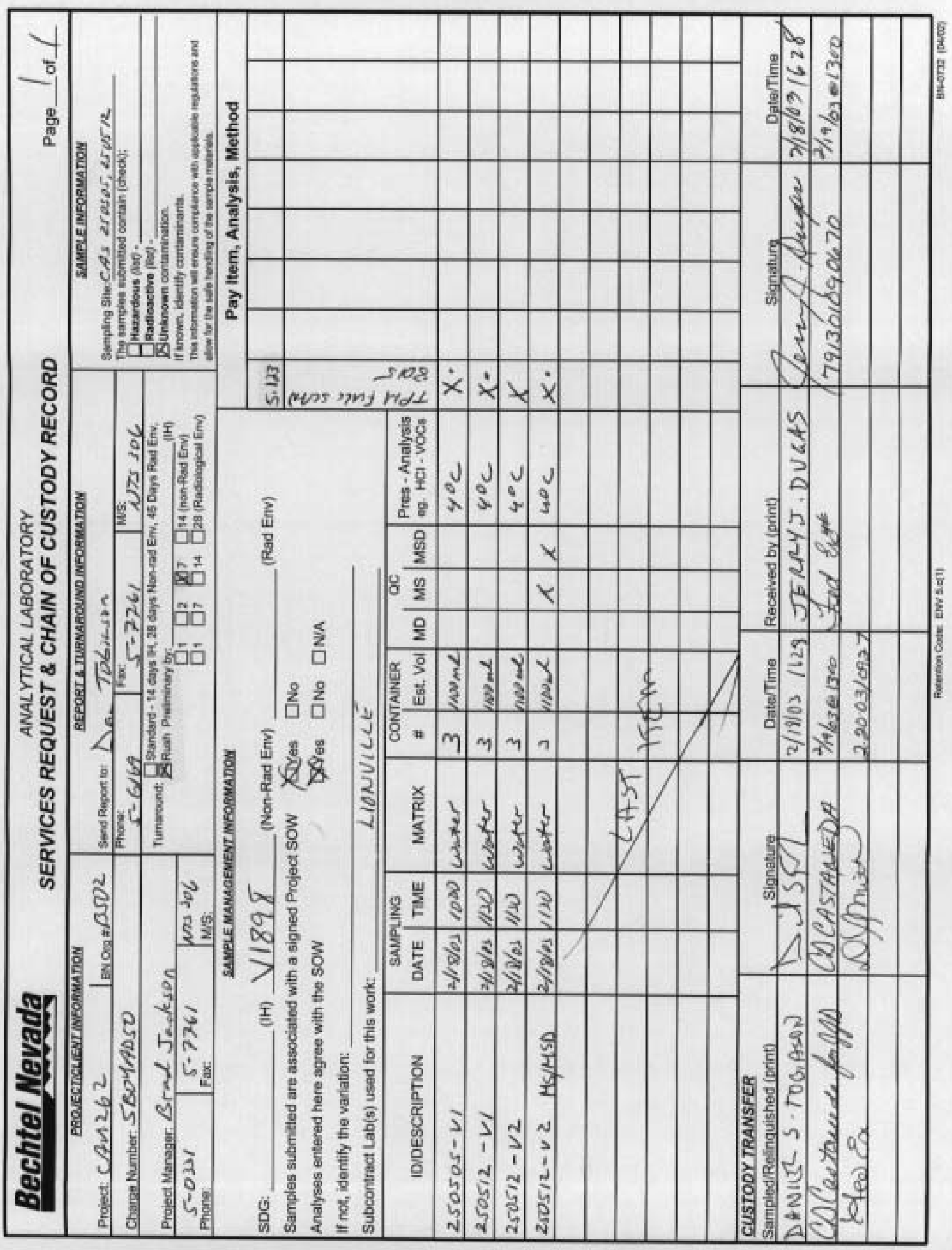


Lab Name: Lionville Labs. Inc, Work Order: 60052001001

Client: BRCHTEL NBVADA V1898

Matrix:

WATBR

Lab Sample ID:

Sample wt/vol:

$1000 \quad(\mathrm{~g} / \mathrm{mL}) \mathrm{VL}$

Level: $\quad(10 \mathrm{w} / \mathrm{med}\}$ LOW

\%oisture: not dec.

Columin: (pack/cap) CAP

Lab Pile ID:

COMPOUND

BLKLLACHJ

Date Received: $02 / 20 / 03$

Date Analyzed: $\underline{02 / 25 / 03}$

Dilution Factor: 1.00

CONCENTRATION UNITS: (ug/L or ug/ $\mathrm{Kg}$ ) ug/L

\begin{tabular}{|c|c|}
\hline 68334-30-5 ....-Diesel Range Organica & 340 \\
\hline $00-00=0000 \ldots-\ldots$ Motor 011 & 590 \\
\hline
\end{tabular}

12/88 Rev. 
ORGANICS ANALYSIS SHBBT

Lab Name: Lionville Labs. Ine, Work Ordert 60052001001
CLIENT SAMPLE NO.

250512-V1

Client: BECHTEL NEVADA V1B98

Matrix:

WATER

Lab Sample ID:

$03021786-002$

Sample wt/vol:

$1000(\mathrm{~g} / \mathrm{mL}) \mathrm{ML}$

Lab File ID:

BLKLACHN

Level: (low/med) LOW

Date Received: $02 / 20 / 03$

4 Moisture: not dec.

Date Analyzed: $22 / 25 / 03$

Column: (pack/cap) CAP.

Dilution Factor: 1.00

CONCENTRATION UNITS:

CAS NO.

COMPOLND

(ug/L or $u g / K g$ ) ug/L.

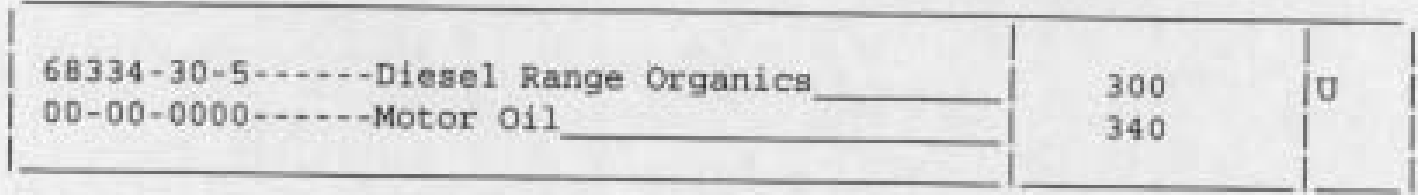

12/8a Rev, 
ORGANICS ANALYSIS SHBET

Lab Name: Lionville Labs. Inc, Work Order: 60052001001

Client: BBCHTBL NEVADA V1B98

Matrix:

WATRR

Lab Sample ID: 0302L786-003

Sample $w t / \mathrm{vol}:$

$1000(\mathrm{~g} / \mathrm{mL}) \mathrm{ML}$

Level: [low/med) LOW

Lab pile ID:

Date Received: $\underline{02 / 20 / 03}$

* Molsture: not dec.

Date Analyzed: $\underline{02 / 25 / 03}$

Column: (pack/cap) CAP

CAS No.

COMPOUND
Dilution Factor: 1,00

CONCENTRATION UNITS:

(ug/L or $u g / \mathrm{kg}$ ) $\mu \mathrm{g} / \mathrm{L}$.

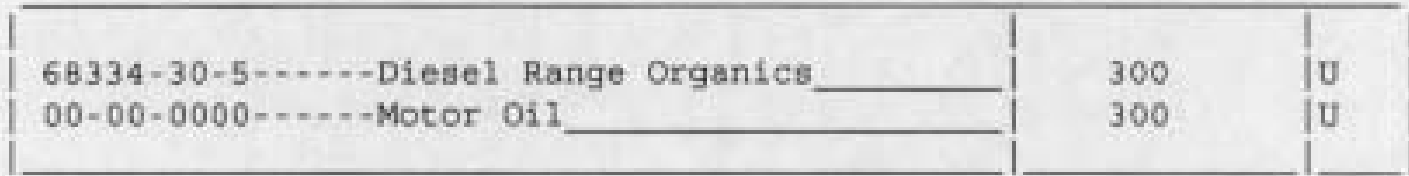

12/88 Rev. 


\section{Analytical Report}

MONVIIE LARORATOMY INC

Client: BECHTEL-NEVADA V1898

LVL \#: 0302L 786

W.O. \#: 60052-001-001-0001-00

Date Received: 02-20-2003

\section{GRO}

Three (3) water samples were collected on 02-18-2003.

The samples and their associated QC samples were analyzed according to Lionville Laboratory $\mathrm{OP}_{\mathrm{s}}$ based on SW-846 method 8015 for Gasoline range organics (GRO) on 02-25-2003.

The following is a summary of the QC results accompanying these sample results and a description of any problems encountered during their analyses:

1. All results presented in this report are derived from samples that met LVLI's sample acceptance policy.

2. Samples were analyzed within required holding time.

3. The method blank was below the reporting limits for all target compounds.

4. One (1) of eight (8) surrogate recoveries was outside acceptance criteria. A copy of the Sample Discrepancy Report (SDR) has been enclosed.

5. The blank spike recoveries were within acceptance criteria.

6. One (1) of two (2) matrix spike recoveries was outside acceptance criteria. A copy of the Sample Discrepancy Report (SDR) has been enclosed.

7. All initial calibrations associated with this data set were within acceptance criteria.

8. All continuing calibration standards analyzed prior to sample extracts were within acceptance criteria.
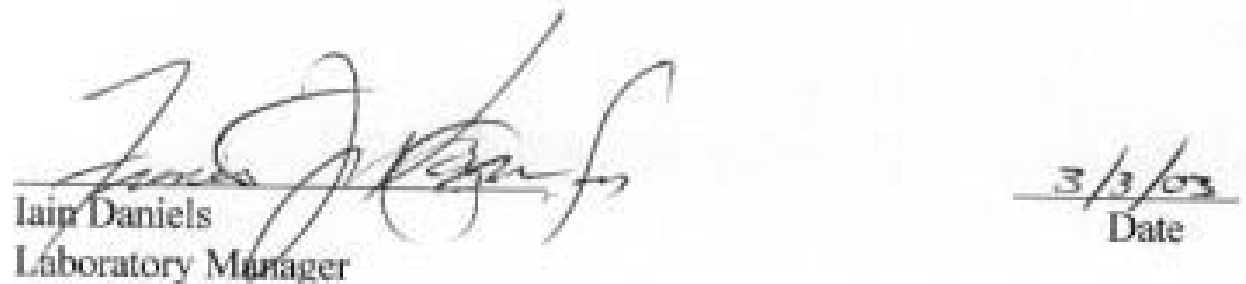

Lionville Laboratory Incorporated

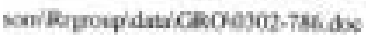

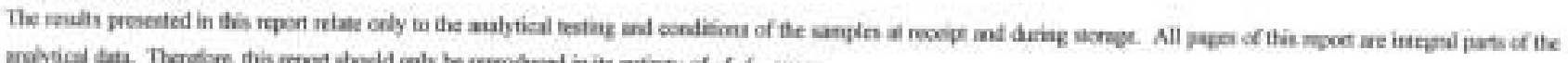

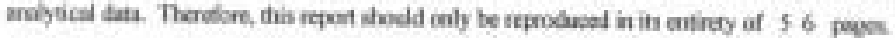




\section{Lionville Laboratory Sample Discrepancy Report (SDR)}

SDR\#:0360047

Initiator: John Lewh.

Date:

Client:
$2 / 2+100$

Beshrel
Batch: $0302 L 786$

Samples: $m s D$

Method: swsagmcanuicipl
Parameter:

Matrix:

Prep Batch:

\section{Reason for SDR}
a. COC Discrepancy
Tech Profile Error
- Transcription Error
Client Request
Wrong Test Code
Sampler Error on C-O-C

b. General Discrepancy Trar Missing Sample/Extract

- Hold Time Exceeded

_ Improper Bottle Type

_Insufficient Sample

_ Not Amenable to Analysis _-Preservation Wrong _ Received Past Hold

Note": Verfied by [Log-In] or [Prep Group] (circle) .. signatureldate:

c. Problem (Include all relevant specific results; attach data if necessary)

mso ne recasienes.

\section{Known or Probable Causes(s)}

cractied Paretuhe
3. Discussion and Proposed Action
Other Description:
_Re-log
_Entire Batch

$$
\begin{aligned}
& \text { Nowte. ms in contrul } \\
& \text { erecision shuen by BS \& } 359
\end{aligned}
$$
Following Samples:
- $\overline{R e}$-leach
- Re-extract
- Re-digest
- Revise EDD
- Change Test Code to
_ Place On/Take Off Hold (circle)

4. Project Manager Instructions ... signatureidate:

Concur with Proposed Action
- Disagree with Proposed Action; See Instruction

$y / 2$ 2/26/os

Anclude in Case Narrative

Client Contacted:

- Date/Person

- Add

- Cancel

5. Final Action. signatureitate:

Verified re-flog][leach][extract][digtst][analysis] (circle)

$Z$ Included in Case Narrative

- Hard Copy COC Revised

- Electronic COC Revised

- EDD Corrections Completed

\begin{tabular}{|c|c|c|c|}
\hline Route & Distribution of Completed SDR & Route & Distribution of Completed SDR \\
\hline & X Initiator & & Metals: Beegle \\
\hline - & X Lab General Manager. M. Taylor & - & - Inorganic: Perrone \\
\hline & X Project Mgr: Stone/Johnson/Haslett & 二 & _ GCILC: Kiger \\
\hline & X Technical Mgr. Wesson/Daniels & - & MS: Rychlak/Layman \\
\hline & XQA (file) & - & _Log-in: Melnic \\
\hline - & - Data Management: Feidman & - & Admin: Soos \\
\hline - & __ Sample Prep: Beegle/Kiger & - & _Other: \\
\hline
\end{tabular}

When Final Action has been recorded, forward original to QA Specialist for distribution and filing. 


\section{GLOSSARY OF GASOLINE RANGE ORGANICS DATA}

\section{DATA QUALIFIERS}

$\mathbf{U}=$ Indicates that the compound was analyzed for but not detected. The minimum detection limit for the sample (not the method detection limit) is reported with the $\mathrm{U}$ (e.g., 10U).

$\mathbf{J}=$ Indicates an estimated value. This flag is used in cases where a target analyte is detected at a level less than the lower quantification level. If the limit of quantification is $10 \mathrm{ug} / \mathrm{L}$ and a concentration of $3 \mathrm{ug} / \mathrm{L}$ is calculated, it is reported as $3 \mathrm{~J}$.

B = This flag is used when the analyte is found in the associated blank as well as in the sample. It indicates possible/probable blank contamination.

$\mathbf{E}=$ Indicates that the compound was detected beyond the calibration range and was subsequently analyzed at a dilution.

$\mathbf{I}=$ Interference.

\section{ABBREVIATIONS}

BS = Indicates blank spike in which reagent grade water is spiked with the CLP matrix spiking solutions and carried through all the steps in the method. Spike recoveries are reported.

BSD $=$ Indicates blank spike duplicate.

MS = Indicates matrix spike.

MSD $=$ Indicates matrix spike duplicate.

DL = Indicates that recoveries were not obtained because the extract had to be diluted for analysis.

NA $=$ Not Applicable.

DF $=$ Dilution Factor.

NR $=$ Not Required.

SP $=$ Indicates Spiked Compound. 


\section{GLOSSARY OF GASOLINE RANGE ORGANICS DATA}
D = This flag identifies all compounds identified in an analysis at a secondary dilution factor.
C = This flag applies to a compound that has been confirmed by GCMS.


GC VOLATILES SHEET

Lab Name: Lionville Labs. Inc, Work Order: 60052001001 I.

Client $t$ BECHTRL NBVADA V1898

Matrix:

Sample wt/vol:

WATER

$\underline{5.00}(\mathrm{~g} / \mathrm{mL})$ ML

Leve 1: (low/med) LoW

\& Moisture: not dec.

Column: (pack/cap) CAP

CAS No.

COMPOUND
Lab Sample IDt 0302L786-001

Lab File ID:

Date Received; $02 / 20 / 03$

Date Analyzed: $\underline{02 / 25 / 03}$

Dilution Factor: 1.00

CONCENTRATION UNITS: (ug/L or ug/Kg) WG/L

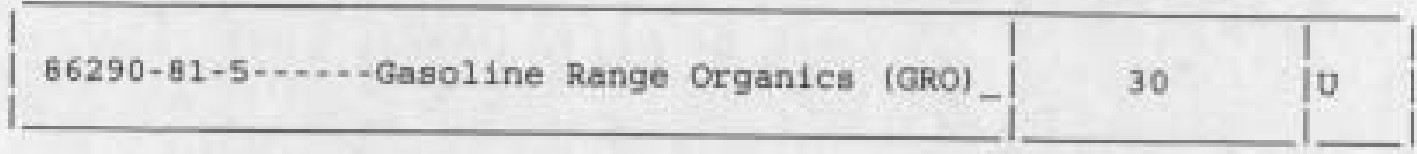

12/88 Rev. 
Lab Name t Lionvidze Labs. Inc. Work Order: 60052001001

Client : BBCHTBL NBVADA V2 998

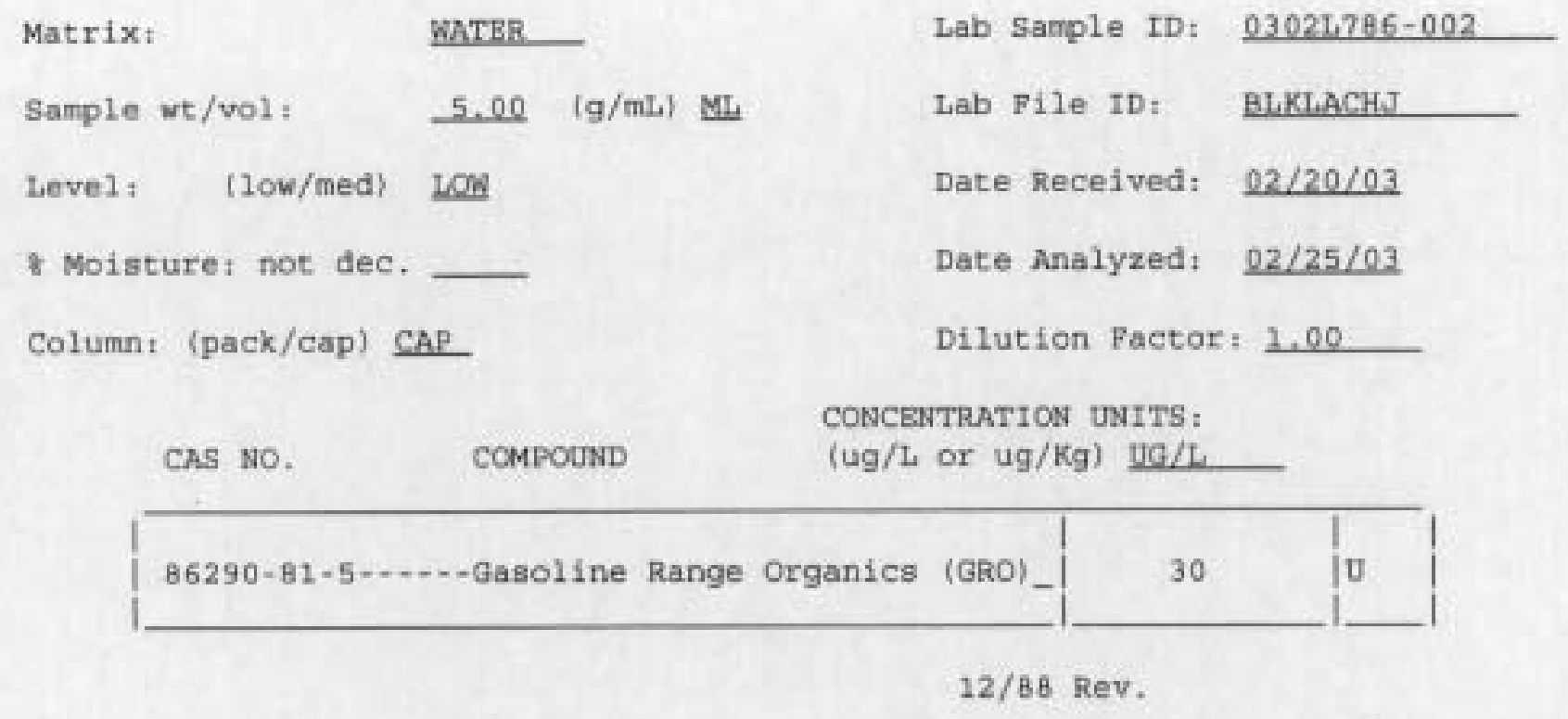


GC VOLATILES SHEET

Lab Name: Lionvidle Labs. Inc. Work Order: 60052001001

Client: BECHTET, NBVADA V1898

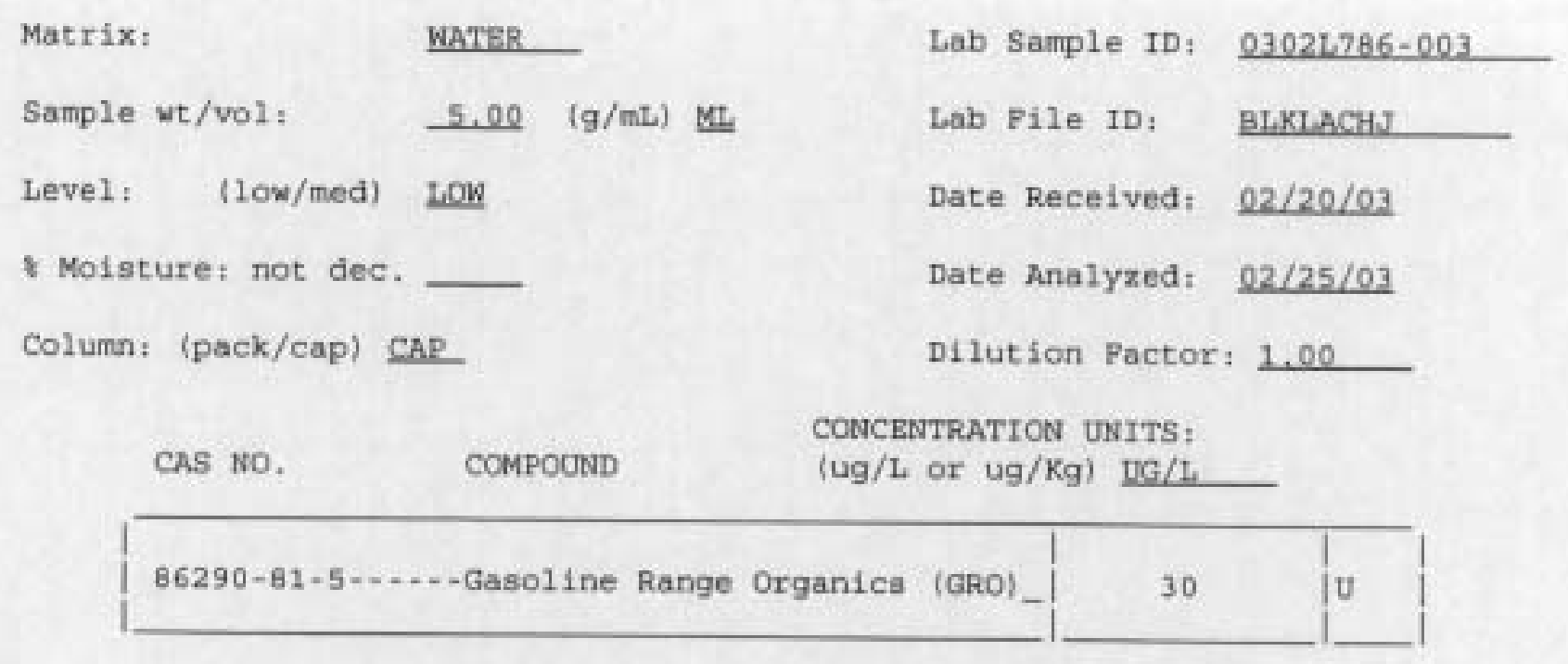

12/88 Rev. 


\section{$S C E A$ S. Conver Asecours}

February 27, 2003

Mr. Ted Redding

USDOE Zone 1

Bldg. 652, Room 2

M/S NTS 273

Mercury, NV 89023

Dear Mr. Redding:

On February 20, 2003, one water sample (SDG V1899) was received for analysis at the Sanford Cohen and Associates (SC\&A) Southeastern Environmental Laboratory. The chain-of-custody accompanying the sample requested that the sample results be reported within seven days of receipt. The samples were assigned Laboratory Report Identification Code 4024. Enclosed the Sample Data Package containing the results of the analyses for the sample.

If you have any questions please do not hesitate to call.

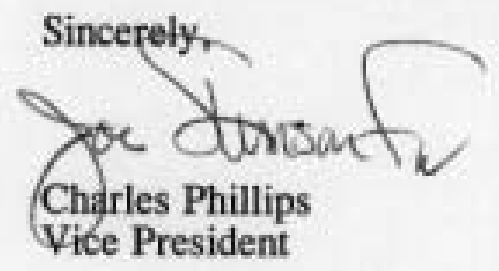




\title{
COVER PAGE
}

\author{
Sanford Cohen \& Associates \\ Southeastern Environmental Laboratory \\ 1000 Monticello Court \\ Montgomery, Alabama 36117 \\ Laboratory Code: SCA Contract Number: 30025 \\ Laboratory Report Identification Code: 4024 SDG: V1899
}

Sample Matrix: Water

\begin{tabular}{|l|l|}
\hline \multicolumn{1}{|c|}{ Site Sample Numbers } & \multicolumn{1}{|c|}{$\begin{array}{c}\text { Laboratory Sample } \\
\text { Number }\end{array}$} \\
\cline { 2 - 2 } & \multicolumn{1}{|c|}{ Gross Alpha/Beta } \\
\hline $250505-\mathrm{V} 1$ & NTS03-4024-01 \\
\hline Laboratory Control Sample (LC) & SCAQC-4024-LCl \\
\hline Duplicate (LD) & SCAQC-4024-LCl \\
\hline Preparation Blank (PB) & SCAQC-4024-PB \\
\hline
\end{tabular}

Comments: There were no problems encountered during sample receiving.

"I certify that this sample data package is in compliance with SOW requirements, both technically and for completeness, other than the conditions detailed above. Release of the data contained in this hard-copy sample data package and the Manager or the Manager's designee, as verified by the following signature.
Mas been authorized by the laboratory

\section{Signaxre \\ Name}

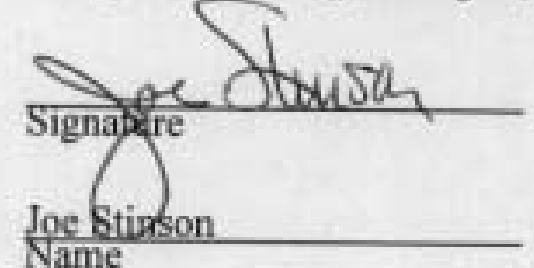

Laboratory Manager

Title
2/27/03

Date 


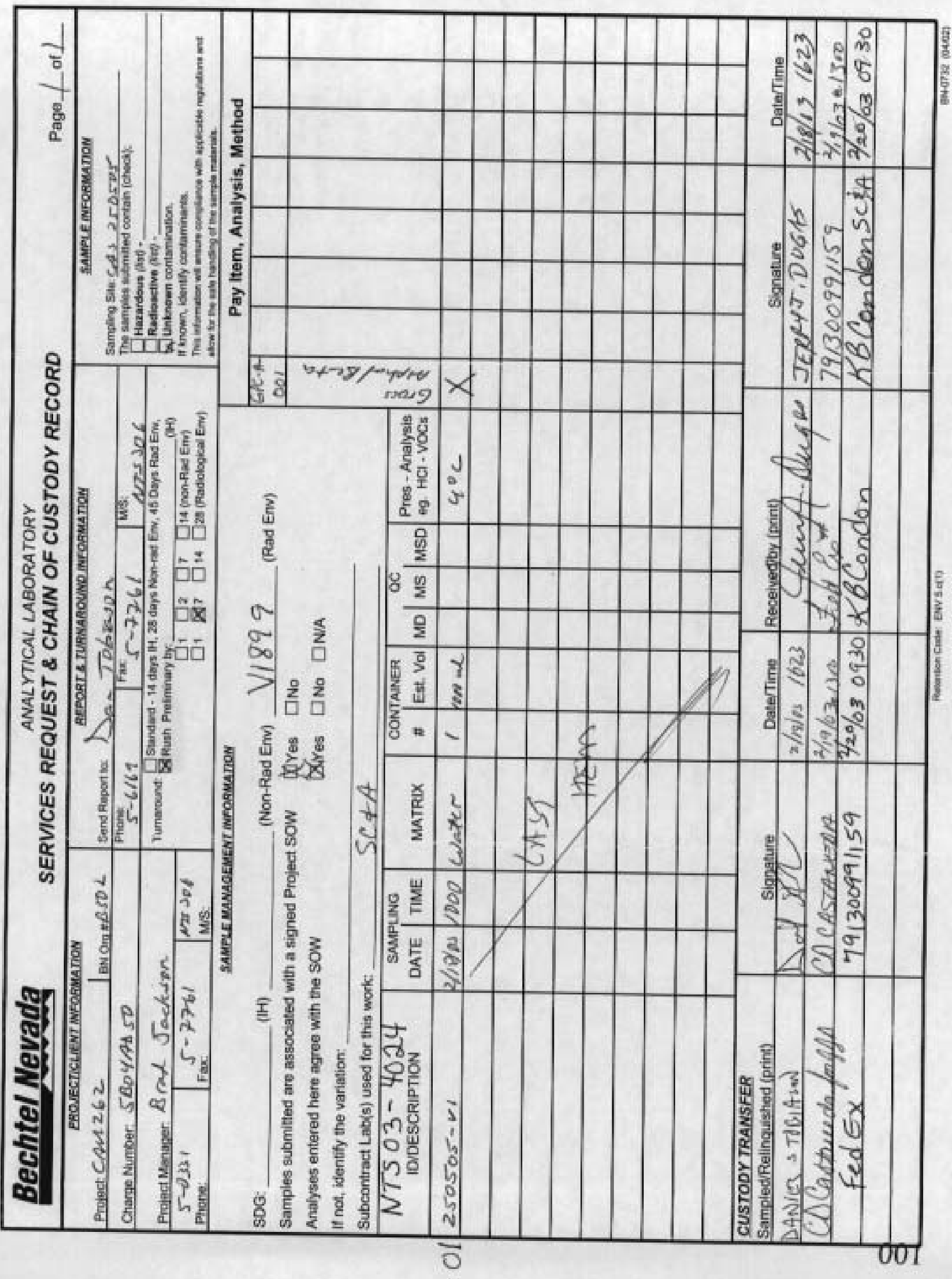




\section{CASE NARRATIVE \\ SDG V1899 \\ Laboratory Report Identification Number: 4024}

February 27, 2003

\section{Introduction}

On February 20, 2003, one water sample was received for analysis at the Sanford Cohen and Associates (SC\&A) Southeastern Environmental Laboratory, located in Montgomery, Alabama. The chain-of-custody accompanying the sample requested that it be reported within seven days. The samples were analyzed in accordance with the Bechtel Nevada Services Subcontract Task Order Agreement Form, Exhibit B, Statement of Work and Specifications, Rev 1, 1/23/01.

\section{Analytical Methodology}

The radioanalytical results reported for the sample include the site and laboratory sample identification numbers, collection date, method of analysis, and the quality control samples that were analyzed concurrently. The Samples were analyzed in accordance with the following methods.

\begin{tabular}{||l|l|l|l||}
\hline Radionuclide & \multicolumn{1}{|c|}{$\begin{array}{c}\text { Method } \\
\text { Number }\end{array}$} & \multicolumn{1}{|c|}{$\begin{array}{c}\text { Method } \\
\text { Name }\end{array}$} & $\begin{array}{c}\text { Counting } \\
\text { Method }\end{array}$ \\
\hline \hline Gross Alpha & EPA 900.0 & Gross Alpha Radioactivity & $\begin{array}{l}\text { Gas Proportional } \\
\text { Counting }\end{array}$ \\
\hline Gross Beta & EPA 900.0 & Gross Beta Radioactivity & $\begin{array}{l}\text { Gas Proportional } \\
\text { Counting }\end{array}$ \\
\hline
\end{tabular}

\section{Analytical Results}

\section{Deficiencies}

None.

Matrix Interferences

There were no indications of matrix interference.

Dilutions

No dilutions were required.

\section{Detection Limits}

The required detection limits (RDL) were met for all analyses.

Reanalysis

There were no reanalyses. 


\section{Deviations from Protocols}

There were no deviations from the written protocols and analytical methods,

Contacts with the CTR There were no contacts with the contract technical representative (CTR) regarding these
samples.

\section{Quality Control}

Site Samples Used for Quality Control Samples: Gross Alpha, Gross Beta

\begin{tabular}{|c|c|c|}
\hline Site Sample Number & Laboratory Sample Number & $\begin{array}{c}\text { Type of Quality Control Analysis } \\
\text { Sample }\end{array}$ \\
\hline Laboratory Type II Water & SCAQC-4024-LCl & Laboratory Control Sample \\
\hline $250505-\mathrm{VI}$ & SCAQC-4024-LDI & Laboratory Duplicate Sample \\
\hline Preparation Blank & SCAOC-4024-PB & Preparation Blank \\
\hline
\end{tabular}

The analytical results of all quality control samples met the acceptance criteria specified in the sow.

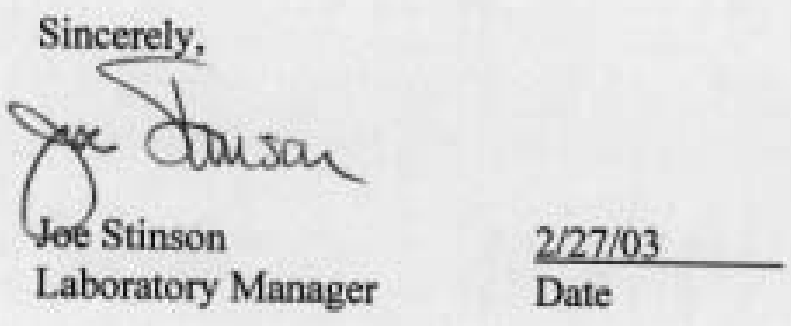




\section{Sanford Cohen \& Associates \\ Southeastern Environmental Laboratory \\ Radioanalytical Results}

Report Identifcation Number: V1B99

\begin{tabular}{|c|c|c|c|c|c|c|}
\hline $\begin{array}{l}\text { Project Name: } \\
\text { Site Sample ID; } \\
\text { Other Sample ID: }\end{array}$ & $\begin{array}{l}\text { Bechtel Nevada } \\
250505-V_{1}\end{array}$ & Chain-of-Cu & $\begin{array}{l}\text { Collection Date: } 21 \\
\text { Batch Number; } 40\end{array}$ & $\frac{1182003 \cdot 10: 00-00 \mathrm{~B}}{1024}$ & $\begin{array}{l}\text { Date Received: } \\
\text { Laboratory Code: }\end{array}$ & $\begin{array}{l}21202003 \\
\text { SCA }\end{array}$ \\
\hline Mathed Number & Badienuclide & $\begin{array}{l}\text { Laboratory } \\
\text { Sample ID } \\
\end{array}$ & $\begin{array}{l}\text { Activity } \\
\text { (ocin) }\end{array}$ & $\begin{array}{l}2 \text { a TPU } \\
\text { (eCl4) }\end{array}$ & $\begin{array}{l}\text { Total Error } \\
\text { (oCiL) } \\
\end{array}$ & $\begin{array}{c}\text { MOA } \\
\text { (pCind) } \\
\end{array}$ \\
\hline EPA 900.0 & ALPHA & NTS03-4024-01 & 3.30 & 2.71 & 3.17 & 3.78 \\
\hline EPA 900.0 & BETA & NTSO3-4024-01 & 5.42 & 1.45 & 2.18 & 1.50 \\
\hline
\end{tabular}

\begin{tabular}{|c|c|c|c|c|}
\hline \multicolumn{5}{|c|}{ Quality Control Samples } \\
\hline Radionuclide & Laberatory Centrel (LC) & Laberatecy Duplicale (LD] & Matrix Soke.MSI & Preparetien Blank (PB) \\
\hline Alpha & SCAOC-4024-LC1 & SCAQC-4024-LD1 & & SCAQC-4024-PB \\
\hline Beta & SCAQC-4024-LC1 & SCACC-4024-LD1 & & SCAQC-4024-PB \\
\hline
\end{tabular}


225 Commerce Drive * Fort Collins, CO 80524 • (800) 443-1511 • (970) 490-1511 • FAX (970) 490-1522

February 10,2003

Mr. Ted Redding

Bechtel Nevada

US DOE Zone 1, BIdg 652, Rm 2, M/S NTS273

Mercury NV 89023

RE: Paragon Workorder: 03-01-130

Client Project Name: CAU 262

Client Project Number: V1860

Dear Mr. Redding:

Two solid samples were received from Bechtel Nevada on January 28, 2003. The samples were scheduled for Gross Alpha/Beta (pages 1-147) and Gamma Spectroscopy (pages 1122) analyses. The results for these analyses are contained in the enclosed reports.

Thank you for your confidence in Paragon Analytics, Inc. Should you have any questions, please call.

Sincerely,

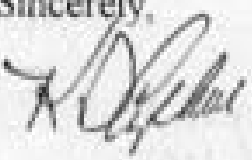

Paragon Analytics, Inc.

Ken Campbell

Project Manager

$\mathrm{KDC} / \mathrm{hc}$

Enclosure: Report 


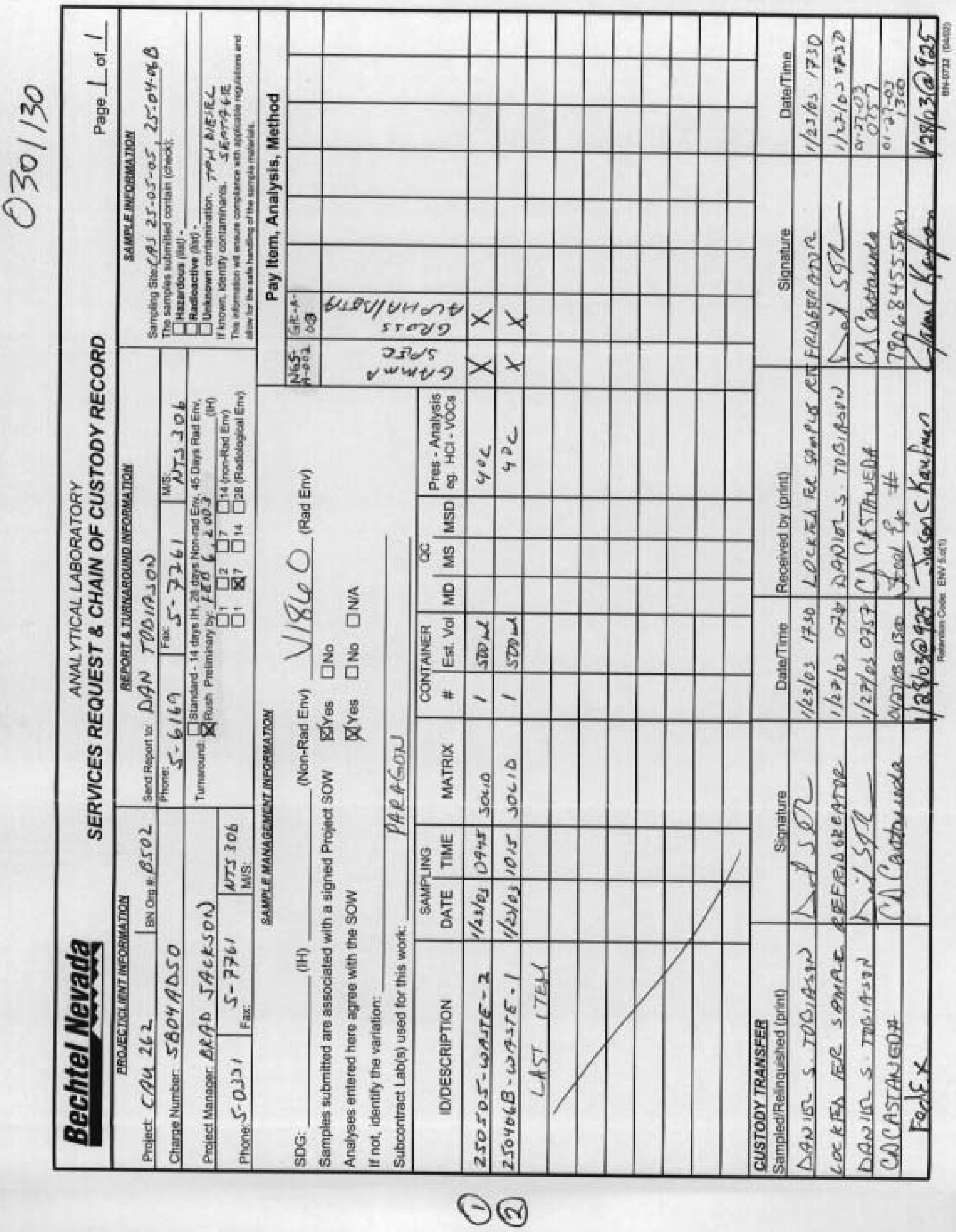




\section{Paragon Analytics, Inc. Radiochemistry Case Narrative Gross Alpha/Beta}

\section{Bechtel Nevada \\ CAU 262 / V1860 \\ PAI WO 0301130}

1. This report consists of two solid samples received by Paragon on $01 / 28 / 03$.

2. These samples were prepared according to Paragon Analytics, Inc. procedure PAI SOP702R15.

3. The samples were analyzed for gross alpha and beta activity by gas flow proportional counting according to Paragon Analytics, Inc. procedure PAI SOP724R7. The analyses were completed ${ }_{90} 02 / 03 / 03$. Gross alpha results are referenced to ${ }^{241} \mathrm{Am}$. Gross beta results are referenced to
${ }_{\mathrm{Sr}} \mathrm{Y}$.

4. The analysis results for these samples are reported on a dry weight basis in units of $\mathrm{pCi} / \mathrm{gram}$.

5. Due to current software limitations, the DER determinations in this report were calculated using the 2 sigma TPU. The SOW indicates that the 1 sigma TPU be used in the DER determination. However, the requested DER limit of less than 3 at the 1 sigma level (which is equivalent to 1.5 at the 2 sigma level) was achieved. Data quality is not affected.

6. All of the solid samples associated with this work order were flamed, as prescribed in EPA Methods 900.0 and 9310 for samples which demonstrate hygroscopicity. This could reduce the beta activity if the samples contained ${ }^{137} \mathrm{Cs}$, or other beta emitters, that may be volatile under the conditions associated with flaming.

7. No anomalous situations were encountered during the preparation or analysis of these samples. All quality control criteria were met.

The data contained in the following report have been reviewed and approved by the personnel listed below. In addition, Paragon Analyties, Ine, certifies that the analyses reported herein are true,

complete and correct within the limits of the methods employed.

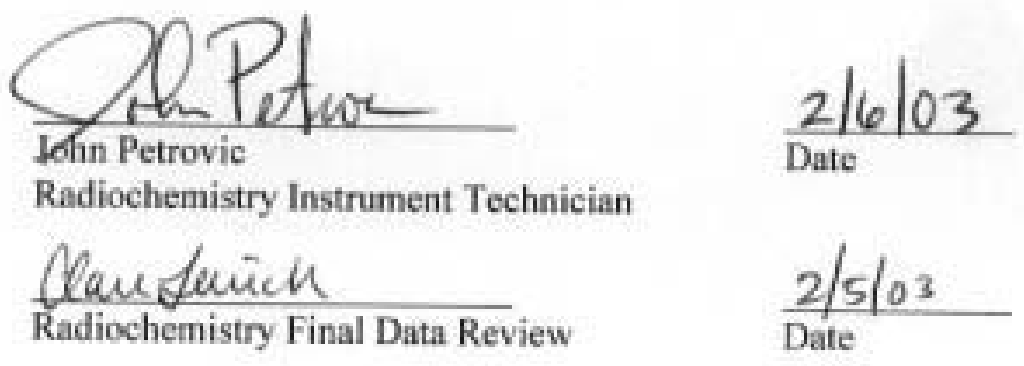




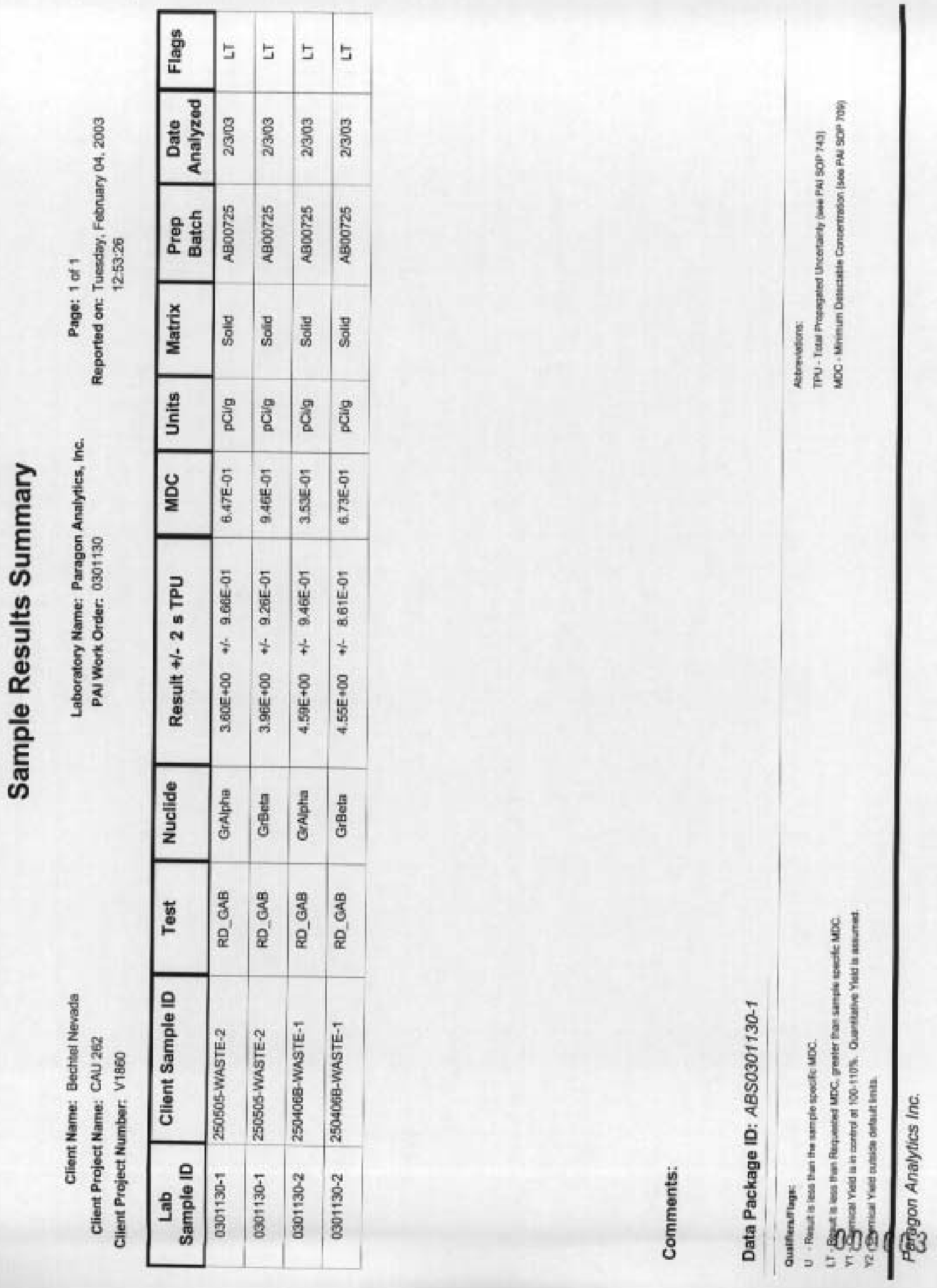




\section{Paragon Analytics, Inc. Radiochemistry Case Narrative Gamma Spectroscopy}

\section{Bechtel Nevada \\ CAU 262 / V1860}

Paragon Work Order 0301130

1. This report consists of analysis results for two solid samples received by Paragon on $1 / 28 / 03$, The analysis results for these samples are reported on a 'dry weight' basis in units of $\mathrm{pCi} / \mathrm{gram}$.

2. These samples were prepared according to Paragon Analytics, Inc, procedure PAI SOP739R5.

3. The samples were analyzed for the presence of gamma emitting radionuclides according to Paragon Analytics, Inc. procedure PAI SOP713R7. The analyses were completed on $1 / 31 / 03$.

4. The samples were analyzed using Seeker Version 2.2, which is a product of Vertechs Software Solutions, Inc.

5. Due to current software limitations, the DER determinations in this report were calculated using the 2 sigma TPU. The SOW indicates that the 1 sigma TPU be used in the DER determination. However, the requested DER limit of less than 3 at the 1 sigma level (which is equivalent to 1.5 at the 2 sigma level) was achieved. Data quality is not affected.

6. No problems were encountered with either the client samples or the associated quality control samples. All quality control criteria were met.

The data contained in the following report have been reviewed and approved by the personnel listed below. In addition, Paragon Analytics, Inc, certifies that the analyses reported herein are true, complete and correct within the limits of the methods employed.
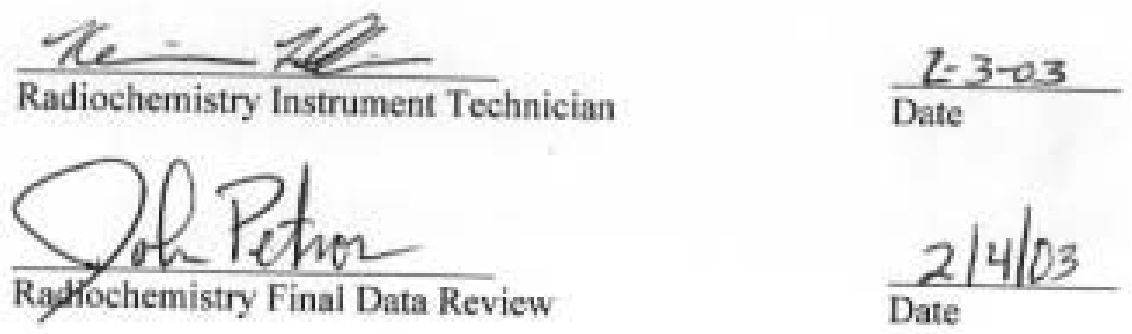


\section{Gamma Spectroscopy Results}

\section{Method PAI 713R7}

\section{Sample Results}

Client Name: Bechtel Nevada Client Project Name: CAU 262 Client Project Number: V1860
Page: 1 of 4

Reported on: Monday, Febnary 03, 2003 18:08-56

Laboratory Name: Paragon Analytics, inc.

PAI Work Order: 0301130
Fieid ID:250505-WASTE-2

Lab ID:0301130-1
Sample Matrix: Solid

Date Prepared: 30-Jan-03

Prep SOP: PAL 739R5

Prep Batch: GS01875
Date Collected: 23-Jan-03

Date Analyzed: 31-Jan-03

Analytical SOP: PAI 713R7

Spectrum Code: 030121D02A
Final Allquot: $101.5 \mathrm{~g}$

Report Basis: Dry Weight

Count Time (min): 30

Library: CAM-A-001L

\begin{tabular}{|c|c|c|c|c|}
\hline Target Nuclide & Result $+1-2$ s TPU & MDC & $\begin{array}{c}\text { Reporting } \\
\text { Units }\end{array}$ & Lab Qualifier \\
\hline$A C-228$ & $1.05 E+00+\%-3.91 E-01$ & 7.5BE-01 & $\mathrm{pClig}$ & \\
\hline Am-241 & $3.28 \mathrm{E}-01+6.64 \mathrm{E}-01$ & $1.13 E+00$ & pClig & $u$ \\
\hline Ce-144 & $-2.02 \mathrm{E}-02+\%-3.65 \mathrm{E}-01$ & 6. 64 E-01 & $\mathrm{pClig}$ & $u$ \\
\hline Co-60 & $-7.97 \mathrm{E}-02+1.20 \mathrm{E}-01$ & 257E-01 & pCilg & $u$ \\
\hline Cs-134 & $6.85 E-03+\gamma-9.19 E-02$ & $1,68 E-01$ & pCing & $u$ \\
\hline Cs-137 & $3.36 \mathrm{E}-02+\%-9.23 \mathrm{E}-02$ & $1.64 E-01$ & $\mathrm{pClig}$ & U \\
\hline Eu-152 & $5.22 \mathrm{E}-01+1-4.46 \mathrm{E}-01$ & 5. $68 \mathrm{EE}-01$ & pCing & $u$ \\
\hline Eu-154 & $-1.13 E-01+\ldots-4.51 E-01$ & 9.39E-01 & pClig & $u$ \\
\hline Eu-155 & $2.32 E-01+h-2.49 E-01$ & 397E-01 & paig & $u$ \\
\hline$K-40$ & $2.1 \mathrm{BE}+01+5.00 \mathrm{E}+00$ & $1.97 E+00$ & pCing & \\
\hline $\mathrm{Pb}-212$ & 1.18E+00+3. 3.24E-01 & 3.12E-01 & pClig & \\
\hline$P m-144$ & $-7.66 E-03+i-9.57 \mathrm{E}-02$ & 1.80E-01 & pCing & $u$ \\
\hline$P m-146$ & $7.53 E-02+f-1.15 E-01$ & 1.91E-01 & pCing & $u$ \\
\hline Ru-106 & $-2.81 E-01+\gamma-8.45 E-01$ & $1.65 E+00$ & pClig & $u$ \\
\hline $5 b-125$ & $3.06 \mathrm{E}-02+\%-2.36 \mathrm{E}-01$ & 4.26E-01 & pCing & $u$ \\
\hline Th-234 & $2.31 E+00 * 1,80 \mathrm{E}+\infty$ & $2.79 E+00$ & $\mathrm{pCi} / \mathrm{g}$ & $u$ \\
\hline U-235 & $2.36 \mathrm{E}-01 * 3-3.94 \mathrm{E}-01$ & $6.59 \mathrm{E}-01$ & $\mathrm{DCl} /{ }_{0}$ & U \\
\hline$Y-88$ & $3.90 \mathrm{E}-02+k-9.58 \mathrm{E}-02$ & $1.71 \mathrm{E}-01$ & $\mathrm{pCi} / g$ & $U$ \\
\hline
\end{tabular}

Data Package ID: GSS0301130-1 


\section{Gamma Spectroscopy Results}

\section{Method PAI 713R7}

\section{Sample Results}

Client Name: Bechtel Nevada

Client Project Name: CAU 262

Client Project Number: V1860
Page; 2 of 4

Reported on: Monday, February 03, 2003 18:06:56

Laboratory Name: Paragon Analytics, Inc.

PAI Work Order: 0301130
Fiald ID:250S05-WASTE-2

Lab 10:0301130-1
Sample Matrix: Solid

Date Prepared: 30-Jan-03

Prep SOP: PAI 739R5

Prep Batch: GS01875
Date Collected: 23-Jan-03

Date Analyzed: 31-Jan-03

Analytical SOP: PAI 713R7

Spectrum Code: 030121D02A
Final Aliquot: $101.5 \mathrm{~g}$

Report Basis: Dry Weight

Count Time (min.) 30

Library: GAM-A-001U

\begin{tabular}{|c|c|c|c|c|}
\hline Target Nuclide & Result $+\% \cdot 2$ s TPU & MDC & $\begin{array}{c}\text { Reporting } \\
\text { Units }\end{array}$ & Lab Qualifier \\
\hline
\end{tabular}

\section{Comments:}

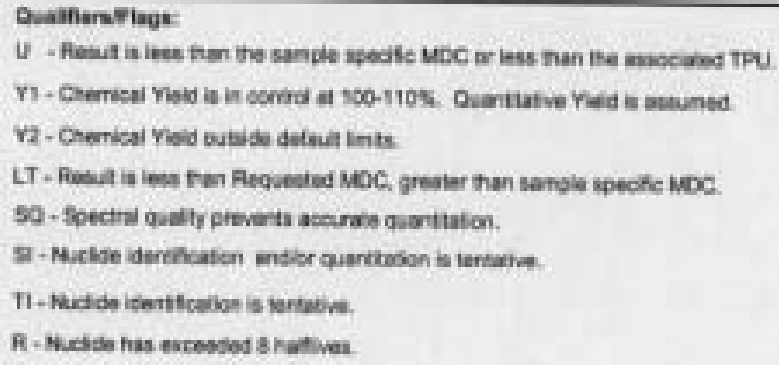

Notreniation:

TFU - Tota Macajated Uscertienty (see PAI SOP 743)

MDC - Mrrtum Delactsile Conoeviraton tase PAi sop 709) 


\section{Gamma Spectroscopy Results}

\section{Method PAI 713R7}

\section{Sample Results}

Client Name: Bechtel Nevada Client Project Name: CAU 262 Client Project Number; V1a60
Page: 3 of 4

Reported on: Monday, February 03, 2003 18:08:56

Laboratory Name: Paragon Analytics, Inc. PAI Work Order: 0301130

Field ID:250406B-WASTE-1
Lab ID:0301130-2

Sample Matrix: Solid Date Prepared: 30-Jan-03 Prep SOP: PAI 73gR5 Prep Batch: GS01875
Date Collected: 23-Jan-03

Date Analyzed: 31-Jan-03

Analytical SOP: PAI 713R7

Spectrum Code: 030109003A
Final Aliquot: 88.70 0

Report Basis: Dry Weight Count Time (min.): 30

Library: G.AM-A.001.U

\begin{tabular}{|c|c|c|c|c|}
\hline Target Nuclide & Result + +2 s TPU & MDC & $\begin{array}{c}\text { Reporting } \\
\text { Units }\end{array}$ & Lab Qualifier \\
\hline$A_{c}-228$ & $1.96 \mathrm{E}+00 * 6.86 \mathrm{E}-01$ & $1.11 E+00$ & $\mathrm{pClng}$ & \\
\hline Am-241 & $5.01 E-01+1-7.08 E-01$ & $1.17 E+\infty 0$ & $\mathrm{pCling}$ & $u$ \\
\hline Ce-144 & $1.12 E-01+5.39 E-01$ & $9.43 E-01$ & $\mathrm{pCi}_{\mathrm{g}}$ & $u$ \\
\hline Co-60 & $-8.34 \mathrm{E}-02+1-1.39 \mathrm{E}-01$ & $3.0 \mathrm{aE}-01$ & $\mathrm{pCV} g$ & $u$ \\
\hline Cs-134 & $1.10 E-02+1.14 E-01$ & $2.09 E-01$ & pCVig & $u$ \\
\hline Cs-137 & $-5.63 E-02+1-1.34 E-01$ & 2.65E-01 & $\mathrm{pCig}$ & $u$ \\
\hline Eu-152 & $-3.50 \mathrm{E}-01+1-5.88 \mathrm{BE}-01$ & $1.36 E+00$ & $\mathrm{DCNg}$ & $u$ \\
\hline Eu-154 & $6.87 \mathrm{E}-01+/ 2.7 .72 \mathrm{E}-01$ & $1.21 E+00$ & pCing & $u$ \\
\hline Eu-155 & 3.90E-01 * 3.31E-01 & 5.10E-01 & pCilg & $u$ \\
\hline$K-40$ & $3.23 E+01+1-7.33 E+00$ & $3.36 \mathrm{E}+00$ & pCing & \\
\hline $\mathrm{Pb}-212$ & $1.81 E+00+1-4.36 \mathrm{E}-01$ & 3.26E-01 & pCilg & \\
\hline$P_{m-144}$ & $1.13 \mathrm{E}-01+\%-1.39 \mathrm{E}-01$ & 2.25E-01 & $\mathrm{pCi} g$ & U \\
\hline$P_{m-146}$ & $1,34 \mathrm{E}-02 * 1.57 \mathrm{E}-01$ & 2.84E-01 & pCing & $u$ \\
\hline Ru-106 & $-7.52 \mathrm{E}-01+1.28 \mathrm{E}+00$ & $2.53 E+00$ & pCug & $u$ \\
\hline $8 b-125$ & $0.00 E+00 * 1.2 .65 E-01$ & $4.98 E-01$ & $\mathrm{pCVig}$ & $u$ \\
\hline Th-234 & $-1.56 \mathrm{E}-01+2.08 \mathrm{E}+00$ & $3.63 \mathrm{E}+00$ & $\rho \mathrm{CV}_{\mathrm{g}}$ & $u$ \\
\hline U.235 & $1.04 E-04+1-5.75 E-01$ & $1.02 E+00$ & pCivg & $u$ \\
\hline$Y-88$ & $-1.83 E-02+1.51 E-01$ & $2.92 E-01$ & $\mathrm{pON}$ & U \\
\hline
\end{tabular}

Data Package ID: GSS0301130-1 


\section{Gamma Spectroscopy Results}

\section{Method PAI 713R7}

\section{Sample Results}

Client Name: Bechtel Nevada

Client Project Name: CAU 262

Client Project Number: V18e0
Page: 4 of 4

Reported on: Monday, February 03, 2003 18:08:56

Laboratory Name: Paragon Analytics, Inc.

PAI Work Order: 0301130
Field ID:250406B-WASTE-1

Lab ID:0301130-2
Sample Matrix: Solid

Date Prepared: 30-Jan-03

Prep SOP: PAI $739 R 5$

Prep Batch: GS01875
Date Collected: 23-Jan-03

Date Analyzed: 31-Jan-03

Analytical SOP: PAI 713R7

Spectrum Code: 030109003A
Final Aliquot: $80.70 \mathrm{~g}$

Report Basis: Dry Weight

Count Time (min.): 30

Library: GAM-h-00t.L

\begin{tabular}{|c|c|c|c|c|}
\hline Target Nuclide & Result $+/ 2$ s TPU & MDC & $\begin{array}{c}\text { Reporting } \\
\text { Units }\end{array}$ & Lab Qualifier \\
\hline
\end{tabular}

\section{Comments:}

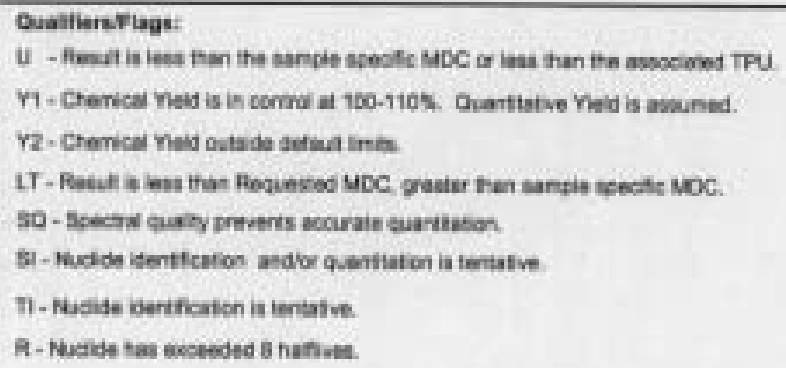

\section{Nabreilations:}

TPU - Fol Fropogeted Uncertakty isee Pai sop 743;

MDC-Metimum Delectatis Consertnsion ise FN SCP 703 ? 
225 Commerce Drive * Fort Collins, CO 80524 * (800) 443-1511 * (970) 490-1511 * FAX (970) 490-1522

February 20, 2003

Mr. Ted Redding

Bechtel Nevada

US DOE Zone 1, Bldg 652, Rm 2. M/S NTS273

Mercury, NV, 89023

RE; Paragon Workorder: 03-02-018

Client Project Name: CAU 262

Client Project Number: V1885

Dear Mr. Redding:

One soil sample was received from Bechtel Nevada on February 7, 2003. The samples were scheduled for Gross Alpha/Beta (pages 1-147) and Gamma Spectroscopy (pages 1108 ) analyses. The results for these analyses are contained in the enclosed reports.

Thank you for your confidence in Paragon Analytics, Inc. Should you have any questions, please call.

Sincerely,

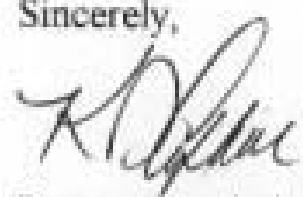

Paragon Analytics, Inc.

Ken Campbell

Project Manager

$\mathrm{KDC} / \mathrm{he}$

Enclosure: Report 


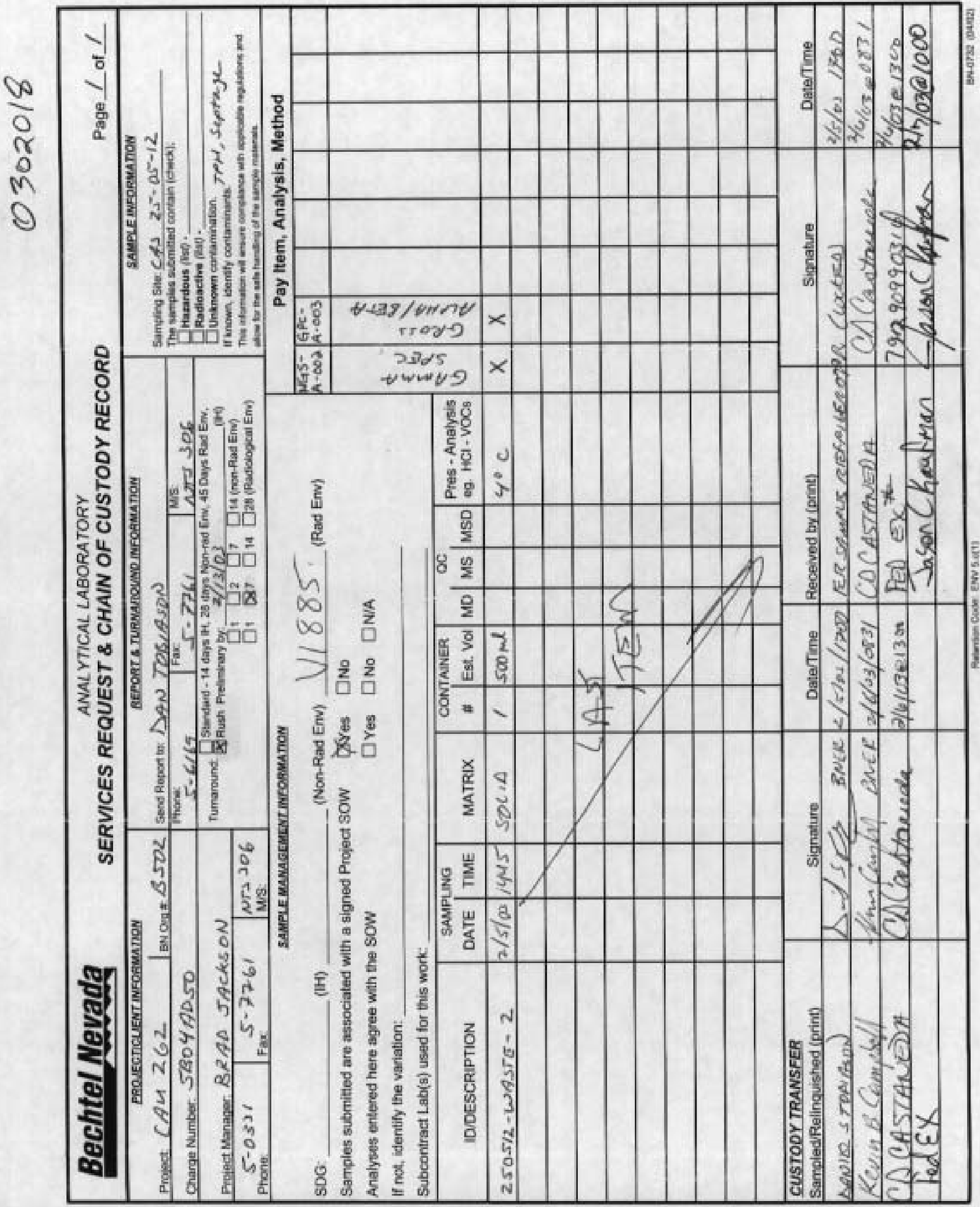




\section{Paragon Analytics, Inc. Radiochemistry Case Narrative Gross Alpha/Beta}

\section{Bechtel Nevada \\ CAU 262 / V1885 \\ PAI WO 0302018}

1. This report consists of one soil sample received by Paragon on 2/7/03.

2. This sample was prepared according to Paragon Analytics, Inc, procedure PAI SOP702RI5.

3. The sample was analyzed for gross alpha and beta activity by gas flow proportional counting according to Paragon Analytics, Inc, procedure PAI SOP724R7. The analyses were completed on $2 / 13 / 03$. Gross alpha results are referenced to ${ }^{241} \mathrm{Am}$. Gross beta results are referenced to ${ }^{90} \mathrm{Sr} / \mathrm{Y}$.

4. The analysis results for this sample are reported on a dry weight basis in units of $\mathrm{pCi} / \mathrm{gram}$.

5. This sample was flamed, as prescribed in EPA Methods 900.0 and 9310 for samples which demonstrate hygroscopicity. This could reduce the beta activity if the sample contained ${ }^{139} \mathrm{Cs}$, or other beta emitters, that may be volatile under the conditions associated with flaming.

6. Due to current software limitations, the DER determinations in this report were calculated using the 2 sigma TPU. The SOW indicates that the 1 sigma TPU be used in the DER determination. However, the requested DER limit of less than 3 at the 1 sigma level (which is equivalent to 1.5 at the 2 sigma level) was achieved. Data quality is not affected.

7. No further anomalous situations were noted during the preparation and analysis of this sample. All remaining quality control criteria were met.

The data contained in the following report have been reviewed and approved by the personnel listed below. In addition, Paragon Analytics, Inc, certifies that the analyses reported herein are true, complete and correct within the limits of the methods employed.

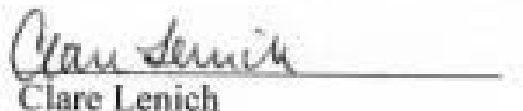

Clare Lenich

Radiochemistry Instrument Technician

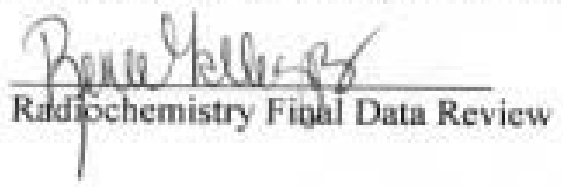

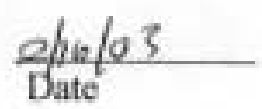

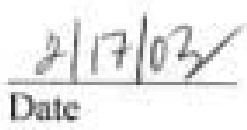



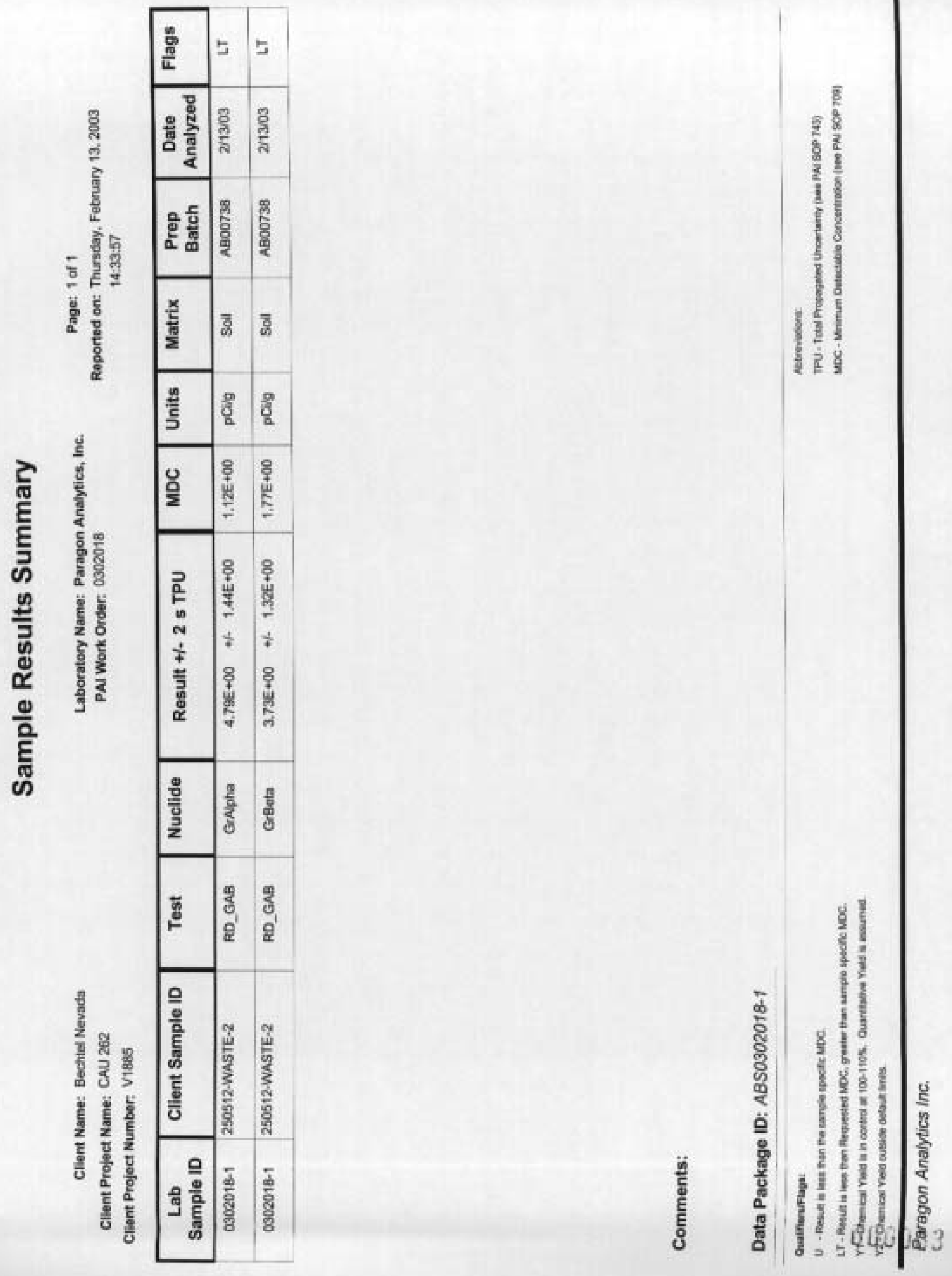


\title{
Paragon Analytics, Inc. Radiochemistry Case Narrative Gamma Spectroscopy
}

\section{Bechtel Nevada CAU 262 / V1885}

\author{
Paragon Work Order 0302018
}

1. This report consists of analysis results for one soil sample received by Paragon on 2/7/03. The analysis results for this sample are reported on a 'dry weight' basis in units of pCi/gram.

2. This sample was prepared according to Paragon Analytics, Inc, procedure PAI SOP739R5.

3. The sample was analyzed for the presence of gamma emitting radionuclides according to Paragon Analytics, Ine, procedure PAI SOP713R7. The analyses were completed on $2 / 11 / 03$,

4. The samples were analyzed using Seeker Version 2.2, which is a product of Vertechs Software Solutions, Inc.

5. Due to current software limitations, the DER determinations in this report were calculated using the 2 sigma TPU. The SOW indicates that the I sigma TPU be used in the DER determination. However, the requested DER limit of less than 3 at the 1 sigma level (which is equivalent to 1.5 at the 2 sigma level) was achieved. Data quality is not affected.

6. Duplicate analysis results elevated above the DER limit of 1.50 have been flagged as "W". For gamma spectroscopic analysis SOP $715 R 12$ states that $75 \%$ of the nuclides must be within the 2 sigma control limit to meet DER or RPD requirements. Elevated DER may be attributable to sample non-homogeneity.

7. Activity concentrations above the $2 \sigma$ TPU are reported in some instances where minimum nuclide identification criteria are not met. Such tentative identifications result when the software attempts to calculate net activity concentrations for analytes where either one or both of the following criteria are not satisfied: the 'diagnostic' peak for a nuclide must be identified above critical level (generally the most abundant, interference-free photopeak), or the minimum library peak tolerance of $75 \%$ must be attained. These data have been flagged with a "TT" qualifier.

8. There are cases where the magnitude of the negative activity is greater than the 2 sigma TPU. The analyst's review of the data does not indicate a problem with the instrument data or the subsequent reporting systems. The data quality is not believed to be affected and the results are submitted without qualification. Under typical conditions, where background level sample data is normally distributed and analyzed by paired observations, this event is likely to occur at least $2.5 \%$ of the time. 
9. No problems were encountered with either the client samples or the associated quality control samples. All quality control criteria were met.

The data contained in the following report have been reviewed and approved by the personnel listed below. In addition, Paragon Analytics, Inc, certifies that the analyses reported herein are true, complete and correct within the limits of the methods employed.

$$
\frac{2-13-03}{\text { Date }}
$$
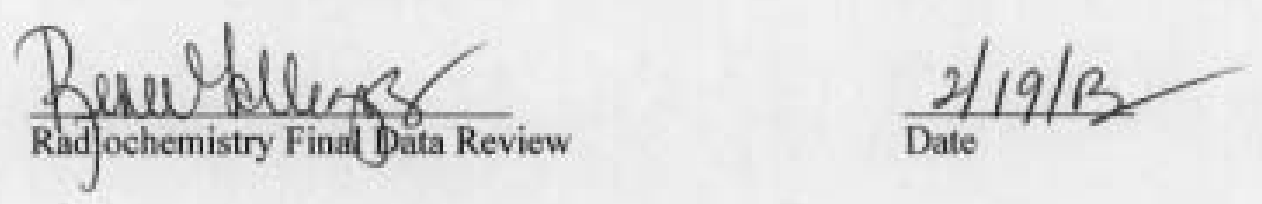

000002 


\section{Gamma Spectroscopy Results}

\section{Method PAI 713R7}

\section{Sample Results}

Client Name: Bechtel Nevada

Client Project Name: CAU 262

Client Project Number: V1885
Page: 1 of 2

Reported on: Wednescay. February 12, 2003

17:43:16

Laboratory Name: Paragon Analytics, Inc.

PAI Work Order: 0302018
Field ID:250512.WASTE-2

Lab ID;0302018-1
Sample Matrix: Soil

Date Prepared: 11-Feb-03

Prep SOP: PAN 739R5

Prep Batch: GS01894
Date Collected: 05-Feb-03

Date Analyzed: 11-Feb-03

Analytical SOP: PAI 713R7

Spectrum Code: 080245D01A
Final Aliquot: $100.0 \mathrm{~g}$

Report Basis: Dry Weight

Count Time (min.): 30

Library: GaM-A-001.U

\begin{tabular}{|c|c|c|c|c|}
\hline Target Nuclide & Result $+1-2$ s TPU & MDC & $\begin{array}{c}\text { Reporting } \\
\text { Units }\end{array}$ & Lab Qualifier \\
\hline Ac- 228 & $1.31 E+00 * 3.90 E-01$ & $6.64 E-01$ & pCirg & \\
\hline$A m-241$ & $-3.34 \mathrm{E}-01+/-2.96 \mathrm{E}-01$ & $5.44 E-01$ & pCirg & $u$ \\
\hline Ce-144 & $2.07 E-01+i-3.54 E-01$ & 5. $.99 E-01$ & pCing & $u$ \\
\hline $\mathrm{Co}-60$ & $-3.35 E-02+1-7.98 E-02$ & $1.53 E-01$ & $\mathrm{pCNg}$ & U \\
\hline Cs-134 & $-1.01 E-01+1-1.18 E-01$ & 2.19E-01 & pCig & $u$ \\
\hline Cs-137 & $2.13 E-01+1.08 E-01$ & $1,42 \mathrm{E}-01$ & $\mathrm{pCi} g$ & $\mathrm{TI}$ \\
\hline Eu-152 & $-1.91 \mathrm{E}-01+4 \cdot 4.25 \mathrm{E}-01$ & $8.11 \mathrm{E}-01$ & pCilg & $U$ \\
\hline Eu-154 & $-8.14 E-02+1-4.74 E-01$ & $8.62 E-01$ & $\mathrm{pClig}$ & $u$ \\
\hline EU-15S & $9.49 \mathrm{E}-02+1 \cdot 2.12 \mathrm{E}-01$ & $3.57 E-01$ & $\mathrm{pCi} / \mathrm{g}$ & $\mathbf{u}$ \\
\hline$K-40$ & $2.61 E+01+5.10 E+00$ & $2,42 \mathrm{E}+00$ & $\mathrm{pCV} / \mathrm{g}$ & \\
\hline $\mathrm{Pb}-212$ & $1.26 \mathrm{E}+00+1-2.90 \mathrm{E}-01$ & $2.51 E=01$ & pCigs & \\
\hline$P m=144$ & $1.07 E-02+\%-8.26 E-02$ & $1,44 E=01$ & pCigg & U \\
\hline Pm-146 & $6.35 E-02 * 8.8 .54 E-02$ & $1,40 E-01$ & pCilg & $U$ \\
\hline$R u-106$ & $-4.97 \mathrm{E}-01+f-7.27 \mathrm{E}-01$ & $1.35 E+\infty$ & $\mathrm{pCl} / \mathrm{g}$ & U \\
\hline $5 b-125$ & $-8.62 E-02+1.71 E-01$ & 323E-01 & pCirg & $u$ \\
\hline Th-234 & $6.17 E-01+1.1 .01 E+\infty 0$ & $1.67 E+00$ & pCing & $U$ \\
\hline U-235 & $4.69 E-02+\%, 3.71 E-01$ & 6.35E-01 & pCig & $U$ \\
\hline Y-88 & $-7.2 \mathrm{BE}-02+\%-9.62 \mathrm{E}-02$ & $1.81 E-01$ & pCig & $u$ \\
\hline
\end{tabular}

Data Package ID: GSS0302018-1 


\section{Gamma Spectroscopy Results}

\section{Method PAI 713R7}

\section{Sample Results}

Client Name: Bechtel Nevada

Client Project Name: CAU 262

Client Project Number: V1885
Page: 2 of 2

Reported on: Wednesday, February 12, 2003

17:43:16

Laboratory Name: Paragon Analytics, Inc.

PAI Work Order: 0302018
Fiesd 1D:250512-WASTE-2

Lab 10:0302018-1
Sample Matrix: Soil

Date Prepared: 11-Feb-03

Prep SOP: PAl 73aR5

Prep Batch: GS01894
Date Collected: 05-Feb-03

Date Analyzed: 11-Feb-03

Anatytical SOP: PAI 713R7

Spectrum Code: 030245D01A
Final Allquot: $100.0 \mathrm{~g}$

Report Basis: Dry Weight

Count Time (min.): 30

Library: GAM-A.001.L

Target Nuclide

Result +1- 2 s TPU

MDC

Reporting

Lab Qualifier Units

\section{Comments:}

\section{Quaifierafflags:}

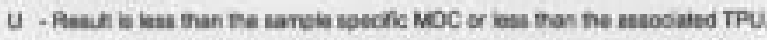

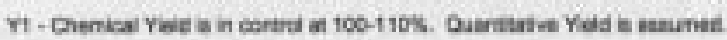

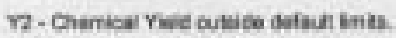

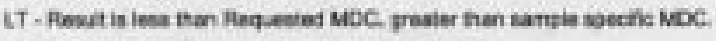

50-5sectre quaby preserh scrarate auartiation

si - Mucide isenticatios arder quentiation is lortative.

7-Nudide bernitaton in ietafive

R-Nuclas has eareated 4 hafives.
Abbovisters

TFU - Tou Prosegaied Uncertaitiy (see PAI BOP 743)

MOC - Mhimum Dentatatie Conoertiation (see PA SOP 709

Data Package ID: GSS0302018-1 
CLOSURE RE PORT - CAU 262

Section: Appendix B

Revision : 1

Date: July 2003

THIS PAGE INTENTIONALLY LEFT BLANK 


\section{APPENDIX C}

\section{SOIL COMPACTION TEST RESULTS}


CLOSURE RE PORT - CAU 262

Section: Appendix C

Revision : 1

Date: July 2003

THIS PAGE INTENTIONALLY LEFT BLANK 


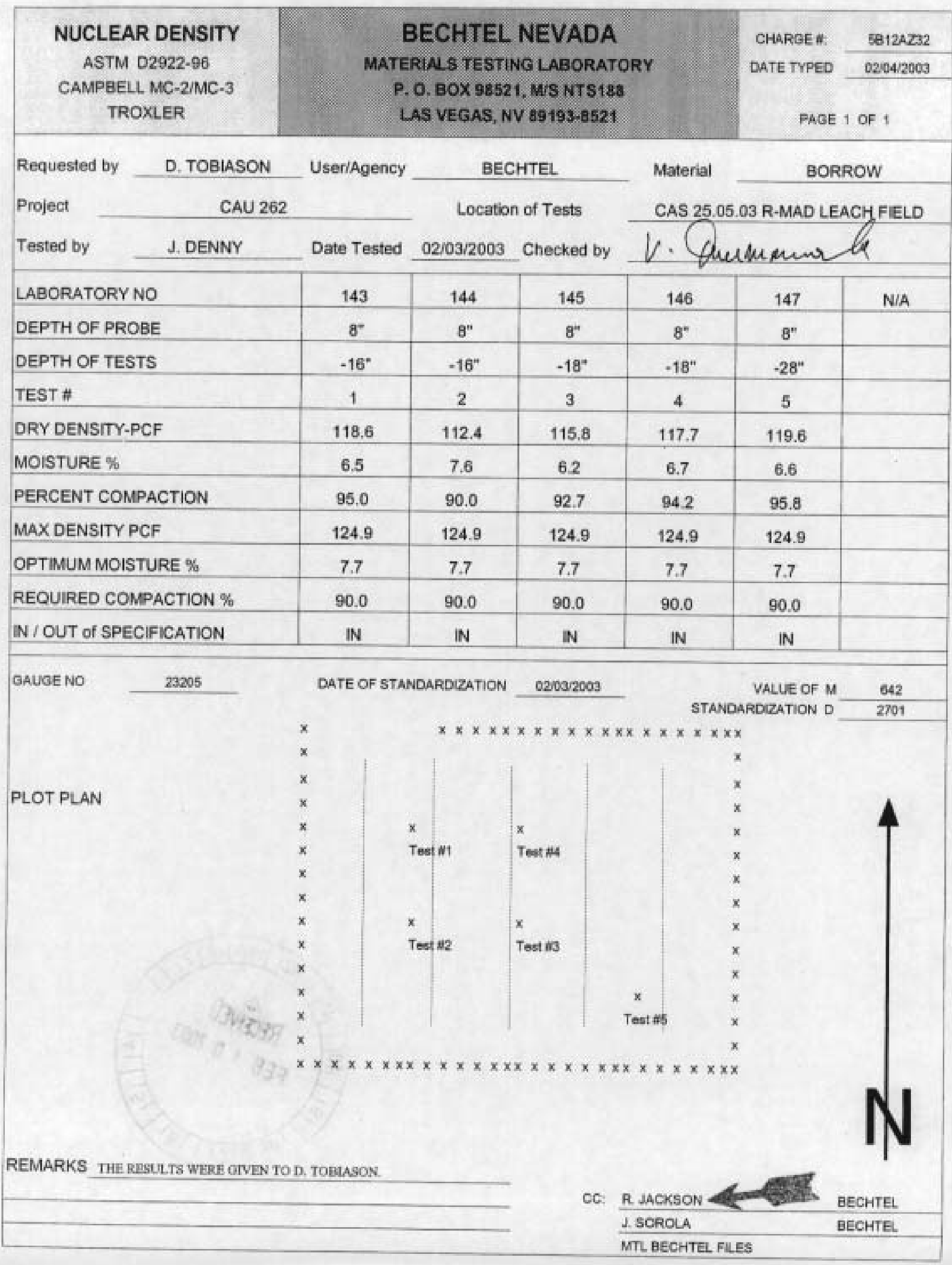




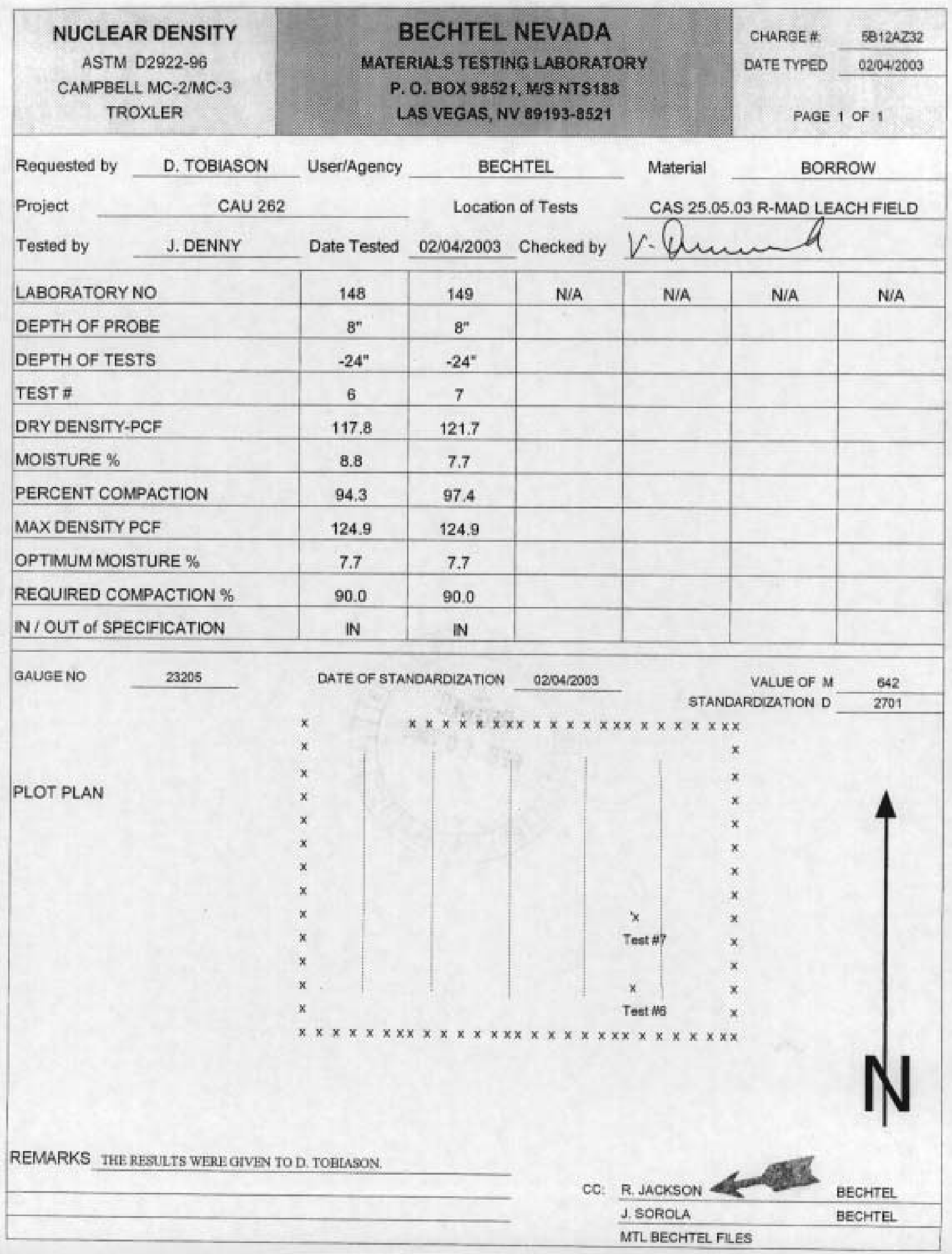




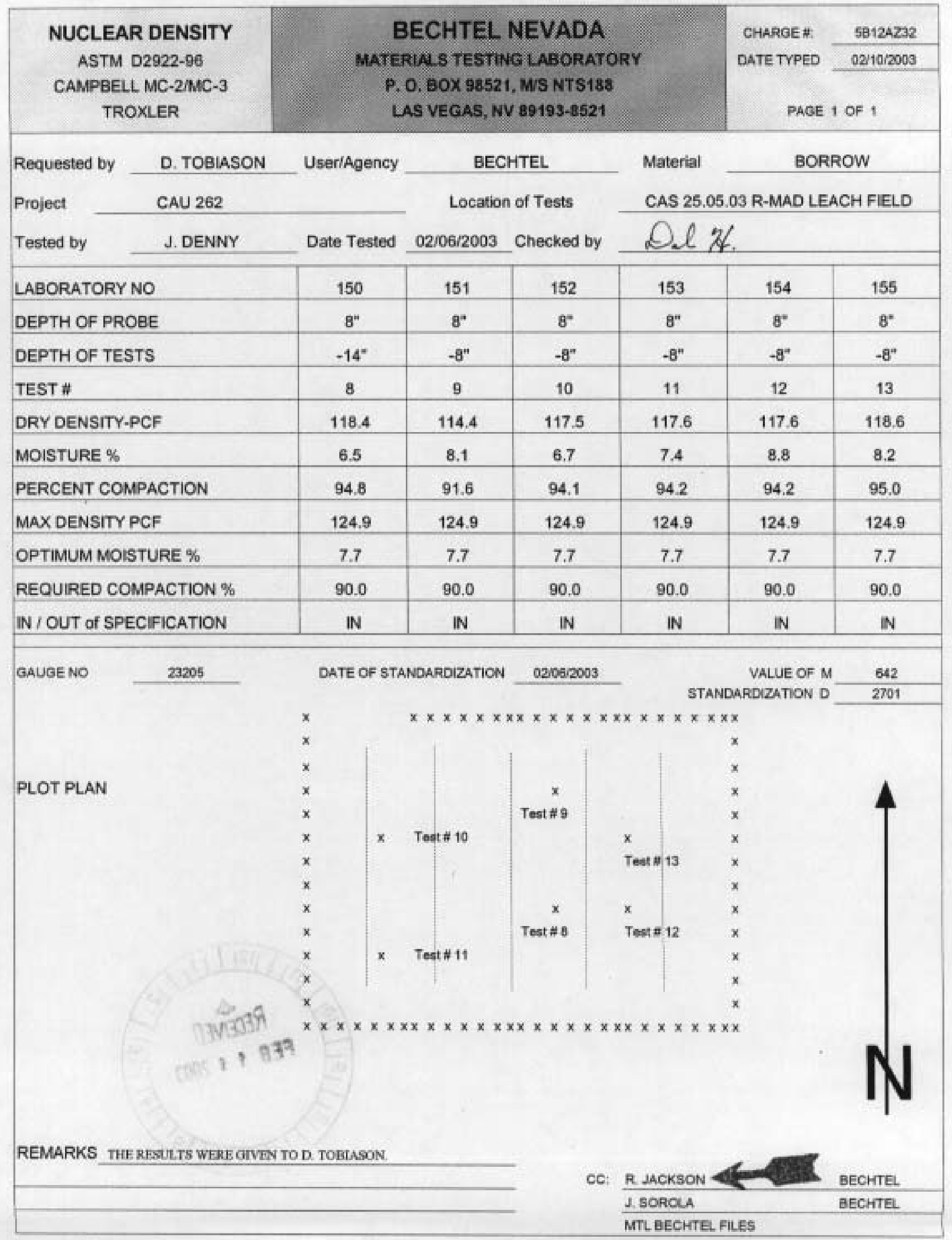




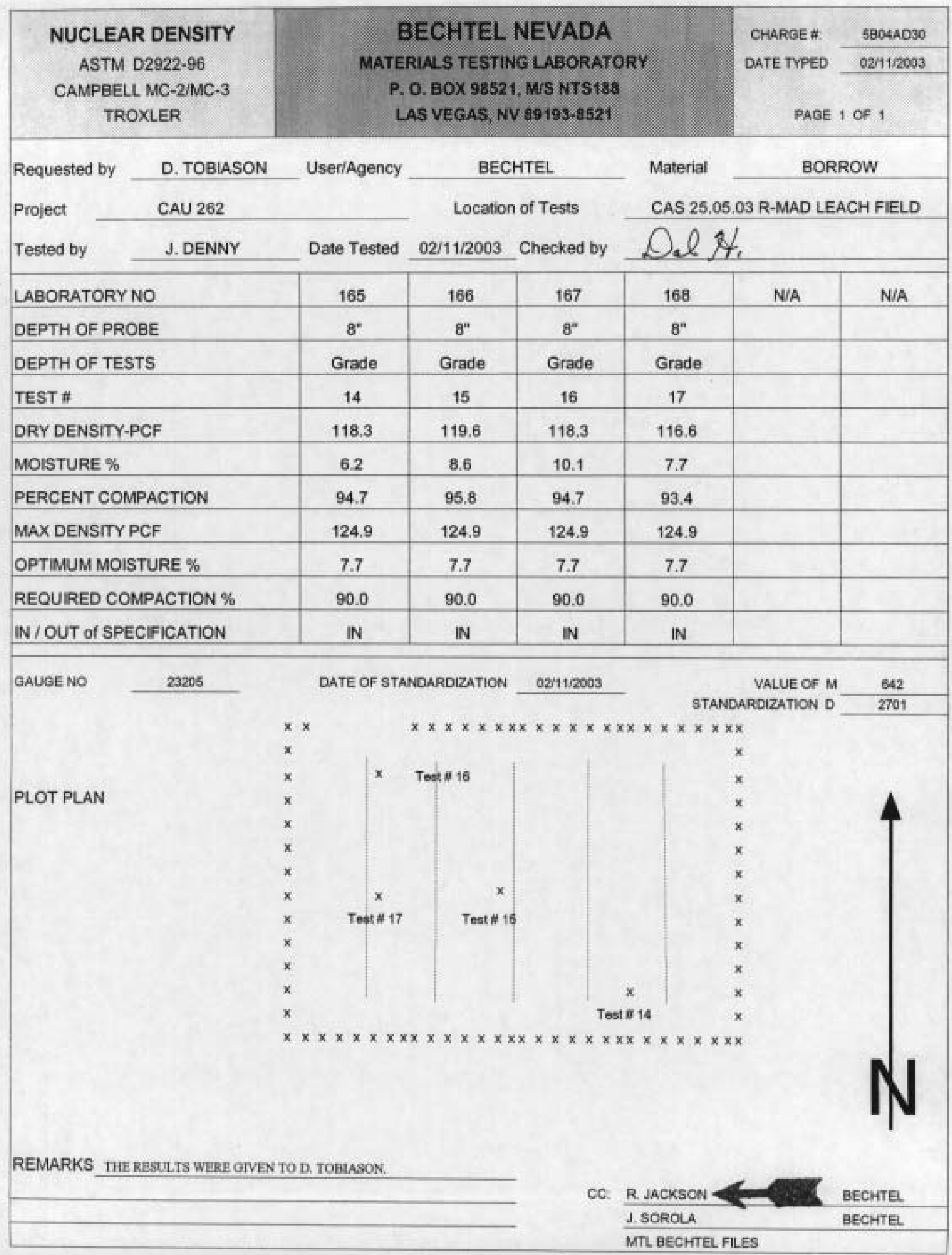




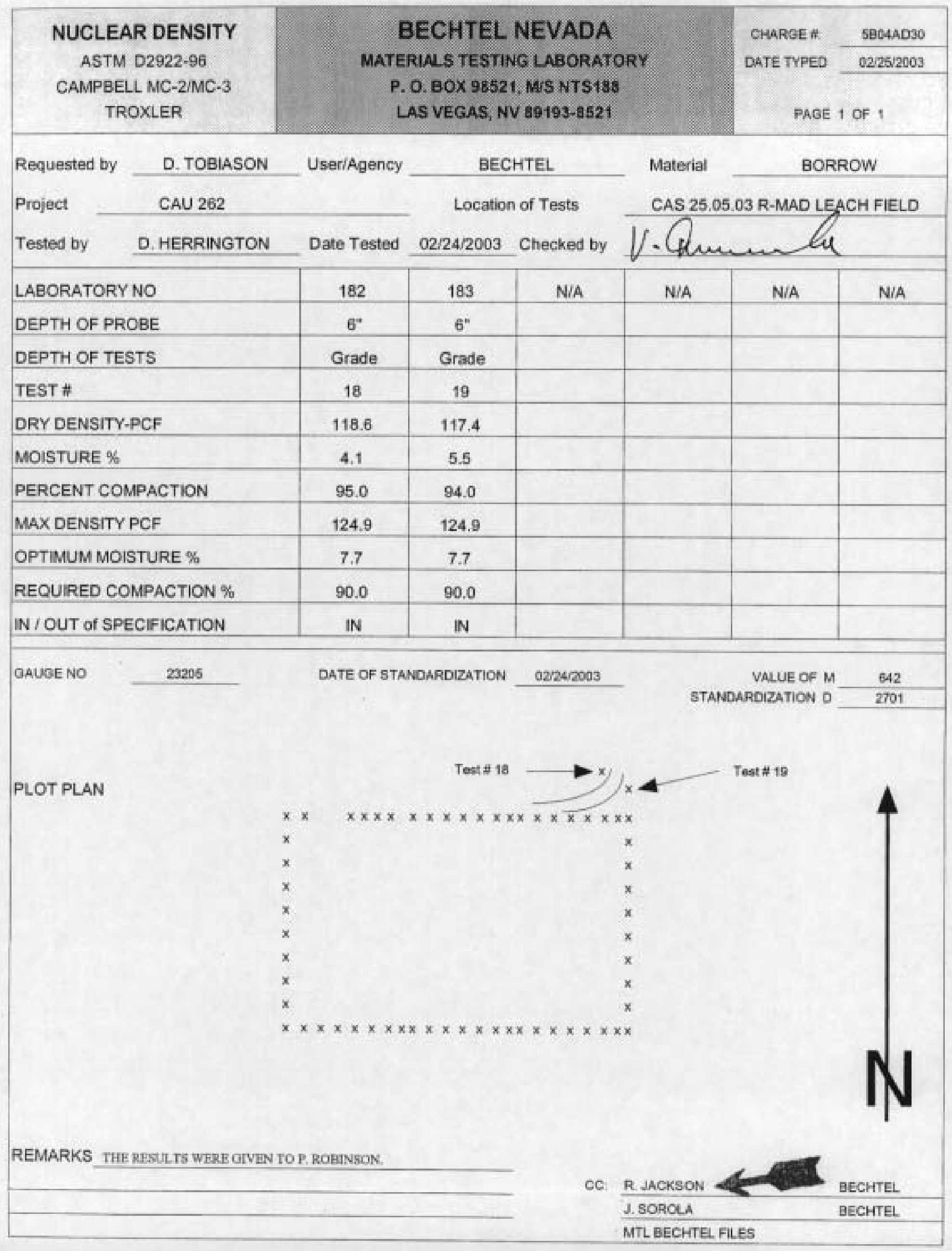


NUCLEAR DENSITY

ASTM D2922-96

CAMPBELL MC-2/MC-3

TROXLER
BECHTEL NEVADA

MATERIALS TESTING LABORATORY

P. O. BOX 98521, M/S NTS188

LAS VEGAS, NV 89 193-8521
CHARGE\#

DATE TYPEO

59O4AD90

$04 / 03 / 2003$

PAGE 1 OF 1
Requested by

D. TOBLASON

User/Agency

CAU 262

Project

Tested by

D. HERRINGTON

Date Tested 04/02/2003

Location of Tests

Checked by

Material

BORROW

\begin{tabular}{|c|c|c|c|c|c|c|}
\hline LABORATORYNO & 442 & N/A & N/A & N/A & N/A & N/A \\
\hline DEPTH OF PROBE & $4^{*}$ & & & & & \\
\hline DEPTH OF TESTS & Final Grade & & & & & \\
\hline TEST \# & 20 & & & & & \\
\hline DRY DENSITY-PCF & 115.9 & & & & & \\
\hline MOISTURE \% & 5.0 & & & & & \\
\hline PERCENT COMPACTION & 92.8 & & & & & \\
\hline MAX DENSITY PCF & 124.9 & & & & & \\
\hline OPTIMUM MOISTURE \% & 7.7 & & & & & \\
\hline REQUIRED COMPACTION \% & 90.0 & & & & & \\
\hline IN / OUT OF SPECIFICATION & $\mathbb{N}$ & & & & & \\
\hline
\end{tabular}

GAUGE NO

23205

DATE OF STANDARDIZATION

$04 / 02 / 2003$

\section{CAS 25.05.03 R-MAD LEACH FIELD}
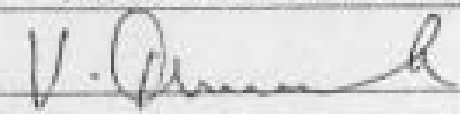

\section{PLOT PLAN}

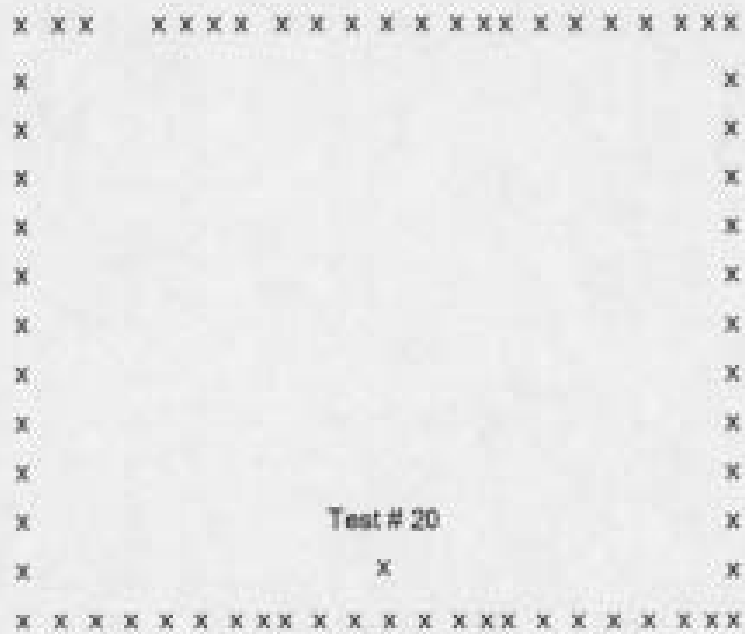




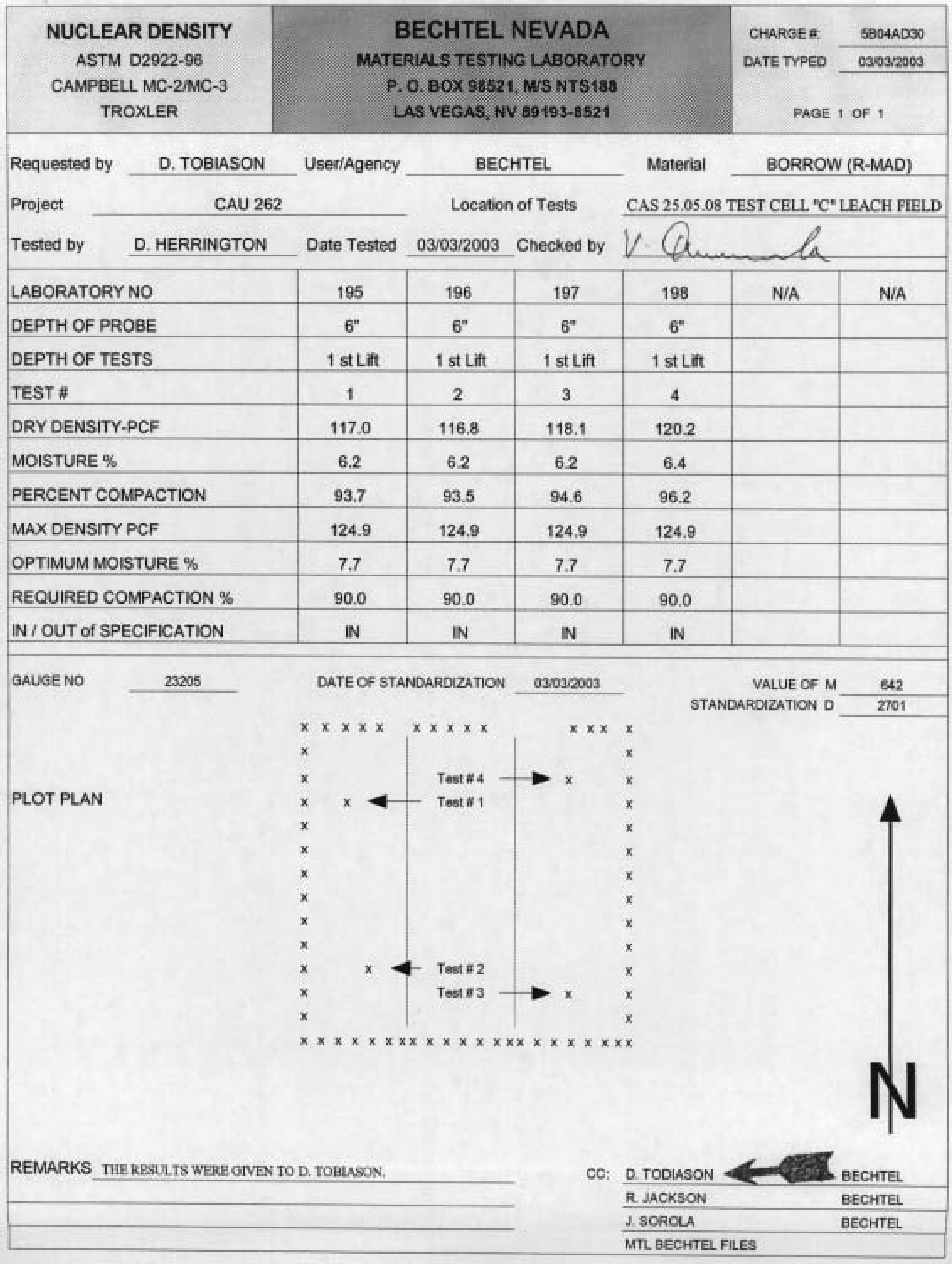




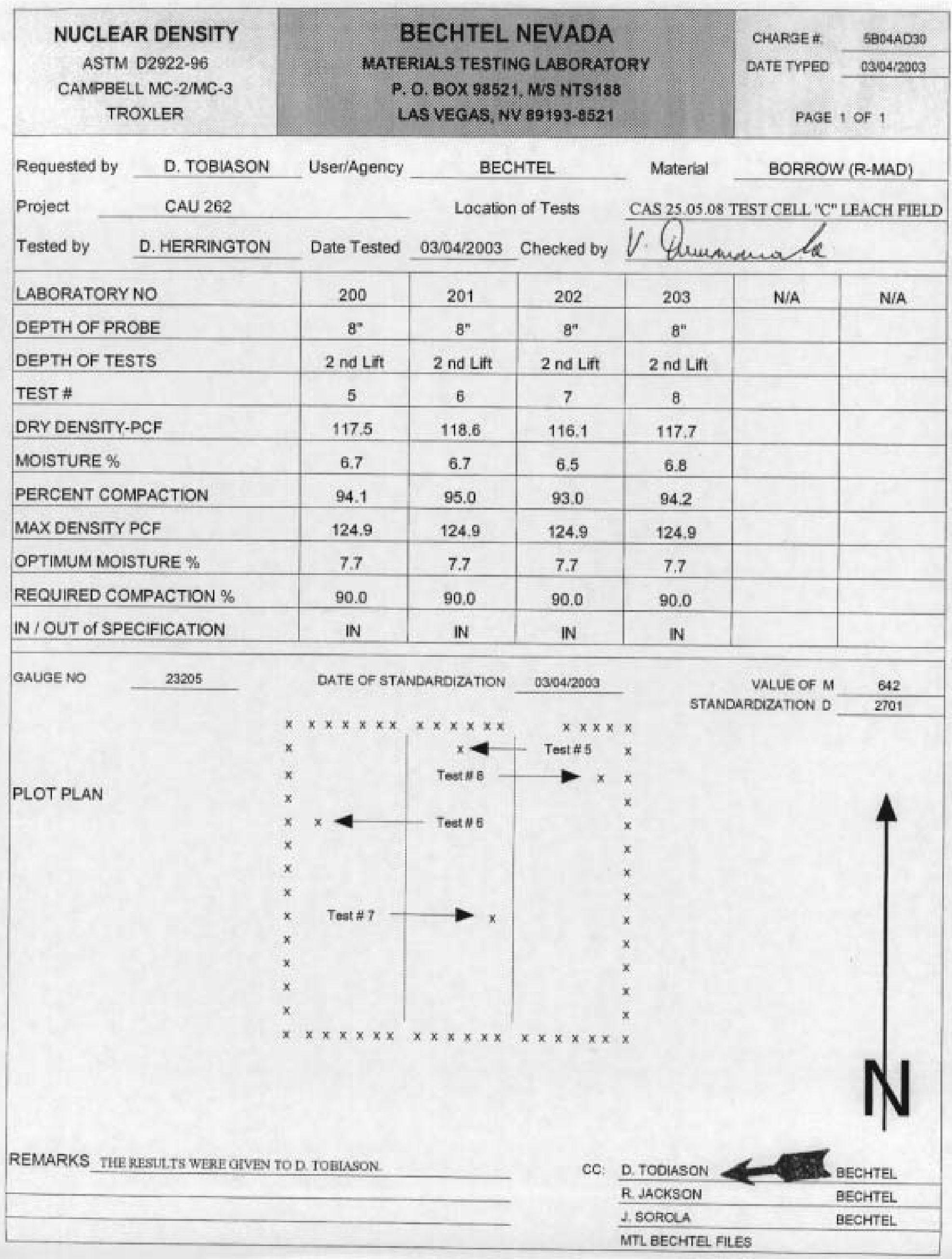




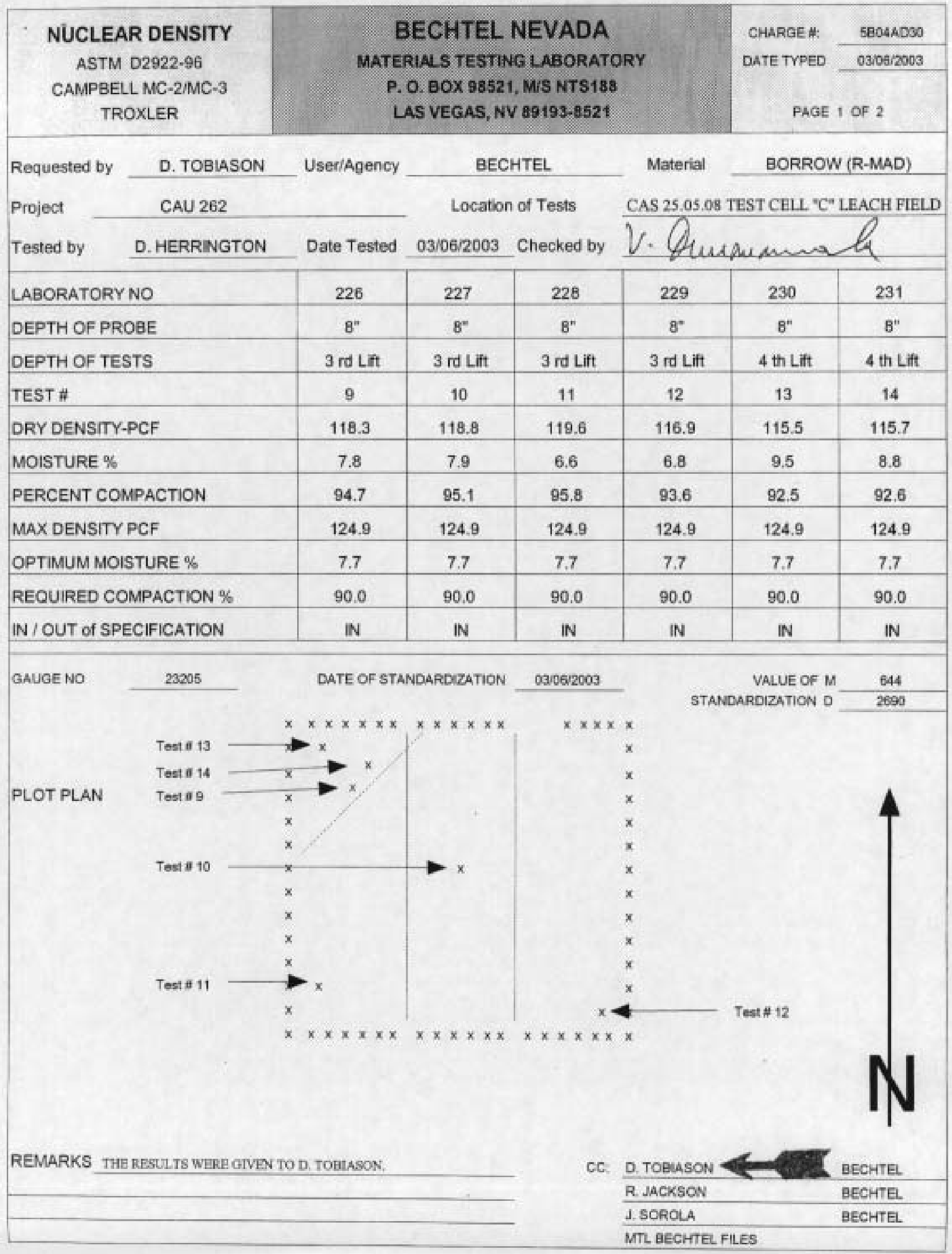




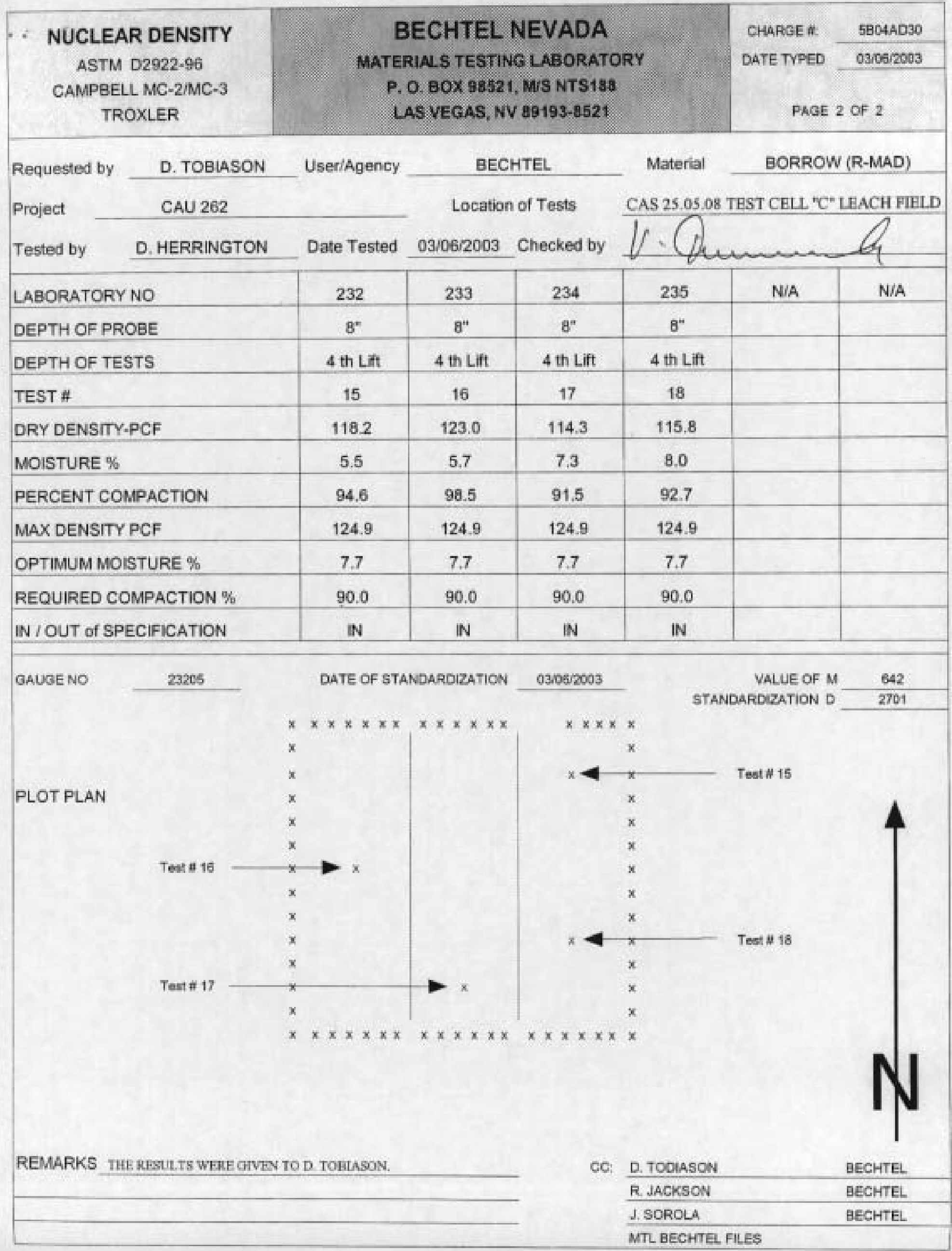




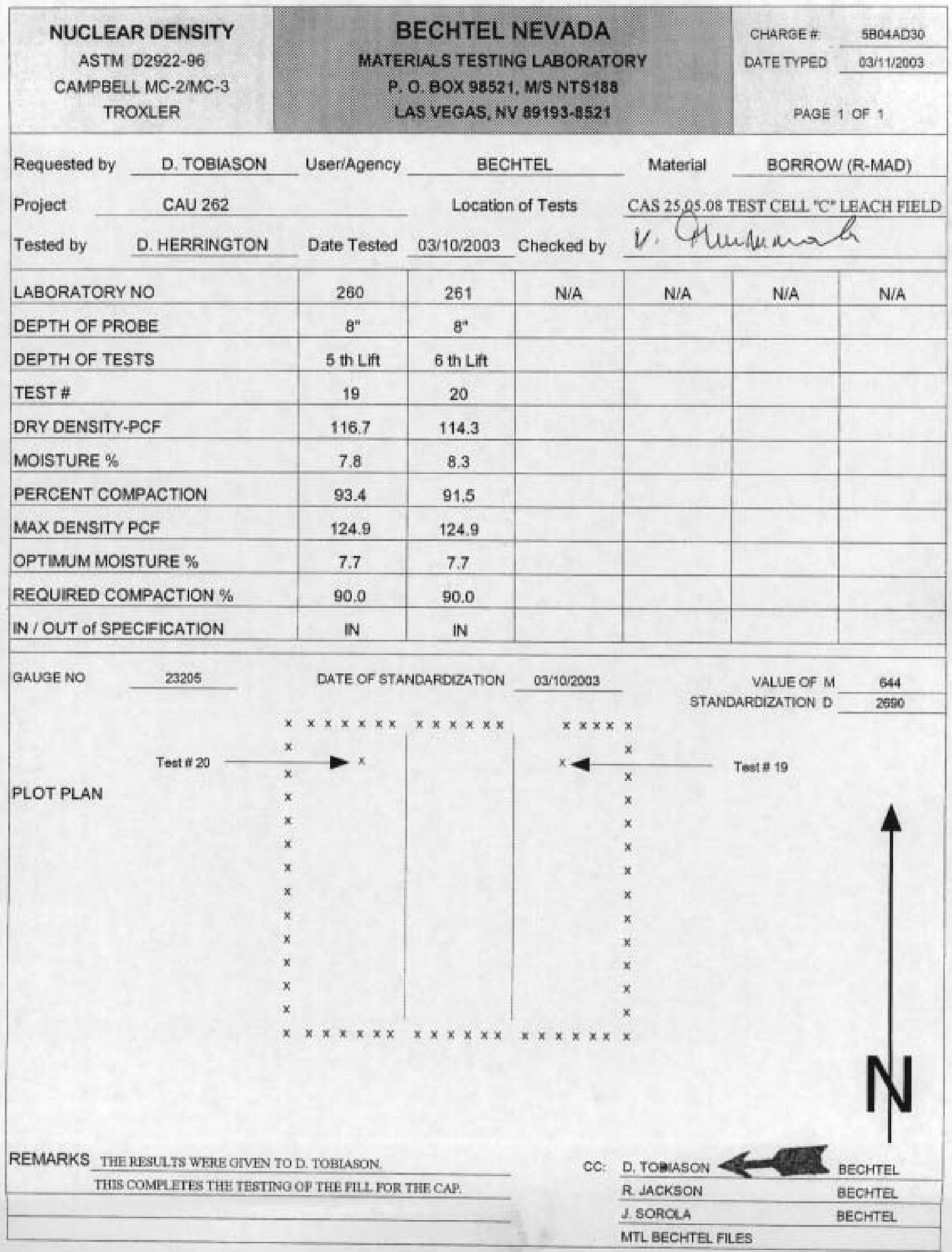


NUCLEAR DENSITY

ASTM D2922-96

CAMPBELL MC-2/MC-3 TROXLER
BECHTEL NEVADA

MATERIALS TESTING LABORATORY

P. O. BOX 98521 , M/S NTS188

LAS VEGAS, NV 89193-8521
CHARGE \# P 5B04AD30

DATE TYPED O4/03/2003

PAGE 1 OF 1

\begin{tabular}{|c|c|c|c|c|c|c|}
\hline D. TOBLASON & \multirow[t]{2}{*}{ User/Agency } & \multicolumn{2}{|c|}{ BECHTEL } & Material & \multicolumn{2}{|c|}{ BORROW (R-MAD) } \\
\hline CAU 262 & & \multicolumn{2}{|c|}{ Location of Tests } & CAS 25.05 .0 & CELL & CH FIELD \\
\hline D. HERRINGTON & Date Tested & $04 / 02 / 2003$ & Checked by & & & \\
\hline LABORATORY NO & 440 & 441 & N/A & N/A & N/A & N/A \\
\hline DEPTH OF PROBE & $6^{*}$ & $6^{\prime \prime}$ & & & & \\
\hline DEPTH OF TESTS & Final Grade & Final Grade & & & & \\
\hline TEST \# & 21 & 22 & & & & \\
\hline DRY DENSITY-PCF & 115.1 & 112.6 & & & & \\
\hline MOISTURE \% & 6.5 & 6.1 & & & & \\
\hline PERCENT COMPACTION & 92.2 & 90.1 & & & & \\
\hline MAX DENSITY PCF & 124.9 & 124.9 & & & & \\
\hline OPTIMUM MOISTURE \% & 7.7 & 7.7 & & & & \\
\hline REQUIRED COMPACTION \% & 90.0 & 90.0 & & & & \\
\hline IN / OUT of SPECIFICATION & $\mathbb{N}$ & IN & & & & \\
\hline
\end{tabular}

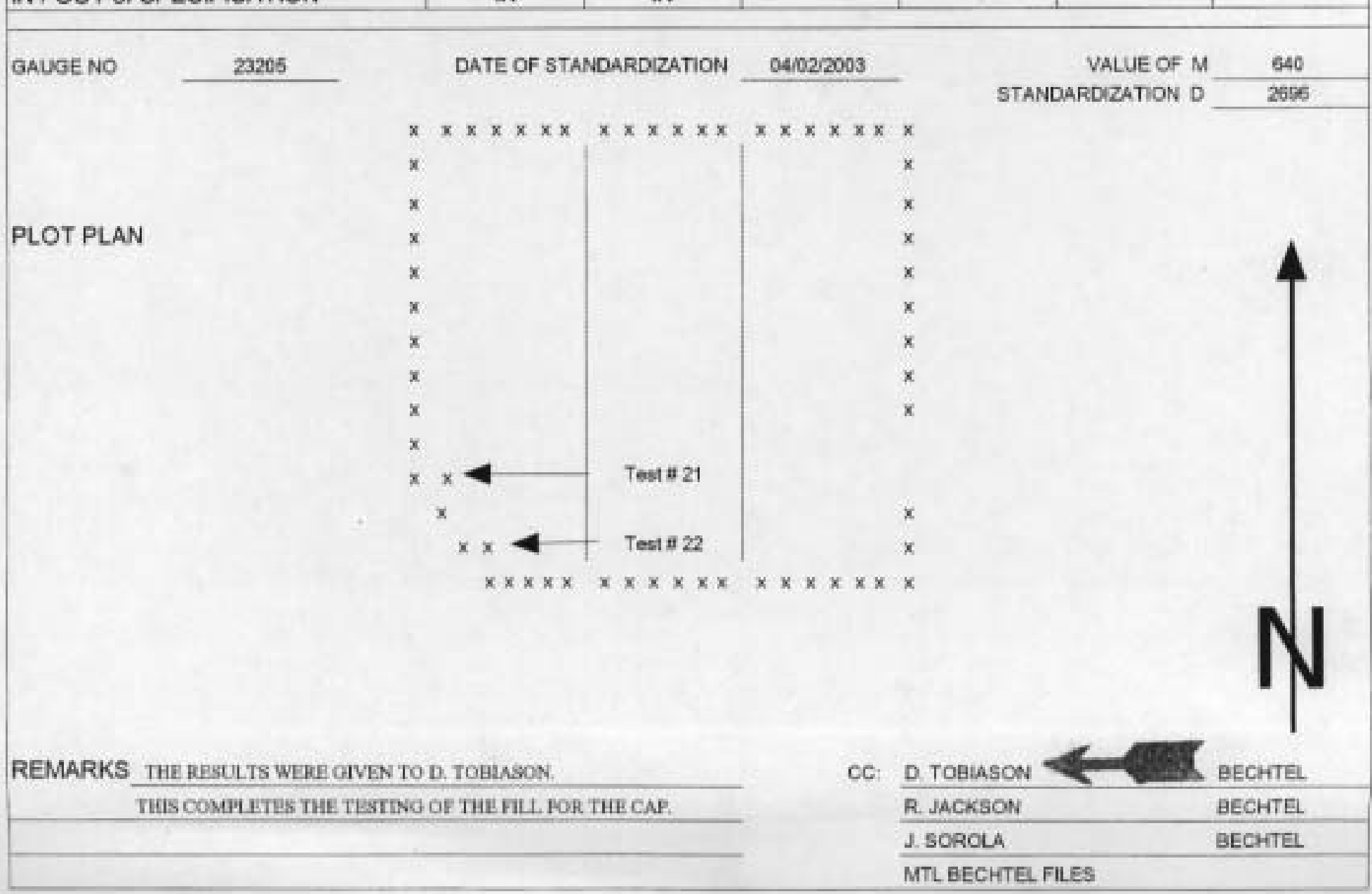




\section{APPENDIX D}

\section{RADIOLOGICAL SURVEY REPORTS}


CLOSURE RE PORT - CAU 262

Section: Appendix D

Revision : 1

Date: July 2003

THIS PAGE INTENTIONALLY LEFT BLANK 


\section{RADIOLOGICAL SURVEY REPORT LOG}

\begin{tabular}{|l|l|}
\hline CAS NUMBER & RADIOLOGICAL SURVEY REPORT NUMBER \\
\hline $25-05-03$ & $03-E R ~ 25-42$ \\
\hline $25-05-06$ & 03-ER-25-41, 03-ER-25-191, 03-ER-25-215, 03-ER-25-644 \\
\hline $25-05-08$ & 03-ER-25-151, 03-ER-25-324, 03-ER-25-644 \\
\hline
\end{tabular}


CLOSURE RE PORT - CAU 262

Section: Appendix D

Revision : 1

Date: July 2003

THIS PAGE INTENTIONALLY LEFT BLANK 


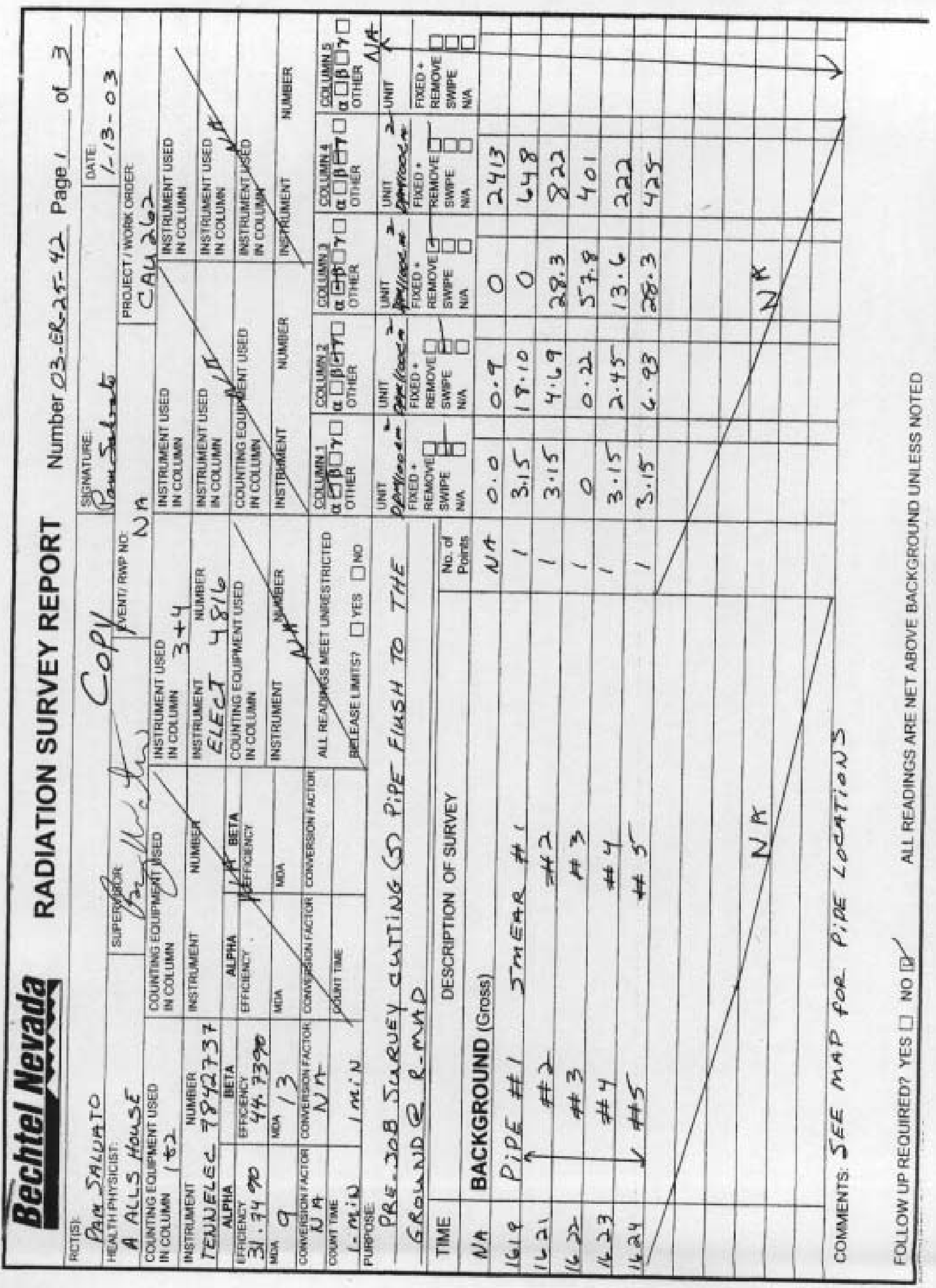




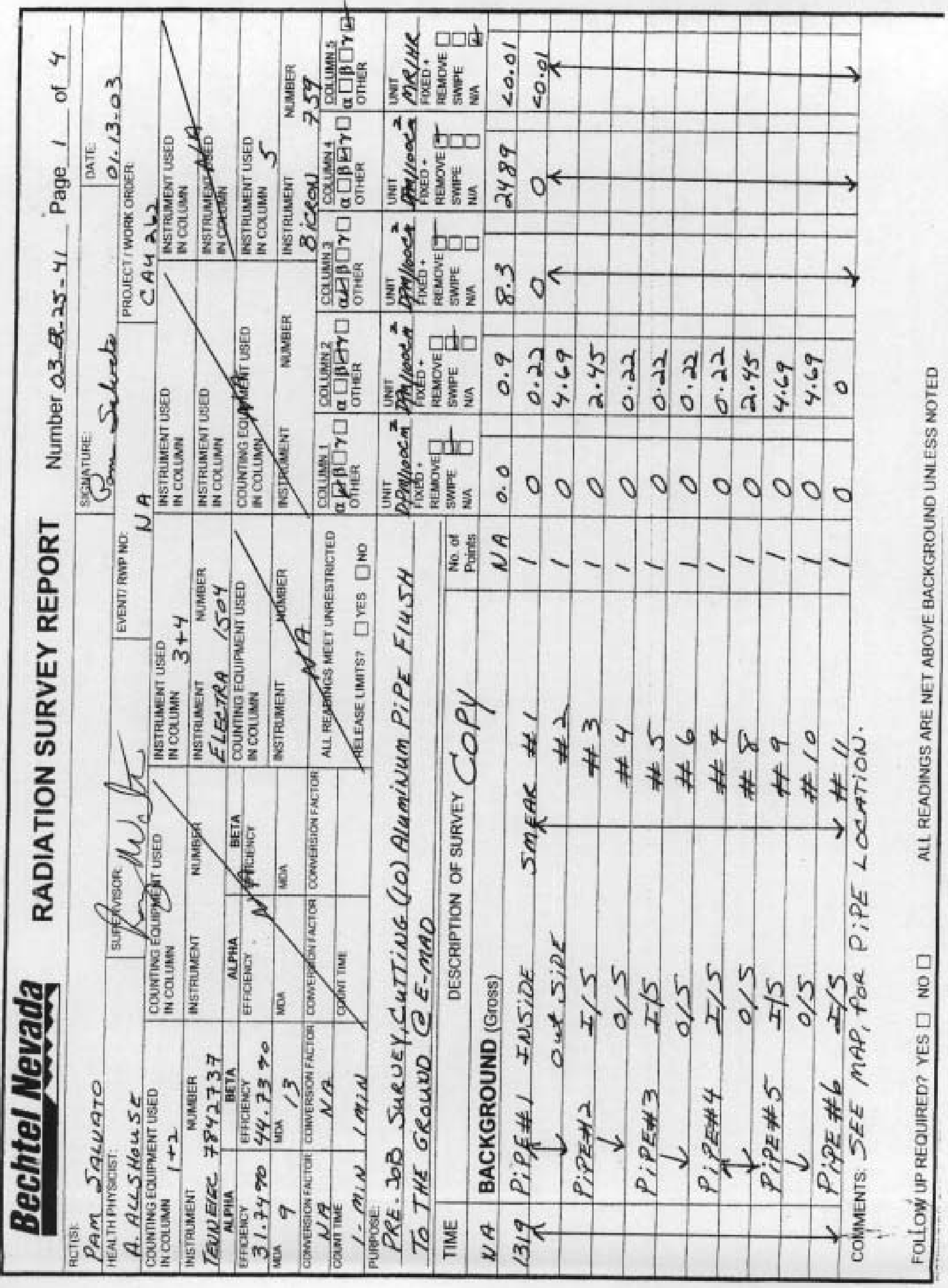




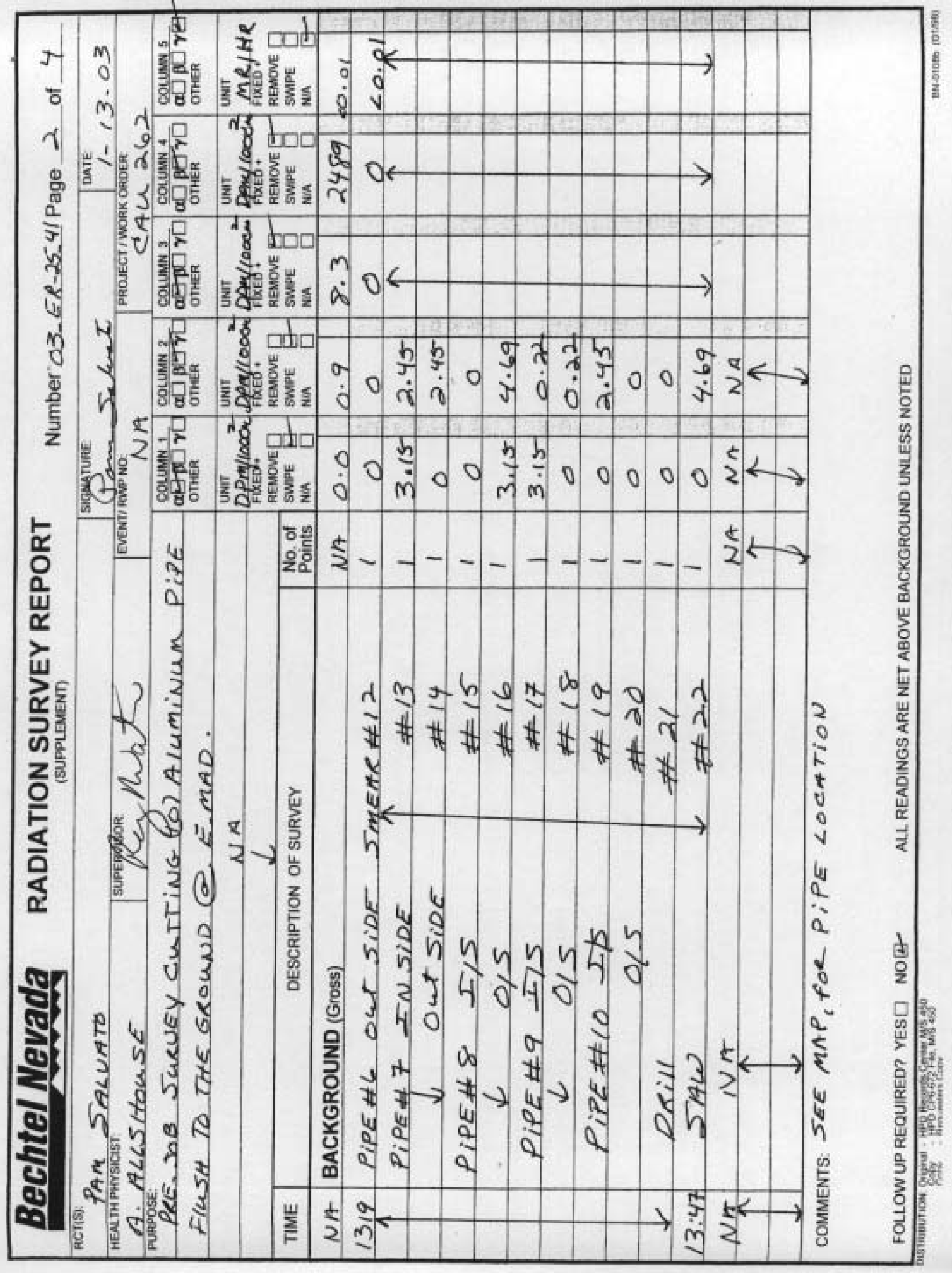




\section{7)

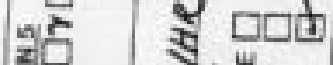

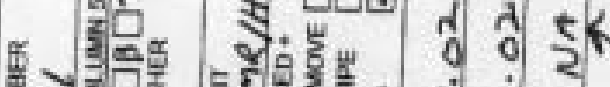

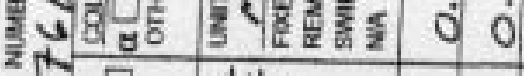

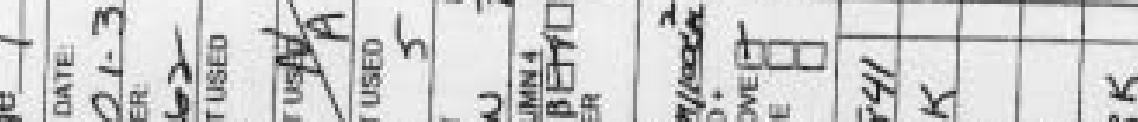

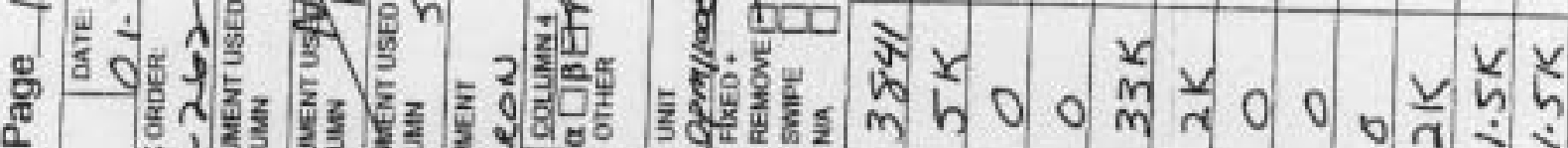

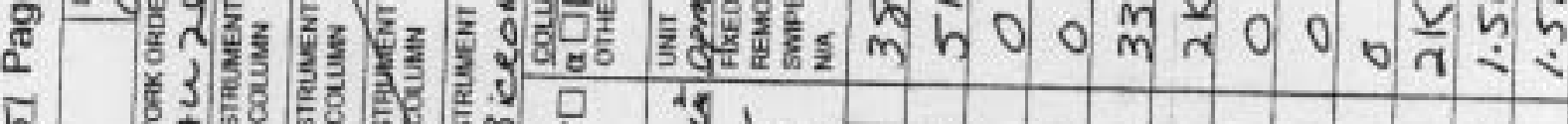

5.

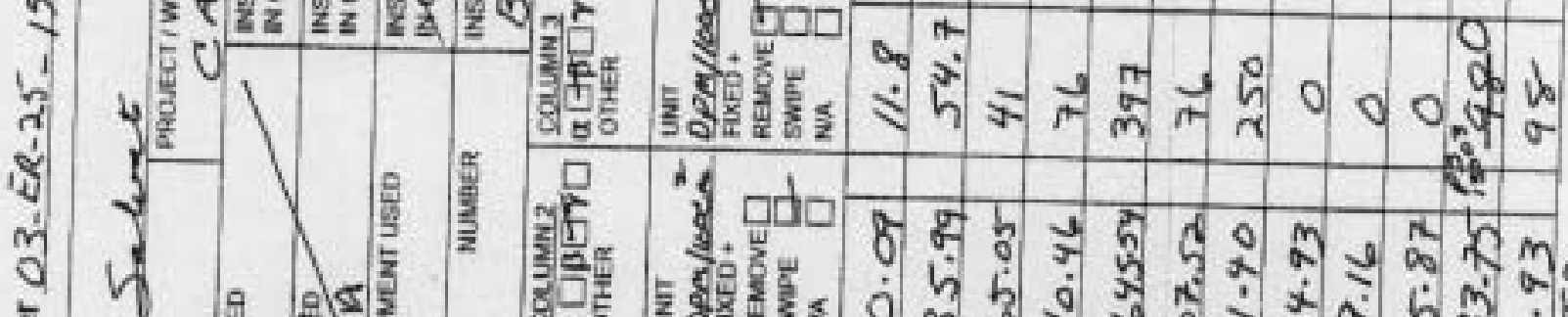

है

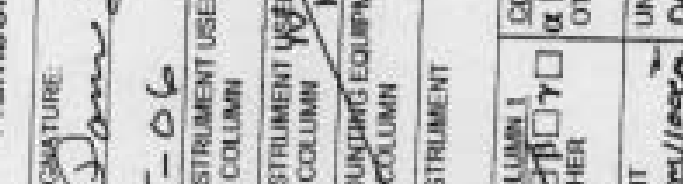

(3) 1

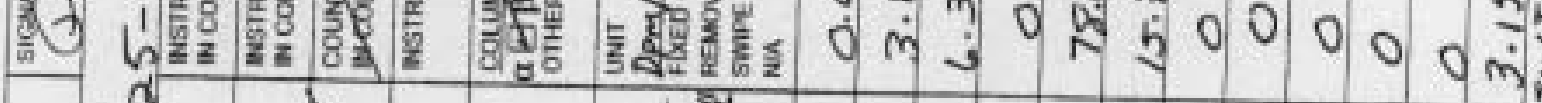

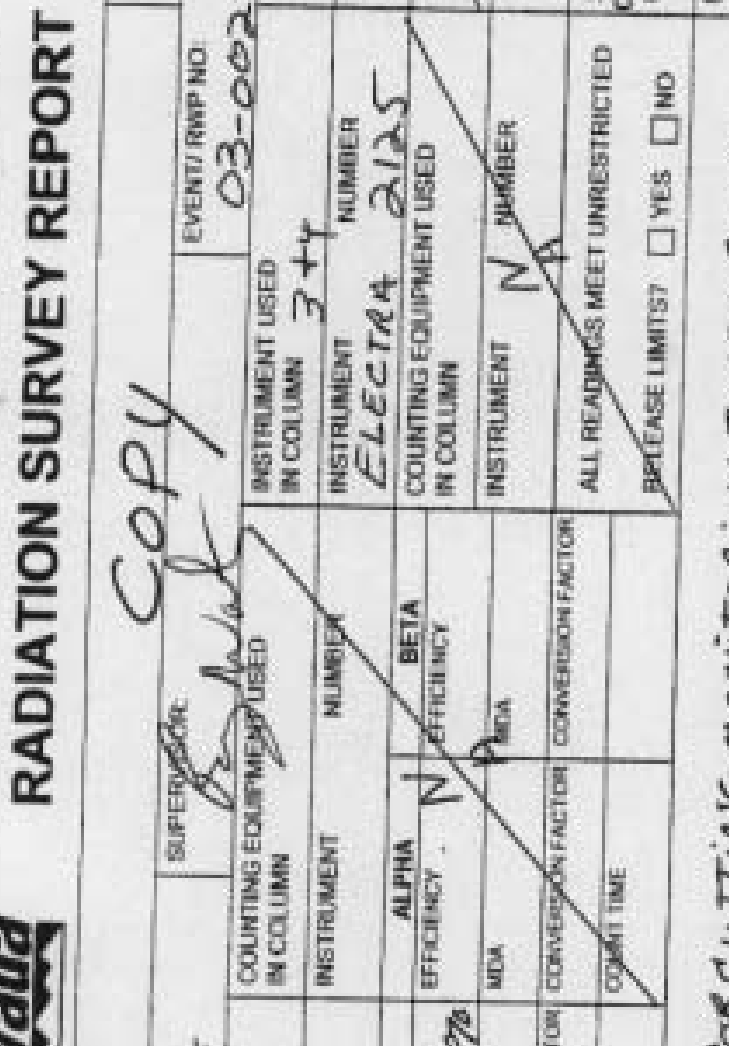

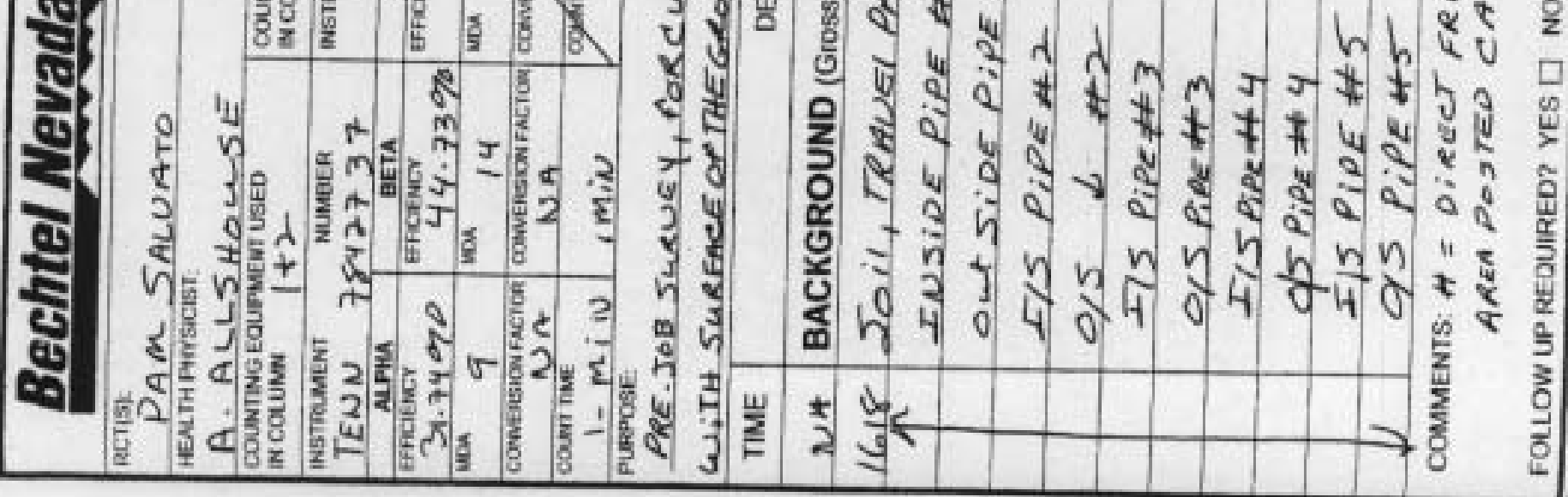




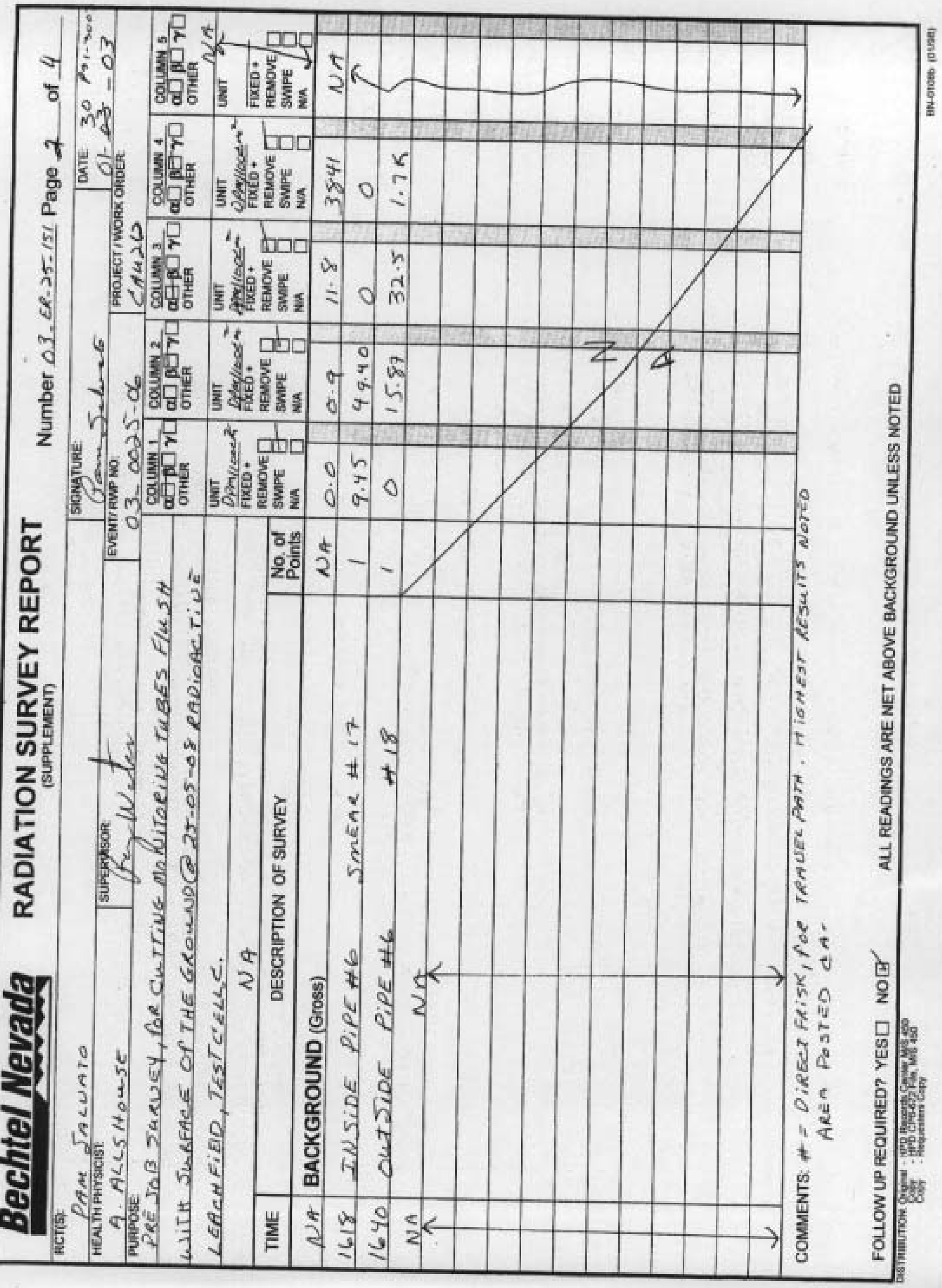




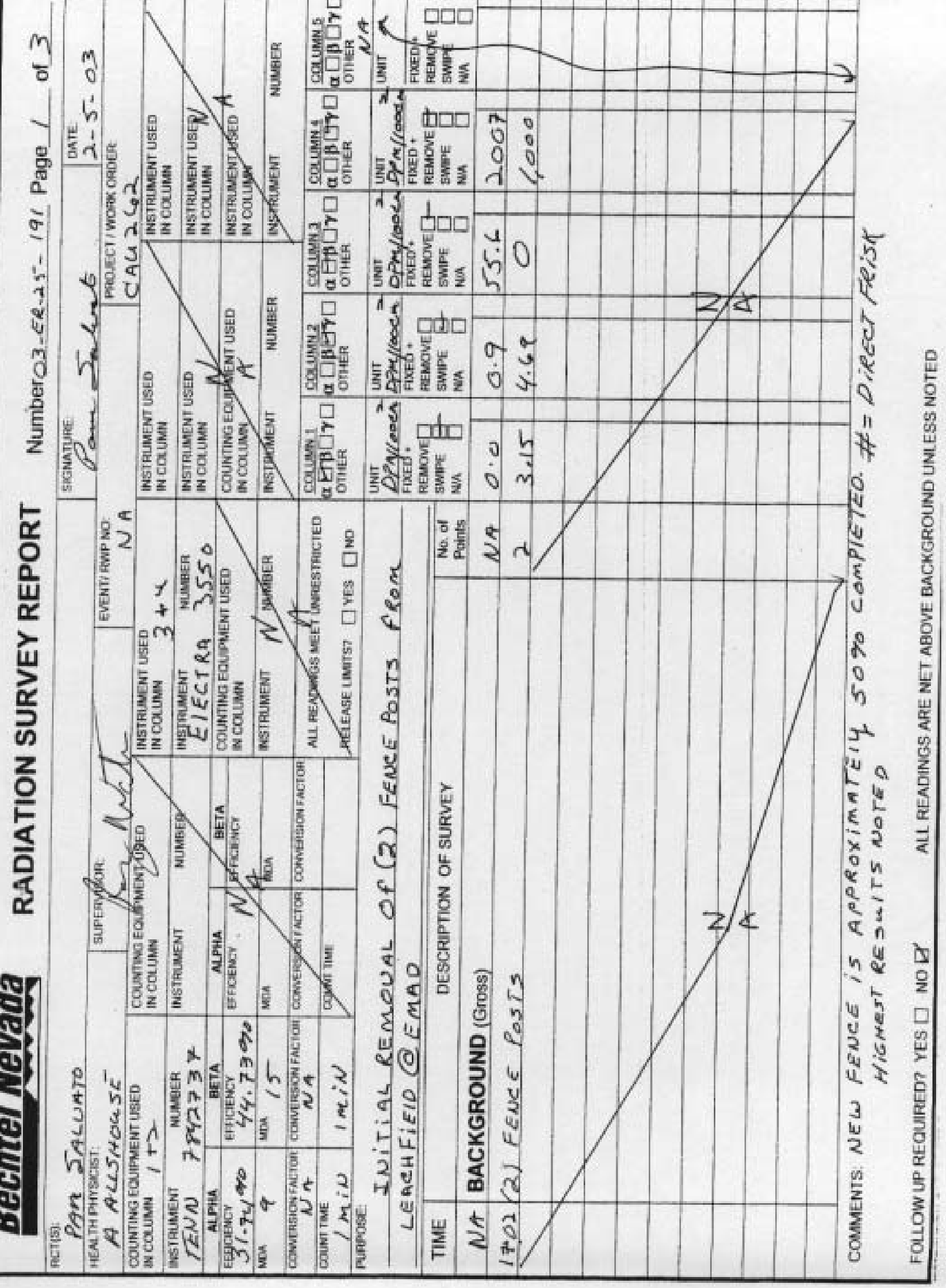




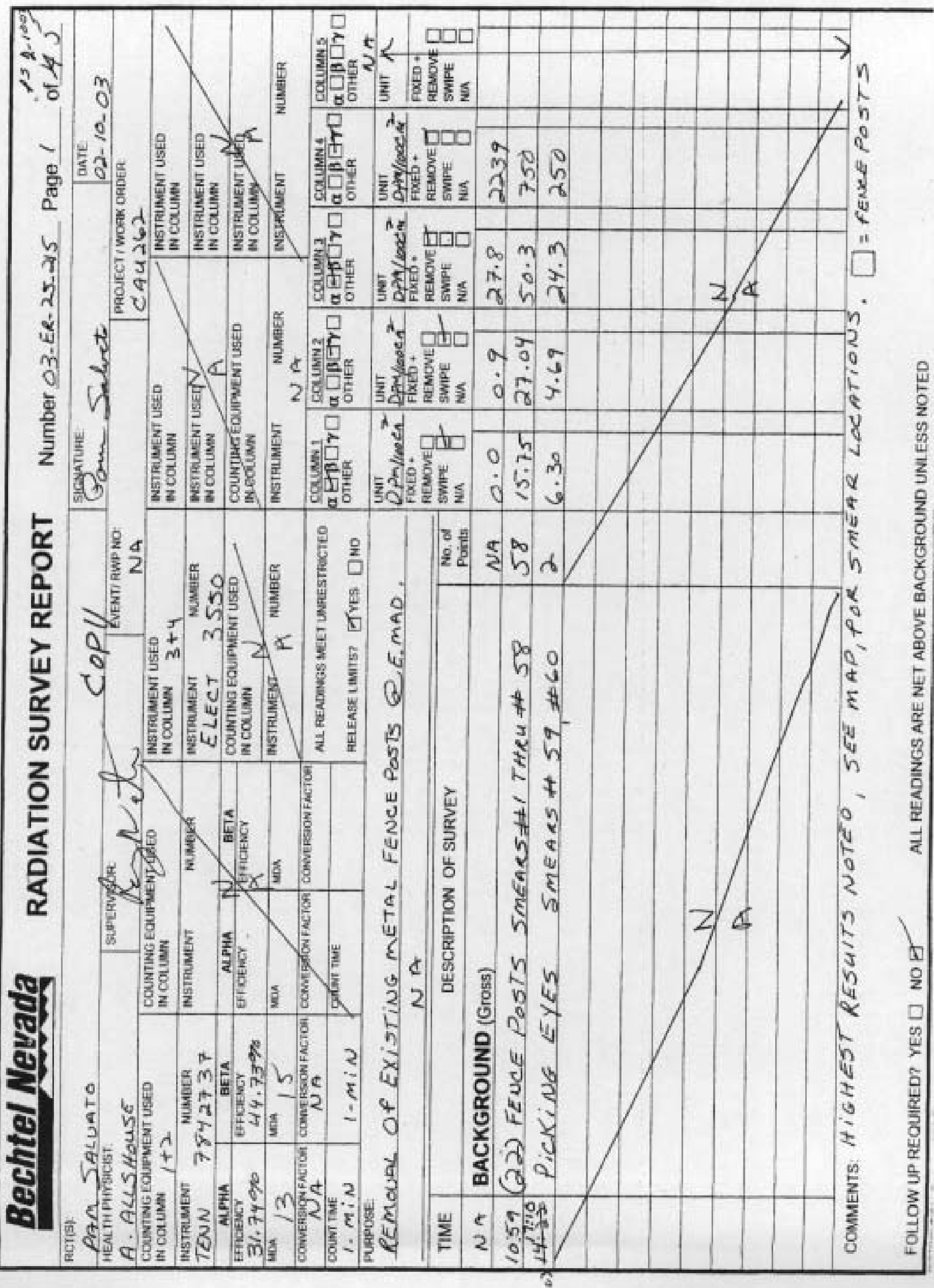




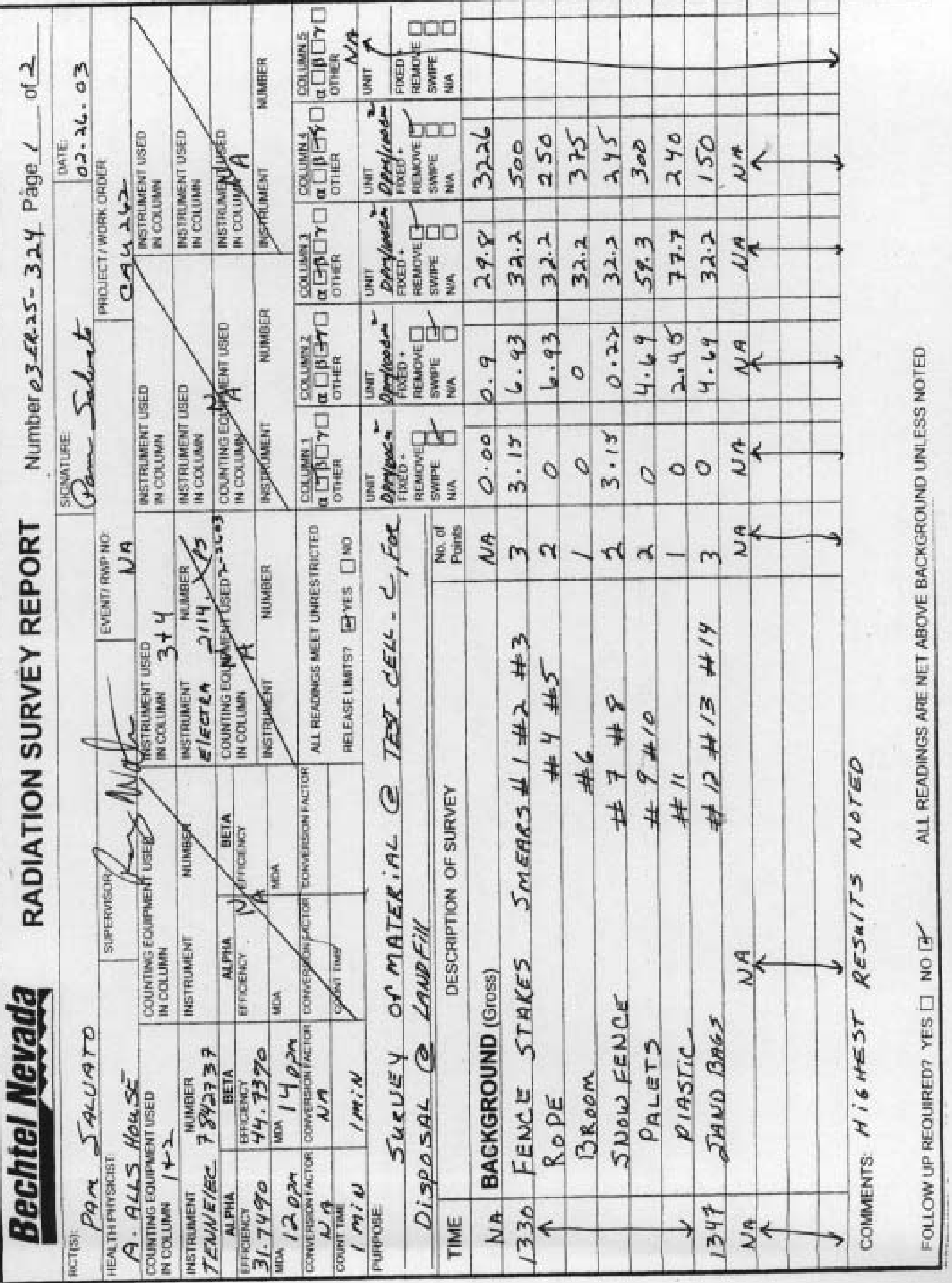




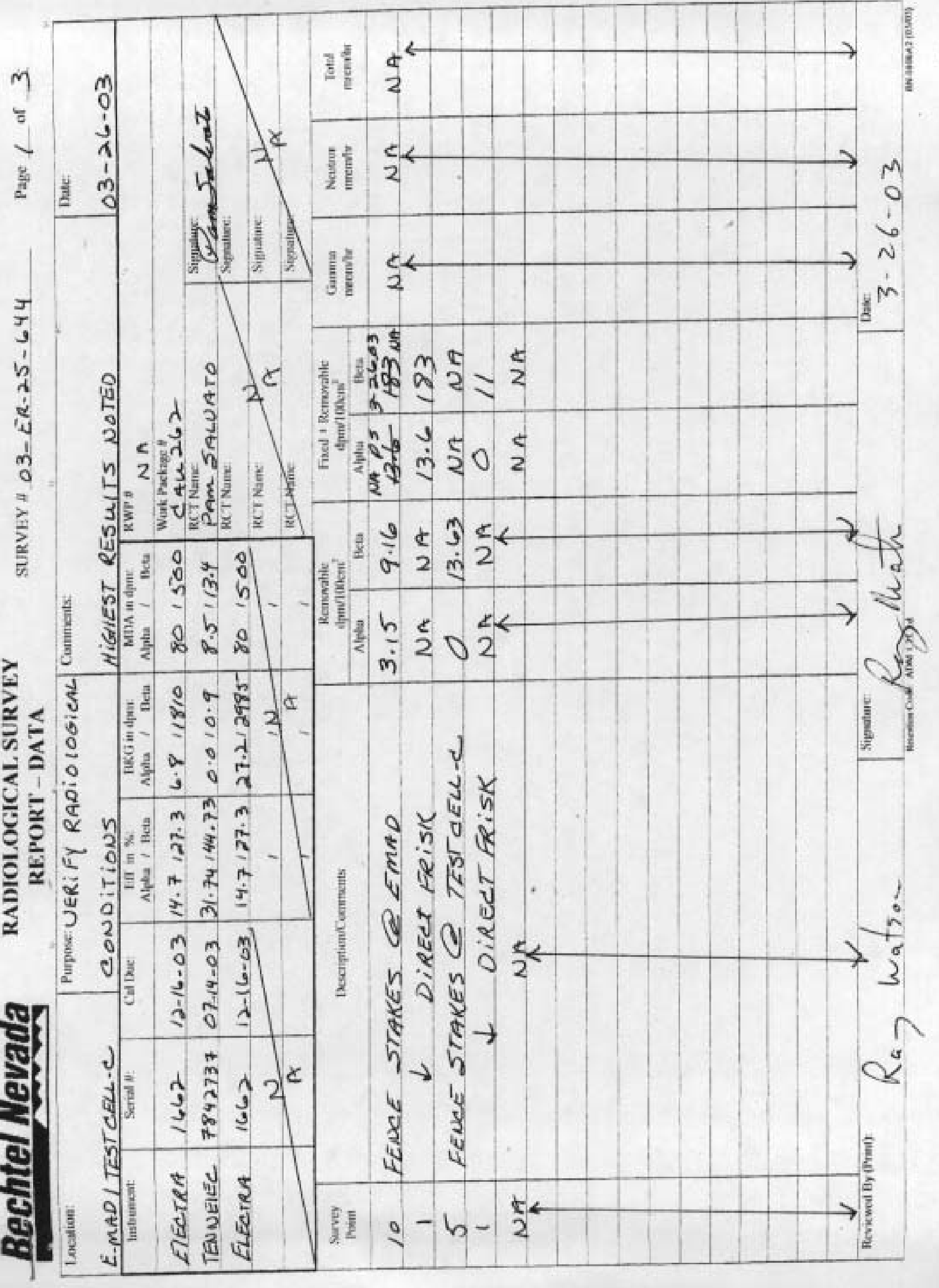


CLOSURE RE PORT - CAU 262

Section: Appendix D

Revision : 1

Date: July 2003

THIS PAGE INTENTIONALLY LEFT BLANK 


\section{APPENDIX E}

\section{WASTE DISPOSITION DOCUMENTATION}


CLOSURE RE PORT - CAU 262

Section: Appendix E

Revision : 1

Date: July 2003

THIS PAGE INTENTIONALLY LEFT BLANK 
For waste characterization, approval, andior assistance, contact Solid Waste Operation (SWO) at 5-7898.

\section{REQUIRED: WASTE GENERATOR INFORMATION}

(This form is for rollofis, dump trucks, and other ansite disposal of materials.)

Waste Generator: Dan Toblason

Phone Number: $\underline{5-6169}$

Location / Origin: Area 25, CAU-262

Waste Category: (check one)

Waste Type:

(check one)

$\square$ NTS

$\square$ Non-Putreadiblo

$\square$ Commercial

$\square$ Putresclble

$\square$ Asbestos Containing Material

X] Industrie

Pollution Prevention Category: (check one)

X] Emironmental management

X] FFACO-onsita

WAC Exoeptian

Pollution Prevention Category: (check one)

Method of Characterization: (check one)

[X] Clean-Up

$\square$ FFACO-Othite

Hatoric DOENN

Prohibited Waste
at all three NTS Iandfills:

X. Samping \& Anatysis

$\square$ Defense Projocts

Radiosctive waste; RCRA wastes; Hazarbous waste; Free liquids, PCAs above TSCA regulatory levele, and Medical

Additional Prohlbited Waste Sewgge Sudge; Animal carcasses, Wet garbege (foed wasle); and Friable astestos

at the Area 9 U10e Landfill:

\section{REQUIRED: WASTE CONTENTS ALLOWABLE WASTES}

Check aff aliowable wastes that are contained within this load:

NOTE: Waste diaposed at the Area 6 Hydrocarbon Landfil must have come into contact with petroleum hydrocatbons or coolants such as: gescline (no benzene, load); fot fuel: desel fuet; lutricants and hydraulics; kerosene, asphatic petroleum tydrocarbons and ettylene gycel.

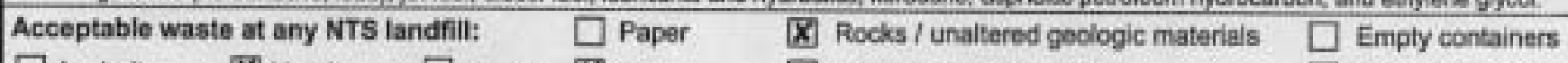
$\square$ Asphalt
X] Metal
$\square$ Wood
[X] Soll
$\square$ Rubbor (oxcluding tires)
[X] Plastic
$\square$ Wire
$\square$ Cable
$\square$ Cloth
$\square$ Insulation (non-Asbestosform)
$\square$ Demolition debris

Manulactured ilems: (swamp coclers, fumiture, rugs, carpet, electronic components, PPE, etc.)

Additional waste accepted at the Area 23 Mercury Landfill: $\square$ Office waste $\square$ Food Waste $\square$ Animal Carcasses

$\square$ Asbestos: $\square$ Friable $\square$ Non-Friable (contact SWO if regulated load) Quantity:

Additional waste accepted at the Area 9 U10c Landfill:
$\square$ Non-iriable asbestos
Drained automobiles and military vehicles
$\square$ Light ballasts (contact SWO)
Drained fuel filters (gas 8 diese)
Solid fractions from sandlollwater separators
Hydrocarbons (contact SWO)
Deconned Underground and Above Ground

Additional waste accepted at the Area 6 Hydrocarbon Landfill:
$[$ X] Septic sludge $\square$ Rags
$\square$ Plants
$\square$ Drained fuel fiters (gas \& diesel)
Crushed non-leme plated oll filters
Sludge from sand/oilwwater separators
PCBs below 50 parts per million REQUIRED: WASTE GENERATOR SIGNATURE

Initials:

Tho above mentioned waste was generated outside of a Controllod Waste Management Area (CWMA) and to the best of my knowledge, does not contain radiological materials.

To the best of my knowledge, the waste described above contains only thos site. I have verified this through the waste chargctorization goethod identifie

prohiblted and allowable waste items. IS F

Print Name: Ql6ethore

Signaturo: $=$ Date: $3-403$

Note: Food waste, office trash and/or animal carcasses are considered not to cor require a radiological clearance.

Radiation Survey Release for Waste Disposal RCT Initials

$\square$ This containerticad is tree of extemal radisective contamination.

This contanerilogd is exaept from survey dae to process knowledge and chigh.

This containerfoed is free of radiosctire

$\square$ contamination batade on radicanalysin.

sovaruke $=2$ okrt 3-403 oimeravis

\section{SWO USE ONLY}

Load Woight (net from scale or estimate):

Signature of Certifier: 


\section{Bechtel Nevada NTS Landfill Load Verification \\ (Waste dofinitions are avaliabio on page 2)}

\begin{tabular}{llllll}
\hline SWO USE (Circle One Area) AREA & $\times$ & 6 & 9 & LANDFILL
\end{tabular}

For waste characterization, approval, andior assistance, contact Solid Waste Operation (SWO) at 5-7898.

REQUIRED: WASTE GENERATOR INFORMATION

Waste Generator, Dan Toblason

(This form is for rollofis, dump trucks, and other ansite disposal of materials.)

Location/Origin: Area 25, CAL-262

\begin{tabular}{|c|c|c|c|}
\hline Waste Category: (check one) & $\square$ Commercial & X. Industrial & \\
\hline Waste Type: & $\square$ Putrescible & [X] FFACO-onsite & $\square$ WAC Excoption \\
\hline (check one) $\square$ Non-Putrescblo & $\square$ Asbestas Containing Material & $\square$ FFACO-affate & $\square$ Historic DOENV \\
\hline Pollution Prevention Category: (check one) & [X] Envirenmental maragement & $\square$ Defense Projects & \\
\hline Pollution Prevention Category: (check cne) & [X] Clean-Up & Routine & \\
\hline Method of Charactorization: (check one) & X. Sampling \& Analyais & $\square$ Process Knowledge & Contents \\
\hline
\end{tabular}

Prohibited Waste Racicactive wasta; RCRA wagte; Hazardous wasta, Free liquids, PCEs above TSCA regulatory levela-, and Medical

at all three NTS landfills: wastes (needles, sharps, bloody dothing). Additional Prohibited Waste Sewage Sudge; Arimal carcasses, Wet garbage (food waste) and Friable anbestcos
at the Area 9 U10c Landfill:

\section{REQUIRED: WASTE CONTENTS ALLOWABLE WASTES}

Check all allowable wastes that are contained within this load:

NOTE: Waste disposed at the Avea 6 Hydrocarbon Landfil must hava come into contact with petroleum kydrocarbons or coclants such as: gasoline (no benzane. lesdk; jet fuel; diesal fuel; hubricants and hydraulics; kerosane; asphatic petraleum hydrocarban and ethylens gaveol
Acceptable waste at any NTS landfill:
$\square$ Asphalt $\square$ Motal $\square$ wood
$\square$ Paper
X. Rocks / unaltered geologic materials
$\square$ Emply containers
X. Plastic
$\square$ Cable
[X] Soll
$\square$ Rubber (excluding tires)
$\square$ Insulation (non-Asbestosform)
$\square$ Demalition debris

$\square$ Manufactured items: (swamp coolers, furniture, rugs, carpet, electronic components, PPE, etr.)

Additional waste accepted at the Aroa 23 Mercury Landfili: $\square$ Omice waste $\square$ Food Waste $\square$ Animal Carcasses Asbestos: $\square$ Friable $\square$ Non-Friable (contact SWO if regulated load) Quantity:

Additional waste accepted at the Area 9 U10e Landfill:
$\square$ Nan-friable asbestos
Light ballasts (contact SwO)
$\square$ Hydrocarbons (ocntact SWO)
Drained automobles and military vehicles
Drained fuel filters (gas 8 diese)
Solid fractions from sand/oilwater separalors
$\square$ Deconned Underground and Above Ground
Tanks

Additional waste accepted at the Area 6 Hydrocarbon Landfill:
$\bigotimes$ Septic sludge $\square$ Rags
Plants
Drained fuel filters (gas 8 diesel)
Sludge from sandjolWwater separators
Crushed non-teme plated cil filters

Initials: REQUIRED: WASTE GENERATOR SIGNATURE

(Ni initialed, no redilological clearance is necessary.)

The above mentioned waste was generated outside of a Controlled Waste Management Area (CWMA) and to the best of my knowlodge, does not contain radiological materials.

To the best of my knowledge, the waste described above contains only thoi sife. I have verified this through the waste charactarization method identifle

prohlbited and allowable waste itoms.

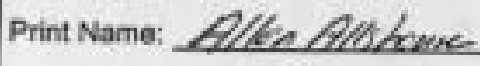

Signature: Date: $23 / 63$

Note: Food waste, office trash and/or animal carcasses are considered not to co: require a radiological clearance.

\section{SWO USE ONLY}

Load Weight (net from scale or estimate):

Signature of Certifier:

Radiation Survey Releaso for Wasto Disposal RCT Iniliala

V This containerilosd is free of extemal radioactive contamination.

This coetanentogd is exempt trem osvery due to process ichowisc ge and erigin.

This contalnenlosd is free of radiosectre

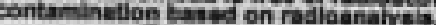

sacentums: DATER 2405 mestores 


\section{Bechtel Nevada NTS Landfill Load Verification}

(Waste definitions are available on page 2)

\section{SWO USE (Circle One Area) AREA \\ 23 \\ 6 \\ $x$ \\ LANDFILL}

For waste characterization, approval, andior assistance, contact Solid Waste Operation (SWO) at 5-7898.

REQUIRED: WASTE GENERATOR INFORMATION

Waste Generator: Dan Toblason

(This form is for rolloffs, dump trucks, and other onsite disposial of materials.)

Location / Origin: Area 25, CAU-262

\begin{tabular}{|c|c|c|c|}
\hline Waste Category: (check one) & \multirow{2}{*}{$\begin{array}{l}\square \text { Commercial } \\
\square \text { Putrescible }\end{array}$} & \multicolumn{2}{|l|}{ X] Industrial } \\
\hline Waste Type: & & X] FFACO-ansite & $\square$ WaC Exeption \\
\hline (check one) $\square$ Non-Putrescble & $\square$ Asbestos Containing Matorial & $\square$ FFACO-ottuite & $\square$ Histaric DOENW \\
\hline Pollution Prevention Category: (check one) & X] Envronmental manapement & $\square$ Defense Projects & \\
\hline Pollution Prevention Category: (check one) & $X$ Clean-Up & Routine & \\
\hline Method of Characterization: (check one) & X] Sampling \& Analysis & $\square$ Procass Knowledge & Contants \\
\hline
\end{tabular}

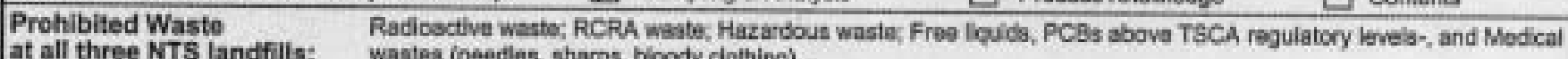

at all three NTS landfills: $\quad$ wastes (needles, sharps, bloody dothing).

Additional Prohibited Waste Sewage Studge; Animal carcasees, Wet garbago (food wastak, and Friable asbestos at the Area 9 U10e Landfill:

\section{REQUIRED: WASTE CONTENTS ALLOWABLE WASTES \\ Check all allowable wastes that are contained within this foad:}

NOTE: Waste dispesed at the Ava 6 Hydrocarbon Landfil must have come into contact with potroleum hydrocarbons or cociants such as: gasoline (no benzene, lead): jet funi: diesal fuel; hubricants and bydraulics; kerosene; asphatic petroleum lydrocarbon; and ettylene gyool

Acceptable waste at any NTS landfilt: $\quad \square$ Paper $\quad \square$ Rocks / unaltered geologic materials $\quad \nabla$ Empty containers
$\square$ Asphalt
Q Metal
Q1 Wood
$\square$ Soll
$\square$ Rubbar (excluding fires)
$\square$ Demolition debris

XI Plastic $\quad$ Wire

$\square$ Cable $\square$ Cloth

$\square$ Insulation (non-Asbestostorm)

$\square$ Manufactured items: (swamp coolers, furniture, rugs, carpet, electronic components, PPE, etc.)

Additional waste accepted at the Area 23 Mercury Landfll: $\square$ Office waste $\square$ Food Waste $\square$ Animal Carcasses Asbestos: $\square$ Friable $\square$ Non-Friable (contact SWO if regulated load) Quantity:
Additional waste accepted at the Area 9 U10e Landfill:
$\square$ Non-friable asbestos
$\square$ Light ballasts (contact SWO)
Hydrocarbons (contact SWO)
$\square$ Drained automobiles and military vehicles
Drained fuel filters (gas 8 diesel)

Solid fractions from sand/oil/water separators

$\square$ Deconned Underground and Above Ground

Additional waste accepted at the Area 6 Hydrocarbon Landfill:
$\square$ Septic studge $\square$ Rags
Dplants
$\square$ Drained fuel filters (gas \& diesel)
$\square$ sludge from sand/oilwater separators
Crushed non-ferme plated oil filters
PCBs below 50 parts per million

Tanks

Cement \& concrete

REQUIRED: WASTE GENER
Initials:___ (Winitialed, no radiological clearance is nocessary. REQUIRED: WASTE GENERATOR SIGNATURE

The above mentioned waste was generated outside of a Controlled Waste Management Area (CWMA) and to the best of my knowledge, does not contain radiological materials.

To the best of my knowledge, the waste described above contains only those $n$ site. I have verified this through the waste characterization mothod identified ai prohibited and allowable waste items.

DANuEr S. ToDifson

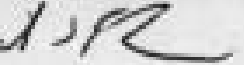

Print Name: Allenifylore

Signature Date: 3423

Note: Food waste, office trash and/or animal carcasses are considered not to contair require a radiological clearance.

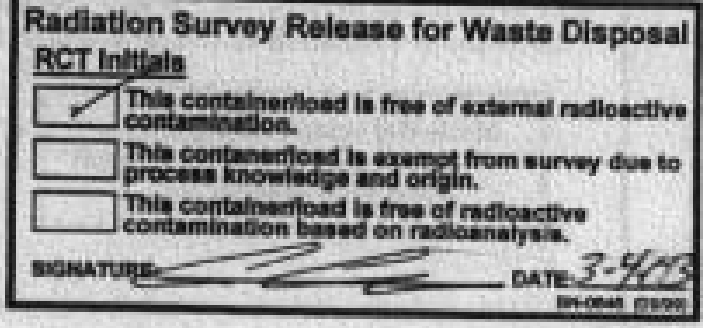

\section{SWO USE ONLY}

Load Weight (net from scale or estimate):

Signature of Certifier: 


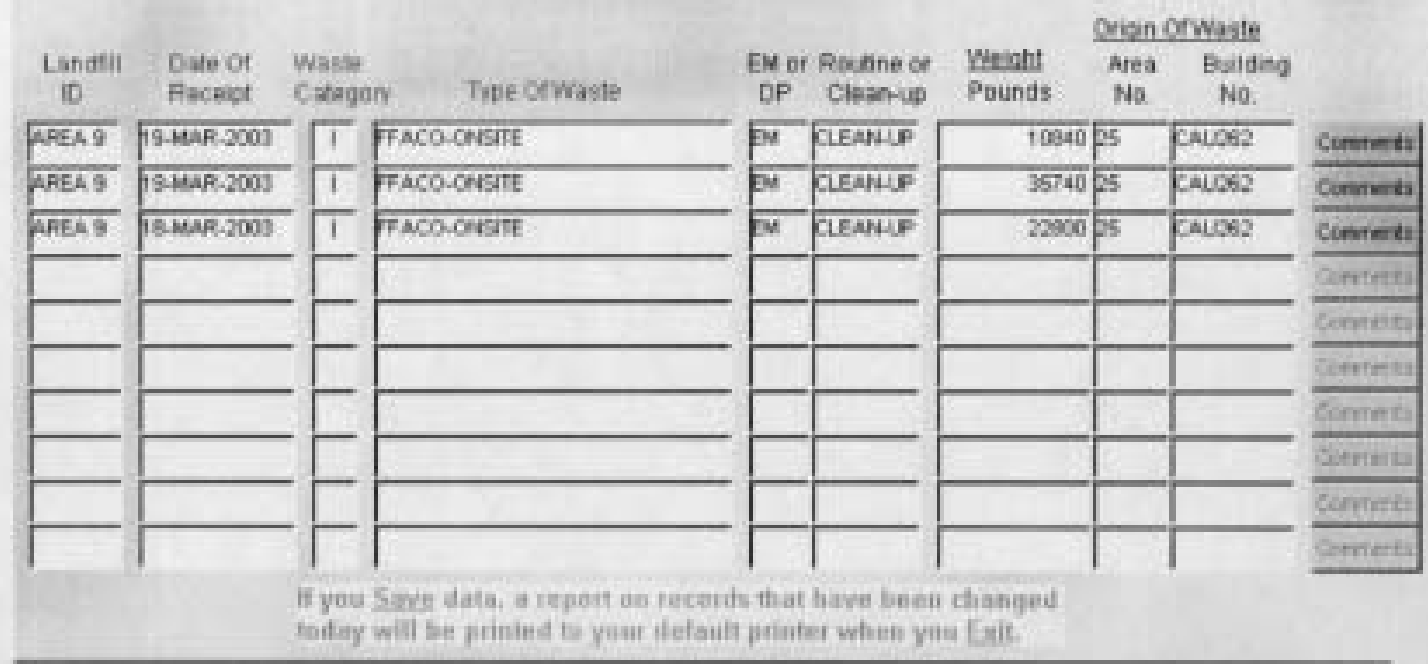

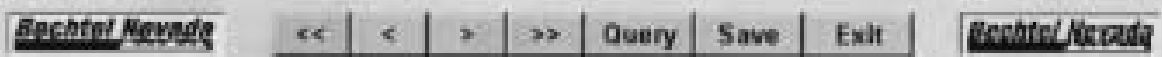




\begin{tabular}{|c|c|c|c|c|c|c|c|c|c|}
\hline \multirow{3}{*}{$\begin{array}{l}\text { Landeli } \\
10\end{array}$} & \multirow{3}{*}{$\begin{array}{l}\text { Date of } \\
\text { Precest }\end{array}$} & \multirow{3}{*}{$\begin{array}{l}\text { Wasse } \\
\text { Categar }\end{array}$} & \multirow[b]{3}{*}{ The of waste } & \multirow{3}{*}{$\begin{array}{c}\text { EN at } \\
\text { DP }\end{array}$} & \multirow[b]{2}{*}{ Rowane or } & \multicolumn{3}{|c|}{ Originorwaste } & \\
\hline & & & & & & Weight & Area & Baldivg & \\
\hline & & & & & Clearuse & Pounds & $\mathrm{Na}$ & No. & \\
\hline AFEA 8 & $13-10 a k-2003$ & $T$ & FFCO-OWSTE & Bt & CLEALEF & 39500 & 25 & Patb82 & Contents \\
\hline AFEA 6 & 1.WWAR 2001 & $T$ & FACO-ONGTE & Br & CLENLAP & 30920 & 3 & pelo52 & Converts \\
\hline किEन & $72 \mathrm{Wu}-2005$ & $T$ & TACOCOCSTE & M & EEAT:F & 35000 & 5 & Euto62 & Comernets \\
\hline कहली & $72 \mathrm{~mW} .2003$ & $T$ & ThCOCAESTE & 5M & FENAT & अश10 & 25 & PUSK2 & comert: \\
\hline कEA 6 & 72040.2003 & $T$ & PACO-OCEIt & E & EEANG & 35000 & 25 & - & Comerta \\
\hline MEA6 & 1294\%:2005 & $T$ & TACO-OtESTE & En & EEANTF & 42930 & 25 & EMSES & Cominers \\
\hline MeA 6 & 2.40\%:3003 & $T$ & TACO-CWEITE & $M$ & मE्थज्ञ & 9150 & 5 & Cus62 & Converte \\
\hline WeA 6 & 7.46\%.2003 & $T$ & Faco-chant & $M$ & व्NWOP & 75000 & 3 & PUS62 & Conenerts \\
\hline NeA 6 & 1.4ur.:003 & $T$ & Faco-chart & BM & DENASF & 40000 & 5 & Puass & comert: \\
\hline $\cos 6$ & 1.:Wh:3003 & $T$ & FACO-Chate & EM & Feaks & 39350 & 25 & pelosi2 & Comerta \\
\hline & & $\begin{array}{l}11 \text { yow } \\
\text { bifays }\end{array}$ & & mis & & $\begin{array}{l}\text { thasyed } \\
\text { Crit. }\end{array}$ & & & \\
\hline
\end{tabular}

\begin{tabular}{|c|c|c|c|c|c|}
\hline Bechtel Reveds & & & $\ll$ & & , \\
\hline
\end{tabular}




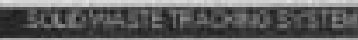

\begin{tabular}{|c|c|c|c|c|c|c|c|c|c|}
\hline \multirow[b]{2}{*}{$\begin{array}{l}\text { Landhi } \\
\text { iD }\end{array}$} & \multirow[b]{2}{*}{$\begin{array}{l}\text { Dite of } \\
\text { Receigh }\end{array}$} & \multirow[b]{2}{*}{$\begin{array}{l}\text { Waste } \\
\text { Categor }\end{array}$} & \multirow[b]{2}{*}{ Thee Orwaste } & \multirow[b]{2}{*}{$\begin{array}{l}\text { EMor } \\
\text { Ce }\end{array}$} & \multirow[b]{2}{*}{$\begin{array}{l}\text { Routine of } \\
\text { Clean-up }\end{array}$} & \multicolumn{3}{|c|}{ Qnamorwese } & \\
\hline & & & & & & $\begin{array}{l}\text { Weirst } \\
\text { Pounds }\end{array}$ & $\begin{array}{l}\text { Nes } \\
\text { No. }\end{array}$ & $\begin{array}{l}\text { Oulding } \\
\text { No. }\end{array}$ & \\
\hline TREQ 5 & T1 MEAR2000 & $T$ & FACOOAGIE & FM & CEAN- & 35000 & 5 & Perref2 & Cotmerts: \\
\hline RFEA 6 & PT-MUAR-2003 & $T$ & FAOOLONGTE & EM & CLEANDF? & 35000 & 25 & Catrat2 & Cotnerts \\
\hline PREA 6 & T) MUA:2000 & $T$ & FMCOONGIE & FM & ALANG & 36760 & 5 & CNIZ62 & Cotnerta \\
\hline CEEA 5 & 1.4062000 & $T$ & FACOCNGIt & FM & PENG & 3000 & 5 & CUIDE & Commerts \\
\hline Gera 6 & powh.200 & $T$ & pricolowste & FM & RESisto & 24500 & 5 & END62 & Connerts \\
\hline Mexs & 10 man:200s & 1 & Faco-ovante & Fu & PENGO & 30500 & 5 & एNore & Connerts \\
\hline arese & 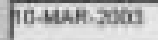 & $T$ & FACOCACIIE & Fu & PFAN- & 300 & 5 & CU182 & Connets: \\
\hline $4 \cos 6$ & 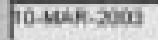 & 7 & FACO-OWEIt: & E & $\overline{P+2 N-B)}$ & 20200 & 5 & स्थक्6 & Connerta \\
\hline hes 5 & 10.42/.2003 & $T$ & Faco-ongit: & Fi & peasts & उत्र000 & 5 & CAIDE2 & Commerts \\
\hline$\sqrt{\text { atise }}$ & 10-mah.2003 & $T$ & TACOCIEIII & $F$ & ReWNAP & 340 & 5 & CAIDE2 & Connert= \\
\hline
\end{tabular}

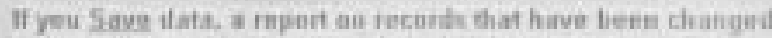

tuday will be printed to your default prinier when you Lxit.

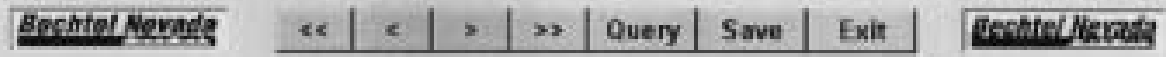




\begin{tabular}{|c|c|c|c|}
\hline$\underset{10}{\text { Langh: }}$ & $\begin{array}{l}\text { Date of } \\
\text { Rateipt }\end{array}$ & $\begin{array}{l}\text { Washt } \\
\text { conegan }\end{array}$ & Twe Gt Waste \\
\hline ARgA & 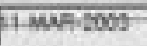 & 1 & FACOF:CHIIE \\
\hline CPSA 6 & T1.4\% 2002. & I & Faco-onstr. \\
\hline abese & Thancous & 4 & PACo-courit \\
\hline ALSE: & $10+401.5000$ & 1 & Facsodell \\
\hline Alests & 10 stchasos & $T$ & 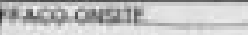 \\
\hline Mese & 10. MWh 2003 & I & PACQ-OFite. \\
\hline Mutes & 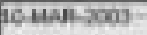 & 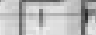 & FAco-onctis- \\
\hline atese & Dowexin & 1 & Focososale \\
\hline MESE & Domatzon & 1 & 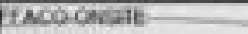 \\
\hline heas 6 & fowar-2003 & $T$ & FAcosongly \\
\hline
\end{tabular}

\begin{tabular}{|c|c|c|c|c|}
\hline \multirow{3}{*}{$\begin{array}{c}\text { EKer } \\
\text { De }\end{array}$} & \multirow{3}{*}{$\begin{array}{l}\text { Roisne of } \\
\text { Clean-up }\end{array}$} & \multirow{3}{*}{$\begin{array}{l}\text { Weight } \\
\text { Pounds }\end{array}$} & \multicolumn{2}{|c|}{ Orian orwasta } \\
\hline & & & Ares & Bulding \\
\hline & & & No. & \\
\hline an & PEWHP & 30000 & 5 & ENOSO2 \\
\hline $\mathrm{su}$ & Fevive. & 2076 & 25 & ENine? \\
\hline M & DENIU & -3600 & ps. & ENibEa: \\
\hline Ba & TEANSS & 24500 & 25 & -2atrin \\
\hline F & DEswas & $\$ 500$ & 15 & CNOBS2 \\
\hline m- & DentuP & 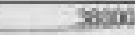 & 56 & pense \\
\hline M & D.NWES & $=\sin 20$ & F5 & 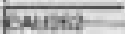 \\
\hline & Fonds & श्रका & s & ENSO \\
\hline 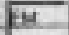 & 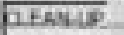 & Mati: & 8 & Funes- \\
\hline & & L. 4006 & $s$ & \\
\hline
\end{tabular}

\section{cenenert} Cumosin Cumets Cinturesta conreds

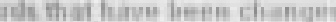
today will be printed to your defauit printer whinn you Luit

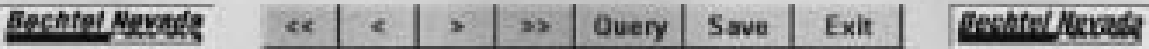




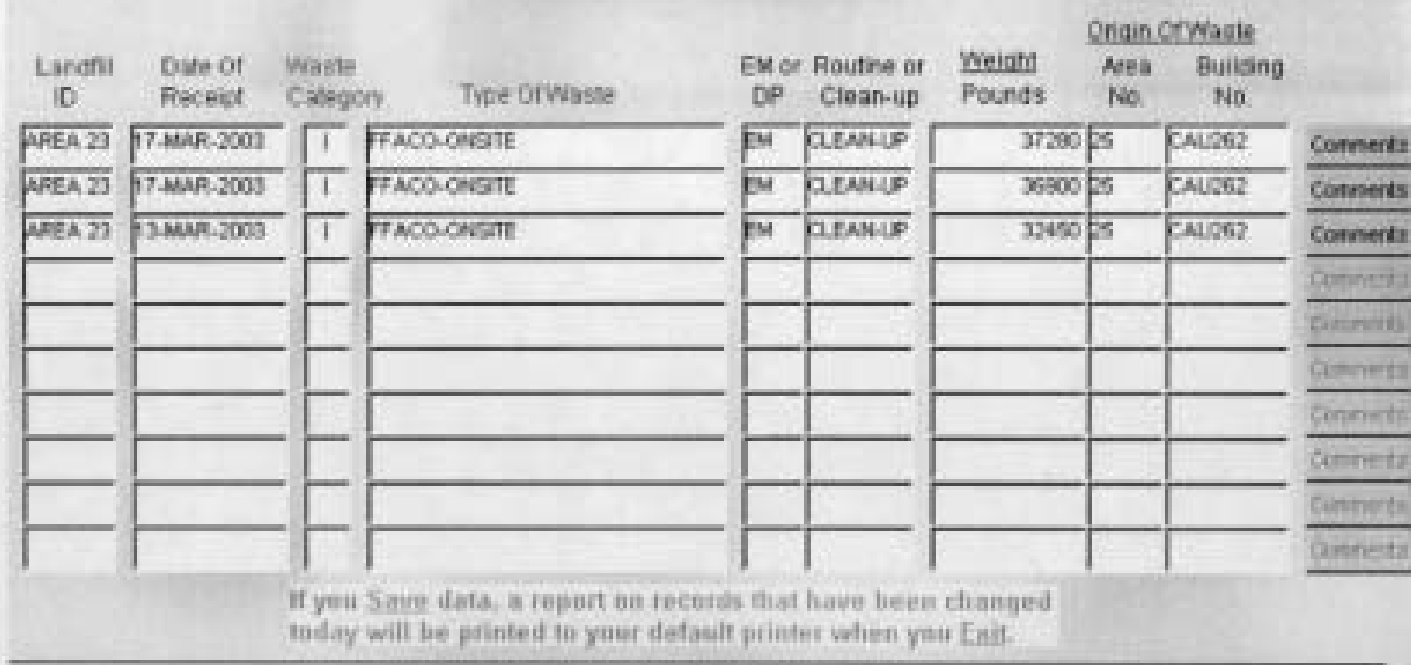

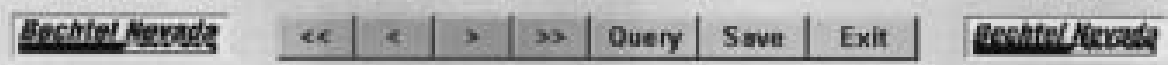




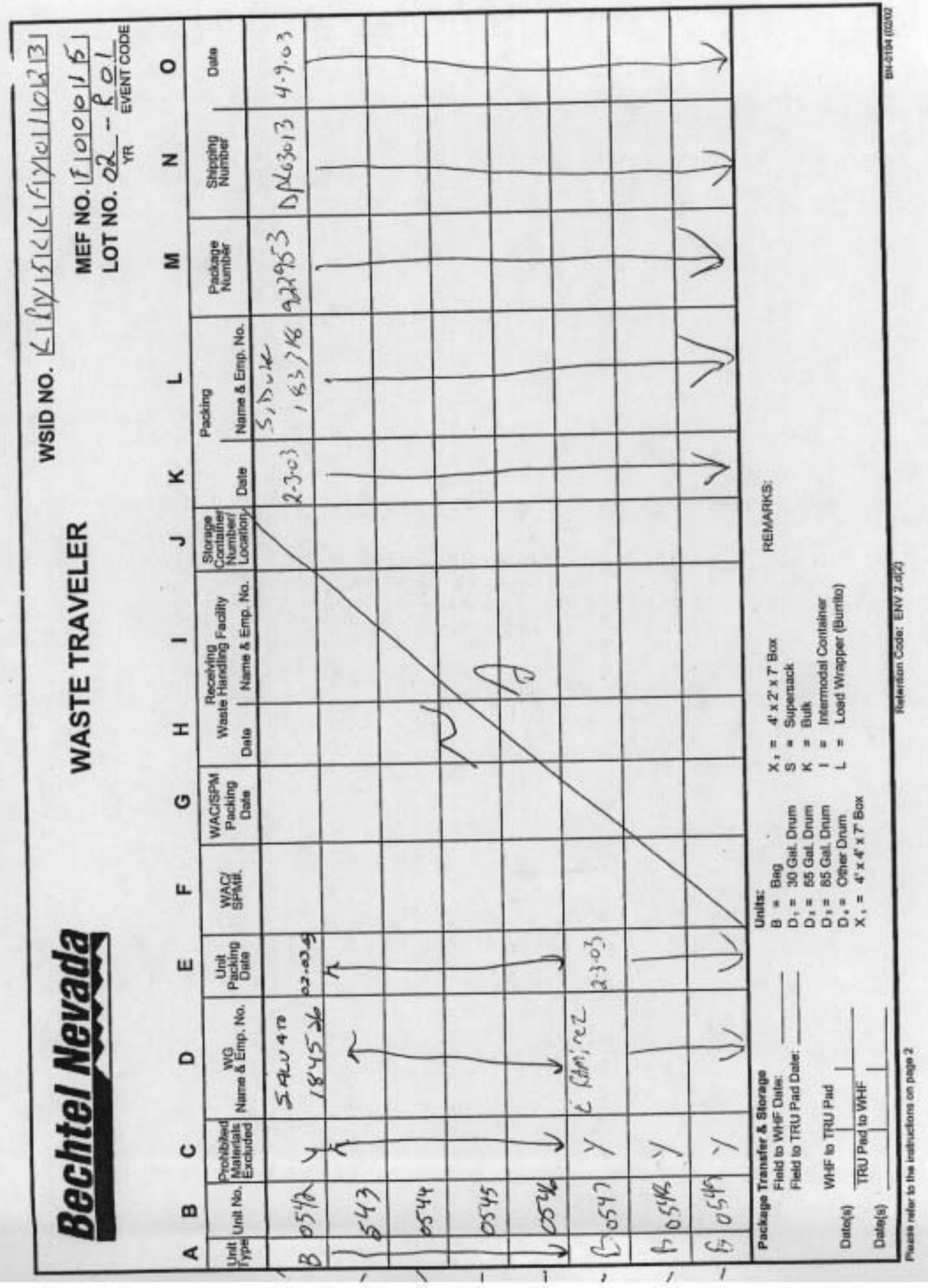




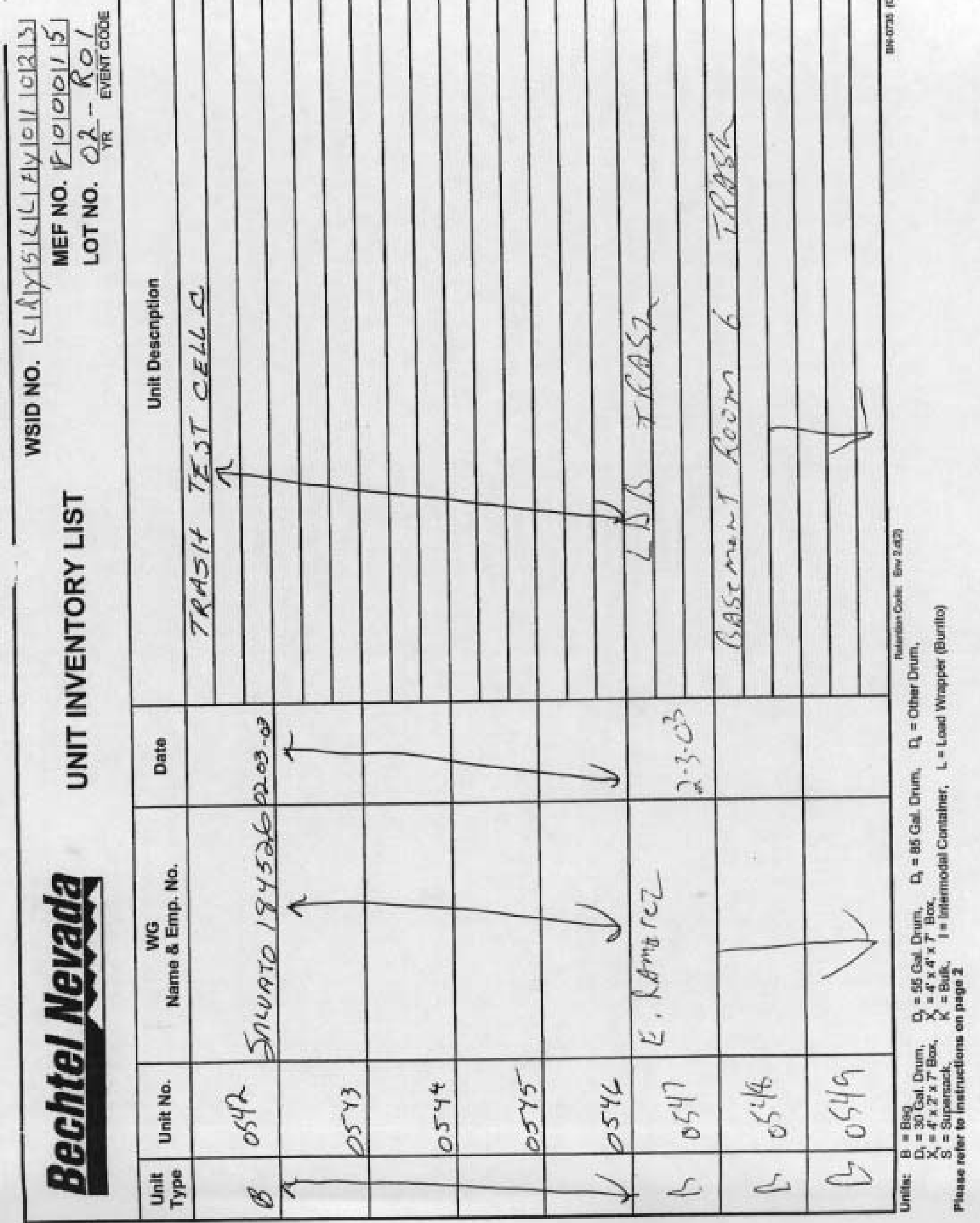




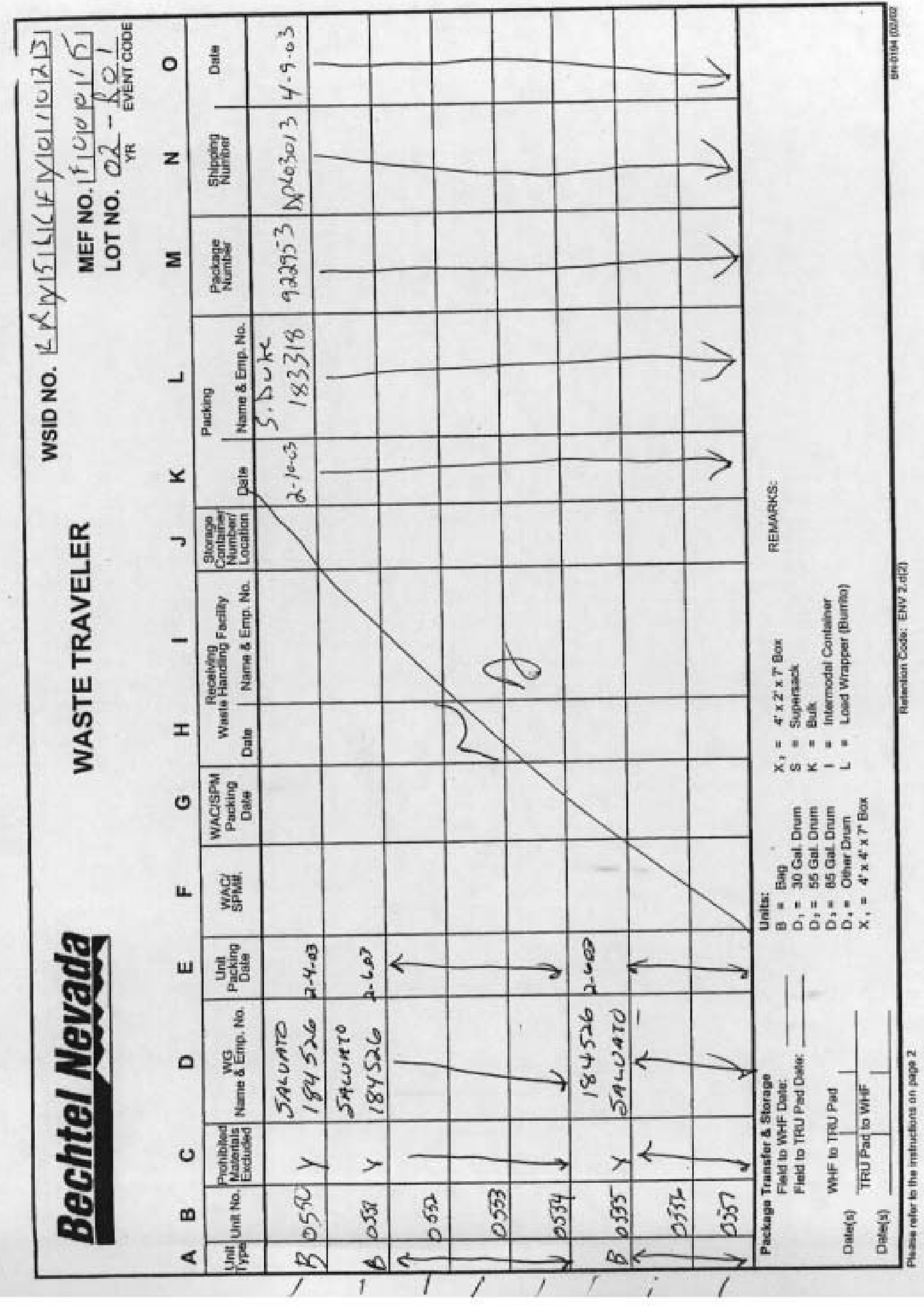




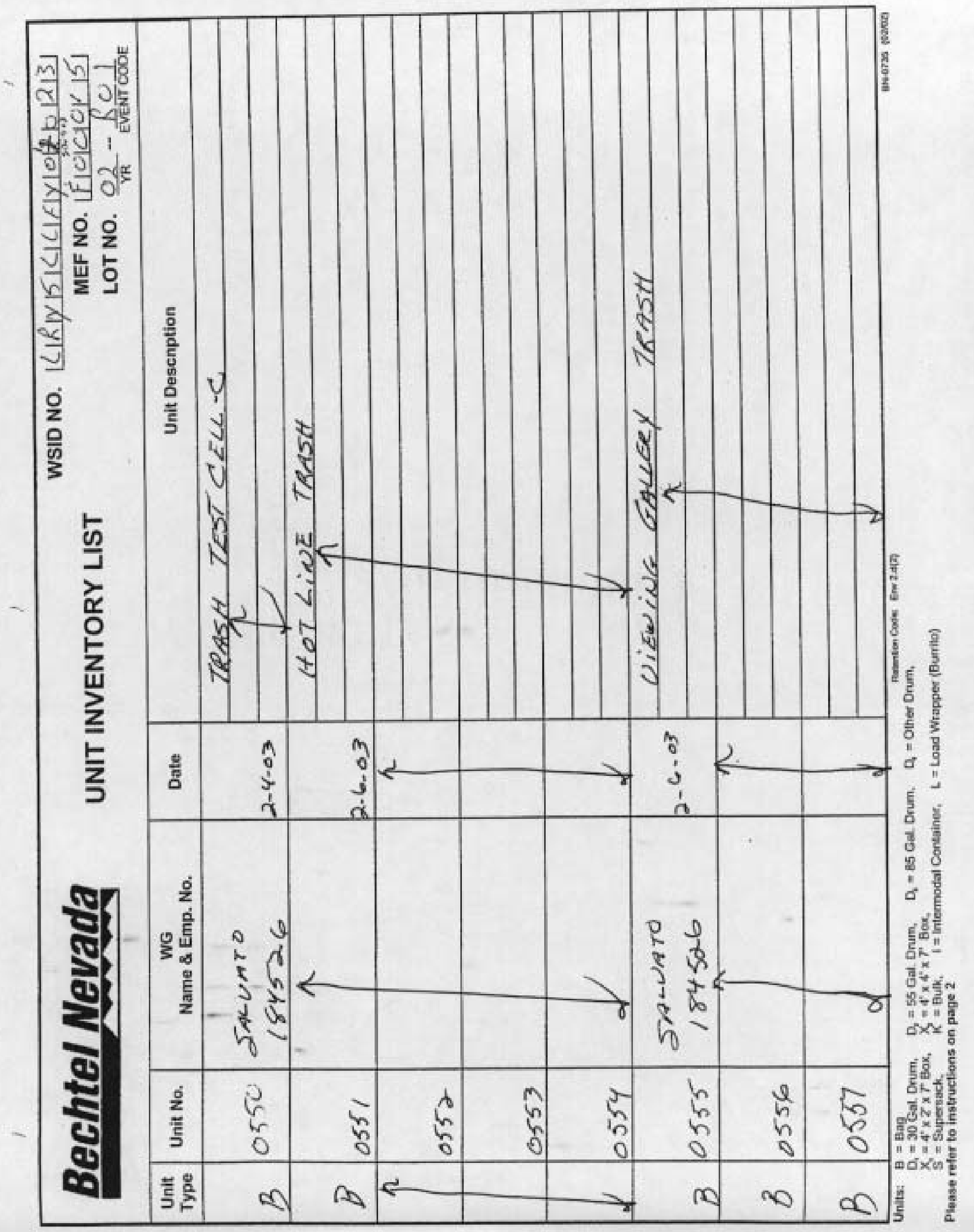


CLOSURE RE PORT - CAU 262

Section: Appendix F

Revision : 1

Date: July 2003

\section{APPENDIX F}

\section{"AS-BUILT" DRAWINGS}


CLOSURE RE PORT - CAU 262

Section: Appendix F

Revision : 1

Date: July 2003

THIS PAGE INTENTIONALLY LEFT BLANK 


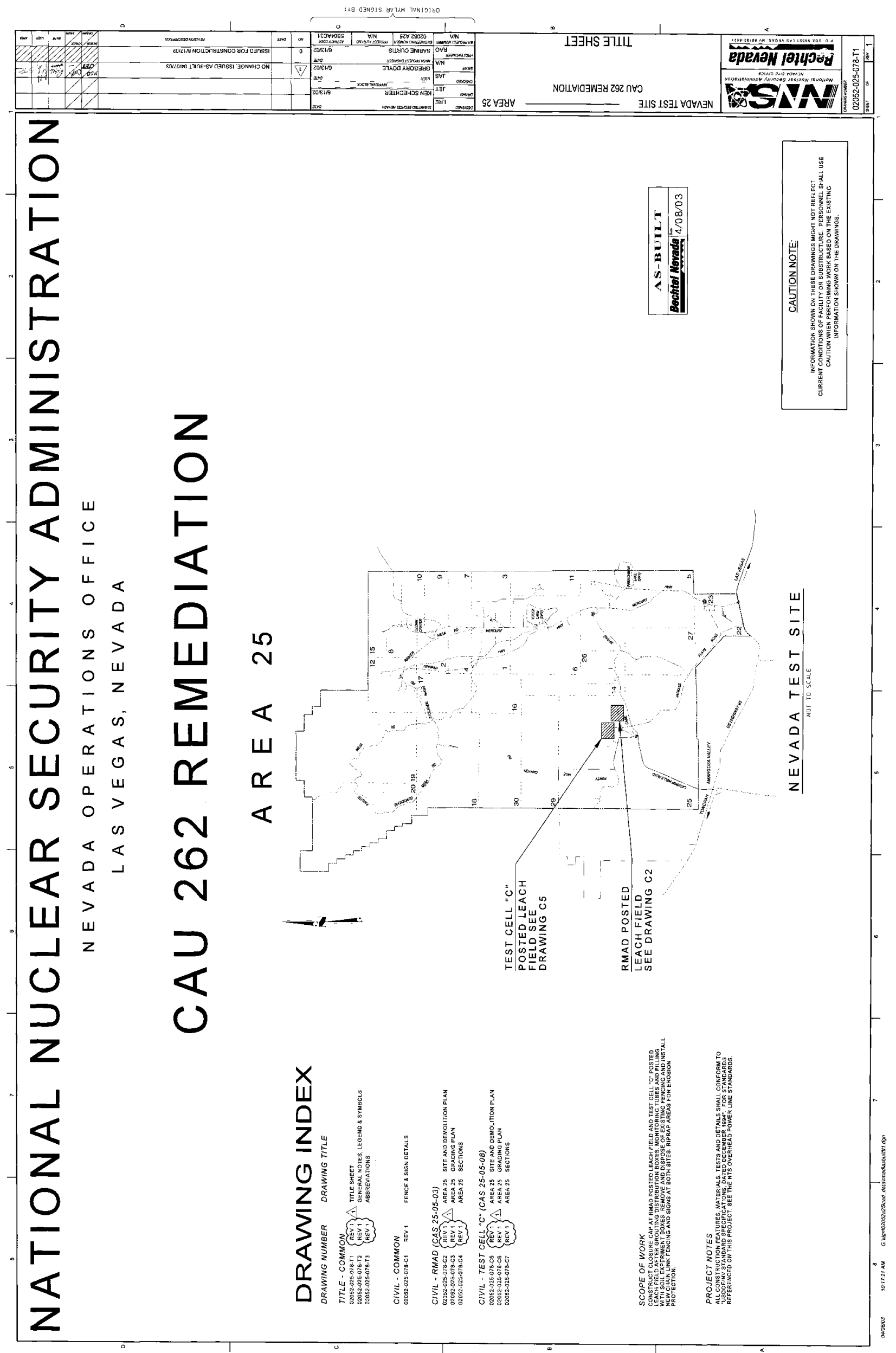




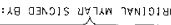

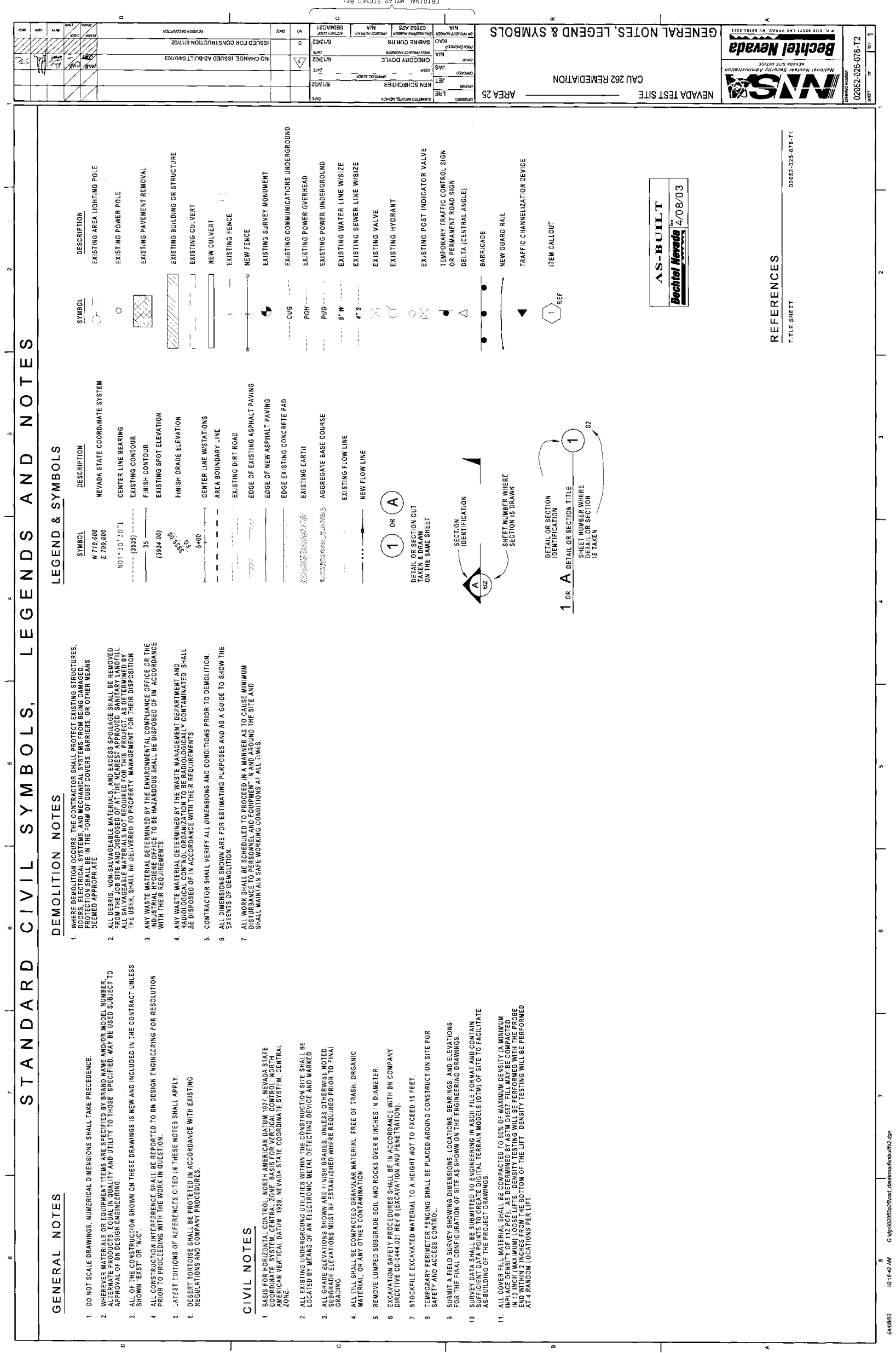




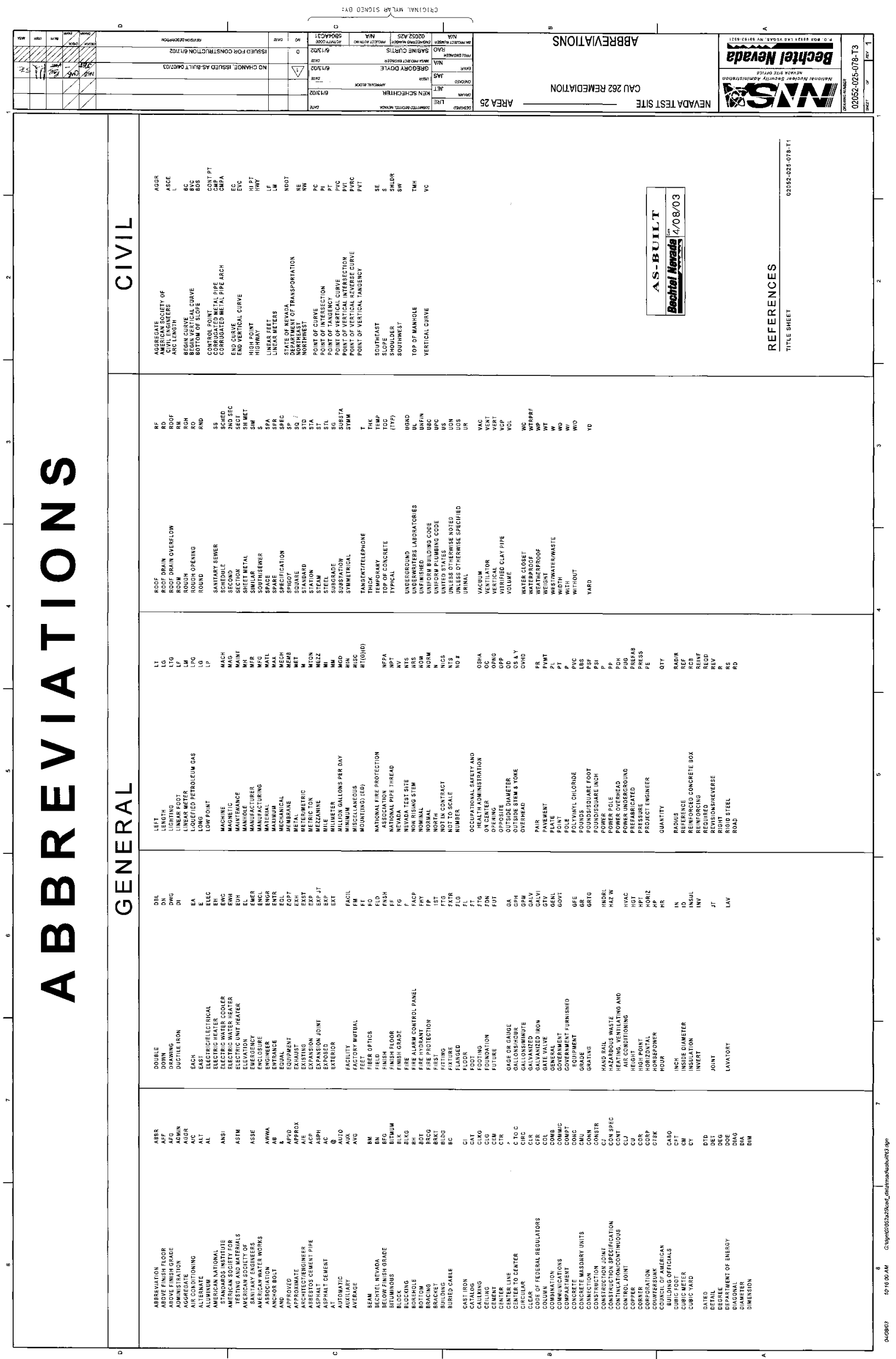




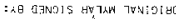

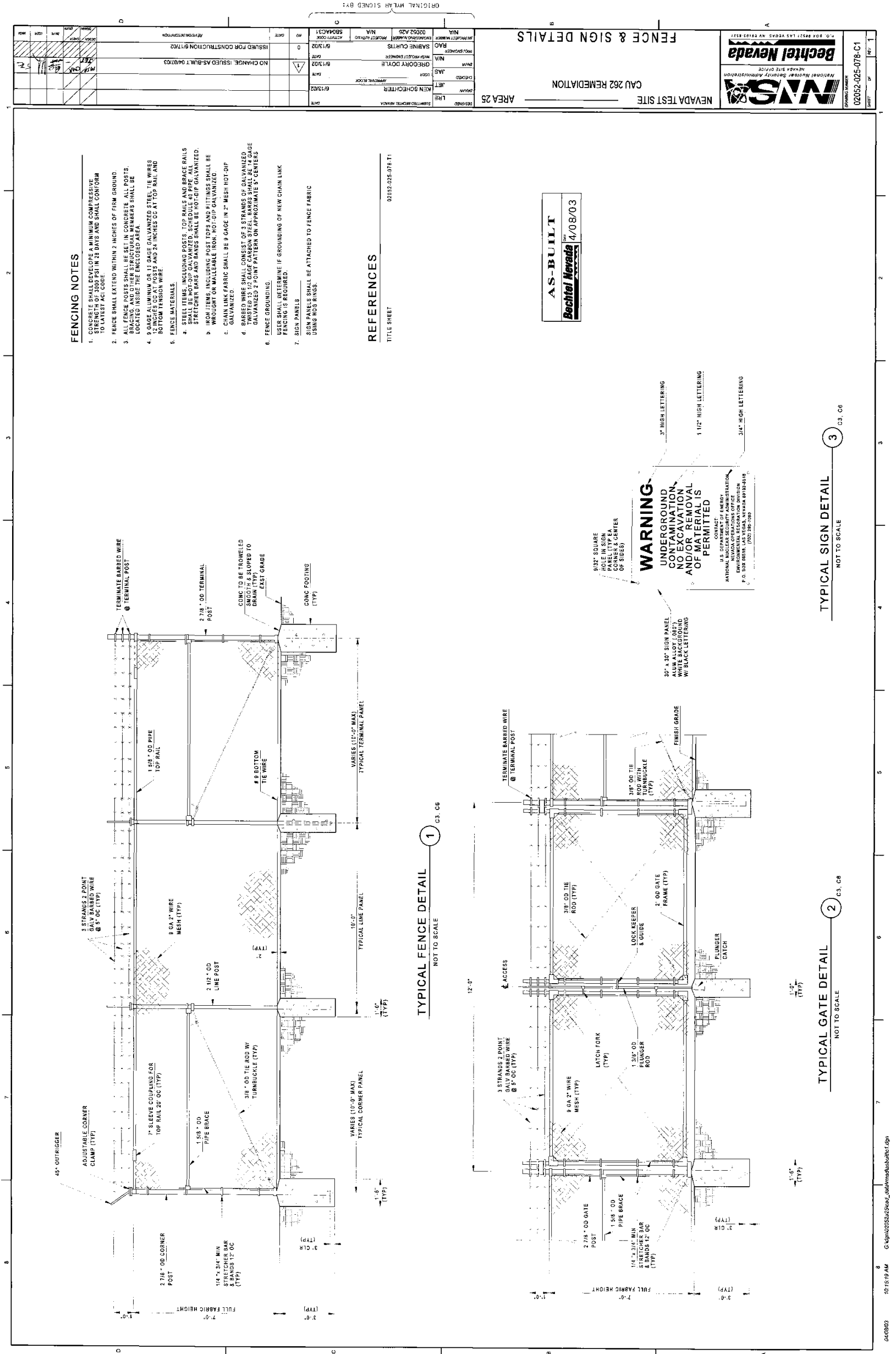




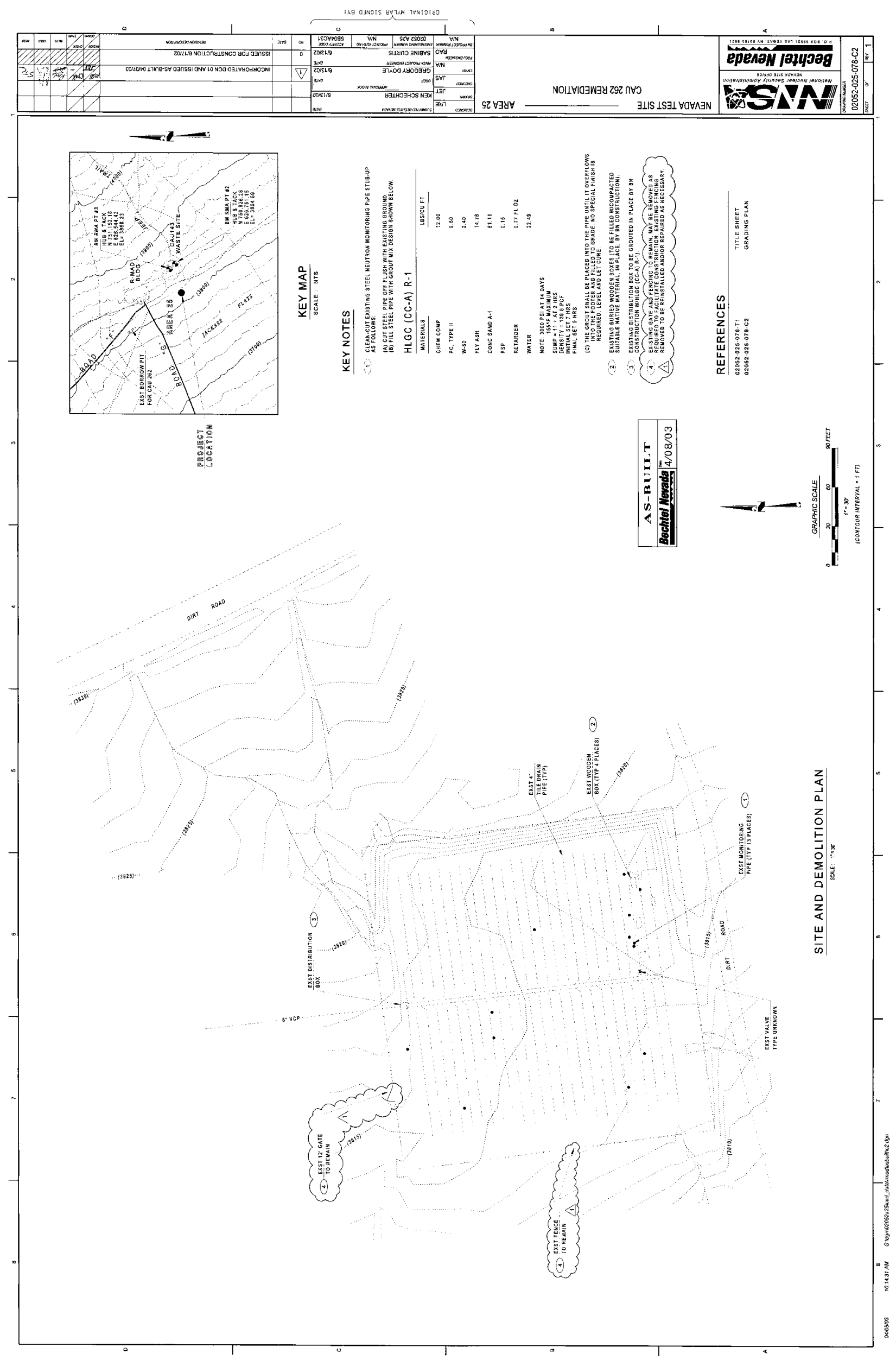




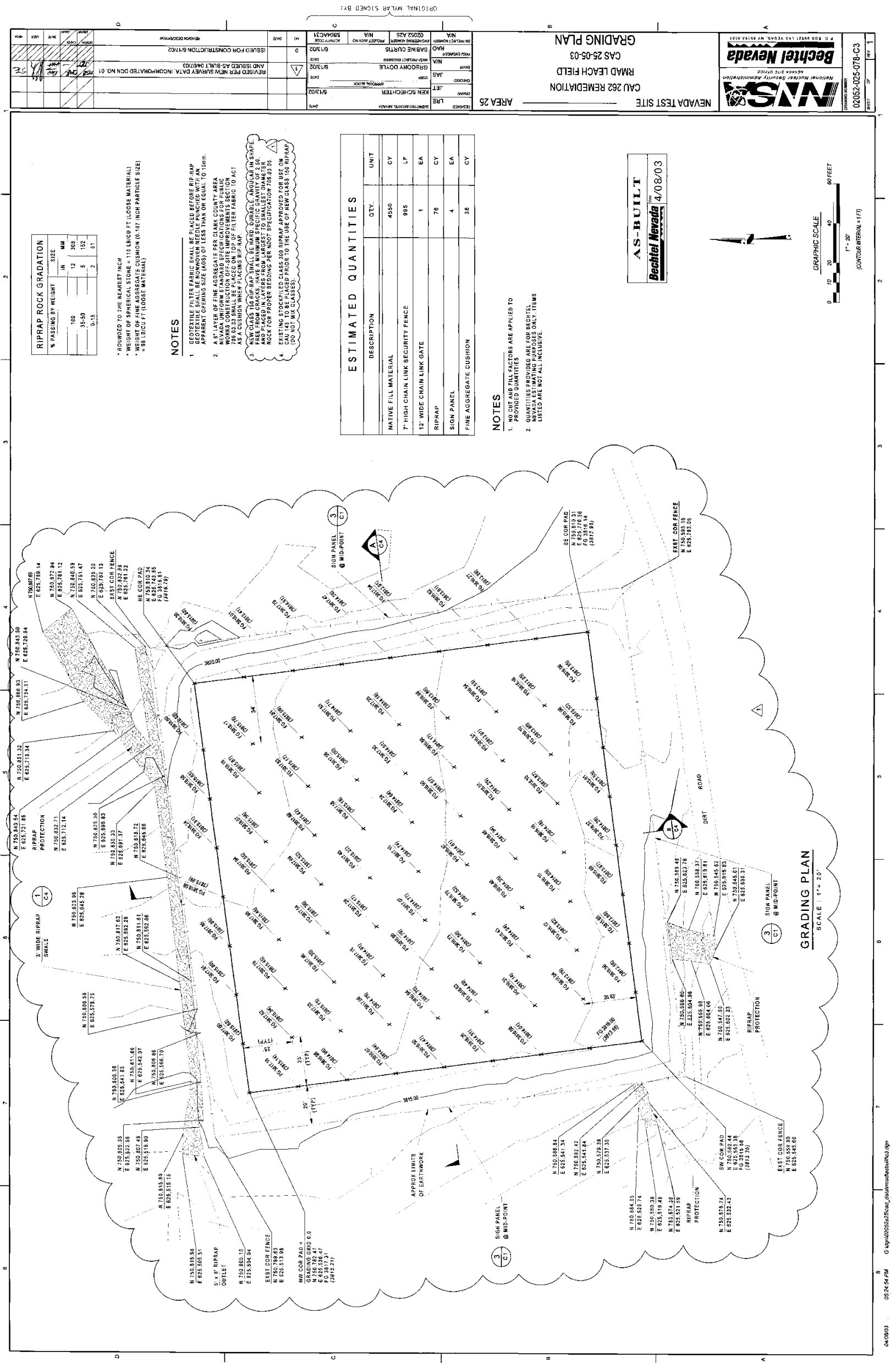




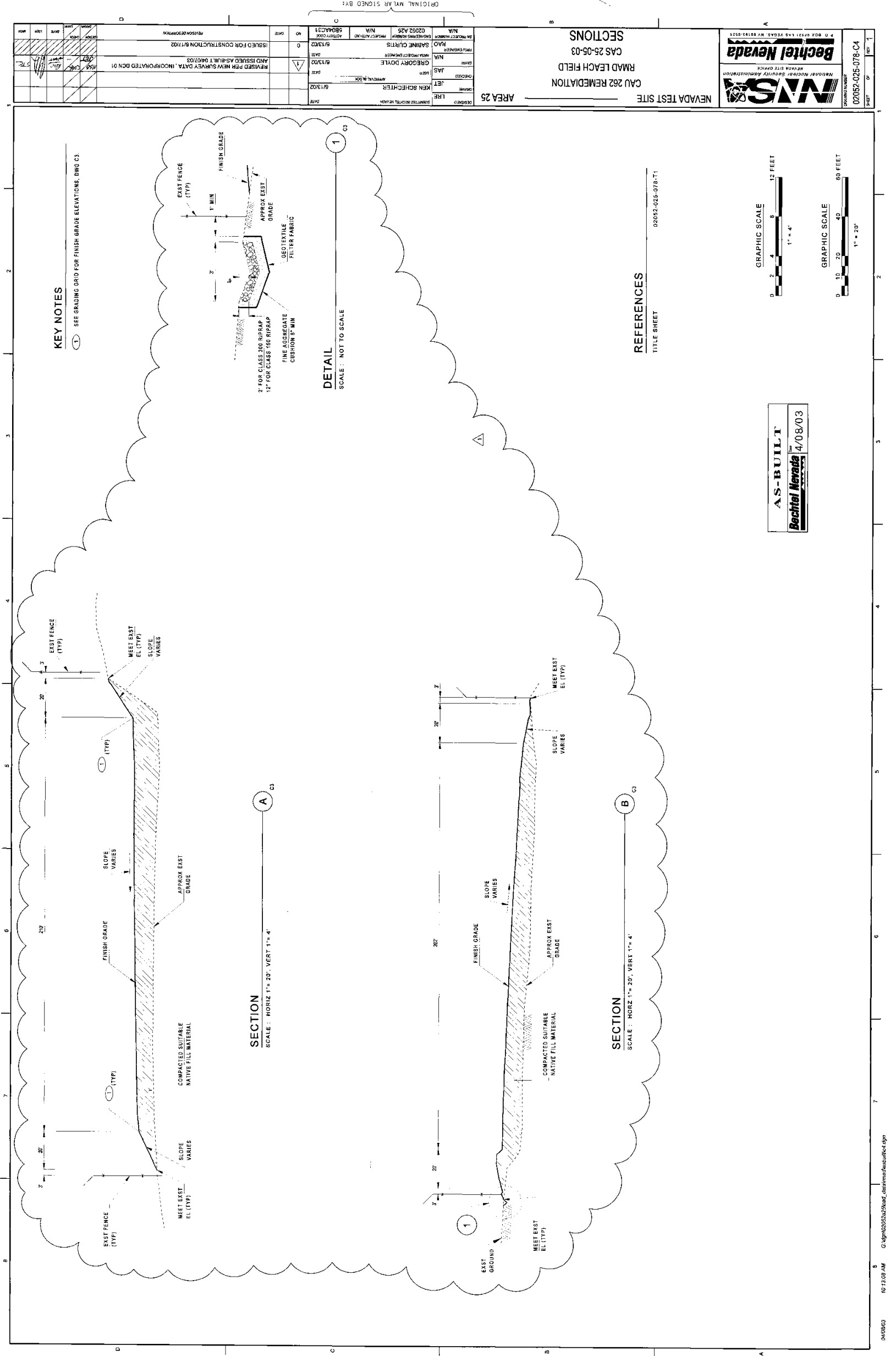




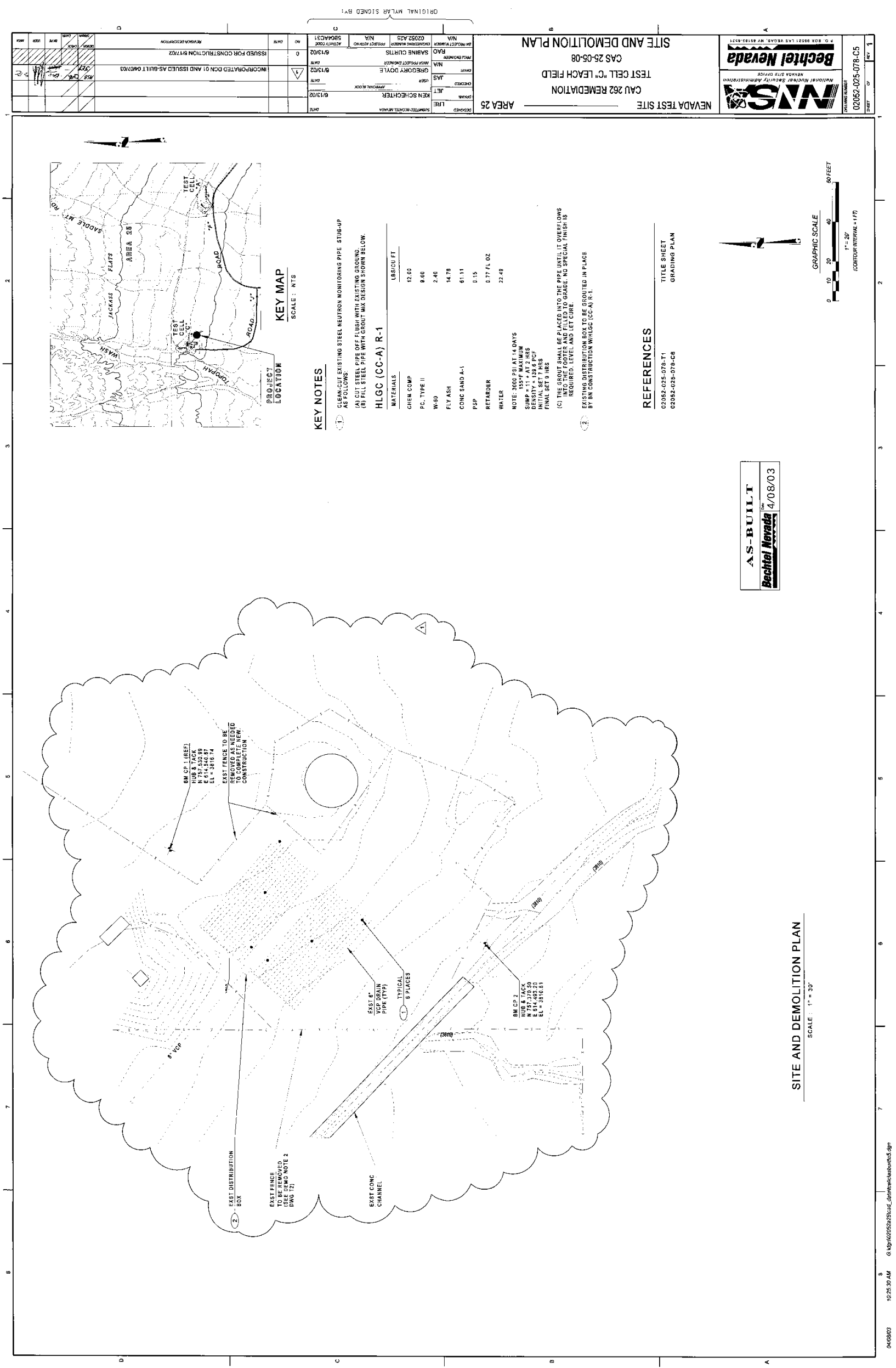




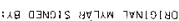
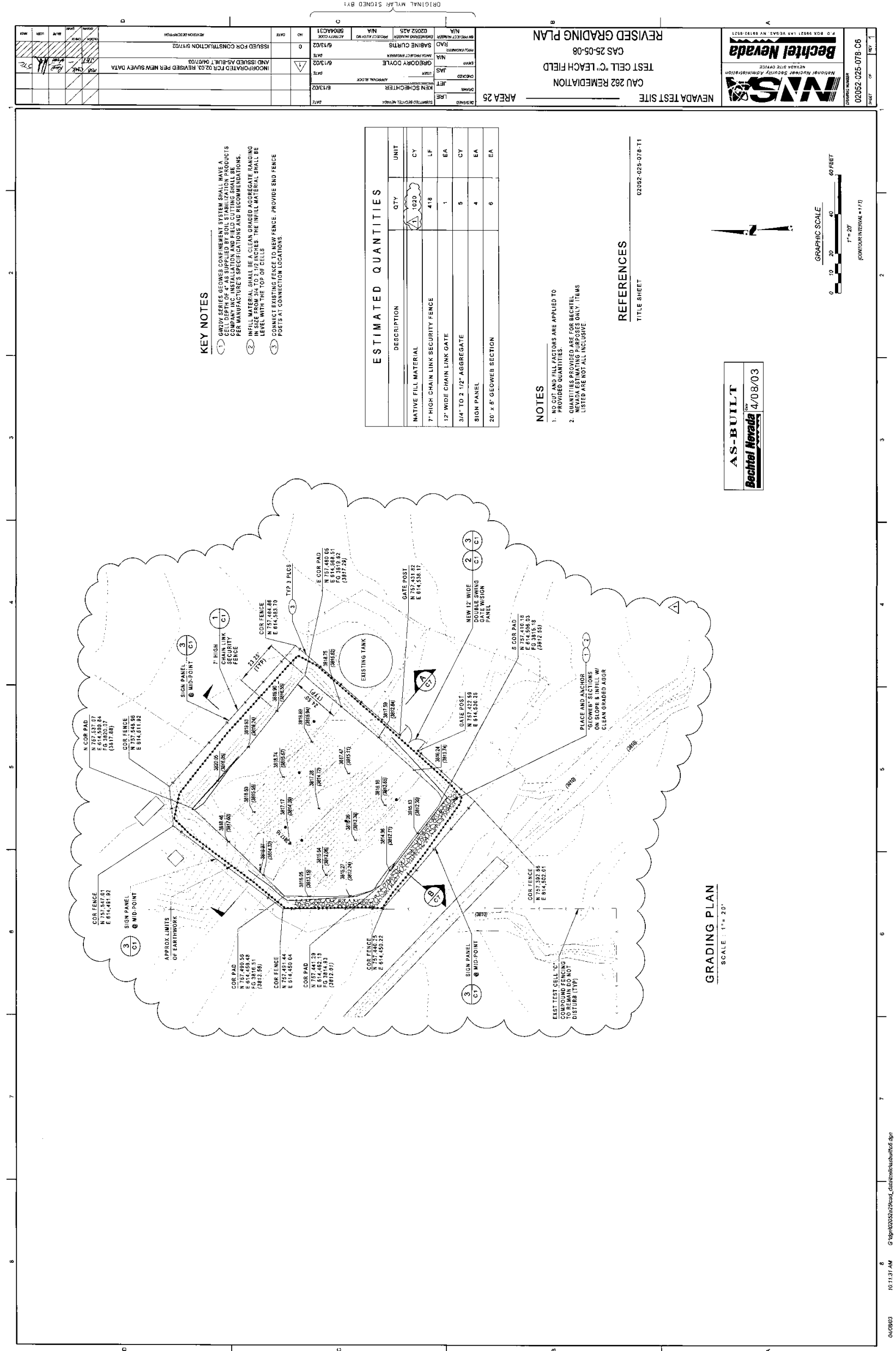


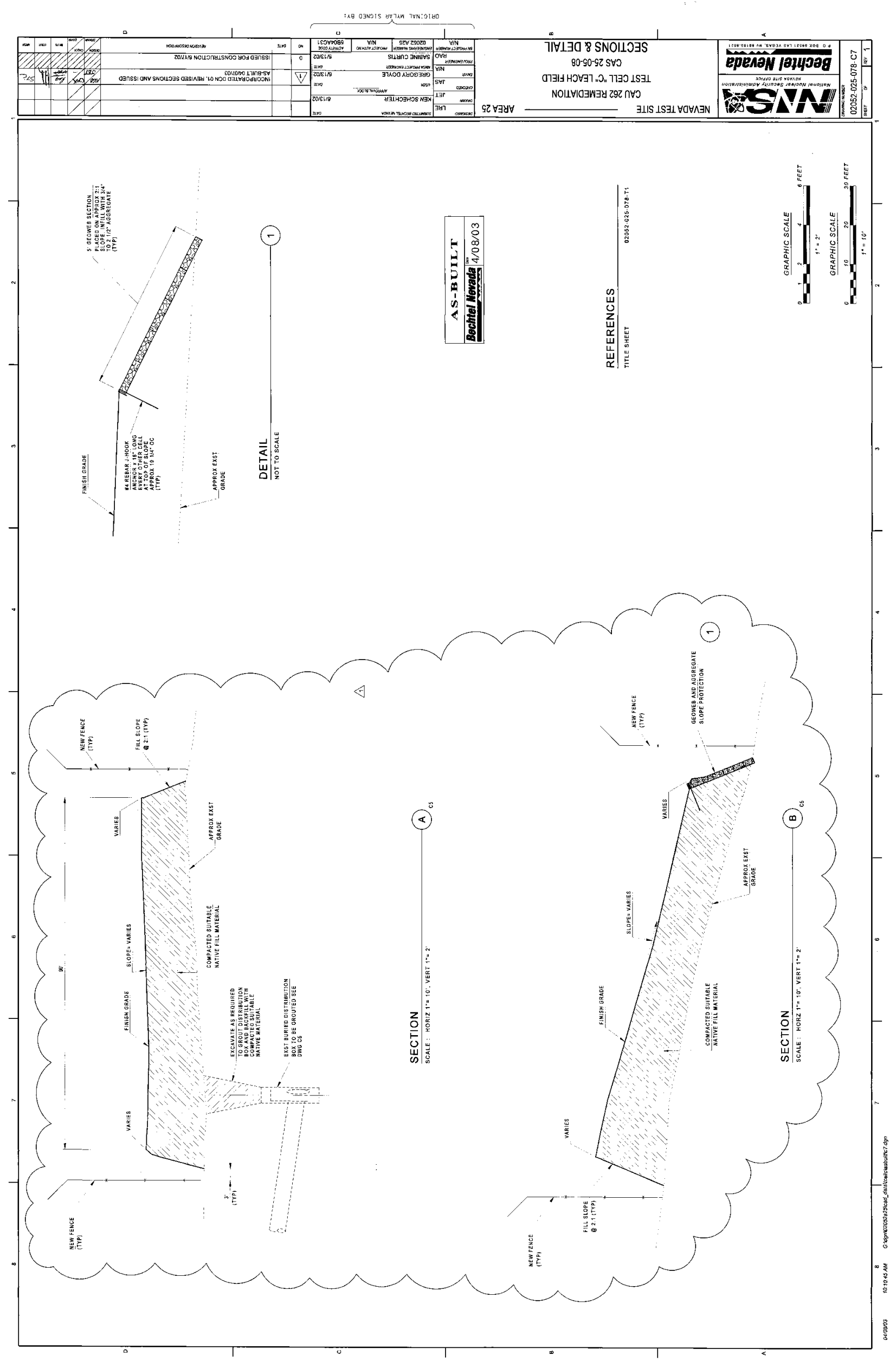




\section{APPENDIX G}

\section{USE RESTRICTION DOCUMENTATION}


CLOSURE RE PORT - CAU 262

Section: Appendix G

Revision : 1

Date: July 2003

THIS PAGE INTENTIONALLY LEFT BLANK 


\section{CAU Use Restriction Information}

CAU Number/Description: CAU 262: Area 25 Septic Systems and UDP, Nevada Test Site, Nevada

Applicable CAS Numbers/Descriptions: CAS 25-02-06, Underground Storage Tank

Contact (organization/project): NNSA/NSO Industrial Sites Project Manager

Surveyed Area (UTM coordinates, Zone 11, NAD 27):

CAS 25-02-06, Underground Storage Tank

NW tank corner: $\quad 4,073,319.88 \mathrm{~m} \mathrm{~N} \quad 562,076.91 \mathrm{~m} \mathrm{E}$

NE tank corner: $\quad 4,073,319.36 \mathrm{~m} \mathrm{~N} \quad 562,079.77 \mathrm{~m} \mathrm{E}$

SE tank corner: $\quad 4,073,304.24 \mathrm{~m} \mathrm{~N} \quad 562,076.32 \mathrm{~m} \mathrm{E}$

SW tank corner: $\quad 4,073,304.85 \mathrm{~m} \mathrm{~N} \quad 562,073.85 \mathrm{~m} \mathrm{E}$

Survey Date $\underline{\text { 02/13/2003 }}$ Survey Method Transit Datum NAD 1927 Zone UTM Zone 11

Site Monitoring Requirements: Visual Inspections

Monitoring Frequency (quarterly, annually?): Annually

If Monitoring Has Started, Indicate Last Completion Date: N/A

$-$

\section{Use Restrictions}

The future use of any land related to this Corrective Action Unit (CAU), as described by the above surveyed location, is restricted from any DOE or Air Force activity that may alter or modify the containment control as approved by the state and identified in the CAU Closure Report or other CAU documentation unless appropriate concurrence is obtained in advance.

Comments: See the CAU 262 Closure Report (DOE/NV--897) for additional information on the condition of the site and any monitoring and/or inspection requirements. The "Underground Storage Tank" is actually the septic tank for the septic system.

Submitted By: SIGNATURE APPROVED

Date: $5 / 6 / 03$

Attachments: Site Figure showing survey locations and coordinates (CAS250206 UR.cdr). 


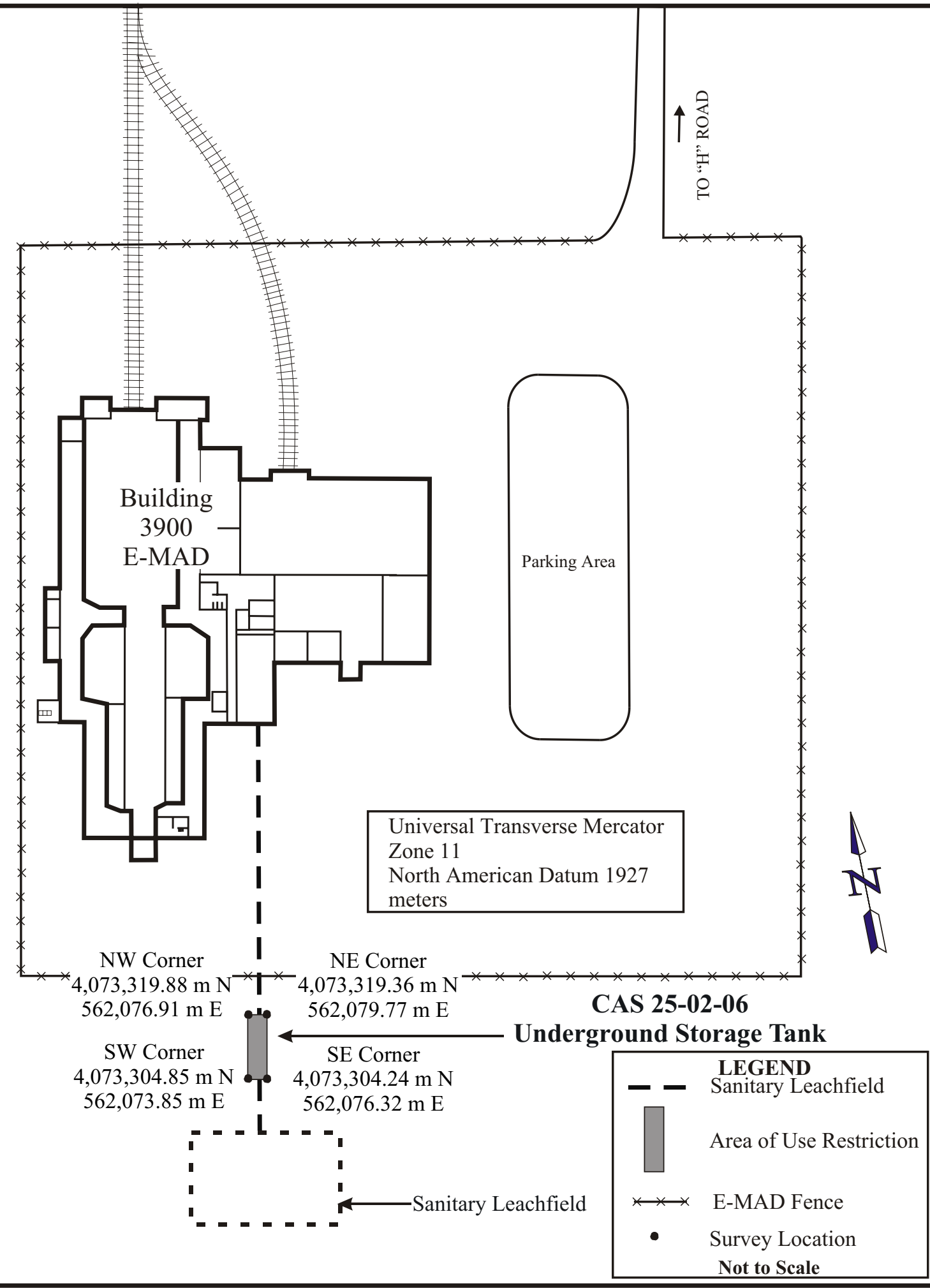

USE RESTRICTION BOUNDARIES FOR CAU 262, AREA 25 SEPTIC SYSTEMS AND UDP CAS 25-02-06, UNDERGROUND STORAGE TANK 


\section{CAU Use Restriction Information}

CAU Number/Description: CAU 262: Area 25 Septic Systems and UDP, Nevada Test Site, Nevada

Applicable CAS Numbers/Descriptions: CAS 25-05-03, Leachfield

Contact (organization/project): NNSA/NSO Industrial Sites Project Manager

Surveyed Area (UTM coordinates, Zone 11, NAD 27):

CAS 25-05-03, Leachfield

NW fence corner: $\quad 4,074,083.46 \mathrm{~m} \mathrm{~N} \quad 567,978.01 \mathrm{~m} \mathrm{E}$

NE fence corner: $\quad 4,074,093.86 \mathrm{~m} \mathrm{~N} \quad 568,053.31 \mathrm{~m} \mathrm{E}$

SE fence corner: $\quad 4,074,020.84 \mathrm{~m} \mathrm{~N} \quad 568,063.26 \mathrm{~m} \mathrm{E}$

SW fence corner: $\quad 4,074,010.41 \mathrm{~m} \mathrm{~N} \quad 567,987.90 \mathrm{~m} \mathrm{E}$

Survey Date $\underline{\text { 02/19/2003 }}$ Survey Method Transit Datum NAD 1927 Zone UTM Zone 11

Site Monitoring Requirements: Visual Inspections

Monitoring Frequency (quarterly, annually?): Annually

If Monitoring Has Started, Indicate Last Completion Date: N/A

\section{Use Restrictions}

The future use of any land related to this Corrective Action Unit (CAU), as described by the above surveyed location, is restricted from any DOE or Air Force activity that may alter or modify the containment control as approved by the state and identified in the CAU Closure Report or other CAU documentation unless appropriate concurrence is obtained in advance.

Comments: See the CAU 262 Closure Report (DOE/NV--897) for additional information on the condition of the site and any monitoring and/or inspection requirements.

Submitted By: SIGNATURE APPROVED Date: $5 / 6 / 03$

Attachments: Site Figure showing survey locations and coordinates (CAS250503 UR.cdr). 


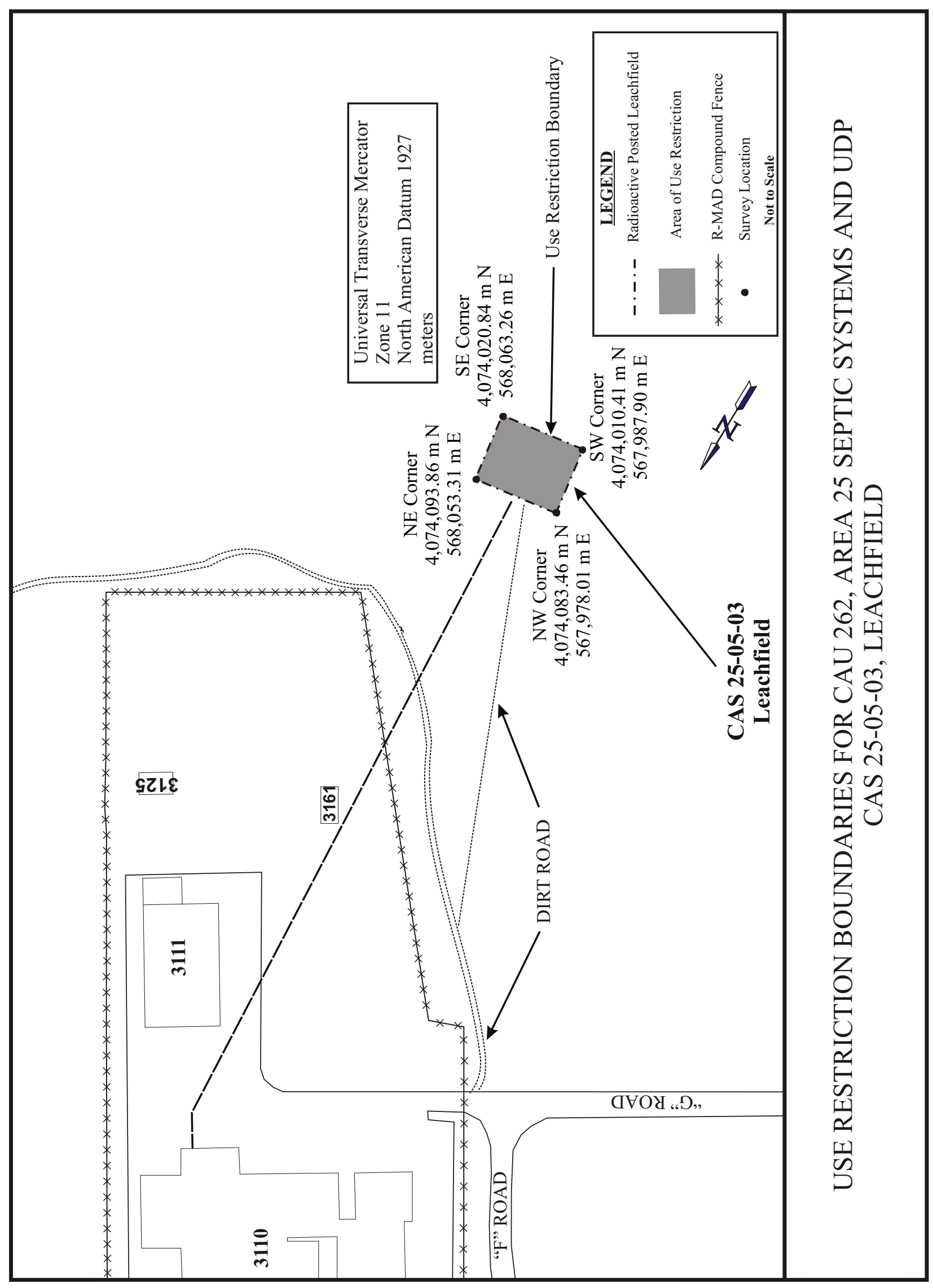




\section{CAU Use Restriction Information}

CAU Number/Description: CAU 262: Area 25 Septic Systems and UDP, Nevada Test Site, Nevada

Applicable CAS Numbers/Descriptions: CAS 25-05-06, Leachfield

Contact (organization/project): NNSA/NSO Industrial Sites Project Manager

Surveyed Area (UTM coordinates, Zone 11, NAD 27):

CAS 25-05-06, Leachfield

NW fence corner: $\quad 4,073,210.00 \mathrm{~m} \mathrm{~N} \quad 561,978.86 \mathrm{~m} \mathrm{E}$

NE fence corner: $\quad 4,073,200.11 \mathrm{~m} \mathrm{~N} \quad 562,040.77 \mathrm{~m} \mathrm{E}$

SE fence corner: $\quad 4,073,126.43 \mathrm{~m} \mathrm{~N} \quad 562,028.05 \mathrm{~m} \mathrm{E}$

SW fence corner: $\quad 4,073,136.21 \mathrm{~m} \mathrm{~N} \quad 561,965.51 \mathrm{~m} \mathrm{E}$

Survey Date $\underline{\text { 02/13/2003 }}$ Survey Method Transit Datum NAD 1927 Zone UTM Zone 11

Site Monitoring Requirements: Visual Inspections

Monitoring Frequency (quarterly, annually?): Annually

If Monitoring Has Started, Indicate Last Completion Date: N/A

\section{Use Restrictions}

The future use of any land related to this Corrective Action Unit (CAU), as described by the above surveyed location, is restricted from any DOE or Air Force activity that may alter or modify the containment control as approved by the state and identified in the CAU Closure Report or other CAU documentation unless appropriate concurrence is obtained in advance.

Comments: See the CAU 262 Closure Report (DOE/NV--897) for additional information on the condition of the site and any monitoring and/or inspection requirements.

Submitted By: SIGNATURE APPROVED Date: $\underline{5 / 6 / 03}$

Attachments: Site Figure showing survey locations and coordinates (CAS250506 UR.cdr). 


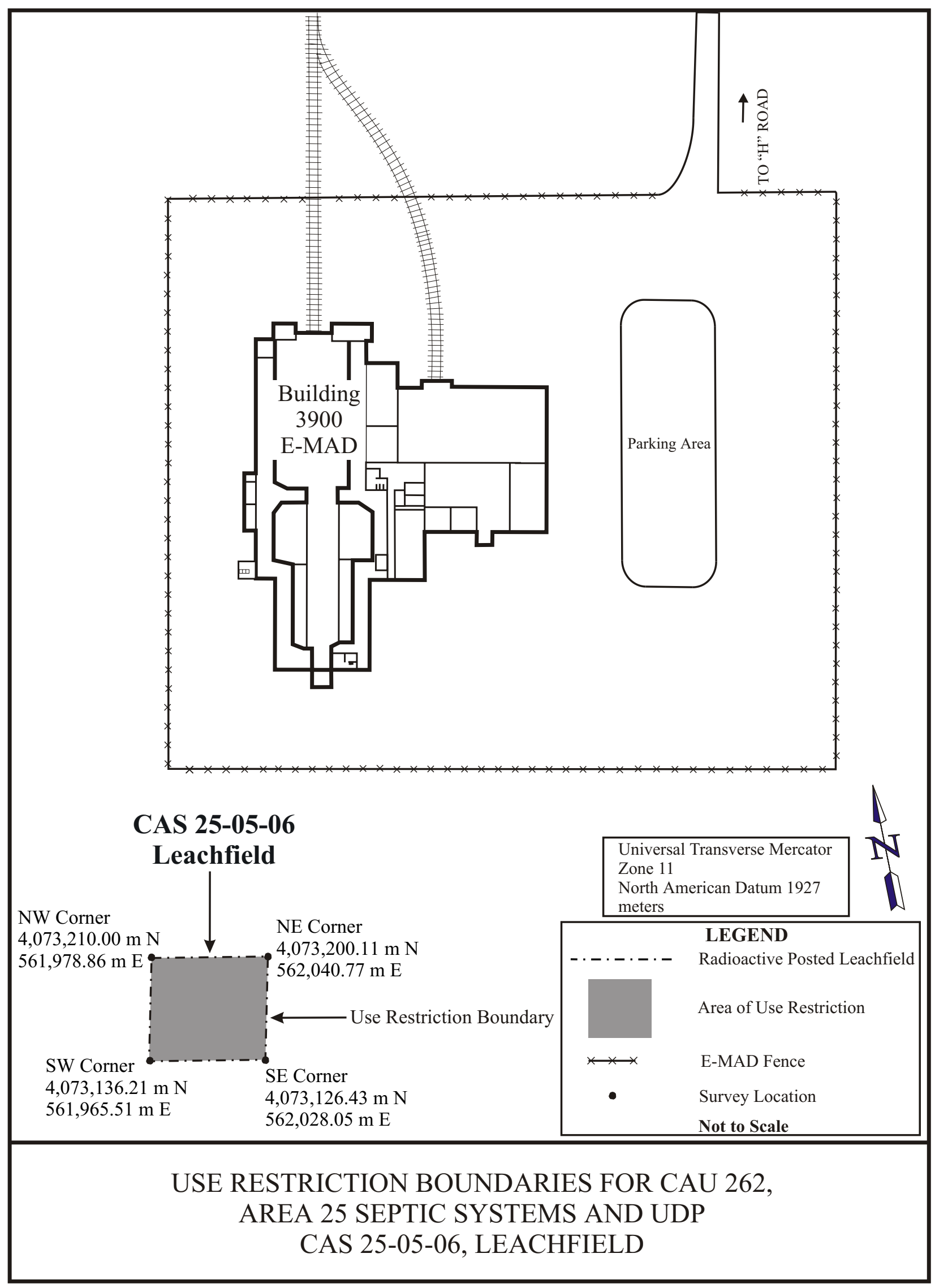




\section{CAU Use Restriction Information}

CAU Number/Description: CAU 262: Area 25 Septic Systems and UDP, Nevada Test Site, Nevada

Applicable CAS Numbers/Descriptions: CAS 25-05-08, Radioactive Leachfield

Contact (organization/project): NNSA/NSO Industrial Sites Project Manager

Surveyed Area (UTM coordinates, Zone 11, NAD 27):

CAS 25-05-08, Radioactive Leachfield

Fence angle 1: 4,076,095.23 m N $564,599.61 \mathrm{~m} \mathrm{E}$

Fence angle 2: 4,076,110.82 $\mathrm{m} \mathrm{N} \quad 564,599.50 \mathrm{~m} \mathrm{E}$

Fence angle 3: 4,076,127.80 $\mathrm{m} \mathrm{N} \quad 564,612.21 \mathrm{~m} \mathrm{E}$

Fence angle 4: 4,076,128.42 $\mathrm{m} \mathrm{N} \quad 564,618.30 \mathrm{~m} \mathrm{E}$

Fence angle 5: 4,076,108.96 $\mathrm{m} \mathrm{N} \quad 564,640.24 \mathrm{~m} \mathrm{E}$

Fence angle 6: 4,076,081.06 $\mathrm{m} \mathrm{N} \quad 564,616.33 \mathrm{~m} \mathrm{E}$

Survey Date $\underline{\text { 03/19/2003 }}$ Survey Method Transit Datum NAD 1927 Zone UTM Zone 11

Site Monitoring Requirements: Visual Inspections

Monitoring Frequency (quarterly, annually?): Annually

If Monitoring Has Started, Indicate Last Completion Date: N/A

\section{Use Restrictions}

The future use of any land related to this Corrective Action Unit (CAU), as described by the above surveyed location, is restricted from any DOE or Air Force activity that may alter or modify the containment control as approved by the state and identified in the CAU Closure Report or other CAU documentation unless appropriate concurrence is obtained in advance.

Comments: The Radioactive Leachfield Use Restriction is delineated by an irregularly-shaped fence. Survey points were measured at those locations where an angle in the fence occurred. See the CAU 262 Closure Report (DOE/NV--897) for additional information on the condition of the site and any monitoring and/or inspection requirements.

Submitted By: SIGNATURE APPROVED Date: $5 / 6 / 03$

Attachments: Site Figure showing survey locations and coordinates (CAS250508 UR.cdr). 


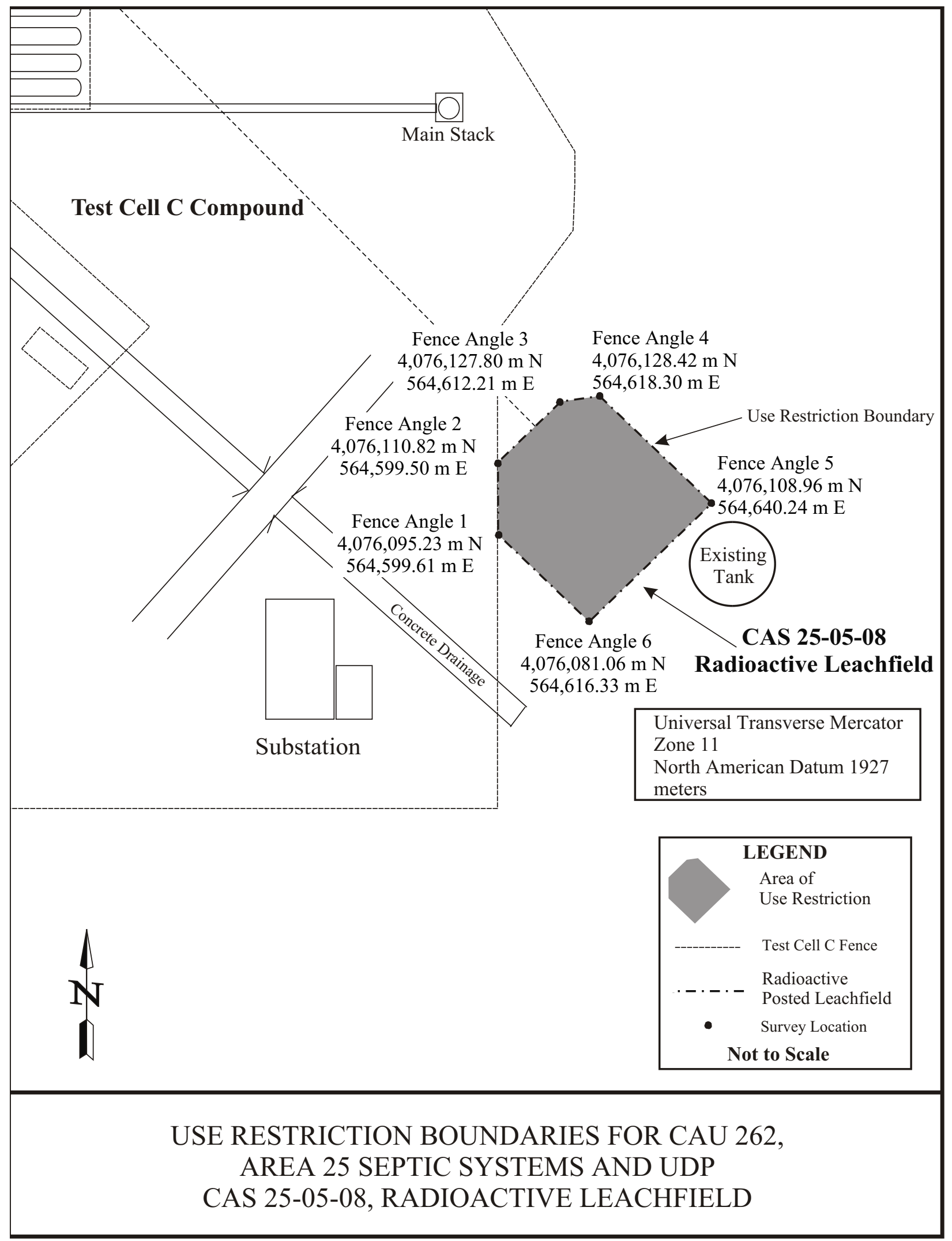




\section{APPENDIX H}

\section{SITE CLOSURE PHOTOGRAPHS}


CLOSURE RE PORT - CAU 262

Section: Appendix H

Revision : 1

Date: July 2003

THIS PAGE INTENTIONALLY LEFT BLANK 


\section{PHOTOGRAPH LOG}

\begin{tabular}{|c|c|c|}
\hline $\begin{array}{c}\text { PHOTOGRAPH } \\
\text { NUMBER }\end{array}$ & DATE & DESCRIPTION \\
\hline \multicolumn{3}{|r|}{ CAS 25-05-05 } \\
\hline 1 & $12 / 04 / 2002$ & Pumping septic tank \\
\hline 2 & $12 / 04 / 2002$ & Adding soil to solidification basin \\
\hline 3 & $01 / 08 / 2003$ & Septic tank top opened \\
\hline 4 & $01 / 08 / 2003$ & Mixing septic tank contents \\
\hline 5 & $01 / 22 / 2003$ & Removing septic tank contents \\
\hline 6 & $01 / 30 / 2003$ & Rinsing septic tank \\
\hline 7 & $03 / 05 / 2003$ & Septic tank filled with concrete \\
\hline 8 & 03/06/2003 & Excavation backfilled \\
\hline \multicolumn{3}{|r|}{ CAS 25-05-12 } \\
\hline 9 & $12 / 09 / 2002$ & Pumping septic tank \\
\hline 10 & $01 / 09 / 2003$ & Septic Tank Exposed \\
\hline 11 & $01 / 16 / 2003$ & Septic tank top opened \\
\hline 12 & $01 / 30 / 2003$ & Septic tank excavation \\
\hline 13 & $02 / 04 / 2003$ & Removing septic tank contents \\
\hline 14 & $03 / 05 / 2003$ & Septic tank filled with concrete \\
\hline 15 & $03 / 10 / 2003$ & Excavation backfilled \\
\hline \multicolumn{3}{|r|}{ CAS 25-04-07 } \\
\hline 16 & $12 / 17 / 2002$ & Filling septic tank with grout \\
\hline 17 & $12 / 17 / 2002$ & Septic tank filled with grout \\
\hline 18 & $12 / 19 / 2002$ & Septic tank area backfilled \\
\hline \multicolumn{3}{|r|}{ CAS 25-04-06 System A } \\
\hline 19 & $12 / 17 / 2002$ & Septic tank and excavation filled with grout \\
\hline 20 & $12 / 19 / 2002$ & Septic tank area backfilled \\
\hline \multicolumn{3}{|r|}{ CAS 25-04-06 System B } \\
\hline 21 & $12 / 17 / 2002$ & Septic tank filled with grout \\
\hline
\end{tabular}




\section{PHOTOGRAPH LOG (Continued)}

\begin{tabular}{|c|c|c|}
\hline $\begin{array}{c}\text { PHOTOGRAPH } \\
\text { NUMBER }\end{array}$ & DATE & DESCRIPTION \\
\hline \multicolumn{3}{|r|}{ CAS 25-02-06 } \\
\hline 22 & $01 / 27 / 2003$ & Septic tank exposed \\
\hline 23 & $01 / 30 / 2003$ & Filling septic tank with bulk cement \\
\hline 24 & $02 / 10 / 2003$ & Septic tank filled with grout \\
\hline 25 & 03/06/2003 & Use Restriction signs \\
\hline \multicolumn{3}{|r|}{ CAS 25-05-03 } \\
\hline 26 & $01 / 28 / 2003$ & Distribution box filled with grout \\
\hline 27 & $01 / 28 / 2003$ & Installing soil cover \\
\hline 28 & $02 / 19 / 2003$ & Soil cover completed \\
\hline 29 & $02 / 20 / 2003$ & Installing erosion protection \\
\hline 30 & $02 / 24 / 2003$ & Installing rip rap \\
\hline 31 & $03 / 05 / 2003$ & Use Restriction signs \\
\hline \multicolumn{3}{|r|}{ CAS 25-05-06 } \\
\hline 32 & 03/05/2003 & Use Restriction signs and chain link security fence \\
\hline \multicolumn{3}{|r|}{ CAS 25-05-08 } \\
\hline 33 & $02 / 04 / 2003$ & Filling monitoring tubes with grout \\
\hline 34 & $02 / 18 / 2003$ & Leachfield before closure activities \\
\hline 35 & $02 / 28 / 2003$ & Distribution box filled with grout \\
\hline 36 & $02 / 28 / 2003$ & Installing soil cover \\
\hline 37 & 03/17/2003 & Installing erosion protection \\
\hline 38 & $04 / 10 / 2003$ & Use Restriction signs and chain link security fence \\
\hline \multicolumn{3}{|r|}{ CAS 25-51-01 } \\
\hline 39 & $06 / 19 / 2003$ & CAS location looking north \\
\hline 40 & $06 / 19 / 2003$ & CAS location looking south \\
\hline
\end{tabular}




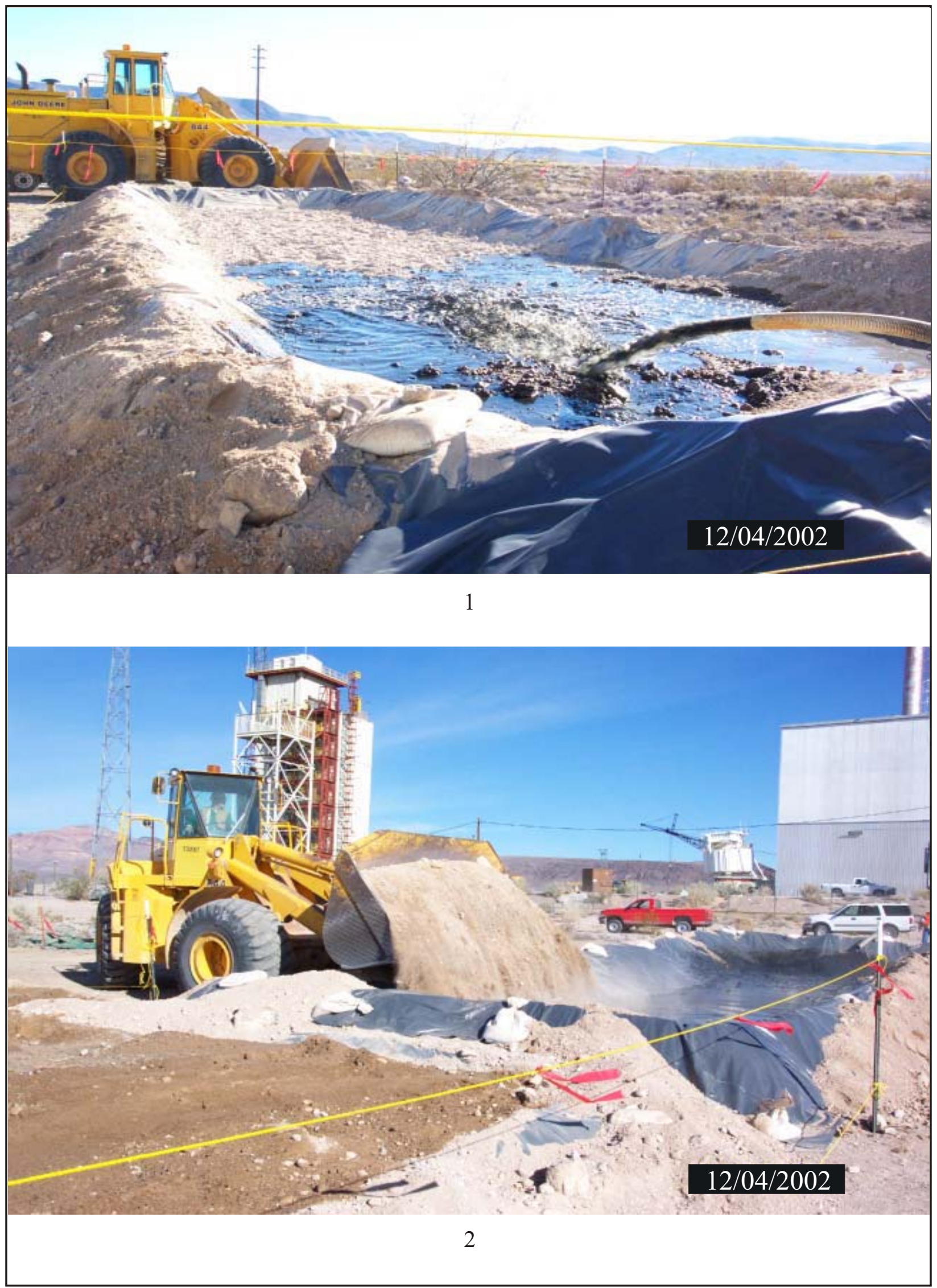


CLOSURE REPORT - CAU 262

Section: Appendix H

Revision: 1

Date: July 2003

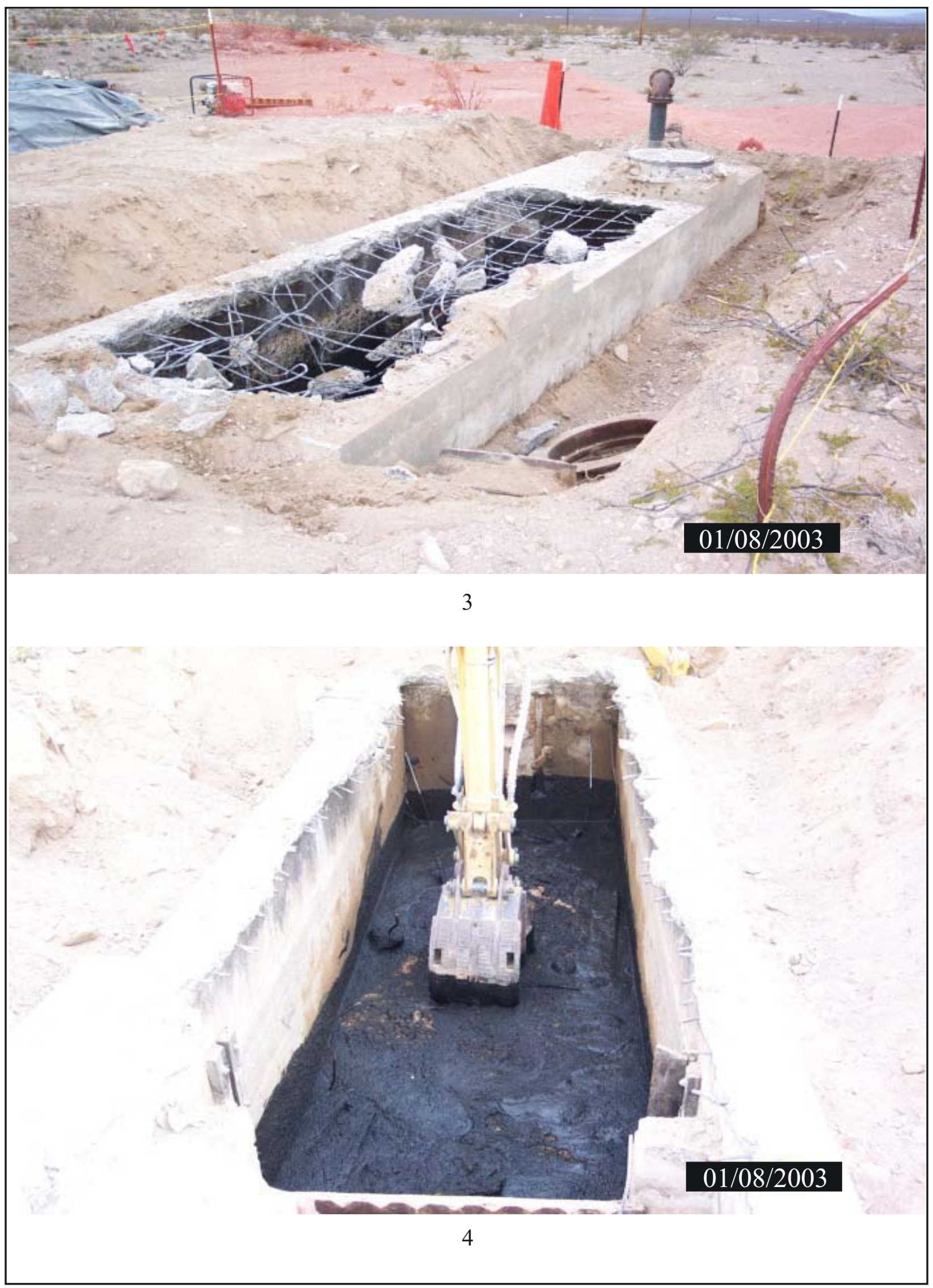


CLOSURE REPORT - CAU 262

Section: Appendix H

Revision: 1

Date: July 2003

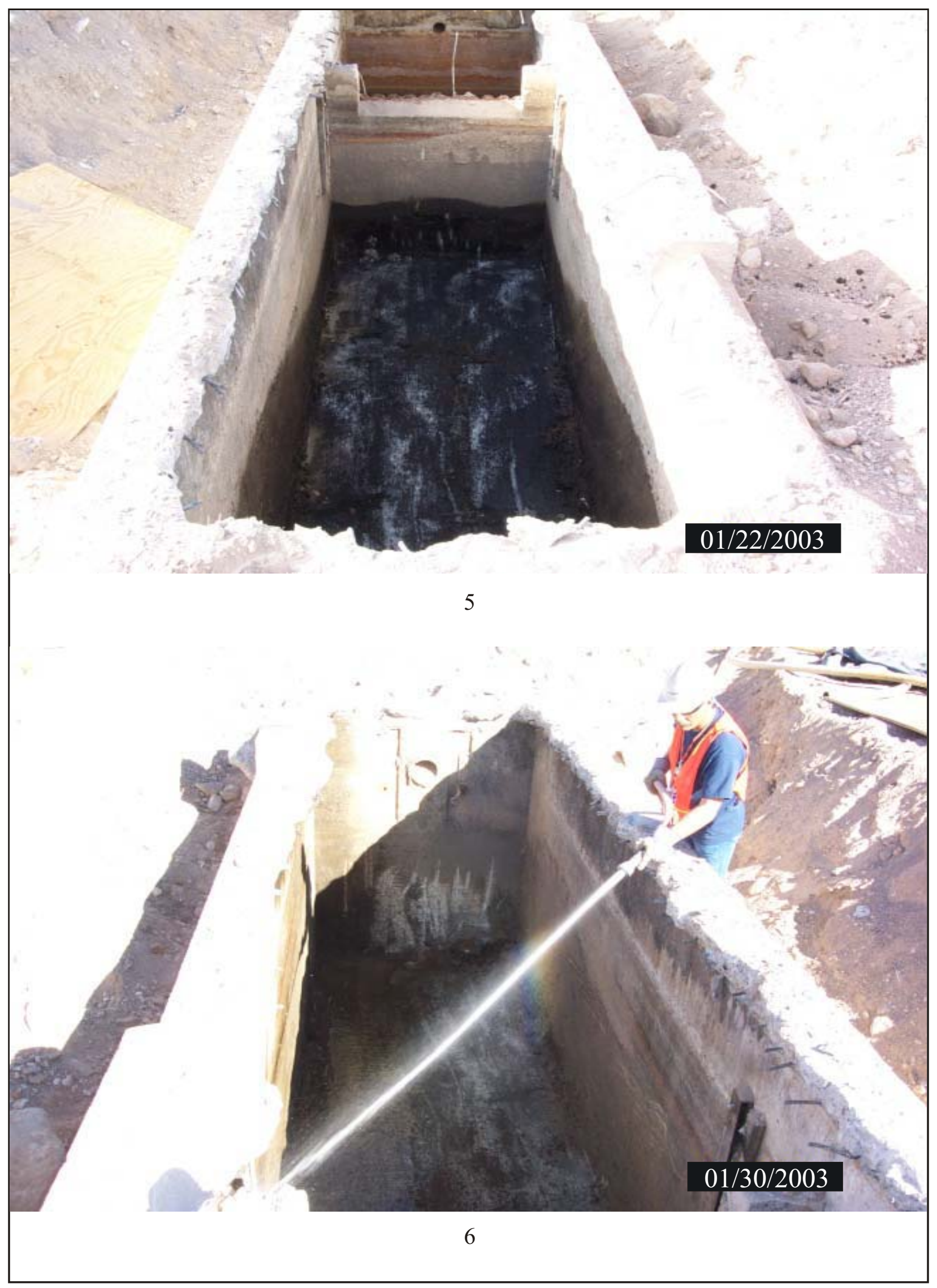


CLOSURE REPORT - CAU 262

Section: Appendix H

Revision: 1

Date: July 2003

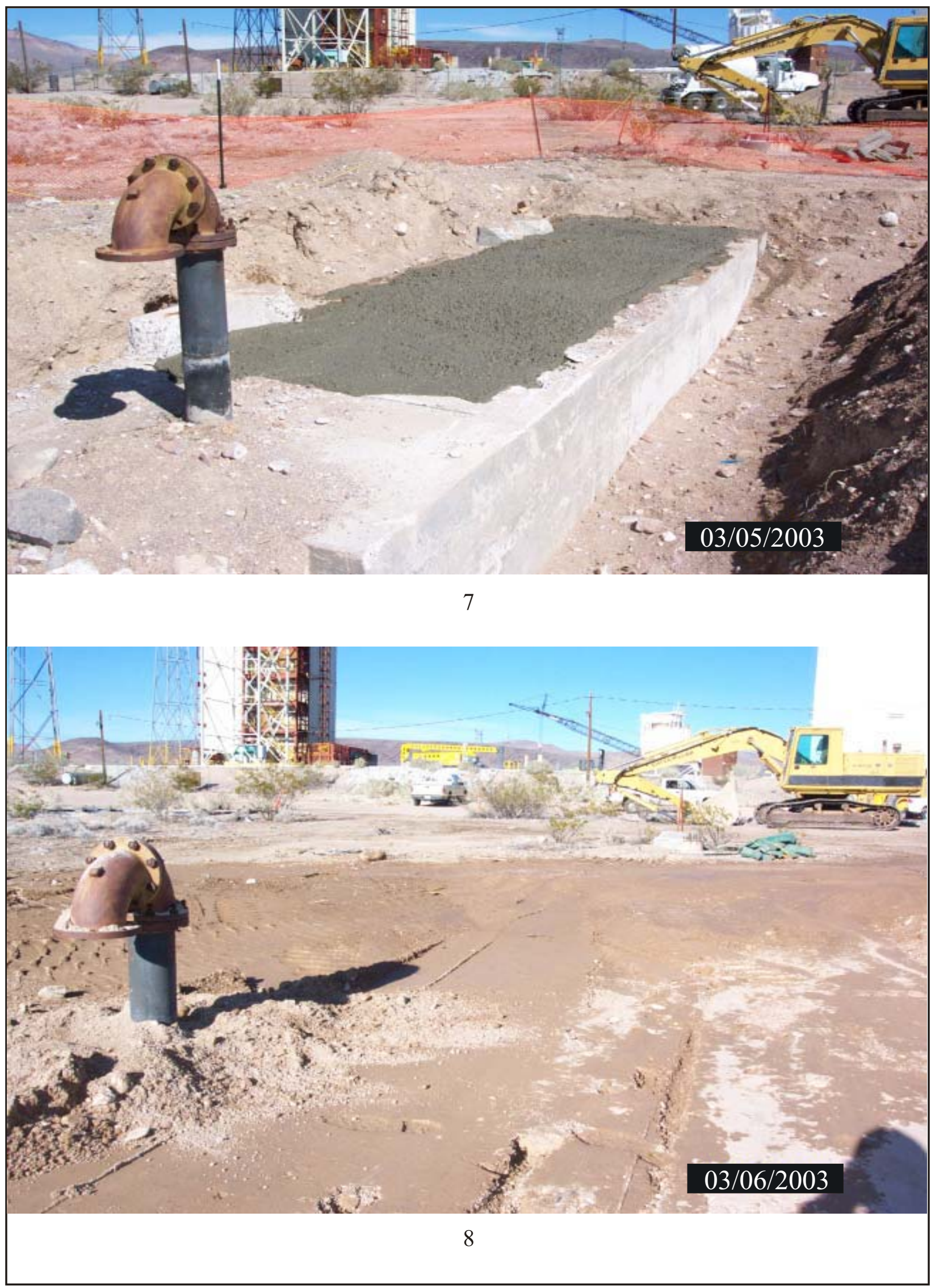


CLOSURE REPORT - CAU 262

Section: Appendix H

Revision: 1

Date: July 2003

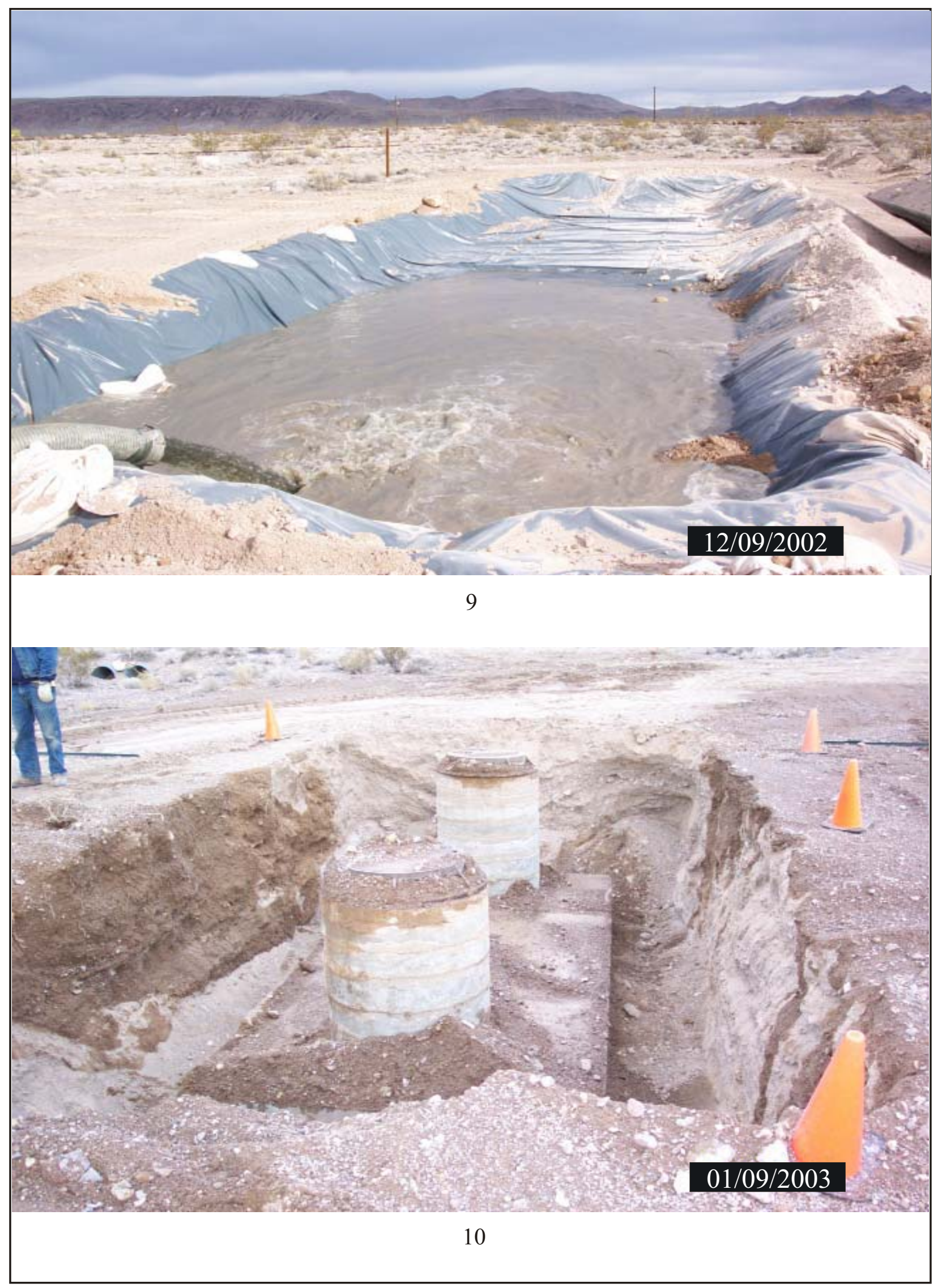




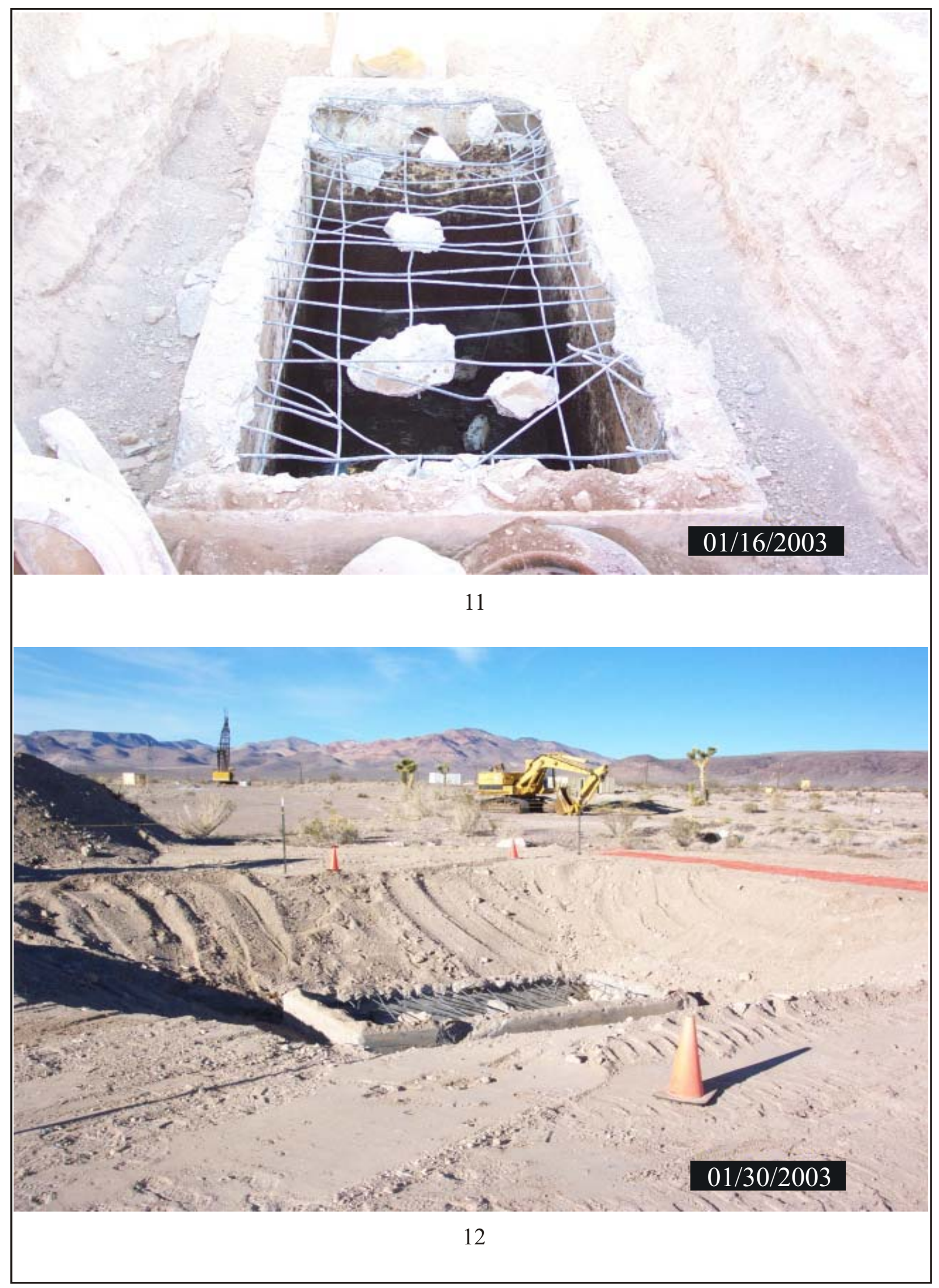




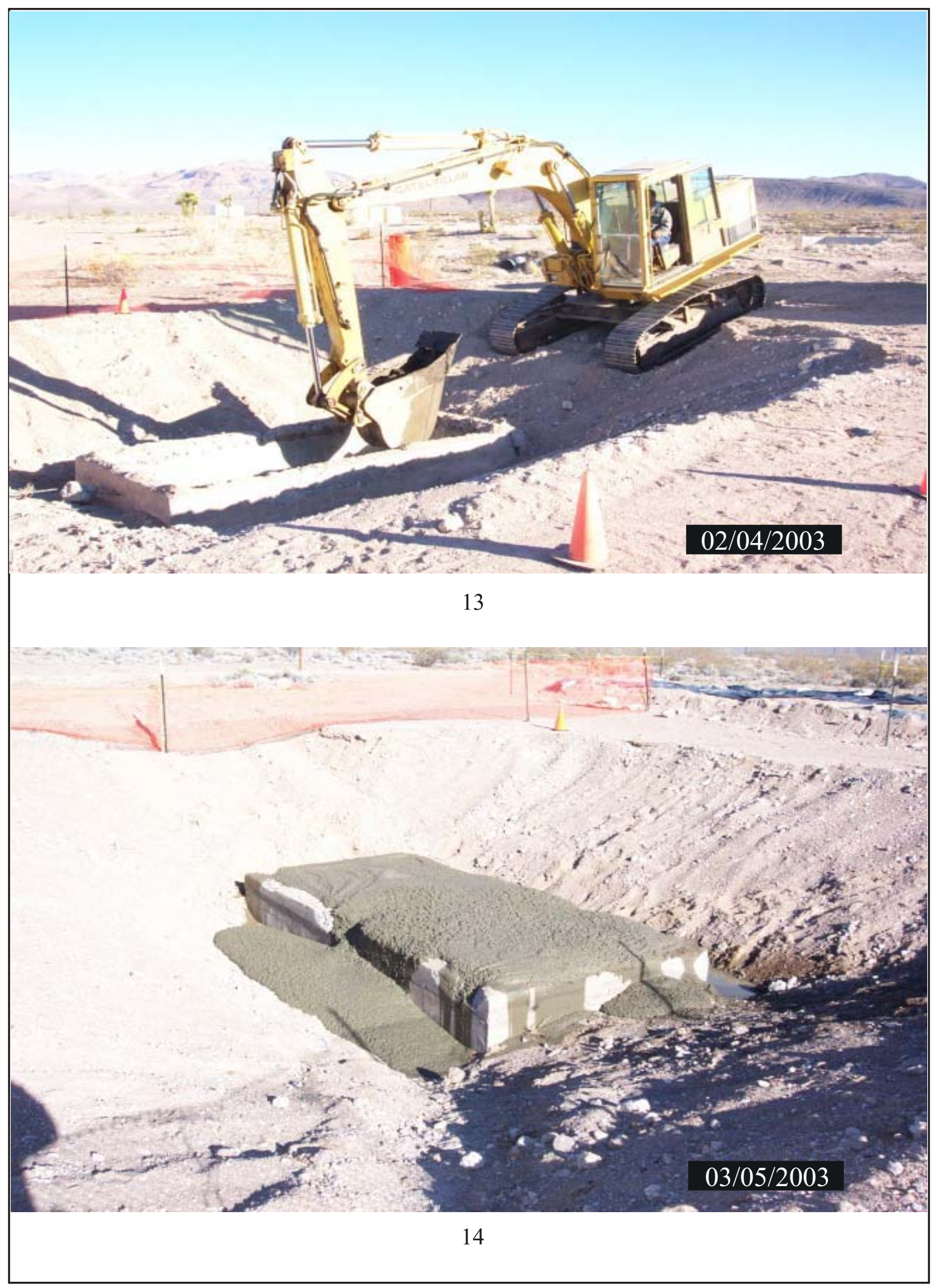


CLOSURE REPORT - CAU 262

Section: Appendix H

Revision: 1

Date: July 2003

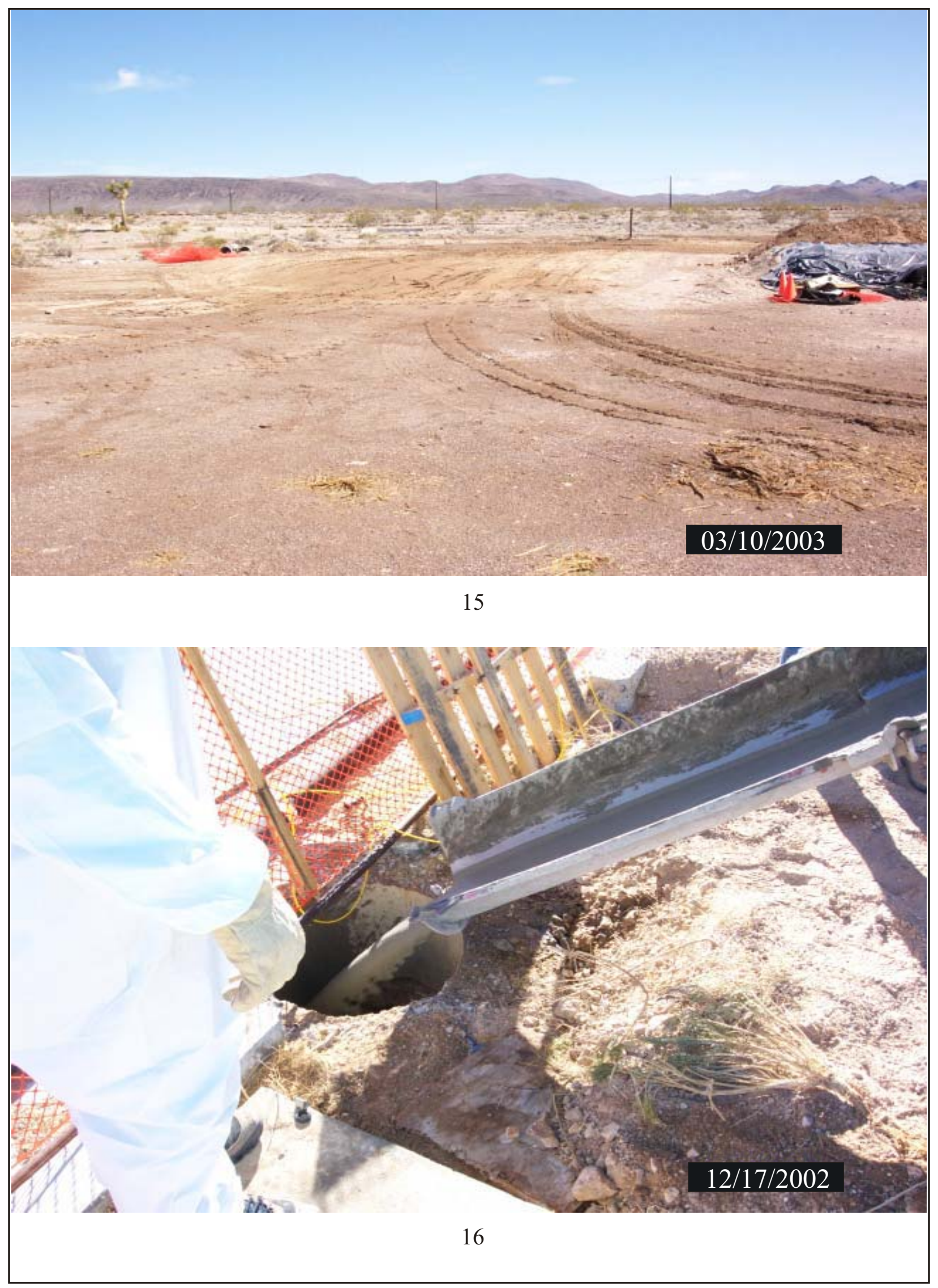


CLOSURE REPORT - CAU 262

Section: Appendix H

Revision: 1

Date: July 2003

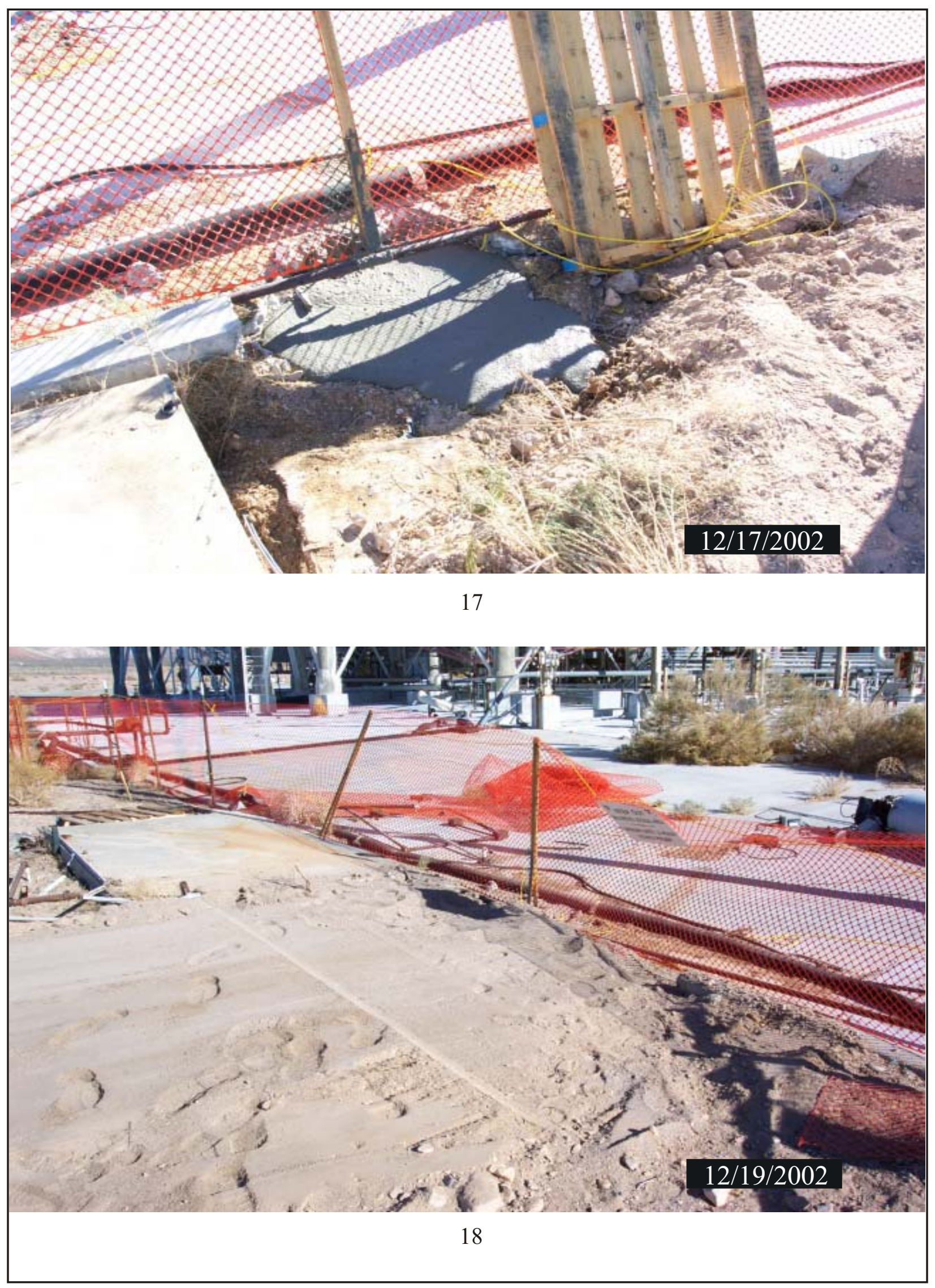


CLOSURE REPORT - CAU 262

Section: Appendix H

Revision: 1

Date: July 2003
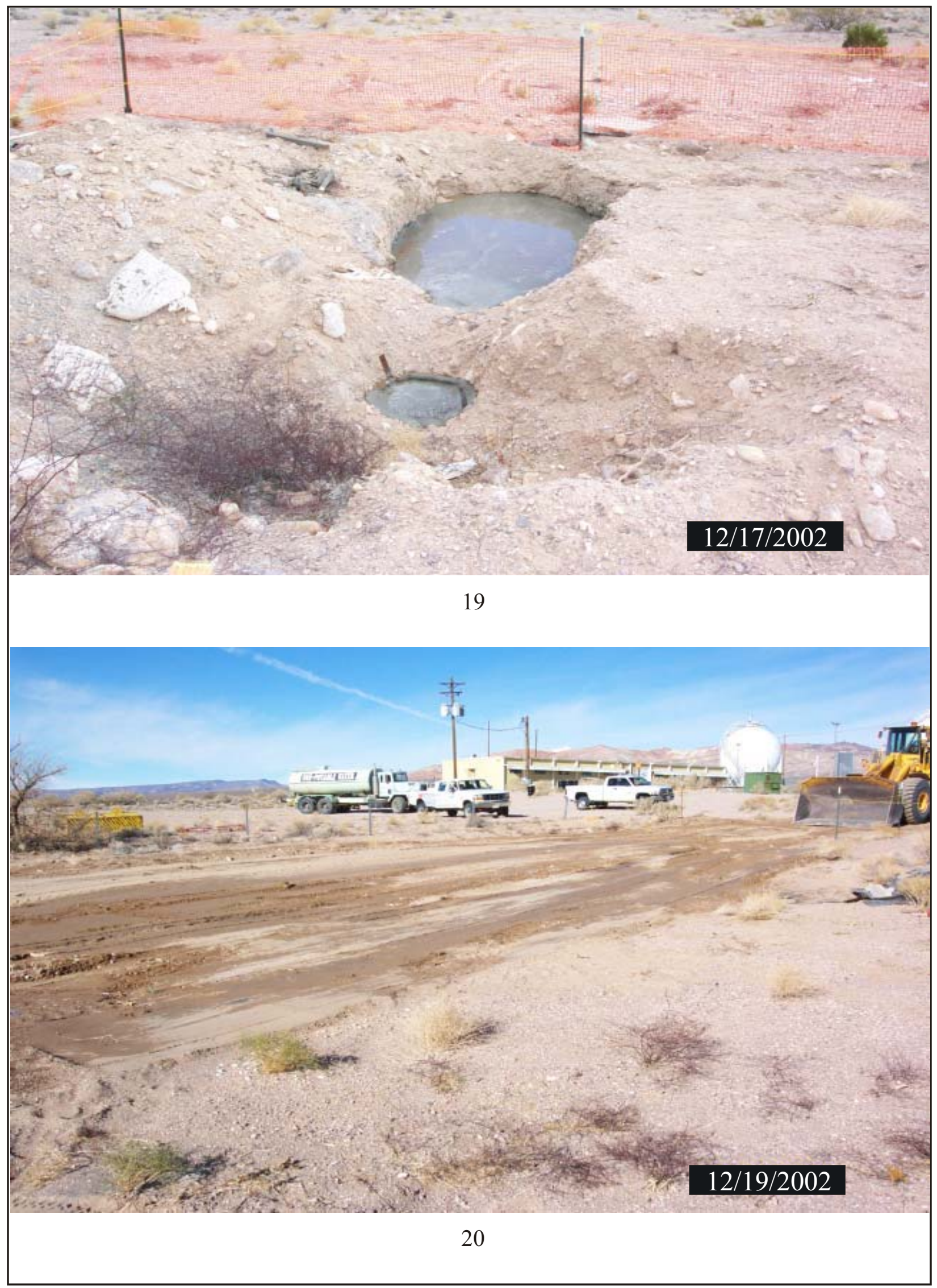
CLOSURE REPORT - CAU 262

Section: Appendix H

Revision: 1

Date: July 2003

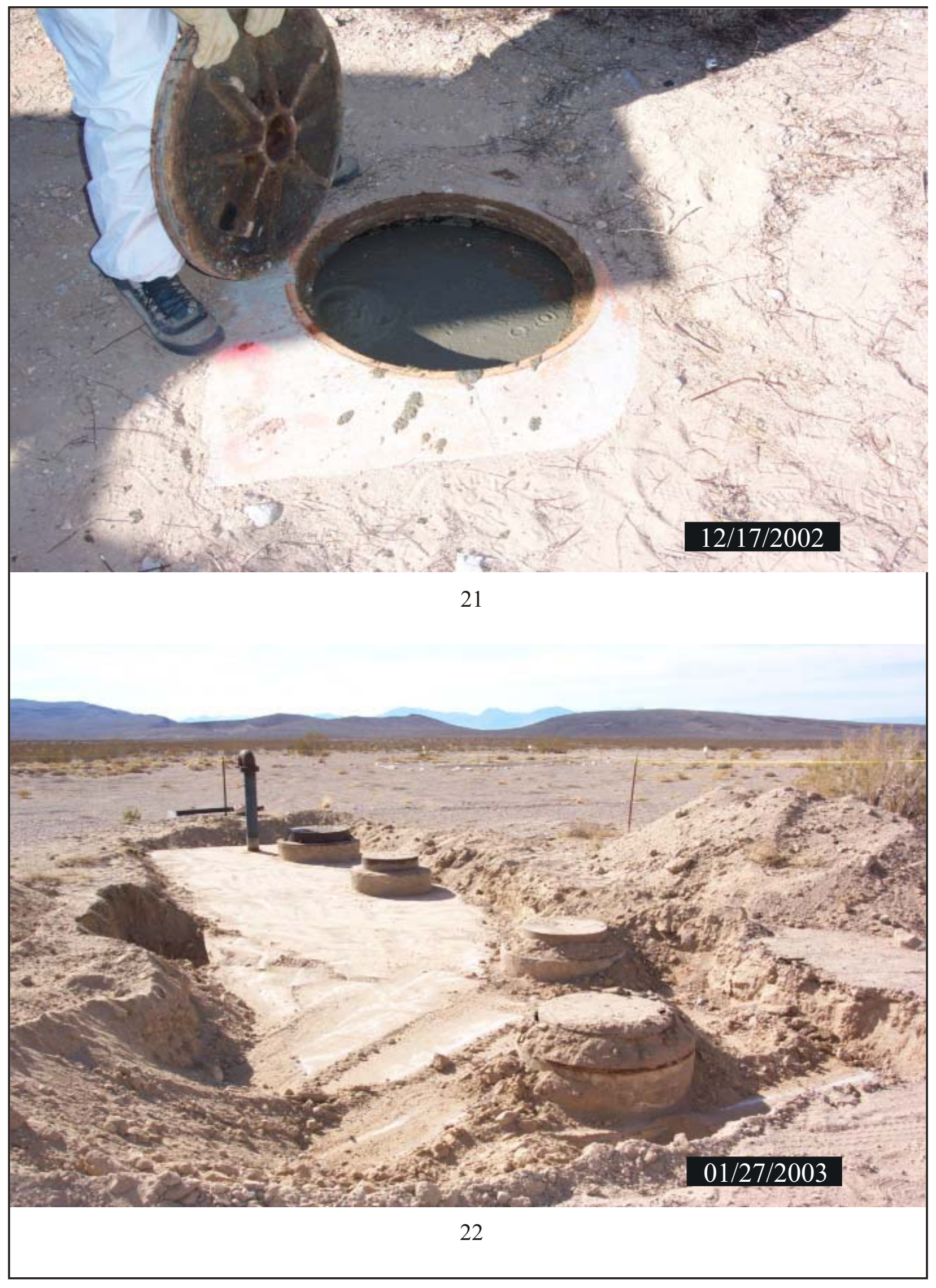


CLOSURE REPORT - CAU 262

Section: Appendix H

Revision: 1

Date: July 2003

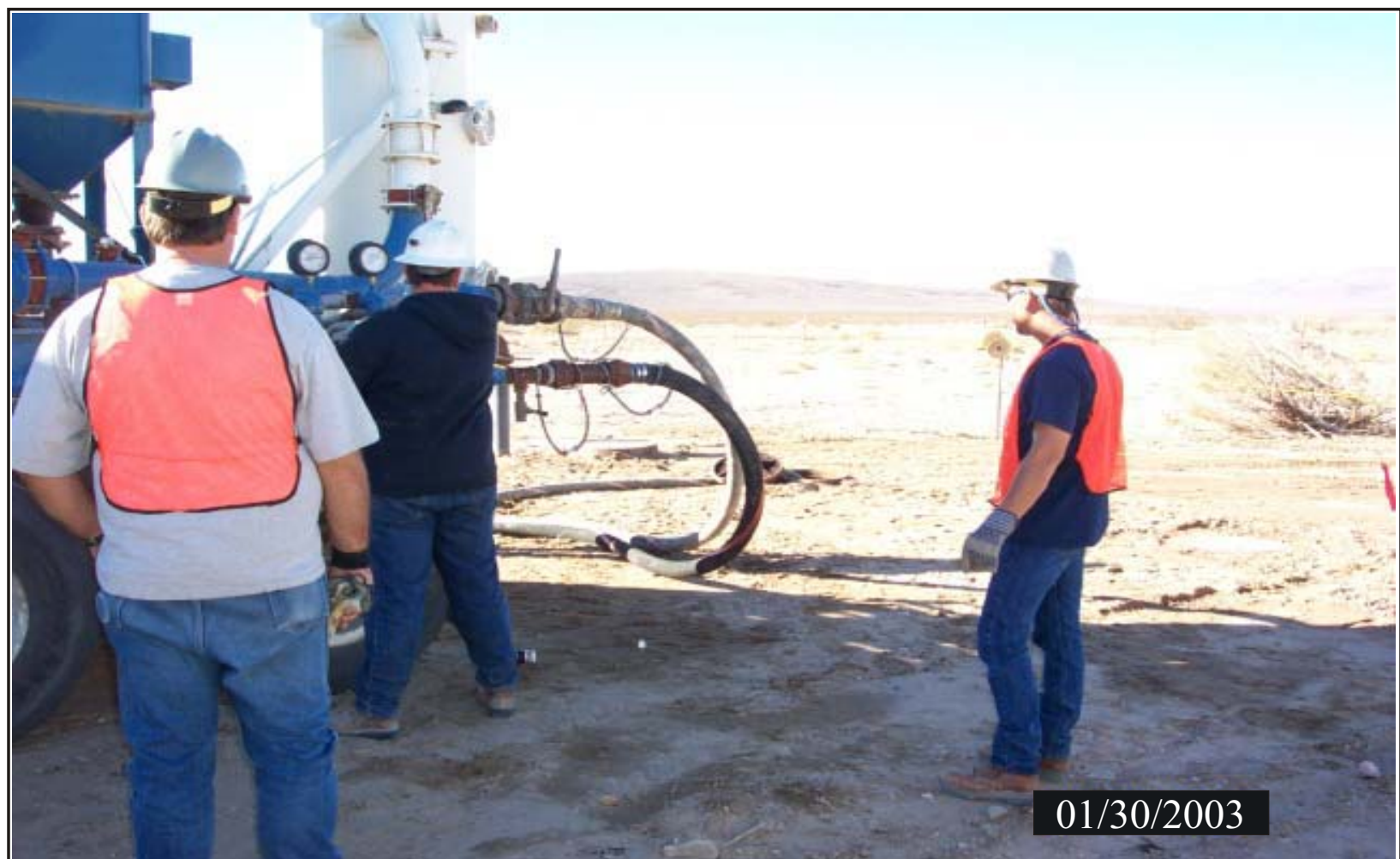

23

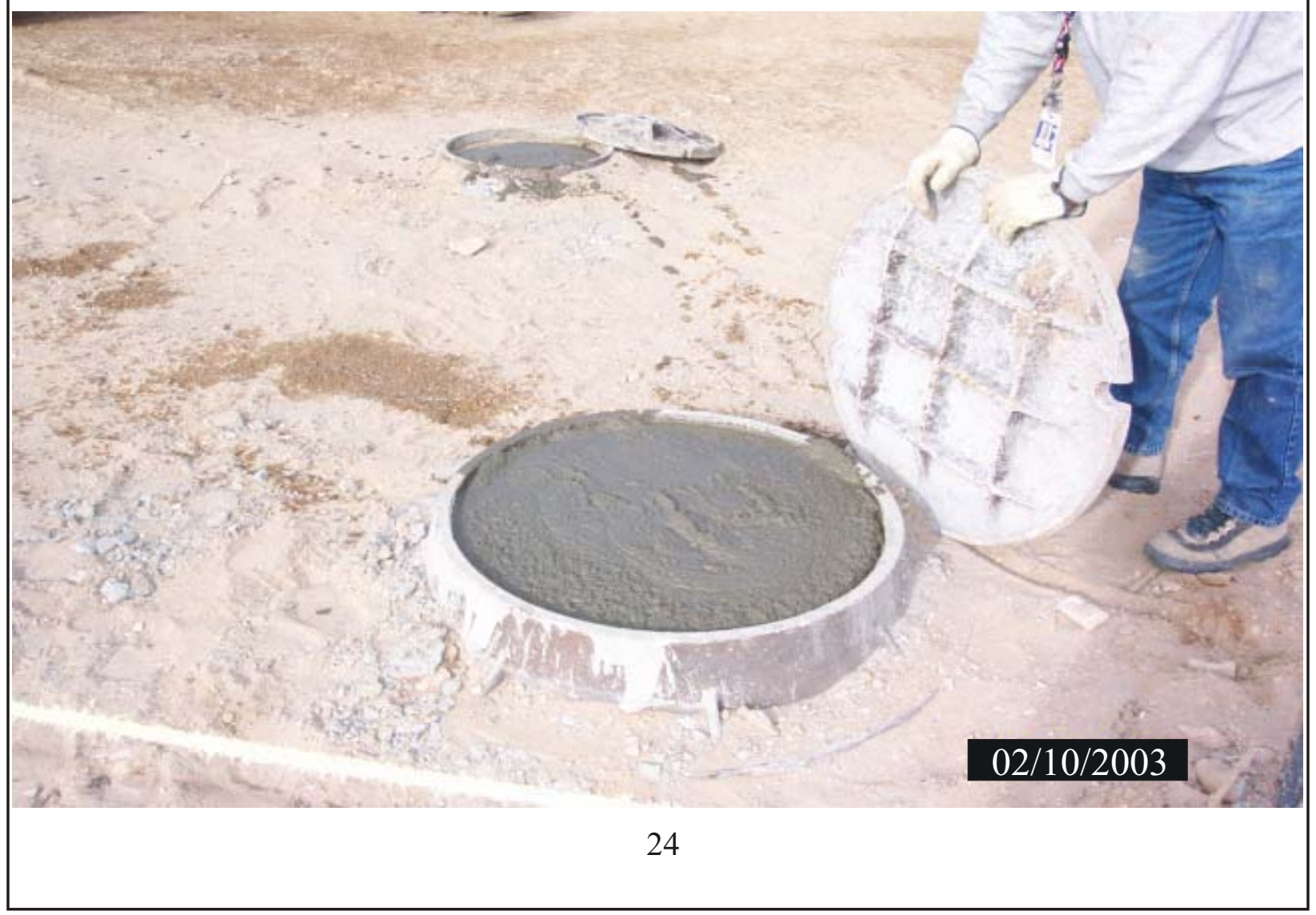

$\mathrm{H}-14$ 


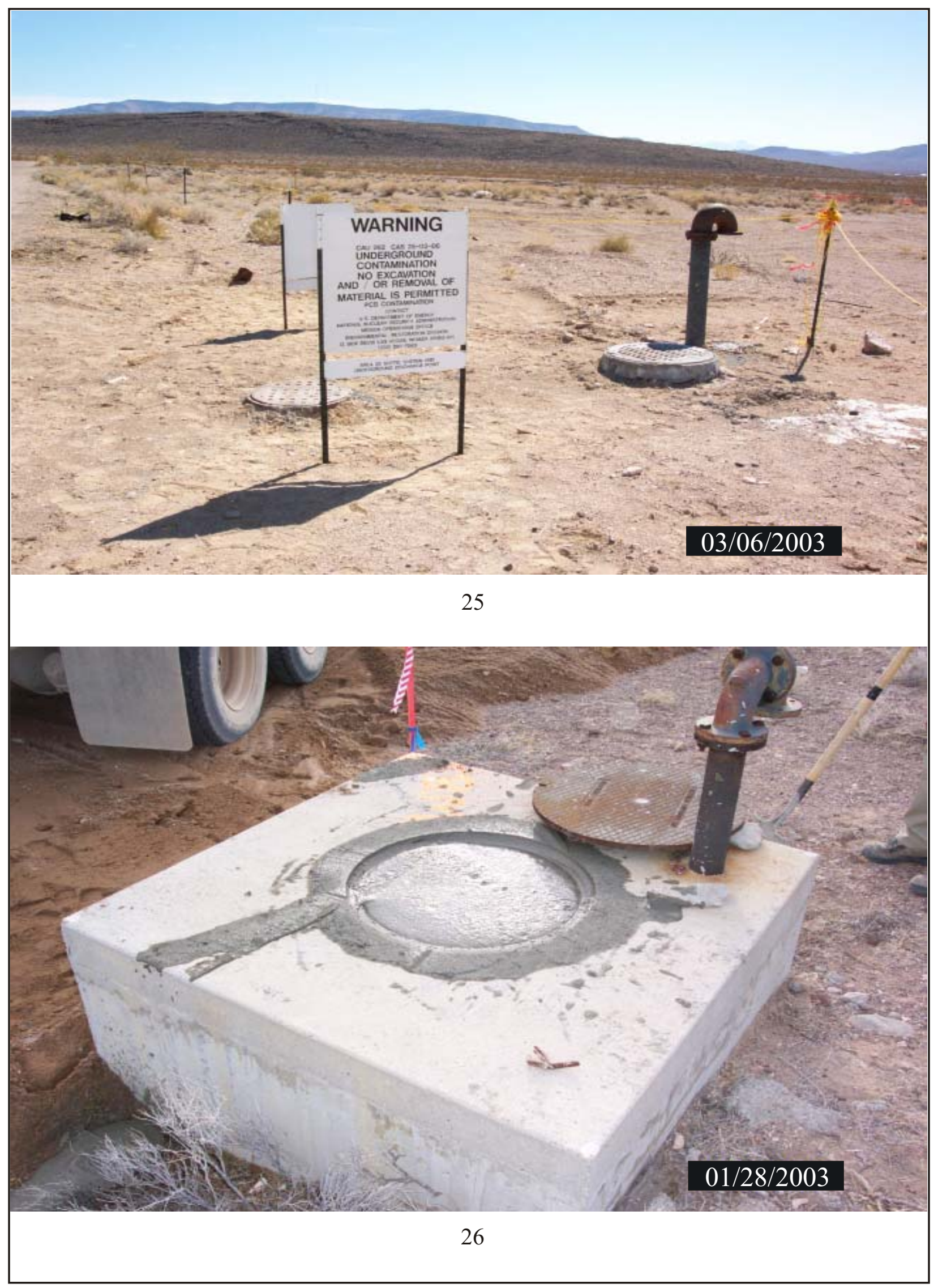


CLOSURE REPORT - CAU 262

Section: Appendix H

Revision: 1

Date: July 2003

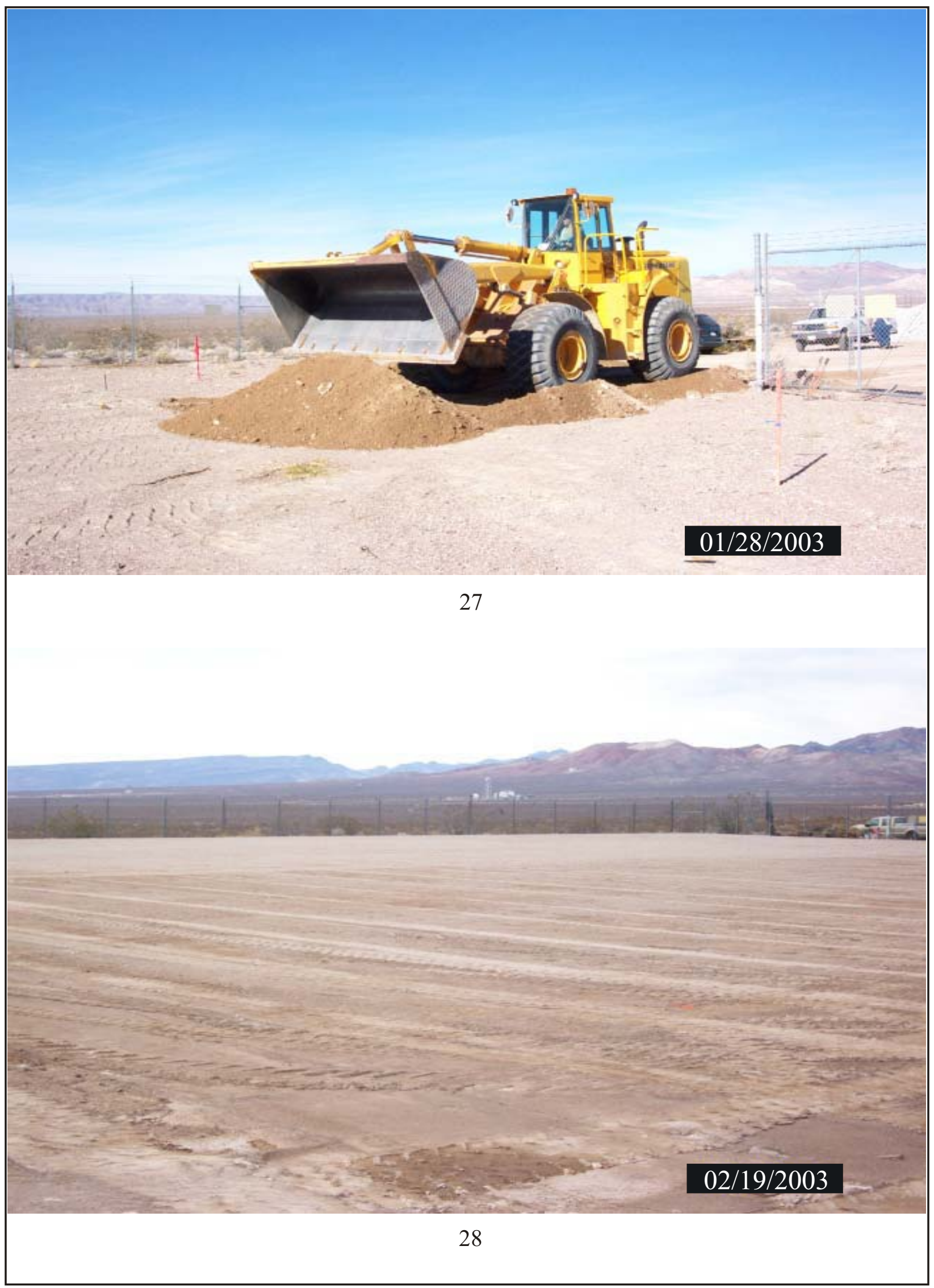

H-16 
CLOSURE REPORT - CAU 262

Section: Appendix H

Revision: 1

Date: July 2003

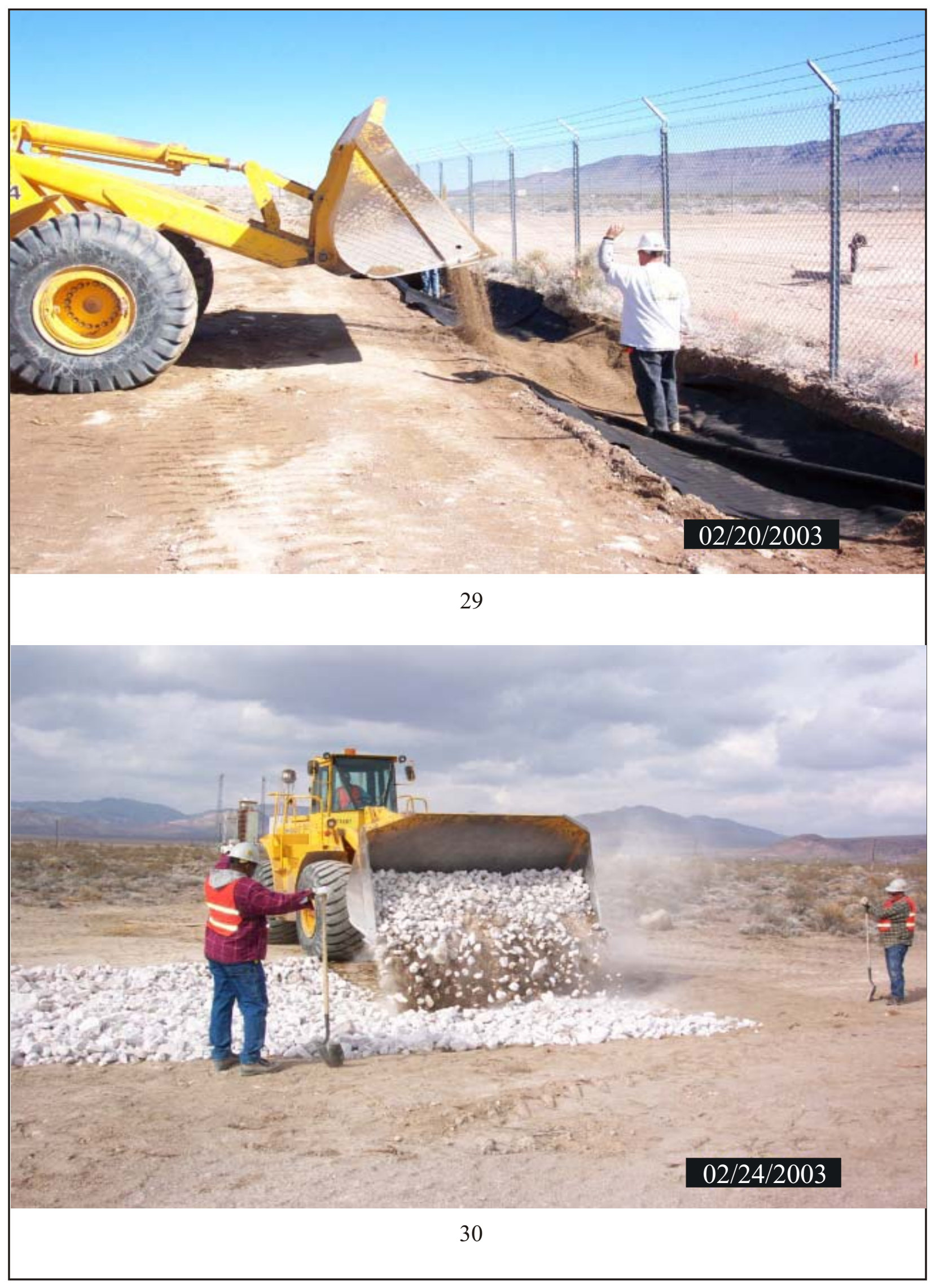


CLOSURE REPORT - CAU 262

Section: Appendix H

Revision: 1

Date: July 2003

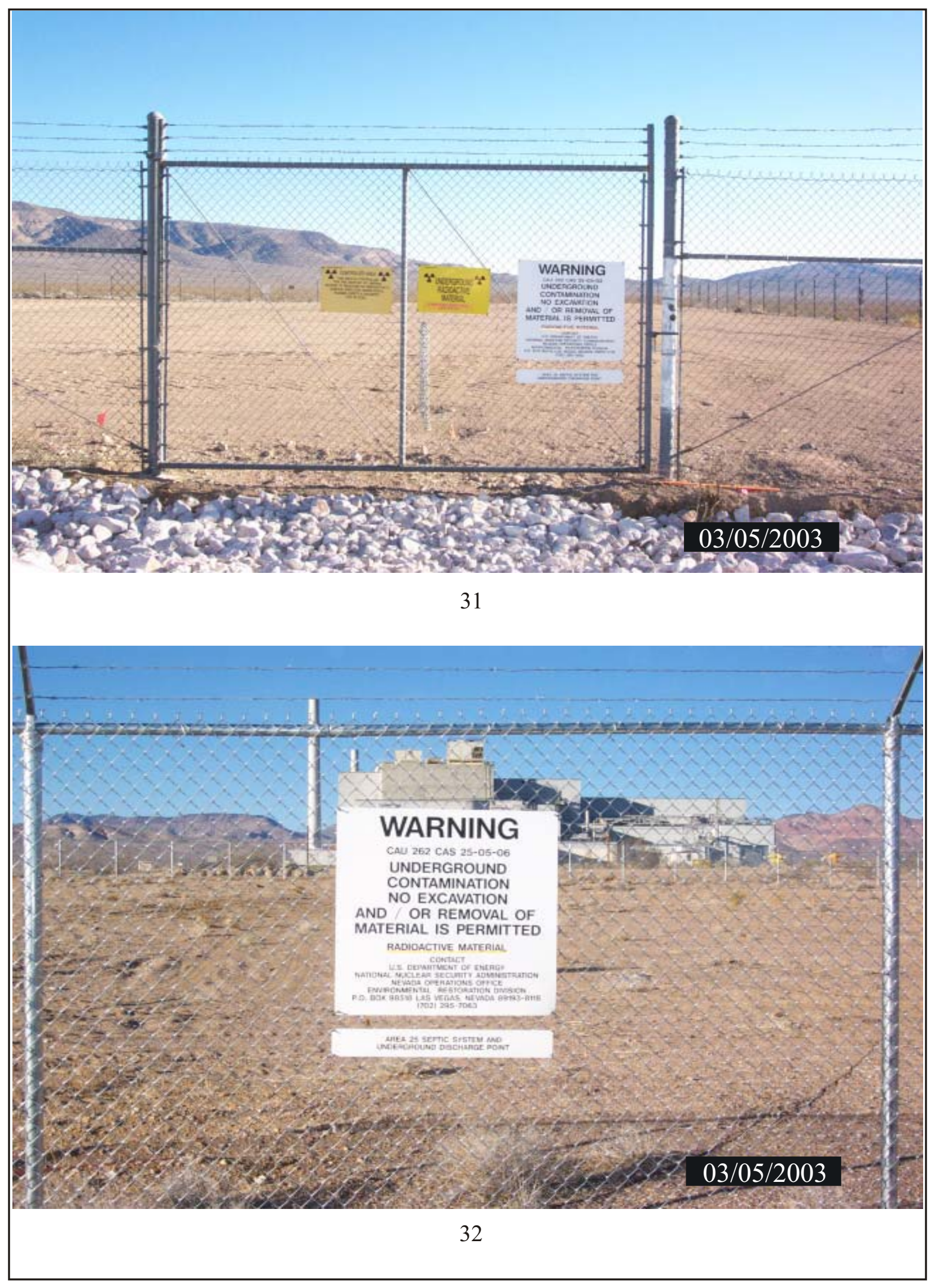


CLOSURE REPORT - CAU 262

Section: Appendix H

Revision: 1

Date: July 2003

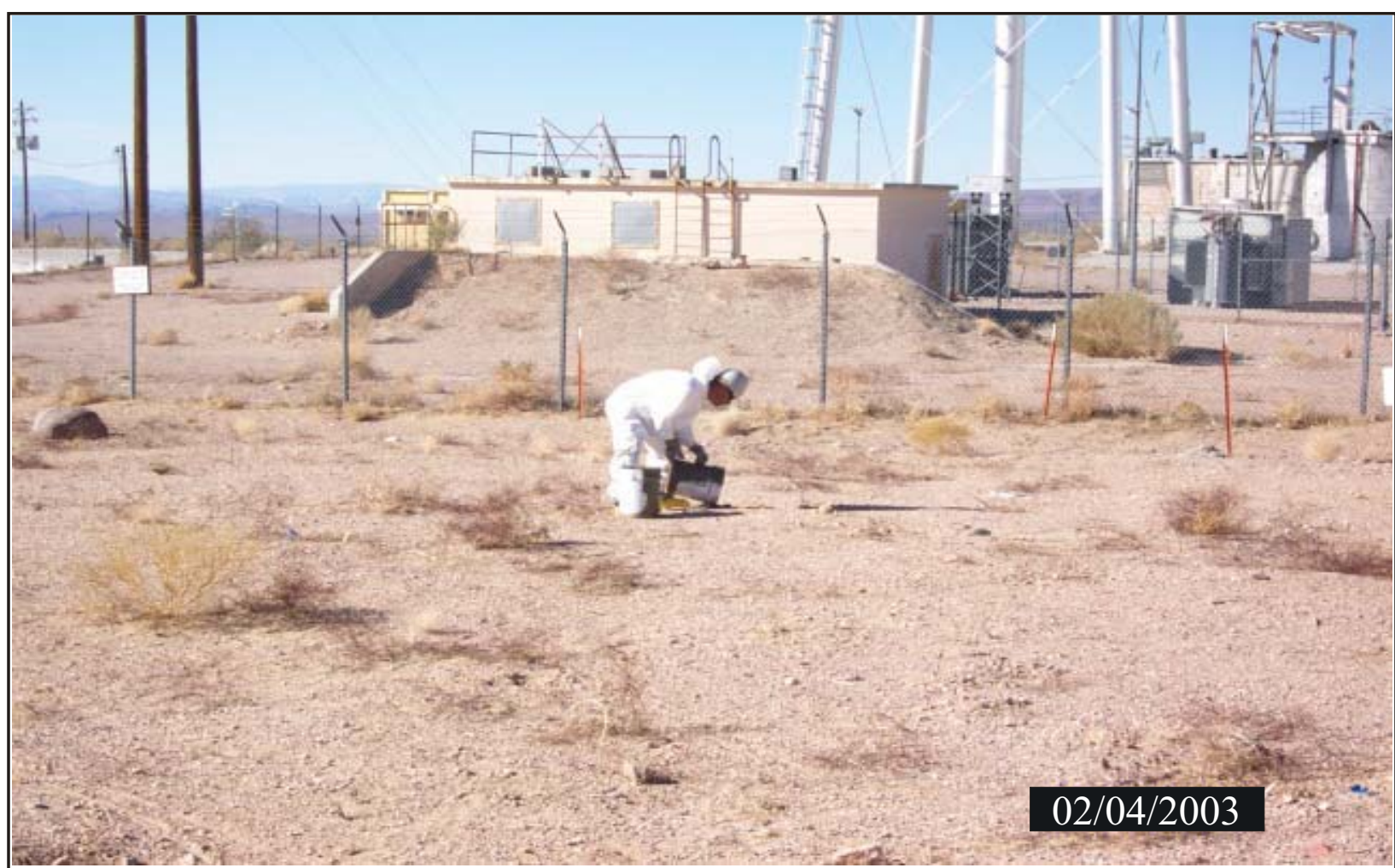

33

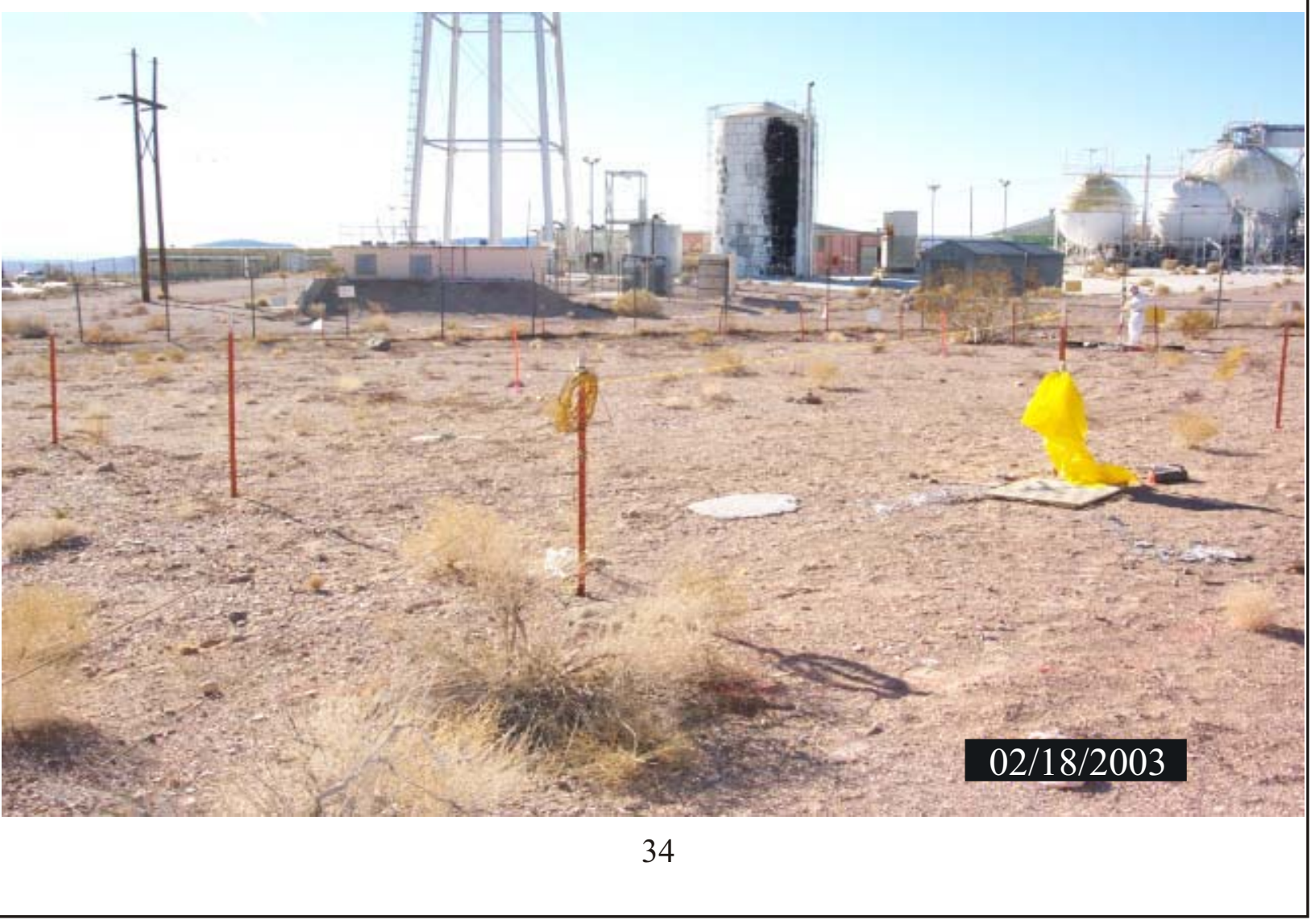


CLOSURE REPORT - CAU 262

Section: Appendix H

Revision: 1

Date: July 2003

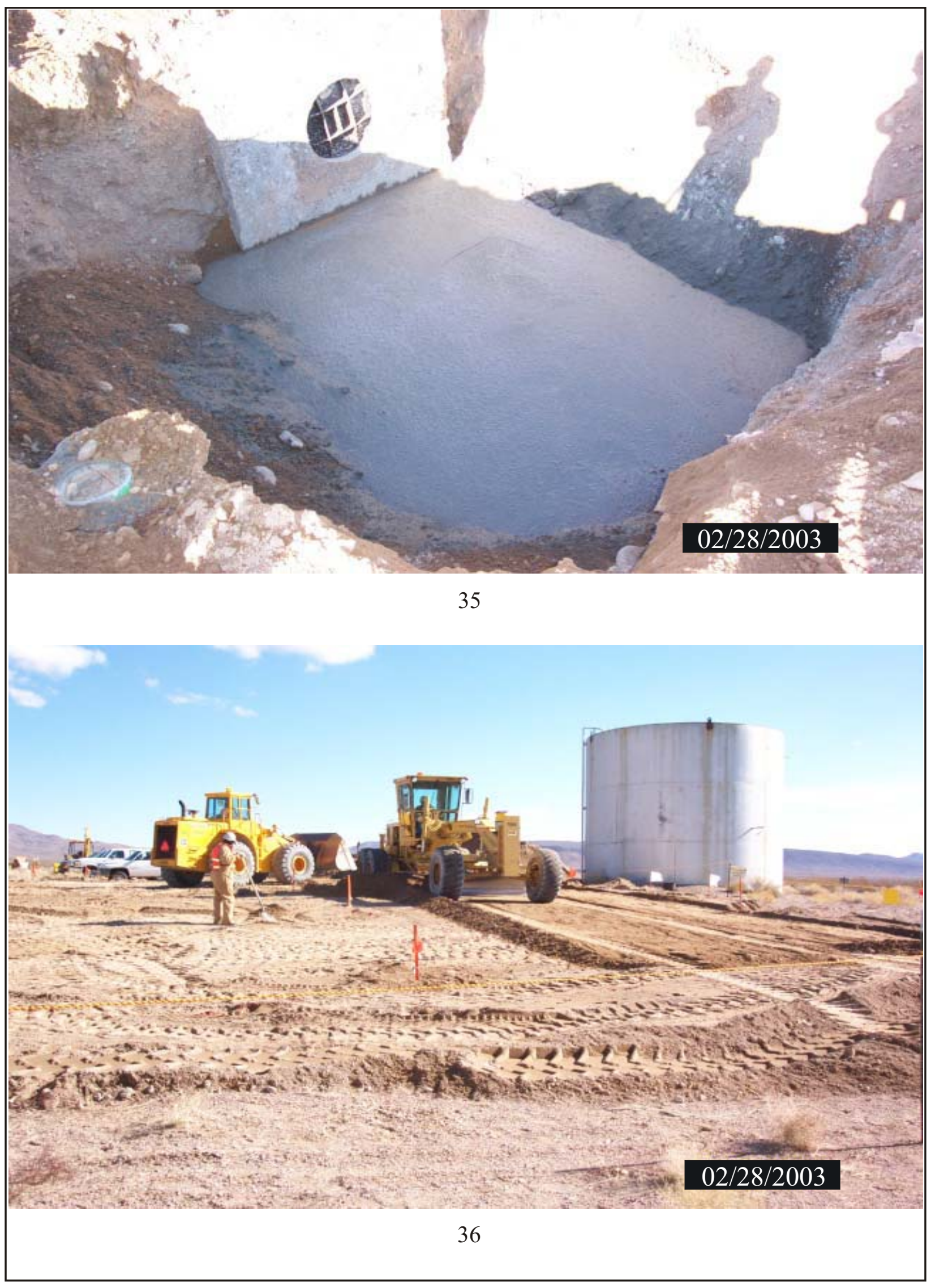


CLOSURE REPORT - CAU 262

Section: Appendix H

Revision: 1

Date: July 2003
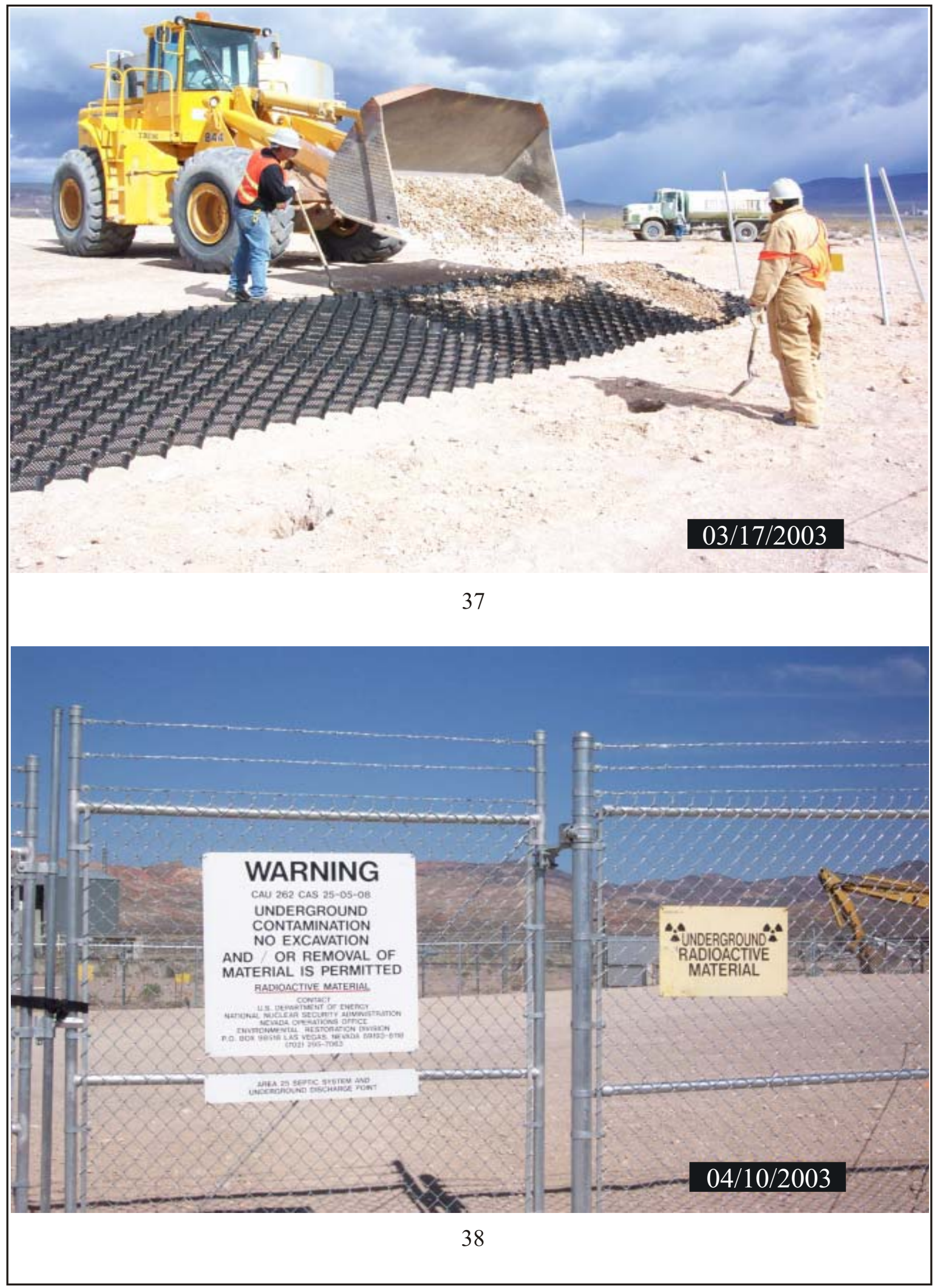
CLOSURE REPORT - CAU 262

Section: Appendix H

Revision: 1

Date: July 2003

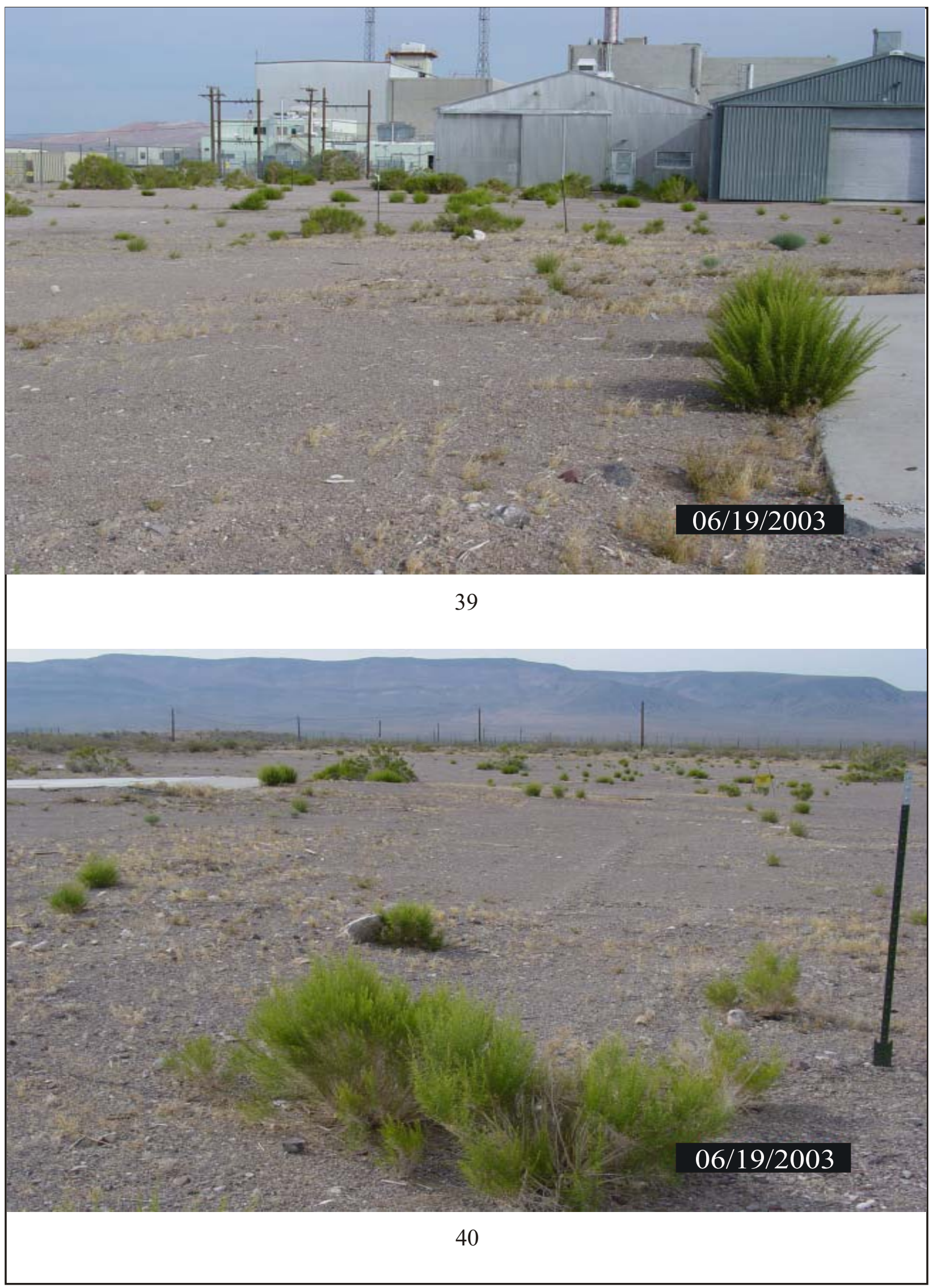




\section{APPENDIX I}

\section{APPROVED RECORDS OF TECHNICAL CHANGE}


CLOSURE RE PORT - CAU 262

Section: Appendix I

Revision : 1

Date: July 2003

THIS PAGE INTENTIONALLY LEFT BLANK 


\section{RECORD OF TECHNICAL CHANGE}

Tochnieal Chrage No, TaboYO2-093

Prolerellob No. CAU:262

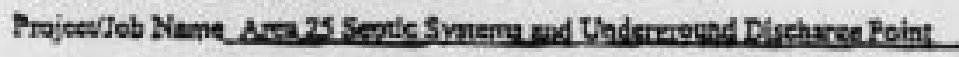

The following technical changes (iacluding fartifieados) aro roquertod by:

Bnd Jackape

(Name)
Tuk Maneat

(Tide)

1. Seetions 2.1.2.2 and 2.1.2.4 of the Corructive Aetion Pla (CAF) discusu the constraction of soll covers over the posted lenchfiolds requiriag a soll eorupaction of $90 \%$ of meximsen denstiy. This requtres densiry

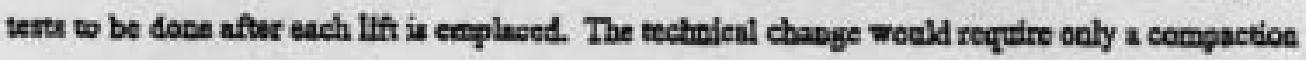
performanece atanderd be doas 10 aceocrpliah $90 \%$ campaction. This ievolves usiag a test plot of backefl matarial and deteconining the mumber of heavy equlpment panses aocastry to soldiove $90 \%$ compaetion. This eliminase the need to perform deativ teats after otab lift is emplacect.

2. Section 2.1.2.2 and Drawing mumber 02052-025-078-C2 in the CAP indieute that Corrective Action Sire 25-05-03 closure frclades the replacement of the oxisting secturty fence. The curreat condition of the exirthg securty feace is weh that replacenent is not pecessary. Orly minor repatrs are required fer the fence to meet specifientioas. Therofore the technleal change in to repeir the existhg fence au aecessany.

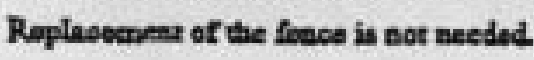

3. Corractivo Aetion Site 25-05-03 elostre (Seetion 2.1.2.2 add Drawing number 02052-025-078-C3 of the

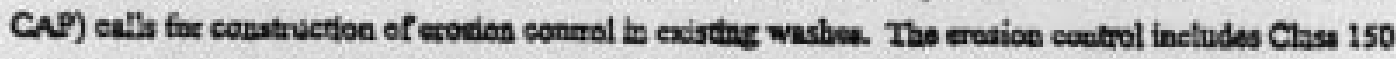

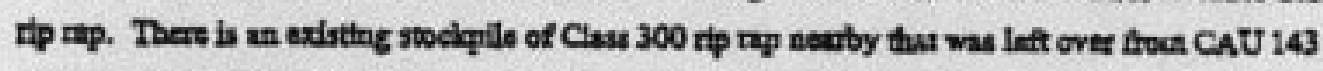
closurn. BN Enginering has approved tho use of the Clase $300 \mathrm{rtp}$ rap inatead of the Class 150 rtp rap.

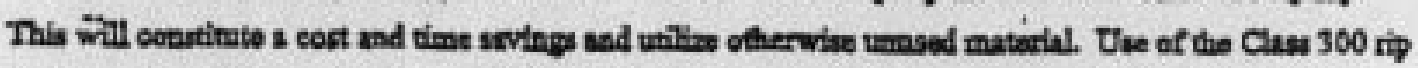

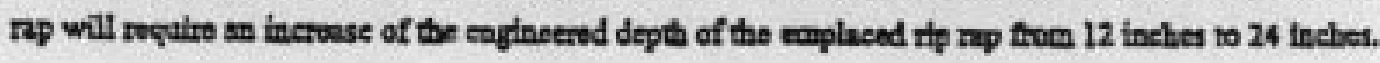

The projoet trane will be Unehanged.

Applieablo Project-Speeine Doramen(a):

Corrective Action Plan for Corroctive Action 262: Area 25 Septic Sysema ad Underyound Diveharge Poimt. Nonda Teut Sire, Nevade DOE/NV-R24 


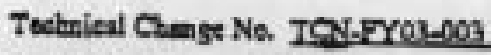

Projed lob No. CAU 35

Pugs 2 of 12

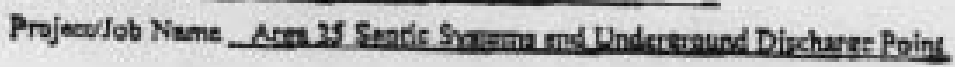

\section{Approved By: Industal Sites Projeet}

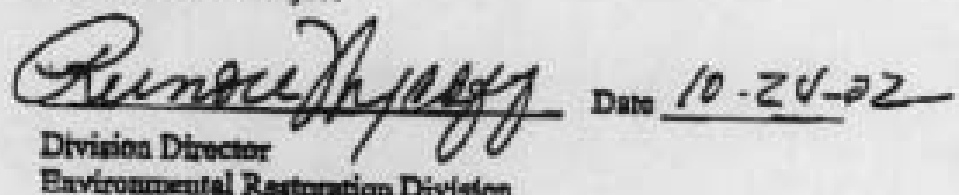

Bnviroumental Rertaration Divisien

Oangel disatyure.

2 aspone

Clemt Nodifiod Yes_- No _ Dato

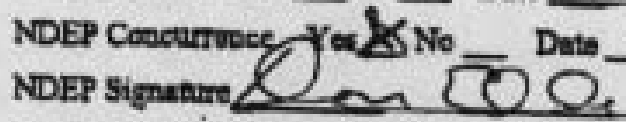
Conterer Chape Onder Ropuired Yes No

3 argane. Coctuat Crange Order No. 


\title{
RECORD OF TECHNICAL CHANGE
}

\author{
Techniad Change Ne. TeN-proz-00s \\ Prejuralob No. cauz252

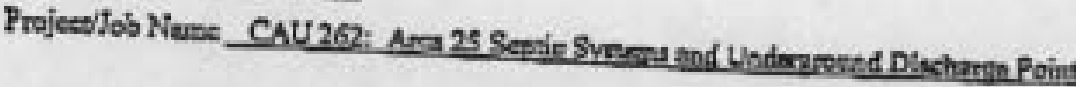

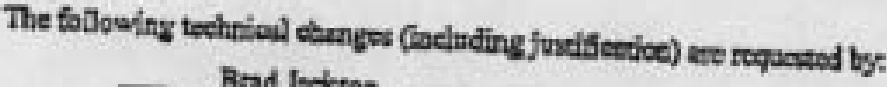
Bind laskstan
Rertusl Nondn Tert Manuger \\ - (Narrot) \\ (nele)
}

Deie 02052003

\section{Technical Change to CAO 262 Corrective Action Plan}

1. pg. 7 / Table 1/ under 25-02-06 replace comment with the followieg

"Liquids in tank will be solidified and the rerneining void space bacicfilled with conerete".

2. Pg. 12 / Section 2.1 .13 / following the second seatence replace the remainder of the

paragraph with the following text:

"The septic tank will be clean closed by opening the tank top to allow

so the contents of the tank can beramoved A we and submitted for laboratory analysis of A waste cheracterizution semple(s) will be collected (IPH-DRO), volatile organic compounds total pearoleum hydrocarbons-diesel runge arganics procedure (U.S. Environmental Protectio (VOCs) by the toxicity chameterization leaching contents will be pumped, a feasible, placed gacy, 1996), and gross alpha/beta. Septic tank fill. Clean fill will be used to solidify any rein a lined basin, and soliditied/absorbed using clean

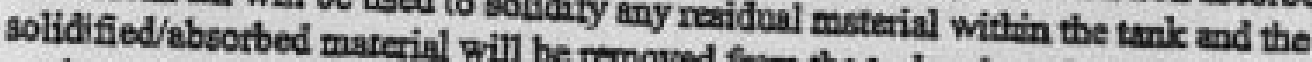
equipment. The tank interior will be removed from the tenk nsing a backoe, or equivaleor removable scele or residual material pressure washed/steam clecued and rinsed to remove eny within the septic tank and analyzed for TPH fin san and gross alle will be collected from clean closure of the tank. If annlyrical Terulte of sean and gross alpha/bota radioactivity to varify contamination in excess of the COC results of the final rinse water indicate residual completed until aceeptable analytical remlon levels, sdditional cleaning sond rinsing will be showing the rinsato is below COC action les are obtained. Upon receipt of analytical results the septic tank will be solidified in place using NNSA will be notified. The rinsate remaining in with coacrete containing Type II Portland Cing clean fill, and the remaining void apace backfilled

All waste removed from the septic tank will remain on site in the lined basin which is a desigaated Waste Accumblation Area (WAA). Waste characterization sumples of the material in the basin will be collected and submitted for gross alpha/beta and gammn radionetivity analysis. After results for the waste chancterization samples are received, the waste will be solidified and by the analytical waste sample results."

\section{parrigraph whth the following text:}

The septio tank will be clean elosed by opening the tank top to allow access to the tank interior so the canterss of the tank cem be removed. A waste charscterization sample(s) will be collected and submitted for laboratory analysis of TPH-DRO and gross alpha/bata. Septic tank contents 
Tochaleal Chenge No. TCN.fYOr-ags

Projec/Job Na. CAU262

Page 2 of 3

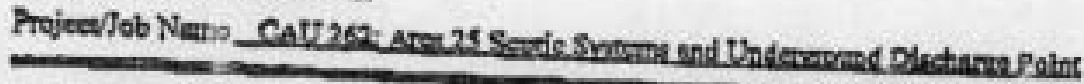

Dare ergnanoma will be pumped, as feasible placed in a lined besin, and solidiffed/absorbed using clean fill. A analyzed, and the waste will be diste material recnoved from the mank will be collected and used to solidify any residul be disposed at an appropriate land disposal unit. Clean fill will be removed from the tank usi material within the tank and the solidified/absorbed material will be pressure washed/gresm using a beckhoe, or equivalent equipinent. The tank interior will be sample of the finsl rines water and rinsed to remove any removable scale or residual material. A full scen to verify clean closure of be collectod from within the septic tank and annlyzed for TPH residual contumination in excess of the $C 0$. If analyticel results of the final rinse water indicate completed until aceeptable analyticel $\mathrm{COC}$ action levals, additional cleaning and rinsing will be showing the rinsare is below $C O C$ sction leve obtainad. Upon receipt of analytical results the septic tapk will be solidified iction levels NNSA will be notified. The rinsate remaining in with concrete containing Type

All waste removed from the septic tank will remain in the lined basin which is a designated WAA. Weste charracterization samples will be collected from the material in the basin and submitted for gross alpha/beta and gamms radioactivity analysis. After results for the waste chancterization samples are received, the waste will be solidified and containerized, if necessary, and transported to an appropriate facility for disposal as determined by the analytical 4. pg. 14 / Section 2.1.2.1 first paragraph / following the third sentence replace
the remalnder of the paragraph with the following text:
"During fleldwork it was determined that the septling

no removable lid is present existing four manholes in the Access to the septlc tank interior will be through the in place by mixing the in the top of the septic tank The tank contents will be solldiffed After adding the coment to the tank with. dry Portland Type II cement, or equivalent. any potential liquids with the sludge and cement paddle will be used to thoroughly mix septic tank will be backfilled with conerete or equivalent."

\section{Jastifilation}

Due to the specifie configurntion of the septic tanks aceess to the tank contents is limited and it is not possible to mix and remove the TPH contaminated liquid and shodge by pumping as originally specified as in the approved CAP. This means that the septic tanils must be opened to
provide access to the cortents for removal, cleaning of the tanks and sampling.

Dry cessent will bo added to the CAS 25.02-06 septio utrik through the existing manholes and mixed with the tank contents. The existing manholes provide sufficient access to the tank interior for solidification of liquid/sludge and backfilling the remaining void space. No removable tari: lid is present, and therefore, there is no lid to remove, survey, and dispose, and 
Toctanical Crange Na, noverrozeope

Projealob No. CAU 26 ?

Page 3 of 3

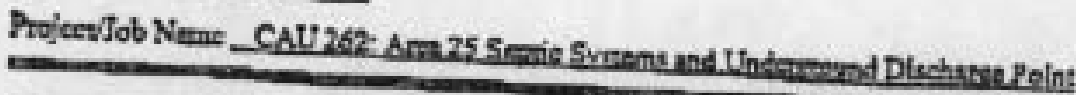

Due nomareos

The project time will be Unchanged.

Applleable Prolect-Specific Document(s): Cor 262: Area 25 Septic Systems and Undersronoctlve Action Plan for Correctlvo Action Nevada. DOE/NV -824
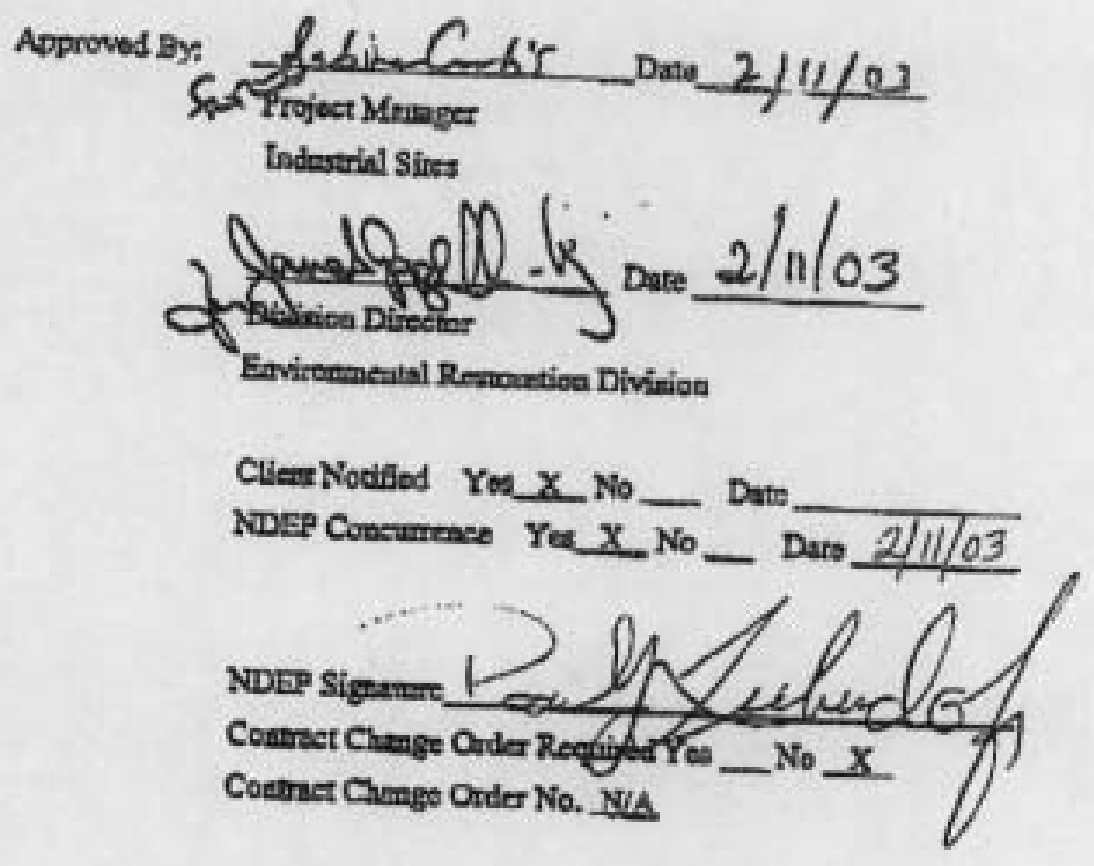
CLOSURE RE PORT - CAU 262

Section: Appendix I

Revision : 1

Date: July 2003

THIS PAGE INTENTIONALLY LEFT BLANK 


\section{APPENDIX J}

\section{"A THROUGH K" EVALUATION*}

* As presented and published in the approved Corrective Action Decision Document for Corrective Action Unit 262: Area 25 Septic Systems and Underground Discharge Point, Nevada Test Site, Nevada, September 2001, NNSA/NV 744, Rev. 1. Las Vegas, NV. 
CLOSURE RE PORT - CAU 262

Section: Appendix J

Revision : 1

Date: July 2003

THIS PAGE INTENTIONALLY LEFT BLANK 


\begin{tabular}{ll} 
ACRONYMS AND ABBREVIATIONS \\
\hline bgs & $\begin{array}{l}\text { Below ground surface } \\
\text { CADD }\end{array}$ \\
Corrective Action Decision Document \\
CAS & Corrective Action Site(s) \\
CAU & Corrective Action Unit(s) \\
COC & Contaminant(s) of concern \\
DOE/NV & U.S. Department of Energy, Nevada Operation Office \\
E-MAD & Engine-Maintenance Assembly and Disassembly \\
ft & Foot (feet) \\
in. & Inch(es) \\
NAC & Nevada Administrative Code \\
NDEP & Nevada Division of Environmental Protection \\
NTS & Nevada Test Site \\
PAL & Preliminary action level(s) \\
PCB & Polychlorinated biphenyl(s) \\
R-MAD & Reactor-Maintenance Assembly and Disassembly \\
SNPO & Space Nuclear Propulsion Office \\
TPH-DRO & Total petroleum hydrocarbons-Diesel range organics \\
USGS & United States Geological Survey
\end{tabular}


CLOSURE RE PORT - CAU 262

Section: Appendix J

Revision : 1

Date: July 2003

THIS PAGE INTENTIONALLY LEFT BLANK 
radionuclides and strontium-90. This will ensure complete removal of contaminated soil with concentrations exceeding PALs.

Contaminated material will be disposed of at an appropriate disposal facility. All excavated areas will be returned to surficial conditions compatible with on-site maintenance operations. Overburden soil along with additional clean fill will be used to backfill the excavations after removal of the contaminated soils. Clean borrow soil will be removed from a nearby location for placement in voids as necessary.

This CAS will be closed in accordance with NAC 445A (NAC, 1998b) as described in this section.

\subsubsection{CAS 25-05-08 (Test Cell C Posted Leachfield)}

Altemative 2 includes excavating and disposing of soil and debris with radionuclide concentrations above PALs or contaminated above free release criteria. This includes the entire leachfield, with additional 15-ft extensions on all four sides from surface grade down to a depth of $17.5 \mathrm{ft}$ bgs. Alternative 2 also includes trenching to remove overburden soil to expose and remove the collection system piping and diversion box, both determined to be radiologically contaminated above free release criteria.

A visual determination will be made to ensure that debris (i.e., piping, diversion box, leachrock) has been removed. Verification soil samples will be collected and analyzed for gamma-emitting radionuclides and strontium-90. This will ensure complete removal of contaminated soil with concentrations exceeding PALs.

Contaminated material will be disposed of at an appropriate disposal facility. All excavated areas will be returned to surficial conditions compatible with on-site maintenance operations. Clean borrow soil will be removed from a nearby location for placement in voids as necessary.

This CAS will be closed in accordance with NAC 445A (NAC, 1998b) as described in this section.

\subsubsection{Alternative 3-Close in Place with Administrative Controls}

Alternative 3 will utilize administrative controls to prevent inadvertent contact with COCs and contaminated media with activity exceeding the free release criteria. These controls would consist of 
use restrictions to minimize access and prevent unauthorized intrusive activities. The future use of the CAU would be restricted from any activity that would alter or modify the containment control unless appropriate concurrence was obtained from NDEP. This alternative does not apply to CASs 25-04-06 A and B, and 25-04-07. Additionally, this alternative does not apply to CAS 25-05-05 because of the potential for mixed waste.

These sites will be closed in accordance with NAC 445A (NAC, 1998b) as described in this section.

\subsubsection{CAS 25-02-06 (E-MAD Complex Leachfield)}

Alternative 3 includes closure in place of the septic tank contents. Free liquids will be solidified. After solidification is completed, the septic tank will be filled with an inert material and a concrete cover will be installed. The concrete cover will be reinforced with wire mesh/rebar. Administrative Controls would consist of use restrictions to prevent unauthorized intrusive activities and impose long-term maintenance requirements for the concrete cover. The future use of the CAS would be restricted from any activity that would alter or modify the containment control unless appropriate concurrence was obtained from NDEP. Additional measures under this alternative include removal of the existing septic tank cover with a backhoe and disposal in an appropriate landfill.

The combination of these measures will effectively prevent inadvertent intrusive activities by humans and native wildlife and mobilization of $\mathrm{COCs}$.

The following evaluation of NAC 445A.227 (2) (a-k) (NAC, 1998b) supports the protection of groundwater from $\mathrm{COC}$ s at this CAS:

a. Depth to groundwater at the nearest well (J-11) is approximately 1,040 $\mathrm{ft}$ bgs (USGS, 1993). This well is located $1.8 \mathrm{mi}$ southeast of E-MAD. Groundwater flow is generally to the southwest and may discharge at Ash Meadows (SNPO, 1970).

b. The distance to the nearest active water-supply well, Well J-12, is approximately 5.1 mi north of E-MAD (DOE/NV, 1996a). Well J-12 is primarily used to provide potable water for Area 25. Groundwater flow is generally to the southwest (Laczniak et al., 1996).

c. No soil is contaminated at this site.

d. Average annual precipitation for valleys in the South-Central Great Basin ranges from 3 to 6 inches (Winograd and Thordarson, 1975). Annual evaporation is roughly 5 to 25 times the 
annual precipitation (Winograd and Thordarson, 1975). The high evaporation and low precipitation rates create a negative water balance for the area; therefore, no driving force associated with precipitation is available to mobilize COCs vertically.

e. PCBs, TPH-DRO, and limited radionuclides are contained within the septic tank.

f. The contaminants are contained within the septic tank.

g. Presently, CAS 25-02-06 is located on a government-controlled facility. The NTS is a restricted area that is guarded on a 24-hour, 365-day per year basis; unauthorized personnel are not admitted to the facility. CAS 25-02-06 is contained within a restricted zone classified as the "Yucca Mountain Site Characterization Zone" (DOE/NV, 1998a) (i.e., non-residential).

h. There are no preferred routes of vertical and lateral migration because septic tank integrity has not been compromised.

i. See Section 2.3.1 for site-specific considerations.

j. The potential for a hazard related to fire, vapor, or explosion is nonexistent for the COCs at the site.

k. No other site-specific factors are known at this time.

Based on this evaluation, impacts to groundwater are not expected. Therefore, groundwater monitoring is not proposed for this site and is not considered an element of the alternatives.

\subsubsection{CAS 25-05-12 (R-MAD Building 3126 Septic System)}

Alternative 3 includes closure in place of the septic tank contents. Free liquids will be solidified. After solidification is completed, the septic tank will be filled with an inert material and a concrete cover will be installed. The concrete cover will be reinforced with wire mesh/rebar. Administrative controls would consist of use restrictions to prevent unauthorized intrusive activities and impose long-term maintenance requirements for the concrete cover. The future use of the CAS would be restricted from any activity that would alter or modify the containment control unless appropriate concurrence was obtained from NDEP. Additional measures under this alternative include removal of the existing septic tank cover with a backhoe and disposal in an appropriate landfill.

The combination of these measures will effectively prevent inadvertent intrusive activities by humans and native wildlife and mobilization of $\mathrm{COCs}$. 
The following evaluation of NAC 445A.227 (2) (a-k) (NAC, 1998b) supports the protection of groundwater from $\mathrm{COC}$ s at this $\mathrm{CAS}$ :

a. Depth to groundwater at the nearest well (J-11) is approximately $1,040 \mathrm{ft}$ bgs (USGS, 1993). This well is located $3.3 \mathrm{mi}$ southwest of R-MAD. Groundwater flow is generally to the southwest and may discharge at Ash Meadows (SNPO, 1970).

b. The distance to the nearest active water-supply well, Well $\mathrm{J}-12$, is approximately $7 \mathrm{mi}$ northwest of R-MAD (DOE/NV, 1996a). Well J-12 is primarily used to provide potable water for Area 25. Groundwater flow is generally to the southwest (Laczniak et al., 1996).

c. No soil is contaminated at this site.

d. Average annual precipitation for valleys in the South-Central Great Basin ranges from 3 to 6 inches (Winograd and Thordarson, 1975). Annual evaporation is roughly 5 to 25 times the annual precipitation (Winograd and Thordarson, 1975). The high evaporation and low precipitation rates create a negative water balance for the area; therefore, no driving force associated with precipitation is available to mobilize COCs vertically.

e. TPH-DRO and limited radionuclides are contained within the septic tank.

f. The contaminants are contained within the septic tank.

g. Presently, CAS 25-05-12 is located on a govemment-controlled facility. The NTS is a restricted area that is guarded on a 24-hour, 365-day per year basis; unauthorized personnel are not admitted to the facility. CAS 25-05-12 is contained within a restricted zone classified as a "Research Test and Experiment Zone." This zone is designated for small-scale research and development projects and demonstrations; pilot projects; outdoor tests; and experiments for development, quality assurance, or reliability of material and equipment under controlled conditions. This includes compatible nondefense research, development and testing projects, and activities (DOE/NV, 1998a).

h. There are no preferred routes of vertical and lateral migration because septic tank integrity has not been compromised.

i. See Section 2.3.6 for site-specific considerations.

j. The potential for a hazard related to fire, vapor, or explosion is nonexistent for the COCs at the site.

k. No other site-specific factors are known at this time. 
Based on this evaluation, impacts to groundwater are not expected. Therefore, groundwater monitoring is not proposed for this site and is not considered an element of the altematives.

\subsubsection{CAS 25-05-03 (R-MAD Posted Leachfield)}

Altemative 3 includes an engineered surface cap that will be constructed over the leachfield footprint and extended to the boundaries of the currently fenced area. Administrative controls will be implemented to restrict inadvertent contact with contaminated media within the leachfield and collection system piping. Administrative controls would consist of use restrictions to prevent unauthorized intrusive activities and impose long-term maintenance requirements for the surface cap. The future use of the CAS would be restricted from any activity that would alter or modify the containment control unless appropriate concurrence was obtained from NDEP.

The combination of these measures will effectively prevent inadvertent intrusive activities by humans and native wildlife and mobilization of COCs.

Additional measures under this alternative include grouting the distribution box and the monitoring tubes to the ground surface; and backfilling voids at the site which includes installed subsurface features consisting of three large vaults, the 55-gallon diversion drum, and the two valve boxes. Redirecting surface water run-on may be required to prevent localized flooding from impacting the surface cap.

The following evaluation of NAC 445A.227 (2) (a-k) (NAC, 1998b) supports the protection of groundwater from $\mathrm{COCs}$ at this CAS:

a. Depth to groundwater at the nearest well (J-11) is approximately $1,040 \mathrm{ft}$ bgs (USGS, 1993). This well is located $3.3 \mathrm{mi}$ southwest of R-MAD. Groundwater flow is generally to the southwest and may discharge at Ash Meadows (SNPO, 1970). Field screening and analytical data indicate that COCs are confined to the leachfield footprint primarily 0 to $10 \mathrm{ft}$ below the base of the leachfield. This indicates minimal vertical migration has occurred in the past and, with the removal of man-made driving forces, vertical migration will be negligible in the future.

b. The distance to the nearest active water-supply well, Well $\mathrm{J}-12$, is approximately $7 \mathrm{mi}$ northwest of R-MAD (DOE/NV, 1996a). Well J-12 is primarily used to provide potable water for Area 25. Groundwater flow is generally to the southwest (Laczniak et al, 1996). 
c. The soil beneath the leachrock was a poorly sorted, silty-gravelly sand with abundant pebbles, some gravel, and a few cobbles. Geotechnical data were collected and the results are included in Appendix F of this CADD.

d. Average annual precipitation for valleys in the South-Central Great Basin ranges from 3 to 6 inches (Winograd and Thordarson, 1975). Annual evaporation is roughly 5 to 25 times the annual precipitation (Winograd and Thordarson, 1975). The high evaporation and low precipitation rates create a negative water balance for the area; therefore, no driving force associated with precipitation is available to mobilize COCs vertically.

c. The types of regulated substances released are arsenic, PCBs, TPH-DRO, and limited radionuclides. Downward migration of $\mathrm{COCs}$ is slowed by the following parameters:

- Volume of release - it is assumed that small volumes of COCs were released over a long period of time rather than a large volume over a short duration.

- Soil saturation - the soil tends to be very dry, especially near the surface and below the leachfield where the COCs are concentrated.

- Soil particle adsorption/desorption - PCB, petroleum hydrocarbons, and radionuclides tend to adsorb to the soil particles with little desorption as suggested by the limited vertical migration of COCs.

f. The lateral extent of contamination is defined by the leachfield boundaries based on reduced concentrations and the lack of contamination found in nearby sampling locations demonstrating minimal lateral mobility. Contaminant concentrations below the upper sampling horizons were significantly lower, demonstrating minimal vertical migration. The vertical extent of contamination is confined to $10 \mathrm{ft}$ below the diversion drum ( $16 \mathrm{ft}$ bgs) and 0 to $10 \mathrm{ft}$ below the base of the leachfield based on field screening and analytical data.

g. Presently, CAS $25-05-03$ is located on a government-controlled facility. The NTS is a restricted area that is guarded on a 24-hour, 365-day-per-year basis; unauthorized personnel are not admitted to the facility. CAS $25-05-03$ is contained within a restricted use zone classified as a "Research Test and Experiment Zone." This zone is designated for small-scale research and development projects and demonstrations; pilot projects; outdoor tests; and experiments for development, quality assurance, or reliability of material and equipment under controlled conditions. This includes compatible nondefense research, development and testing projects, and activities (DOE/NV, 1998a).

h. Preferred routes of vertical and lateral migration are nonexistent since the sources have been eliminated and driving forces are not viable.

i. See Section 2.3.8 for site-specific considerations. 
j. The potential for a hazard related to fire, vapor, or explosion is nonexistent for the COCs at the site.

k. No other site-specific factors are known at this time.

Based on this evaluation, impacts to groundwater are not expected. Therefore, groundwater monitoring is not proposed for this site and is not considered an element of the altermatives.

\subsubsection{CAS 25-05-06 (E-MAD Posted Leachfield)}

Under Alternative 3, administrative controls will be implemented to restrict inadvertent contact with subsurface contaminated media within the leachfield and collection system piping. Administrative controls would consist of use restrictions to prevent unauthorized intrusive activities. The future use of the CAS would be restricted from any activity that would alter or modify the containment control unless appropriate concurrence was obtained from NDEP.

Additional measures under this alternative include grouting the distribution box; cutting and grouting the monitoring tubes to the ground surface; and replacing the current leachfield fence with security fencing and appropriate signage. The remaining debris (monitoring tube sections and fencing) will be disposed of in an appropriate disposal facility.

The following evaluation of NAC 445A.227 (2) (a-k) (NAC, 1998b) supports the protection of groundwater from COCs at this CAS:

a. Depth to groundwater at the nearest well (J-11) is approximately 1,040 $\mathrm{ft}$ bgs (USGS, 1993). This well is located $1.8 \mathrm{mi}$ southeast of E-MAD. Groundwater flow is generally to the southwest and may discharge at Ash Meadows (SNPO, 1970). Field screening and analytical data indicate that COCs are confined primarily within 0 to $8.8 \mathrm{ft}$ below the base of the leachfield. This indicates minimal vertical migration has oceurred in the past and, with the removal of man-made driving forces, vertical migration will be negligible in the future.

b. The distance to the nearest active water-supply well, Well $\mathrm{J}-12$, is approximately 5.1 mi north of E-MAD (DOE/NV, 1996a). Well J-12 is primarily used to provide potable water for Area 25. Groundwater flow is generally to the southwest (Laczniak et al., 1996).

c. Lenses of sand and silt were present at some locations. The soil beneath the leachrock was a moderately sorted, silty sand with some gravel, and a few cobbles. Geotechnical data were collected and the results are included in Appendix F of this CADD. 
d. Average annual precipitation for valleys in the South-Central Great Basin ranges from 3 to 6 inches (Winograd and Thordarson, 1975). Annual evaporation is roughly 5 to 25 times the annual precipitation (Winograd and Thordarson, 1975). The high evaporation and low precipitation rates create a negative water balance for the area; therefore, no driving force associated with precipitation is available to mobilize COCs vertically.

e. The types of regulated substances released are radionuclides. Downward migration of COCs is slowed by the following parameters:

- Volume of release - it is assumed that small volumes of COCs were released over a long period of time rather than a large volume over a short duration.

- Soil saturation - the soil tends to be very dry, especially near the surface and below the leachfield where the COCs are concentrated.

- Soil particle adsorption/desorption - radionuclides tend to adsorb to the soil particles with little desorption as suggested by the limited vertical migration of COCs.

f. The lateral extent of contamination is defined by the leachfield boundaries based on reduced concentrations and the lack of contamination found in nearby sampling locations demonstrating minimal lateral mobility. Contaminant concentrations below the upper sampling horizons were significantly lower, demonstrating minimal vertical migration. The vertical extent of contamination is primarily confined to 0 to $8.8 \mathrm{ft}$ below the base of the leachfield based on field screening and analytical data.

g. Presently, CAS 25-05-06 is located on a government-controlled facility. The NTS is a restricted area that is guarded on a 24-hour, 365-day per year basis; unauthorized personnel are not admitted to the facility. CAS $25-05-06$ is contained within a restricted zone classified as the "Yucca Mountain Site Characterization Zone" (DOE/NV, 1998a) (i.e., non-residential).

h. Preferred routes of vertical and lateral migration are nonexistent since the sources have been eliminated and driving forces are not viable.

i. See Section 2.3.9 for site-specific considerations.

j. The potential for a hazard related to fire, vapor, or explosion is nonexistent for the COCs at the site.

k. No other site-specific factors are known at this time.

Based on this evaluation, impacts to groundwater are not expected. Therefore, groundwater monitoring is not proposed for this site and is not considered an element of the alternatives. 


\subsubsection{CAS 25-05-08 (Test Cell C Posted Leachfield)}

Altermative 3 includes an engineered surface cap that will be constructed over the leachfield footprint and extended $15 \mathrm{ft}$ in the horizontal dimensions. Administrative controls will be implemented to restrict inadvertent contact with contaminated media within the leachfield and collection system piping. Administrative controls would consist of use restrictions to prevent unauthorized intrusive activities and impose long-term maintenance requirements for the surface cap. The future use of the CAS would be restricted from any activity that would alter or modify the containment control unless appropriate concurrence was obtained from NDEP.

The combination of these measures will effectively prevent inadvertent intrusive activities by humans and native wildlife and mobilization of COCs.

Additional measures under this altemative include grouting the distribution box and the monitoring tubes to the ground surface; and replacing the current leachfield fence with security fencing and appropriate signage. The remaining fencing will be disposed of in an appropriate disposal facility. Redirecting surface water run-on may be required to prevent localized flooding from impacting the surface cap.

The following evaluation of NAC 445A.227 (2) (a-k) (NAC, 1998b) supports the protection of groundwater from $\mathrm{COCs}$ at this CAS:

a. Depth to groundwater at the nearest well (J-11) is approximately 1,040 $\mathrm{ft}$ bgs (USGS, 1993). This well is located $3 \mathrm{mi}$ southwest of Test Cell C. Groundwater flow is generally to the southwest and may discharge at Ash Meadows (SNPO, 1970). Field screening and analytical data indicate that COCs are confined primarily to within 0 to $10 \mathrm{ft}$ below the base of the leachfield. This indicates minimal vertical migration has occurred in the past and, with the removal of man-made driving forces, vertical migration will be negligible in the future.

b. The distance to the nearest active water-supply well, Well $\mathrm{J}-12$, is approximately $4.7 \mathrm{mi}$ northwest of Test Cell C (DOE/NV, 1996a). Well J-12 is primarily used to provide potable water for Area 25. Groundwater flow is generally to the southwest (Laczniak et al., 1996).

c. The soil beneath the leachrock was a poorly sorted, silty-gravelly sand with abundant pebbles, some gravel, and a few cobbles. Geotechnical data were collected and the results are included in Appendix F of this CADD. 
d. Average annual precipitation for valleys in the South-Central Great Basin ranges from 3 to 6 inches (Winograd and Thordarson, 1975). Annual evaporation is roughly 5 to 25 times the annual precipitation (Winograd and Thordarson, 1975). The high evaporation and low precipitation rates create a negative water balance for the area; therefore, no driving force associated with precipitation is available to mobilize COCs vertically.

e. The types of regulated substances released are radionuclides. Downward migration of COCs is slowed by the following parameters:

- Volume of release - it is assumed that small volumes of COCs were released over a long period of time rather than a large volume over a short duration.

- Soil saturation - the soil tends to be very dry, especially near the surface and below the leachfield where the COCs are concentrated.

- Soil particle adsorption/desorption - radionuclides tend to adsorb to the soil particles with little desorption as suggested by the limited vertical migration of $\mathrm{COCs}$.

f. The lateral extent of contamination is defined by the leachfield boundaries based on reduced concentrations and the lack of contamination found in nearby sampling locations demonstrating minimal lateral mobility. Contaminant concentrations below the upper sampling horizons were significantly lower, demonstrating minimal vertical migration. The vertical extent of contamination is primarily confined to within 0 to $10 \mathrm{ft}$ below the base of the leachfield based on field screening and analytical data.

g. Presently, CAS 25-05-08 is located on a government-controlled facility. The NTS is a restricted area that is guarded on a 24-hour, 365-day per year basis; unauthorized personnel are not admitted to the facility. CAS 25-05-08 is contained within a restricted use zone classified as a "Research Test and Experiment Zone," This zone is designated for small-scale research and development projects and demonstrations; pilot projects; outdoor tests; and experiments for development, quality assurance, or reliability of material and equipment under controlled conditions. This includes compatible nondefense research, development and testing projects, and activities (DOE/NV, 1998a).

h. Preferred routes of vertical and lateral migration are nonexistent since the sources have been eliminated and driving forces are not viable.

i. See Section 2.3.10 for site-specific considerations.

j. The potential for a hazard related to fire, vapor, or explosion is nonexistent for the COCs at the site.

k. No other site-specific factors are known at this time. 
Based on this evaluation, impacts to groundwater are not expected. Therefore, groundwater monitoring is not proposed for this site and is not considered an element of the alternatives.

\subsection{Evaluation and Comparison of Alternatives}

Because NAC 444.818 (NAC, 1999) requires removal of septic tank contents, only Alternative 2 applies to CASs 25-04-06 A and B, and 25-04-07; therefore, an evaluation and comparison of alternatives is not required for these CASs. Only Alternative 2 applies to CAS 25-05-05 because the potential for mixed waste cannot be excluded until the contents are homogenized for removal and subsequent sampling.

The general corrective action standards and remedy selection decision factors described in Section 3.2 were used to conduct detailed and comparative analyses of each corrective action alternative. The advantages and disadvantages of each alternative were assessed to select preferred alternatives for CAU 262. Tables 3-1,3-3,3-5, and 3-7 present a summary of the detailed analysis of the alternatives for CASs 25-02-06, 25-05-12, 25-05-03, 25-05-06, and 25-05-08. Tables 3-2, 3-4, 3-6, and $3-8$ present the comparative analysis of the alternatives for the same CASs. Cost summaries are provided in Appendix C. 


\section{REFERENCES}

DOE/NV, see U.S. Department of Energy, Nevada Operations Office

Laczniak, R.J., J.C. Cole, D.A. Sawyer, and D.T. Trudeau. 1996. Summary of Hydrogeological Controls on Ground-Water Flow at the Nevada Test Site, Nye County, Nevada, U.S. Geological Survey Water-Resources Investigations Report 96-4109. Denver, CO: U.S Geological Survey.

NAC, see Nevada Administrative Code

Nevada Administrative Code. 1998b. NAC 445A, "Water Controls. Carson City, NV.

SNPO, see Space Nuclear Propulsion Office

Space Nuclear Propulsion Office. 1970. NRDS Master Plan 1969-1970, Nuclear Rocket Development Station, Jackass Flats, Nevada. Las Vegas, NV.

U.S. Department of Energy, Nevada Operations Office. 1996a. Final Environmental Impact Statement for the Nevada Test Site and Off-Site Locations in the State of Nevada, DOE/EIS 0243. Las Vegas, NV.

U.S. Department of Energy, Nevada Operations Office. 1998a. Nevada Test Site Resource Management Plan, DOE/NV 518. Las Vegas, NV.

USGS, see U.S. Geological Survey

U.S. Geological Survey. 1993. Selected Ground-Water Data for yucca Mountain Region, Southern Nevada and Eastern California, Calendar Year 1993, Open-File report 95-158.

Winograd, I.J., and W. Thordarson. 1975. Hydrologic and Hydrochemical Framework, SouthCentral Great Basin, Nevada-California, with Special Reference to the Nevada Test Site, U.S. Geological Survey Professional Paper 712C. Washington, DC: U.S. Government Printing Office. 


\section{APPENDIX K}

\section{NEVADA DIVISION OF ENVIRONMENTAL PROTECTION DOCUMENT REVIEW SHEET}


CLOSURE RE PORT - CAU 262

Section: Appendix K

Revision : 1

Date: July 2003

THIS PAGE INTENTIONALLY LEFT BLANK 
$\frac{3}{8}$

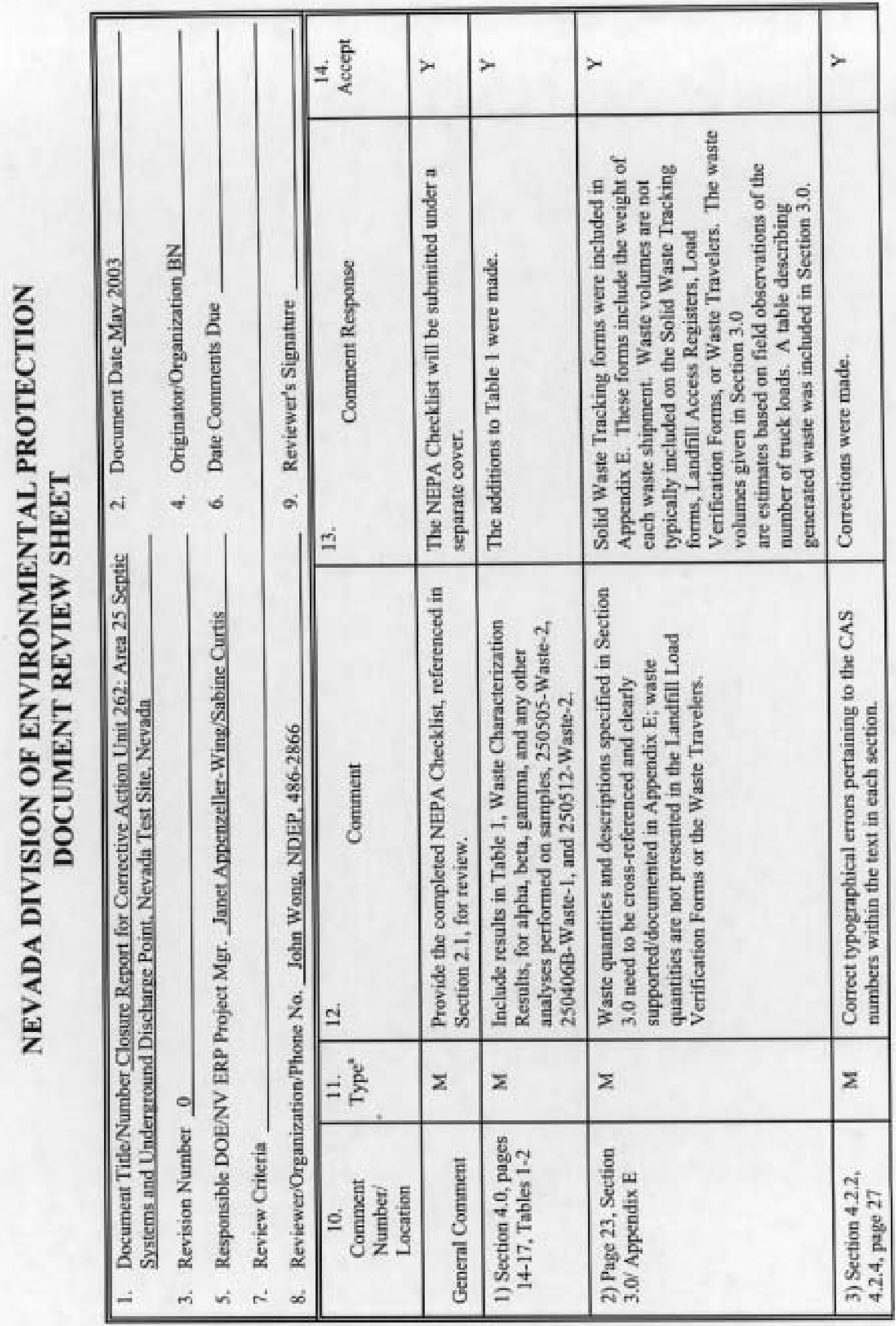




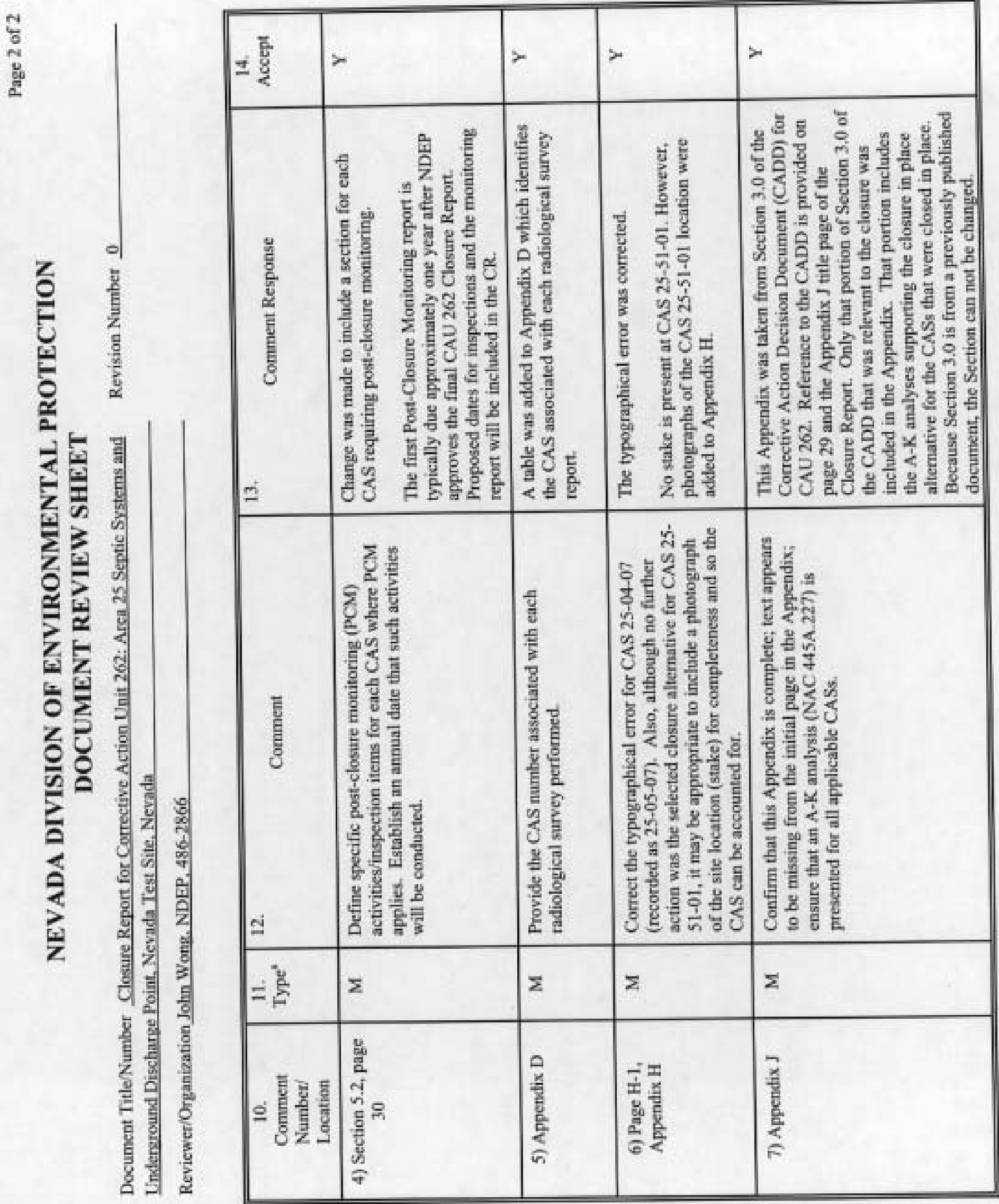


CLOSURE RE PORT - CAU 262

Section: Distribution List

Revision : 1

Date: July 2003

\section{DISTRIBUTION LIST}


CLOSURE RE PORT - CAU 262

Section: Distribution List

Revision : 1

Date: July 2003

THIS PAGE INTENTIONALLY LEFT BLANK 


\section{DISTRIBUTION LIST}

*Provide copy of initial distribution of all revisions; others receive NDEP-approved revision only.

\section{$\underline{\text { Nevada Department of Environmental Protection }}$}

Paul Liebendorfer

1 (Controlled)*

Bureau of Federal Facilities

Division of Environmental Protection

333 W. Nye Lane, Room 138

Carson City, NV 89706-0866

Donald Elle

Bureau of Federal Facilities

1 (Controlled)*

Division of Environmental Protection

1771 E. Flamingo Road, Suite 121-A

Las Vegas, NV 89119-0837

\section{U.S. Department of Energy}

Janet Appenzeller-Wing

1 (Uncontrolled)*

Environmental Restoration Division

U.S. Department of Energy

National Nuclear Security Administration

Nevada Site Office

P.O. Box 98518, M/S 505

Las Vegas, NV 89193-8518

Sabine Curtis

Environmental Restoration Division

1 (Uncontrolled)*

U.S. Department of Energy

National Nuclear Security Administration

Nevada Site Office

P.O. Box 98518, M/S 505

Las Vegas, NV 89193-8518

Sabrina Lawrence

1 (Controlled)*

Environmental Restoration Division

U.S. Department of Energy

National Nuclear Security Administration

Nevada Site Office

P.O. Box 98518, M/S 505

Las Vegas, NV 89193-8518 


\section{DISTRIBUTION LIST (continued)}

\section{U.S. Department of Energy (continued)}

U.S. Department of Energy

National Nuclear Security Administration

Nevada Site Office

Public Reading Facility

P.O. Box 98521, M/S CF040

Las Vegas, NV 89193-8521

U.S. Department of Energy

National Nuclear Security Administration

Nevada Site Office

Technical Library

P.O. Box 98518, M/S 505

Las Vegas, NV 89193-8518

U.S. Department of Energy

Office of Scientific and Technical Information

P.O. Box 62

Oak Ridge, TN 37831-0062

\section{Bechtel Nevada}

Correspondence Control

Bechtel Nevada

P.O. Box 98521, M/S CF008

Las Vegas, NV 89193-8521

Environmental Management Library

Bechtel Nevada

P.O. Box 98521, M/S NLV080

Las Vegas, NV 89193-8521

Tom Fitzmaurice

Bechtel Nevada

P.O. Box 98521, M/S NTS306

Las Vegas, NV 89193-8521

Brad Jackson

Bechtel Nevada

P.O. Box 98521, M/S NTS306

Las Vegas, NV 89193-8521
1 (Controlled) \&

1 (Uncontrolled)

1 (Uncontrolled) 


\section{DISTRIBUTION LIST (continued)}

\section{$\underline{\text { Bechtel Nevada (continued) }}$}

Wayne Johnson

1 (Uncontrolled)*

Bechtel Nevada

P.O. Box 98521, M/S NLV080

Las Vegas, NV 89193-8521

Steve Nacht

1 (Uncontrolled)*

Bechtel Nevada

P.O. Box 98521, M/S NTS306

Las Vegas, NV 89193-8521

Dan Tobiason

1 (Uncontrolled)*

Bechtel Nevada

P.O. Box 98521, M/S NTS306

Las Vegas, NV 89193-8521

\section{$\underline{\text { Shaw Environmental Incorporated }}$}

FFACO Coordinator

1 (Controlled)

Shaw Inc.

P.O. Box 93838, M/S 439

Las Vegas, NV 89193-8521

John Stokowski

1 (Uncontrolled)*

Shaw Inc.

P.O. Box 93838, M/S 439

Las Vegas, NV 89193-8521

\section{$\underline{\text { State of Nevada }}$}

Manager, Northern Nevada

1 (Uncontrolled)

FFACO Public Reading Facility

Nevada State Library and Archives Federal Publications

100 North Stewart Street

Carson City, NV 89701-4285 
CLOSURE RE PORT - CAU 262

Section: Distribution List

Revision : 1

Date: July 2003

THIS PAGE INTENTIONALLY LEFT BLANK 